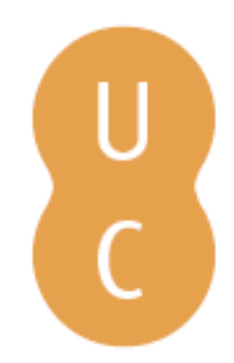

\title{
pommalina
}

\section{A recepção dos clássicos em Portugal e no Brasil}

Autor(es): $\quad$ Silva, Maria de Fátima Sousa e; Augusto, Maria das Graças de Moraes

Publicado por: Imprensa da Universidade de Coimbra

URL

persistente: URI:http://hdl.handle.net/10316.2/37035

DOI: $\quad$ DOI:http://dx.doi.org/10.14195/978-989-26-1043-6

Accessed : $\quad$ 26-Apr-2023 12:45:14

A navegação consulta e descarregamento dos títulos inseridos nas Bibliotecas Digitais UC Digitalis, UC Pombalina e UC Impactum, pressupõem a aceitação plena e sem reservas dos Termos e Condições de Uso destas Bibliotecas Digitais, disponíveis em https://digitalis.uc.pt/pt-pt/termos.

Conforme exposto nos referidos Termos e Condições de Uso, o descarregamento de títulos de acesso restrito requer uma licença válida de autorização devendo o utilizador aceder ao(s) documento(s) a partir de um endereço de IP da instituição detentora da supramencionada licença.

Ao utilizador é apenas permitido o descarregamento para uso pessoal, pelo que o emprego do(s) título(s) descarregado(s) para outro fim, designadamente comercial, carece de autorização do respetivo autor ou editor da obra.

Na medida em que todas as obras da UC Digitalis se encontram protegidas pelo Código do Direito de Autor e Direitos Conexos e demais legislação aplicável, toda a cópia, parcial ou total, deste documento, nos casos em que é legalmente admitida, deverá conter ou fazer-se acompanhar por este aviso. 
politica no Brasil do sécu

Categorias aristotélicas por Silvestre Pinheiro Ferreira - Musas errantes: tesouros da Antiguidade Clássica no labirinto da Biblioteca Nacional Brasileira - Eudoro de Sousa e a Mitologia • Câmara Cascudo em defesa de Epicuro - Medéia carioca - Ecos de Platão em Vergílio Ferreira - Imaginário clássico na poesia de António Arnaut - Motivos clássicos na poesia novilatina em Portugal: Manuel da Costa - Uma Ifigénia portuguesa: "Noite escura" de João Canijo • Uma leitura de Mau Tempo no Canal de Vitorino Nemésio $\bullet A$ phýsis grega e o Brasil: as viagens de Von Martius $\bullet$ Fantasia para dois coronéis e uma piscina. Ecos clássicos num contexto do séc. XX

\section{A RECEPÇÃO DOS CLÁSSICOS EM PORTUGAL E NO BRASIL}

Maria de Fátima Silva Maria das Graças de Moraes Augusto COORDENAÇÃo 


\section{SÉRIE MITO E (RE)ESCRITA}

ISSN: $2182-8814$

\section{PERIODICIDADE: Anual}

Apresentação: Poetas, pintores, escultores, na Antiguidade, familiarizados com mitos antigos de deuses e de homens, que cristalizavam experiências, interrogaçóes, respostas quanto à existência do homem no tempo e no mundo, em mitos se inspiraram, em contínua criação-recriaçẩo, para neles verterem a sua própria experiência temporal, com todos os desassossegos e inquietaçóes, com todo o espanto, horror ou encantamento pela excecionalidade da ação humana, que rasga ou ilumina fronteiras de finitude. Esses percursos da criação merecem, hoje, a atenção e análise dos Estudos Literários e, como não podia deixar de ser, dos Estudos Clássicos, muito peculiarmente. Importa, pois, proceder à publicação sistemática de estudos deste cariz, que se destaquem pela qualidade científica e pela originalidade, sendo dedicados, sobretudo, a autores de língua portuguesa. Assim se dá corpo à linha editorial MITO E (RE)ESCRITA.

Este livro, realizado no âmbito do Convénio de Cooperação Académica entre o CECH - Centro de Estudos Clássicos e Humanísticos da UC - e o PRAGMA - Programa de Estudos de Filosofia Antiga da UFRJ -, reúne um conjunto de estudos sobre a recepçáo de temas e modelos greco-latinos na literatura e cultura de Portugal e Brasil.

A sua originalidade resulta da participação de diferentes culturas e das especialidades académicas diversas dos investigadores que nele participam, provenientes da Literatura, da Filosofia e da História Antiga. O lapso de tempo abrangido, que vai do séc. XVI ao XX, permite uma visáo de conjunto da evoluçáo operada no perfil cultural de ambos os países e na definição de um trajeto em boa parte comum. 


\section{A RECEPÇÃO DOS CLÁSSICOS EM PORTUGAL E NO BRASIL}

Maria de Fátima Silva Maria das Graças de Moraes Augusto COORD. 


\section{Estruturas Editoriais}

Série Mito e (Re)escrita

Estudos Monográficos

ISSN: 2182-8814

\section{Diretor Principal}

Main Editor

Maria de Fátima Silva

Universidade de Coimbra

\section{Assistentes Editoriais}

Editoral Assistants

Elisabete Cação, Nelson Ferreira

Universidade de Coimbra

\section{Comissão Científica}

Editorial Board

Ana Maria Tobia

Universidad de la Plata

Andrés Pocińa

Universidad de Granada

Carmen Morenilla

Universidad de Valencia

Concepción López Rodríguez

Universidad de Granada

Fernando García Romero

Universidade Complutense de Madrid

Francesco de Martino

Università di Foggia
Francisco de Oliveira

Universidade de Coimbra

José Augusto Bernardes

Universidade de Coimbra

Maria das Graças Augusto

Universidade Federal do Rio de Janeiro

Milagros Quijada

Universidad Pais Basco

Nair Castro Soares

Universidade de Coimbra

Tereza Virgínia Barbosa

Universidade Federal de Minas Gerais 


\section{A RECEPÇÃO DOS CLÁSSICOS EM PORTUGAL E NO BRASIL}

Maria de Fátima Silva Maria das Graças de Moraes Augusto COORD. 
Título Title

A recepção dos Clássicos em Portugal e no Brasil

Reception of the Classics in Portugal and Brazil

Coord. Ed.

Maria de Fátima Sousa e Silva, Maria das Graças de Moraes Augusto

Editores Publishers

Imprensa da Universidade de Coimbra

Coimbra University Press

www.uc.pt/imprensa_uc

Contacto Contact

imprensa@uc.pt

Vendas online Online Sales

http://livrariadaimprensa.uc.pt

Coordenação Editorial Editorial Coordination

Imprensa da Universidade de Coimbra

Conceção Gráfica Graphics

Carlos Costa

Infografia Infographics

Nelson Ferreira

Impressão e Acabamento Printed by

Simōes \& Linhares, Lda.

ISSN

2182-8814

ISBN

978-989-26-1042-9

ISBN Digital

978-989-26-1043-6

DOI

http://dx.doi.org/10.14195/978-989-26-1043-6

Depósito Legal Legal Deposit

$396677 / 15$
Annablume Editora * Comunicaçăo

www.annablume.com.br

Contato Contact

@annablume.com.br

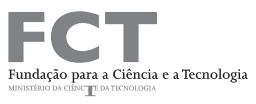

$\mathrm{POCI} / 2010$

Projeto UID/ELT/00196/2013 -

Centro de Estudos Clássicos e Humanísticos da Universidade de Coimbra

\author{
(C) Setembro 2015 \\ Annablume Editora * São Paulo \\ Imprensa da Universidade de Coimbra \\ Classica Digitalia Vniversitatis Conimbrigensis \\ http://classicadigitalia.uc.pt \\ Centro de Estudos Clássicos e Humanísticos \\ da Universidade de Coimbra
}

A ortografia dos textos é da inteira responsabilidade dos autores.

Trabalho publicado ao abrigo da Licença This work is licensed under

Creative Commons CC-BY (http://creativecommons.org/licenses/by/3.0/pt/legalcode) 


\section{A recepção dos Clássicos em Portugal e no Brasil Reception of the Classics in Portugal and Brazil}

Coord. ED.

Maria de Fátima Sousa e Silva, Maria das Graças de Moraes Augusto

Filiaçấo AfFiliation

Universidade de Coimbra, Universidade Federal do Rio de Janeiro

\section{Resumo}

Este livro, realizado no âmbito do Convénio de Cooperaçáo Académica entre o $\mathrm{CECH}$ - Centro de Estudos Clássicos e Humanísticos da UC - e o PRAGMA - Programa de Estudos de Filosofia Antiga da UFRJ -, reúne um conjunto de estudos sobre a recepçáo de temas e modelos greco-latinos na literatura e cultura de Portugal e Brasil.

A sua originalidade resulta da participação de diferentes culturas e das especialidades académicas diversas dos investigadores que nele participam, provenientes da Literatura, da Filosofia e da História Antiga. O lapso de tempo abrangido, que vai do séc. XVI ao XX, permite uma visão de conjunto da evolução operada no perfil cultural de ambos os países e na definiçáo de um trajeto em boa parte comum.

Palavras-chave

Filosofia grega, tragédia, épica, tradução, romance, cinema.

\footnotetext{
AbSTRact

This book, prepared as a step in the academic cooperation between the CECH - Centro de Estudos Clássicos e Humanísticos of the UC - and the PRAGMA - Program of Ancient Philosophical Studies of the UFRJ -, includes several studies on the reception of Greco-Latin themes and models in the literature and culture of Portugal and Brazil.

Its originality is a consequence of putting together two different cultures and several disciplines, as researchers come from Literature, Philosophy and Ancient History. The period considered, from the 16th to the 20th centuries, allows a global view of the cultural evolution of the two countries, in a good part made in common.
}

KEYwORDS

Greek philosophy, tragedy, epic, translation, novel, cinema. 


\section{Coordenadores}

Maria de Fátima Sousa e Silva é Professora Catedrática do Instituto de Estudos Clássicos da Universidade de Coimbra. Desenvolveu, como tese de doutoramento, um estudo sobre a Comédia Grega Antiga (Critica do teatro na Comédia Grega Antiga), e, desde então, tem prosseguido com investigação nessa área. Publicou já traduçôes comentadas de outras nove comédias de Aristófanes, além de um volume com a tradução das peças e dos fragmentos mais significativos de Menandro.

Maria das Graças de Moraes Augusto é Professora Titular no Departamento de Filosofia do Instituto de Filosofia e de Ciências Sociais da Universidade Federal do Rio de Janeiro (UFRJ). A sua investigação sobre História da Filosofia Antiga abrange temas como Platão e a herança platónica, filosofia e conhecimento no pensamento antigo, filosofia e literatura na tradição antiga e recepção dos clássicos gregos no Brasil.

\section{EDITORS}

Maria de Fátima Sousa e Silva is Professor Catedrática in the Institute of Classical Studies of the University of Coimbra. As her PHD thesis, she worked about Ancient Greek Comedy (Theatrical criticism in Ancient Greek Comedy). From then, she went on with the same research and published several articles. She also published translations, with commentary, of nine of the Aristophanic comedies, and a volume with the translation of the plays and the most well preserved fragments of Menander.

Maria das Graças de Moraes Augusto is Professor Titular in the Department of Philosophy of the Institute of Philosophy and Social Sciences of the Federal University of Rio de Janeiro (UFRJ). Her research about History of Ancient Philosophy comprehends topics as: Plato and his heritage, philosophy and knowledge in ancient thought; philosophy and literature in ancient tradition; reception of Greek classical culture in Brazil. 


\section{SUMÁRIO}

Apresentação

Maria das Graças de Moraes Augusto, Politeía tropical: a recepção dos clássicos,

a tradição política no Brasil do século XIX e a tradução das Categorias aristotélicas

por Silvestre Pinheiro Ferreira

(Tropical politeía: Classical reception, political tradition in Brazil during the 19th century

and the translation of Aristotle' Categories by Silvestre Pinheiro Frerreira)

Ana Virgínia Teixeira da Paz Pinheiro, Musas errantes:

tesouros da Antiguidade Clássica no labirinto da Biblioteca Nacional Brasileira

(Errant Muses: treasures from Classical Antiquity in the labyrinth of the Brazilian National Library)......

Diogo Ferrer, Eudoro de Sousa e a Mitologia

(Eudoro de Sousa and Mythology)....

Markus Figueira da Silva, Câmara Cascudo em defesa de Epicuro

(Câmara Cascudo defending Epicurus)

Luisa Severo Buarque de Holanda, Medéia carioca

(Medea carioca).

Maria do Céu Fialho, Ecos de Platão em Vergílio Ferreira

(Platonic echoes in Vergílio Ferreira).

Delfim Leão, Imaginário clássico na poesia de António Arnaut

(Classical imaginary in the poetry of António Arnaut)

Susana Marques Pereira, Motivos clássicos na poesia novilatina em Portugal:

Manuel da Costa

(Classical motives in neo-Latin poetry in Portugal: Manuel da Costa).....

Nuno Simóes Rodrigues, Uma Ifigénia portuguesa: "Noite escura" de João Canijo

(A Portuguese Iphigeneia: "Noite escura" by João Canijo)

Paula Barata Dias, Uma leitura de Mau Tempo no Canal de Vitorino Nemésio segundo as estruturas do trágico

(A Lecture of Vitorino Nemésio's Mau tempo no canal, in accordance with tragic structures) 
Alexandre Schmitt, $A$ phýsis grega e o Brasil: as viagens de Von Martius

(Greek physis in Brazil: the travels of Von Martius)

Maria de Fátima Silva, Fantasia para dois coronéis e uma piscina.

Ecos clássicos num contexto do séc. XX português

(Fantasia para dois coronéis e uma piscina. Classical echoes in a Portuguese 20th century context)

Jorge Deserto, O que não cabe nas palavras -

peripécia e reconhecimento em A tragédia da Rua das Flores e n' Os Maias

(What words do not contain -

peripeteia and anagnorisis in A tragédia da Rua das Flores and in Os Maias)

Maria Luísa Portocarrero, Presença dos Gregos no pensamento filosófico de Miguel Baptista Pereira

(Greek presence in Miguel Baptista Pereira's philosophical thought)

Índice de autores

Autores 
A recepção dos Clássicos em Portugal e no Brasil 
Página deixada propositadamente em branco 


\section{Apresentaçáo}

No âmbito do Convênio de Cooperação Acadêmica e Intercâmbio Técnico, Científico e Cultural assinado entre a Universidade de Coimbra e a Universidade Federal do Rio de Janeiro, em 2006, o CECH - Centro de Estudos Clássicos e Humanísticos da UC e o PRAGMA - Programa de Estudos em Filosofia Antiga da UFRJ, firmaram, em 2011, um Termo Aditivo a este Convênio de modo a dar maior implemento às pesquisas que já vinham sendo desenvolvidas conjuntamente - tanto no contexto geral das relaçóes entre Literatura e Filosofia na tradição do pensamento antigo, quanto no contexto específico, relativo aos diferentes gêneros de discurso surgidos na Antiguidade Clássica -, bem como alargar essas discussóes para o quadro particularizado da herança clássica nas culturas brasileira e portuguesa ao longo das suas histórias.

Nesse sentido, o Termo Aditivo prevê encontros regulares de pesquisa, sob o formato de pequenos colóquios, tendo sido o I Colóquio realizado na UFRJ, em Setembro de 2012, com o tema: Politeía e utopia no pensamento antigo, de que foram já publicados os resultados no vol. 16/17 da revista Kléos.

O II Colóquio realizou-se na UC, entre os dias 29 e 31 de Maio de 2013, subordinado ao tema da Recepção dos Clássicos em Portugal e no Brasil; com uma participaçáo significativa de investigadores de ambas as partes, este encontro centrou-se em volta de uma temática promissora, que constitui parte das prioridades definidas por esta parceria.

$\mathrm{O}$ volume que agora se publica, dedicado a estudos de recepção, retoma e amplia as reflexóes então apresentadas e discutidas, contando com a colaboração de um grupo variado de acadêmicos portugueses e brasileiros, essencialmente provenientes das áreas de Língua e Literatura, Filosofia e História Antigas. Talvez a sua maior originalidade esteja justamente nesta parceria, entre diferentes culturas e especialidades acadêmicas, que pode trazer um contributo decisivo a uma área ainda em desenvolvimento, a da recepção dos clássicos em ambos os países e a definição de duas culturas paralelas. O lapso de tempo abrangido, aquele que vai do séc. XVI ao XX, proporciona também uma visão do conjunto e das mudanças operadas no estabelecimento do perfil cultural de Portugal e Brasil, desde os tempos do Renascimento até à contemporaneidade, com tudo o que esse trajeto implica de partilha de uma experiência histórica em boa parte comum. 
O contexto privilegiado neste volume para a recepção dos motivos clássicos é o que aborda os discursos nos quais a herança clássica se faz presente sob diversas formas, a literatura - o conto, o romance, a poesia, o teatro -, a filosofia, a historiografia, a antropologia, as artes visuais e as ciências naturais. A tradição clássica que espelham é, por um lado, aquela que os influencia nos seus temas, como também a que lhes dita códigos estéticos, morais, políticos, filosóficos e culturais. Possibilita, assim, diferentes contributos que valorizam tanto o efeito de inovação e liberdade que assiste a cada reescrita, quanto a construção de novas convençóes formais.

De entre o mundo literário português, vários nomes, a partir da época do Renascimento, são contemplados pela importância que têm como intermediários na adopção do pensamento clássico. Do Renascimento português, Manuel da Costa representa, nos temas e modelos poéticos, a extensão à poesia portuguesa da época dos padróes que circulavam, com enorme pujança, por todo o mundo culto da Europa. Avançando para o séc. XIX, Os Maias de Eça de Queirós, um romance que disciplinou o estudo da Literatura Portuguesa para muitas geraçóes, revela aqui o seu potencial clássico, uma faceta que, nos múltiplos estudos que lhe têm sido dedicados, não tem merecido particular atenção; e, no entanto, alguns dos cânones trágicos, com uma afinidade particular com o tema de Édipo, estão implicados nos temas relevantes deste romance. Entre os contemporâneos, destacam-se os nomes de dois reconhecidos e premiados romancistas, Vergílio Ferreira e Mário de Carvalho, que, cada um num diálogo diferente com o mundo da Antiguidade clássica, tiveram a mestria de articular o pensamento, o estilo, as alusóes a essas fontes com a sensibilidade do mundo cultural português, seu e nosso contemporâneo, e com a sua própria experiência de vida. Na poesia, António Arnaut, jurista e político bem conhecido da actualidade portuguesa, regressa, ainda que discretamente, aos mitos gregos, com preferência pelos que se caracterizam por uma marca iniciática, como os de Dioniso, Elêusis e Orfeu.

Mas outras formas de expressão artística estão igualmente representadas nesta colectânea, caso daquela que se identifica como inovadora e particularmente atraente à sensibilidade dos nossos tempos: o cinema. Cumprindo uma transposição necessária, quando está em causa uma maior distância entre a natureza dos modelos e a sua repercussão sob esta outra forma, o entusiasmo da produção cinematográfica pelos mitos antigos combina-se naturalmente com as exigências de uma outra realidade social e uma diferente sensibilidade crítica.

O estudo minucioso da tradução das Categorias de Aristóteles por Silvestre Pinheiro Ferreira marca um aspecto da maior relevância no cruza- 
mento das duas culturas em análise, a portuguesa e a brasileira. A tradução e divulgaçáo do texto aristotélico no novo continente vem responder às necessidades de um momento fundacional na história do Brasil: aquele em que foi preciso ponderar as modificaçóes políticas, sociais e culturais que mobilizaram o país ao longo do século XIX, em particular a formação de uma "identidade nacional" manifesta sob diferentes contextos estruturais, entre os quais se impóe a questão constitucional. Ainda no âmbito da filosofia e da mitologia antigas e da sua presença na formação intelectual brasileira, reencontraremos a figura luso-brasileira de Eudoro de Sousa e os seus títulos remissivos para a mitologia e para o pensamento pré-socrático.

Do lado brasileiro, são ainda expressivos os estudos dedicados à presença do pensamento antigo no contexto intelectual e cultural: a versão de Câmara Cascudo, etnógrafo, antropólogo, folclorista, vulto destacado no estudo da cultura brasileira e das suas raízes clássicas, aqui retomado em um dos 34 diálogos que compóem a obra Prelúdio e Fuga do Real: o seu encontro com Epicuro, em Nova York, onde se discute a hipótese do "prazer sem sentidos"; bem como a versão do botânico bávaro, Carl Friedrich von Martius, da natureza e da Flora Brasiliensis, vista, lida e analisada à luz da tradição clássica, no Brasil do século XIX.

Particular é o caso de Gota d'Água, a célebre reescrita musicada de Medeia por Chico Buarque e Paulo Pontes. O sentido de intervenção deste texto sobre a realidade brasileira contemporânea tornou-o uma das criaçóes mais bem sucedidas da versão euripidiana do mito.

Também no caso brasileiro, outras marcas da realidade cultural, além da literatura, da filosofia e das ciências naturais, merecem reflexão. Assim, as práticas de catalogação dos textos impressos artesanalmente em grego e em outras línguas consideradas "exóticas", do acervo da Biblioteca Nacional brasileira, ajudam a descobrir um espólio cujo potencial está ainda, pelo menos em parte, inédito.

$\mathrm{Na}$ sua variedade, este volume oferece, sobre um território geograficamente bem definido - Portugal e Brasil -, uma amostragem da vitalidade dos paradigmas clássicos, um tema sempre em aberto mas cuja implantação é já de uma enorme importância como base de fusão cultural.

Maria de Fátima Silva Universidade de Coimbra Maria das Graças de Moraes Augusto Universidade Federal do Rio de Janeiro 
Página deixada propositadamente em branco 


\title{
Politeía Tropical: a recepção dos clássicos, a tradição política no Brasil do século XIX e a tradução das Categorias aristotélicas por Silvestre Pinheiro Ferreira
}

(Tropical Politeía: Classical reception, the political tradition in nineteenth-century Brazil and the translation of Aristotle's Categories by Silvestre Pinheiro Ferreira)

\author{
Maria das Graças de Moraes Augusto \\ Instituto de Filosofia e Ciências Sociais \\ Universidade Federal do Rio de Janeiro
}


Página deixada propositadamente em branco 
Resumo - A importância do século XIX para a história da recepção dos clássicos gregos na vida política brasileira e as traduçôes que são elaboradas ao longo desse período, além de serem um fato inequívoco, podem nos auxiliar a compreender o processo de concepção da ideia de uma "nação brasileira".

Nesse sentido, nosso objetivo aqui consiste na retomada da tradução das Categorias, de Aristóteles, feita por Silvestre Pinheiro Ferreira, e publicada no Rio de Janeiro, em 1814, pela Impressão Régia, para servir de base às suas Preleçôes Filosóficas, ministradas entre 1813-1815, no Rio de Janeiro, no contexto das obras do autor - a Gramática Filosófica e a Memória sobre um novo princípio da Teórica do Calórico-, publicadas, no jornal O Patriota, também, no Rio de Janeiro, em 1813, e nos 30 fascículos que compóem suas Preleçôes Filosóficas, buscando evidenciar que a 'lógica dos termos' aristotélica subjaz em toda a discussão silvestriana no referido período.

Palavras-Chave - Silvestre Pinheiro Ferreira. Aristóteles. Categorias. Preleçóes Filosóficas. O Patriota. Corte Portuguesa no Brasil.

Abstract - The importance of the nineteenth century to the history of the reception of Greek classics in Brazilian political life and the texts that were translated during this period, in addition to being an unequivocal fact, can help us to understand the process of the conception of the idea of a "Brazilian nation".

In this sense, our goal here is to revisit Silvestre Pinheiro Ferreira's translation of Aristotle's Categories, published in Rio de Janeiro in 1814 by the Royal Printing, to serve as a basis for his Philosophical Lectures, held between 1813 and 1815, in Rio de Janeiro, in the context of the works of the author - the Philosophical Grammar and the Memoir on a new principle of the caloric theory, published in 1813, also in Rio de Janeiro, in the newspaper The Patriot and in the 30 fascicles that form his Philosophical Lectures, seeking to highlight that the Aristotelian term logic underlies the whole Silvestrian discussion during the above mentioned period.

Keywords - Silvestre Pinheiro Ferreira. Aristotle. Categories. Philosophical Lectures. The Patriot. Portuguese Court in Brazil.

À memória de Germanus Strazzeri, com saudades das nossas tardes de trabalho na Biblioteca Nacional do Rio de Janeiro.

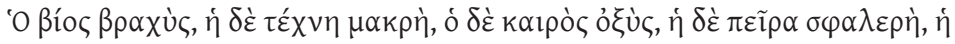

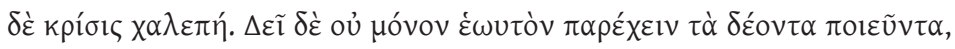

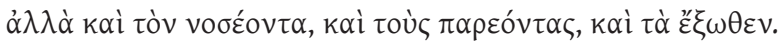

$$
\text { Hp., Aph., I, } 1 .
$$

"Os fatos são passageiros; as datas incertas; os homens mortais, - só as ideias são permanentes e eternas as categorias por que elas se exprimem."

Pedro Nava, Capitulos da História da Medicina no Brasil, 1948. 
Dentre as modificaçóes políticas, sociais e culturais que mobilizaram o Brasil ao longo do século XIX, uma delas é, evidentemente, a formação de uma "identidade nacional" manifesta sob diferentes contextos estruturais, entre os quais a questão constitucional será um tema fundamental.

E aqui, quando utilizamos a expressão 'questão constitucional', o sentido nela expresso tem um significado mais largo do que aquele que, em princípio, poderíamos reduzir ao processo de elaboração e fixação de uma Carta Constitucional.

Nesse sentido, o que estamos denominando "politeía tropical” é um duplo processo que envolve, antes de qualquer outra imposiçáo, o sentido atribuído na tradição do pensamento antigo ao termo politeía, isto é, a extensão semântica entre a constituição política, o princípio de cidadania e os direitos e os deveres do Estado e do cidadão, de tal modo que tenhamos uma possibilidade de leitura e compreensão da presença intensa dos autores clássicos no contexto da formação do Brasil como nação, ao longo do século XIX. ${ }^{1}$

Sob esse aspecto, a importância do século XIX para a história da recepção dos clássicos gregos na vida política brasileira e as traduçóes que são elaboradas ao longo desse período, além de serem um fato inequívoco, podem nos auxiliar na compreensão do processo de formação da ideia de 'pátria', de 'naçấo', de 'brasilidade', e, se nos ativermos à presença da tradução de autores clássicos, veremos que eles estáo presentes em momentos chave da vida política brasileira e que podem ser vistos, muito claramente, a partir de três acontecimentos históricos vitais na construção da concepção de 'nação brasileira': [i] a alteração do estatuto político, de Colônia a Reino Unido de Portugal e Algarves, em 1808, com a vinda da Corte portuguesa para o Brasil; [ii] a emancipação política com a independência de Portugal, em

1 E aqui parece-nos, ainda, oportuno lembrar que o termo não é usual na língua grega arcaica, sendo encontrado na prosa jônico-ática a partir da segunda metade do século $\mathrm{V}$ a.C, inicialmente nos textos dos historiadores e, em seguida, frequentemente, nos textos de filósofos e oradores. Ademais, o termo politeía é uma palavra de difícil tradução, cujo significado está interligado aos de pólis e polites: se a pólis se constitui em uma "comunidade de cidadãos", a politeía, enquanto modo de vida do cidadão, só ganha sentido no interior da pólis. Nesse sentido, a politeía se manifesta em dois aspectos vitais do pensamento político grego: o direito de cidadania e a forma de governo, o regime político, e enquanto direito de cidadania, a politeía determinava os direitos políticos do cidadão e sua participação na estrutura geral da pólis, não como um ato meramente jurídico entre o indivíduo e o Estado, mas como um corpo vivo, onde cada cidadáo participa da cidadania. Sobre o tema, veja-se, por exemplo: Ehrenberg 1980: 44-77; Manville 1990; Cataldi, 2004, e para uma análise do aparecimento e da difusão do termo politeía, veja-se Bordes 1982: 18-33. 
1822, e, [iii] a constituição de um "império constitucional" - e seus desdobramentos na guerra do Paraguai, na Abolição da Escravidão e na mudança Constitucional Republicana, em 1889.

Assim, a publicação, no Rio de Janeiro, em 1814, pela Impressão Régia, da tradução de Silvestre Pinheiro Ferreira das Categorias de Aristóteles - para servir de texto base para suas Preleçôes Filosóficas, ministradas a partir abril de 1813, no Real Colégio de São Joaquim -, a tradução do idílio de Meleagro de Gadara, A Primavera, por José Bonifácio de Andrada e Silva, publicada em Lisboa, em 1816, e as traduçóes da História da Guerra do Peloponeso de Tucídides, do Prometeu Acorrentado, de Ésquilo e da Odisséia, de Homero, feitas por D. Pedro II, marcarão, definitivamente, a presença e a importância dos clássicos gregos na formação política brasileira no século XIX², espelhando em seus contextos a expressão de momentos decisivos de nossa formação. Os elos entre esses três homens públicos e a tarefa de tradutor exercida por cada um deles, em diferentes momentos da vida política brasileira no século XIX, não são apenas intelectualmente convergentes mas espelham uma "visão de mundo" na qual o pensamento antigo constitui-se, tal como sugerido por Machado de Assis, em Esaú e Jacó, como um "par de lunetas" que nos permitem uma mais larga compreensão da emergência do Brasil como nação.

Não nos parece mero acaso o fato de Silvestre Pinheiro Ferreira e José Bonifácio de Andrada e Silva escreverem, em 1813, em O Patriota - jornal editado no Rio de Janeiro, e publicado pela Impressão Régia ao longo dos anos de 1813-1814 -, artigos sobre metalurgia e química; de Pinheiro Ferreira - o que já estava prenunciado em outro artigo publicado em $O$ Patriota, sobre a "gramática filosófica" que estaria na base de suas preleções -, traduzir e publicar as Categorias, em 1814, enquanto em 1816, José Bonifácio traduz e publica, em Lisboa, o idílio de Meleagro de Gadara; e que em 22 de novembro de 1843, em carta de Silvestre Pinheiro Ferreira a D. Pedro II, publicada pelo Diário do Rio de Janeiro ${ }^{3}$, reencontremos os problemas da 'constituição' e de uma monarquia constitucional, bem como a ideia de 'confederação' como modo de manutenção de um 'governo imperial', o que, sob um sentido alargado, poderá ser visto como uma reunião temática de nossos três tradutores, agora mediados na sequência política, pelo Imperador do Brasil, às voltas, ao longo do século XIX, com o

2 Para uma análise das relaçôes entre as Preleçôes Filosóficas, a tradução das Categorias, e a tradução do idílio de Meleagro de Gadara por José Bonifácio de Andrade e Silva, veja-se Moraes Augusto 2010: 313-350 e Moraes Augusto 2012/2013: 128-135.

3 Cf. Ferreira 1843: 1. 
Prometeu Acorrentado, de Ésquilo e com a História da Guerra do Peloponeso, de Tucídides, e, posteriormente à queda da monarquia, com a tradução da Odisséia, de Homero.

Nesse estudo - que é parte de uma análise mais larga, ainda em fase de redação e na qual estão incluídas e relacionadas as traduções acima indicadas -, nos deteremos na obra de Silvestre Pinheiro Ferreira, referente aos anos de 1813-1814, editadas no Rio de Janeiro, pela Impressão Régia: os artigos publicados no jornal $O$ Patriota, as Preleçôes Filosóficas, e a tradução das Categorias de Aristóteles, que, além de ser a primeira traduçáo de um autor antigo impressa no Brasil, completa 200 anos de publicação em 2014, procurando apontar em nossas análises, a funçáo que o pensamento antigo cumpriu na consolidaçấo da 'brasilidade' no século XIX. Daí o nosso esforço de uma leitura que, atenta ao tema da politeía, possa apontar para uma política fundada nas categorias da língua como base da 'nacionalidade'.

\section{As categorias da língua como base da 'nacionalidade': Silvestre Pinheiro Ferreira, as Preleçóes Filosóficas e a funcionalidade da tradução na crítica filosófica.}

Silvestre Pinheiro Ferreira chegou ao Rio de Janeiro, provavelmente, em 1809 ou $1810^{4}$, vindo de Londres como funcionário do Ministério dos Negócios Estrangeiros, ficando sem um cargo remunerado até 13 de maio de 1811, quando foi nomeado deputado da Junta do Comércio, e em 17 de fevereiro de 1815, diretor da Junta de Direção da Real Tipografia e da fábrica das cartas de jogar, da qual também era integrante José Maria Lisboa, o futuro Visconde de Cairus . Nesse período, Pinheiro Ferreira não só publicou trabalhos científicos e filosóficos no jornal O Patriota, ministrou, no Real Colégio de São Joaquim, suas Preleçôes Filosóficas e traduziu as

41810 é a data indicada por Inocêncio Francisco da Silva, em seu Dicionário Bibliográfico Português (Silva, 1862, p. 259-273, v.7), e aceita por muitos dos comentadores de sua obra para a chegada de Pinheiro Ferreira ao Brasil, entretanto, Maria Beatriz Nizza da Silva, após um rastreamento das cartas e ofícios enviados por ele a António de Araújo de Azevedo, futuro Conde da Barca, assinala que em 1809 Pinheiro Ferreira chegou a Londres, de onde, neste mesmo ano, embarcou para o Rio de Janeiro. Nesta cidade teria tido dificuldades para encontrar um posto remunerado, pois, "tendo chegado ao Brasil em 1809, ainda em maio de 1811 estava desempregado, vivendo de uma escassa pensão de 53\$000.” Cf. Silva 1975: 11-32. Sobre as relaçôes de Pinheiro Ferreira com o Conde da Barca, cf. Silva 1975: 9-45; Lima 2006: 335-356.

5 Cf. Silva 1975: 32. Para as possíveis funções exercidas junto à Real Tipografia, Cf. Silva 1975: 44-45. 
Categorias de Aristóteles, mas, também, redigiu, a pedido de D. João VI, o projeto de reforma da monarquia portuguesa, divulgado sob o título de Memórias politicas sobre os abusos gerais e modos de os reformar e prevenir a Revolução Popular, redigidas por ordem do Principe Regente - 1814/1815. ${ }^{6}$

Em 1819, foi escolhido para representar Portugal junto à comissão luso-britânica para a extinção do tráfico de escravos, mas, em meados de 1820, quando deveria seguir, como representante do governo português, para os Estados Unidos, a revolução liberal que explodira em Portugal e a crise política de fevereriro de 1821, no Rio de Janeiro, levou D. João VI a nomeá-lo Ministro do Exterior e da Guerra, ${ }^{7}$ condição na qual regressará a Portugal com o monarca, afastando-se do governo em 1823, e seguindo para Paris num exílio voluntário ${ }^{8}$ - onde poderá dedicar-se à filosofia e ao aprofundamento de suas teses políticas -, de onde só retornará a Portugal, em 1842, morrendo em Lisboa, em julho de 1846.

${ }^{6}$ As idéias aí apresentadas e sugeridas por Silvestre Pinheiro Ferrreira, já prevendo que se o Princípe Regente retornasse a Portugal o Brasil se emanciparia, eram demasiadamente arrojadas para tornarem-se públicas, e as observaçóes feitas para sua impressão são extremamente severas: "serão impressos [as memórias escritas por SPF] debaixo de todo o segredo, em presença de um criado de V.A.R., só com o administrador da Impressão Régia e os artífices necessários, queimadas ali mesmo as provas, desmanchadas as formas e tirados unicamente os exemplares precisos para as seguintes pessoas: conselheiros de Estado, o bispo capeláo-mor, os titulares maiores de 30 anos, os desembargadores do Paço, os conselheiros da Fazenda, os desembargadores da Casa da Suplicação, os deputados da Junta do Comércio e Mesa do Erário”. Apud: Silva 1975: 44. Cf. "Proposta sobre o regresso da corte para Portugal e providencias convenientes para prevenir a revolução, e tomar a iniciativa na reforma política”, 22 de abril de 1814. 3f. (FBN, Seção de Manuscritos, I-31,21,010.) e a edição das Memórias pela Revista do IHGB, v.47, 1884. A PUC-Rio, publicou uma versão ortograficamente atualizada, na Coleçáo Textos Didáticos do Pensamento Brasileiro, sob a Direção editorial de Celina Junqueira, em 1976. Essas Memórias foram, posteriormente, revistas e refinadas em seu exílio parisiense e lá publicadas. Cf. Ferreira, 1831 e 1834, Observaçōes sobre a Carta Constitucional do Reino de Portugal e sobre a constituição do Império do Brazil, publicada em 1831, com uma Advertência e em 2a edição, revista, em 1834.

7 A narrativa acerca de sua participação no governo, na fase brasileira, será descrita nas Cartas sobre a revolução do Brasil, publicadas nos Anais da Biblioteca Nacional, 1877, v. II e III. Veja-se, também, Memórias e cartas biográficas versando sobre os fatos politicos sobrevindos no Rio de Janeiro à revolução constitucionalista do Porto e Lisboa, desde suas repercussöes e consequentes sublevaçôes de fevereiro e abril de 1821 até o regresso de D. João VI com a corte para Portugal. Seção de Manuscritos da FBN, I-31, 21,009.

8 Em seu longo exílio parisiense Silvestre Pinheiro Ferreira dedicar-se-á à Filosofia e à reflexão política, tendo comentado as constituiçôes brasileira e portuguesa, e publicando, em 1834, o Manual do cidadão em um Governo Representativo, em 3 volumes, além de seu Essai sur la psychologie, em 1826, onde encontramos a edição em grego com a respectiva traduçáo dos textos gregos e latinos nele citados. 


\subsection{Os 'escritos patrióticos': as modulaçóes filosóficas entre a gramática e a ciência}

O Patriota, jornal literário, politico e mercantil, publicado ao longo dos anos de 1813-1814, no Rio de Janeiro, pela Impressão Régia, foi fundado por Manuel Ferreira de Araújo Guimarães, com uma proposta arrojada, contendo seções temáticas divididas em diferentes áreas do conhecimento - Artes, Agricultura, Hidrografia, Medicina, Literatura, História, Política, Comércio, e, ainda, uma Seção para as obras publicadas na Corte no mês de edição do jornal ${ }^{9}$ -, e contando, dentre os seus redatores, com nomes relevantes da vida política e intelectual de entâo: Borges de Barros, Silva Alvarenga, Garção Stockler, Mariano Pereira da Fonseca, Camilo Martins Lage, José Bonifácio de Andrada e Silva, José Saturnino, José Bernardes de Castro, Silvestre Pinheiro Ferreira ${ }^{10}$, o jornal trará "luzes para o Império", ${ }_{1}^{11}$ marcando, assim, não só as mudanças

9 Essas são as seções delimitadas no primeiro número do jornal, nos números seguintes elas seriam mantidas com pequenas alteraçôes que atendiam à classificação dos artigos contidos em cada número e onde encontraremos as seçôes de Matemática, Estatística, Mineralogia, Química, Eloquência, Agricultura, Geografia, Navegação, Hidrografia e Topografia, além de uma seção de Necrologia que aparecerá em alguns números.

10 Aqui, é oportuno lembrar que o jornal, embora tenha suas ligaçôes com o estado português bem delimitadas - é editado pela Impressão Régia, que concedia o "Com Licença”, indicando sua aprovação pelo Desembargo do Paço, tem entre seus colaboradores figuras vinculadas à estrutura de poder no Reino Unido de Portugal e Algarves -, não foi subscrito financeiramente pelo Estado, mas a um processo de colaboração mantido por seus subscritores financeiros. É sob essa ótica que muitos historiadores têm chamado a atenção para o fato de que entre seus colaboradores estão alguns importantes "herdeiros e continuadores do absolutismo ilustrado e fundadores do liberalismo político, no mundo luso-brasileiro"(Morel 2007: 29), como é o caso de José Bonifácio e Silvestre Pinheiro Ferreira, e que o projeto do jornal expressava o contexto de conflitos internos do Estado português, envolvendo questôes relativas ao fato de o Rio de Janeiro ser a sede da Monarquia e que, dentre os nomes contidos na primeira lista de assinantes, encontremos o Conde e a Condessa de Linhares, falecido no Rio de Janeiro, em janeiro de 1812, com suspeita de envenenamento, por assassinato ou suicídio, após conflitos com o Princípe Regente. Nesse sentido, o grupo de colaboradores do jornal estava ligado a D. Rodrigo de Sousa Coutinho, o Conde de Linhares, e a seu projeto iluminista e modernizador do império português: "Nesse contexto, o surgimento do periódico O Patriota explica-se justamente pela morte de d. Rodrigo de Sousa Coutinho[...]. Ou seja, aparece como uma espécie de obra póstuma de d. Rodrigo, ou tentativa de rearticulação de grupos e indivíduos que compunham e atuavam diretamente no Estado, identificados, de um modo geral, com a perspectiva reformista e com a ênfase no Brasil como local privilegiado no conjunto da naçáo portuguesa, ou com o poder pessoal do conde de Linhares" (Morel 2007: 36). Para uma análise do contexto político e intelectual e dos redatores e leitores de O Patriota, cf. Morel 2007: 15-39; Ferreira 2007: 41-66, e Lyra 1994.

11 A importância intelectual d'O Patriota, definida por Carlos Rizzini como "a melhor publicação literária não apenas da Colônia, mas do Reino, do Império sob Pedro I e 
Politeía Tropical: a recepção dos clássicos, a tradição política no Brasil do século XIX e a tradução das Categorias aristotélicas por Silvestre Pinheiro Ferreira

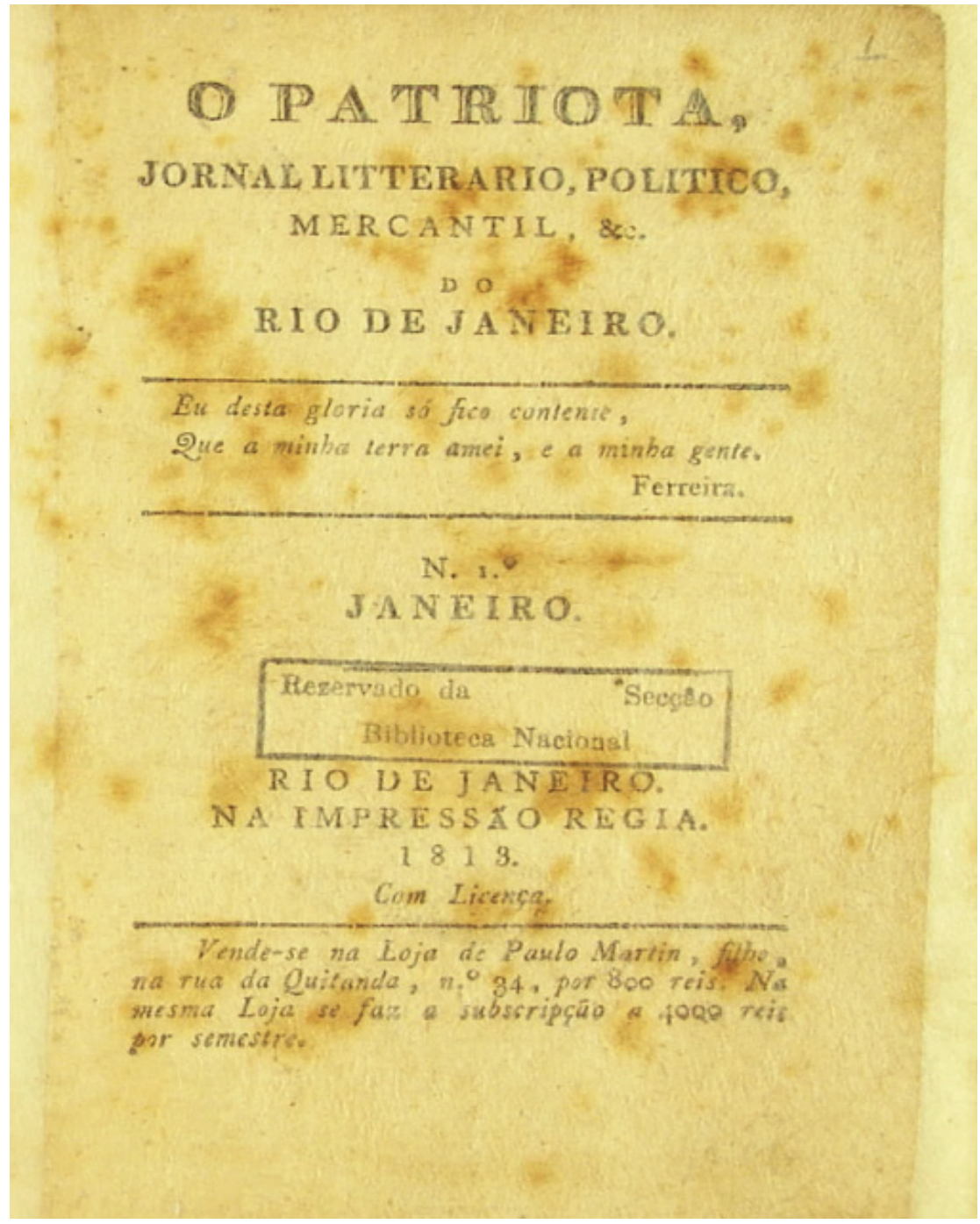

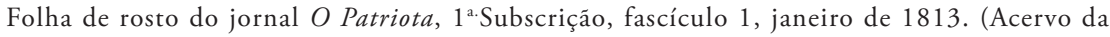
Fundaçāo Biblioteca Nacional, Rio de Janeiro) 
políticas instauradas pela nova condição política de Reino em detrimento da velha Colônia, mas, também, as novas estratégias alavancadas com a implantação da tipografia e com a circulaçáo de ideias através de livros agora impressos no Brasil. ${ }^{12}$

Nesse sentido, as palavras de abertura do editor no primeiro número do jornal já apontam para uma estratégia intelectual - que nos parece comum ao projeto de Pinheiro Ferreira em suas Preleçôes -, que consistia na extensão da "invenção das letras" à "contemporaneidade dos séculos", de modo que daí pudesse advir uma 'nação':

da Regência” (Rizzini 1957: 159), foi assinalada por muitos de seus comentadores, veja-se, sobretudo, Moraes e Camargo 1993; Salgado 2007; Kury 2007, e Alcides 2007. A expressão "luzes para o Império" é parte do título do capítulo As luzes para o Império: história e progresso nas páginas de O Patriota, de Manuel Luiz Salgado Guimarães, 2007: 67-101 evocando a presença das teses 'iluministas' em todo o projeto do jornal.

12 A Impressão Régia, e o que ela publicou entre 1808 e 1821, reflete bem as mudanças que foram alavancadas com a vinda da Corte para o Rio de Janeiro, pois, além dos atos oficiais do governo, foram editadas obras de caráter histórico, científico, literário e filosófico, valendo notar também a qualidade gráfica das publicaçôes: "A Impressão Régia foi uma excelente editora: publicou uma dezena de livros de real valor cultural, fez conhecer os poetas famosos, em moda em Portugal, imprimiu versos dos nossos, lançou o romance e a novela no Brasil, resolveu o problema do livro didático para o ensino superior inaugurado no Rio de Janeiro e cumpriu sua missão principal quanto à legislação. Não exagero afirmando que somente na segunda metade do século XIX, quando as editoras de Leuzinger e Laemmert estavam no auge, é que tivemos editoras comparáveis. [...] Examinando esses livros, esses folhetos de poucas páginas, ficamos admirados com a qualidade dos impressos. São composiçóes de uma sobriedade, de um bom gosto de fazer inveja aos nossos impressores atuais. Raramente, muito raramente na verdade, a tipografia brasileira atingiu um padrão tão alto de elegância e beleza. São composiçôes comparáveis e dignas dos grandes renovadores da tipografia, os Didot, os Bodoni. [...]. Não é preciso procurar muito para encontrar verdadeiras obras-primas tipográficas nessa vasta produção. Duas ou três obras entretanto destacam-se. São o Ensaio sobre a critica, os Ensaios moraes, ambos de Alexander Pope, traduzidas pelo conde de Aguiar, e os dois volumes da Memória da vida publica do lord Wellington, de José da Silva Lisboa. [...] A impressão é nítida e clara, a distribuição do texto e das notas nas páginas, a proporção das margens, tudo enfim, nessas obras [...] é perfeito.[...] Era um mestre o tipógrafo que compôs essas páginas de rosto. Soube dar destaque ao texto principal e deixar na sombra os dizeres complementares. Obteve beleza e harmonia sem truques e sem enfeites supérfluos. São páginas tão simples e perfeitas que nada se poderia mudar para melhorá-las." (Moraes 2006: 130-31). Veja-se, também, Lima 2006: 557-569. Acreditamos que a avaliação de Borba de Moraes vale, também, para a edição da tradução das Categorias e das Preleçôes Filosóficas, e d'O Patriota. 
"É uma verdade, conhecida ainda pelos menos instruídos, que sem a prodigiosa invençáo das letras, haveriam sido muito lentos os progressos nas Ciências, e nas Artes. [...] Os homens de todos os Séculos são contemporâneos, e o sábio no seu gabinete instrui-se ainda hoje com os Arquimedes e Apolonios, recrea-se com os Homeros e Anacreontes, consulta os Tucídides e os Lívios; admira a eloquência dos Demóstenes e Cíceros; e ligando eras interrompidas por longas séries de calamidades, salva através das irrupçôes dos Bárbaros, voa a despeito das injúrias do tempo, e prende remotíssimos anéis da cadeia não interrompida dos erros do entendimento, e dos crimes do coração humano. Mas instruídos pela física de que os raios do Sol, que dispersos aquecem apenas os corpos duros, juntos em um foco derretem os mais densos metais, os sábios se propuseram a comunicar-se reciprocamente suas luzes, para que da uniáo delas resultasse aquele intenso calor, que vencesse a frieza da preguiça, e a dureza da ignorância. As suas primeiras obras abriráo o caminho a outras mais perfeitas." ${ }^{13}$

E, em uma concepção em que a história se torna sempre "contemporânea" pela via das "letras", a 'ideia de nação' resultará, portanto, da compreensão do processo político através da 'maleabilidade' do conhecimento que, pelo "intenso calor" daí resultante, permitirá que a "frieza da preguiça" e a "dureza da ignorância" sejam vencidas. ${ }^{14} \mathrm{O}$ que o nome "patriota", de certo modo já explicitado na epígrafe ao título do jornal - "Eu desta glória só fico contente,/ Que a minha terra amei e a minha gente." ${ }^{15}$-, vem, de certo modo corroborar, com uma pluralidade de sentidos que tem sido largamente estudada pelos

13 Cf. O Patriota, S1,1, I, 3-4,1813; grifos nossos. Para referenciar O Patriota, seguimos o Índice de $O$ Patriota, elaborado por Diana Zaidman, com os dados na seguinte ordem: Subscrição, fascículo, mês, página e ano. Nas citaçôes dos textos do século XIX, as transcriçóes foram atualizadas apenas na ortografia, mantivemos tanto a pontuação original, quanto as maiúsculas, tal como utilizadas pelo autor no original, mesmo nas citaçốes não destacadas.

14 Vale notar aqui o sentido 'químico' da metáfora, o que parece, mais uma vez, aproximar o projeto silvestriano - pois os dois 'temas patrióticos' de nosso autor unem a gramática filosófica à teórica do calórico -, analisado a partir dos três textos do autor publicados no jornal $O$ Patriota, e que poderia também nos fazer suspeitar ser ele um dos autores da Introdução, no primeiro número do jornal.

15 Versos do poeta quinhentista português António Ferreira, em Aos bons engenhos. 
especialistas, ${ }^{16}$ é o alargamento da perspectiva corográfica como elemento dimensionador de sua dimensão intelectual, política e moral. ${ }^{17}$

A essa 'política epistolar' vale acrescentar ainda que o redator responsável divulga os livros publicados mensalmente na Corte, bem como noticia eventos relacionados às ciências, estabelecendo, também, uma dialógica com a cultura. Já no primeiro número encontramos a implementação das 'Cartas dos leitores", que aparece como uma chave interlocutória entre o responsável pelo jornal e seus colaboradores. E será exatamente nesse enclave que aparecerá, no primeiro número d'O Patriota, a primeira colaboração de Silvestre Pinheiro Ferreira: na Seção denominada 'Literatura', entre odes, um epigrama, uma "Lira inédita", de Tomás Antônio Gonzaga, e as "Máximas, Pensamentos e Reflexôes Morais", escritas por "Um brasileiro", encontraremos, ao final da seção, a carta dirigida por Pinheiro Ferreira ao redator d'O Patriota, abordando "uma questão gramatical sobre as sílabas". ${ }^{18}$

Referindo-se a uma questão gramatical, posta em uma "Sociedade Literária" na qual ele se encontrava, tendo sido indagado acerca do que era "sílaba", Pinheiro Ferreira proporá, em sua carta ao redator do jornal, dar publicamente, isto é, dar por escrito no jornal, a seguinte resposta:

"Chama-se sílaba o concurso de qualquer vogal ou ditongo com a sua figurativa e consoantes que se seguem até a figurativa de outra vogal ou ditongo em uma mesma palavra simples." ${ }^{19}$

A seguir, irá definir os ditongos como sendo o "concurso de uma vogal de meio tom com outra de tom inteiro", explicitando-os em um gráfico contendo duas colunas, uma com "exemplos" e outra com "contrastes", e a "sílaba figurativa" como sendo "a consoante muda que precede uma vogal", sozinha ou com uma consoante liquída, classificando, entáo, as mudas como sendo "simples" ou "compostas" (S 1, 1, I, 94, 1813).

\footnotetext{
16 A questão dos usos dos termos 'patriota' e 'pátria' no âmbito d'O Patriota possui já uma larga bibliografia, dentre a qual os textos de Morel 2007:15-39; Kury, 2007: 10-12, 141-157; Guimaráes 2007: 78-80, apontam para elementos importantes da questáo.

17 Sobre a dimensão intelectual e política do termo 'patriota' e a herança iluminista no jornal homônimo, cf. a análise de Guimarães 2007: 67-101.

18 No corpo do texto do jornal, a separação entre um artigo e outro, em uma mesma seção, é feita apenas por uma linha e abaixo dela a chamada epistolar: "Senhor redator", a indicação de que se trata de uma "questão gramatical sobre as sílabas, por S. P. F." nos é dada no 'Índice' do jornal. Cf. O Patriota, S1, 1, I, 93-95,128,1813 e no Índice Geral, publicado no último volume de 1814, Cf. S3, 6, XI-XII, 5,1814.
}

19 Ferreira, O Patriota, S1, 1, I, 93-94,1813. 
Ao final da carta, Pinheiro Ferreira dirá que essas definiçóes podem ser úteis, seja por sua "exatidão", seja pelo fato de despertarem em "alguém [ou a algum leitor?] a lembrança de outras melhores", daí ter tomado a "liberdade" de enviá-las ao redator para que, se "julgar que não são indignas dessa honra", publicá-las no referido "periódico", despedindo-se com a manifestação de "estimação" e "atenta veneração" (S 1, 1, I, 95,1813).

Aqui, pensamos que, no artíficio das "sílabas", sua definição, a função exercida pelos ditongos - um encontro de "tonalidades" -, e a associação entre vogais e consoantes, o que está em causa é o processo no qual as sílabas devêm 'palavras' e 'discursos', articulando e legitimando a tese subscrita na Introdução do primeiro número d'O Patriota, entre a "invenção das letras" e a constituiçáo da 'pátria' como substrato intelectual, corográfico e político de um Estado (ou de uma nação) emergente. ${ }^{20}$

Essa hipótese, se acompanharmos as publicações de Pinheiro Ferreira em O Patriota, não só, parece-nos, será confirmada, mas ganhará um estatuto próprio ao ser incluída em uma seção à qual atribuir-se-á a denominação de "Gramática Filosófica" (S1,4, IV, 21-29,1813), vindo na sequência das seçóes do jornal, logo após Literatura. ${ }^{21} \mathrm{O}$ estudo mais longo e detalhado, em relação àquele publicado em janeiro de 1813, com classificaçóes expostas graficamente, estabelecerá as 'categorias' gramaticais que compóem a língua e consequentemente subjazem aos discursos, será chamado por S.P.F. de "filosofia das línguas" (S1, 4, IV, 21, 1813).

20 O que, afinal, significaria "sociedade literária"? O contexto do jornal e o grupo de intelectuais a ele vinculados?, o ambiente no qual as Preleçôes estavam sendo gestadas, já que pelas indicaçôes que temos elas teriam tido o seu início em 26 de abril de 1813, ou ainda, as sociedades científicas e literárias existentes no Rio de Janeiro, tal como a Sociedade Literária do Rio de Janeiro, fundada por Manoel Ignácio da Silva Alvarenga, no final do século XVIII, localizada no andar térreo da casa do poeta, tendo por objetivo a troca de conhecimentos entre seus associados, e na qual buscou integrar a literatura à política? E é oportuno sublinhar que Silva Alvarenga também participou como autor em O Patriota, tendo falecido em 1814. Sobre esta questâo, cf. Candido 1976: 78, Moraes Augusto 2012/2013: 126-128.

21 Como a seção 'Gramática Filosófica' vem na sequência da seção 'Literatura', e como naquela altura a 'gramática filosófica' era considerada como parte da 'literatura', as relaçóes entre ambas parecem-nos conter certa ambiguidade; e como a seção 'Gramática Filosófica' só aparecerá em dois números d'O Patriota - nas S1, 4, IV, 1813 e S1, 5, V, 1813 -, e a de Literatura em quase todos os números - exceto no número S3, 4,VII-VIII,1814 -, é consequente pensarmos que ela estava diretamente articulada ao projeto silvestriano das Preleçöes, uma vez que ganha a explicitação de que seu autor dedica-se à "filosofia das línguas", delimitando, de certo modo, uma primeira distinção entre 'filologia' e 'filosofia'. 


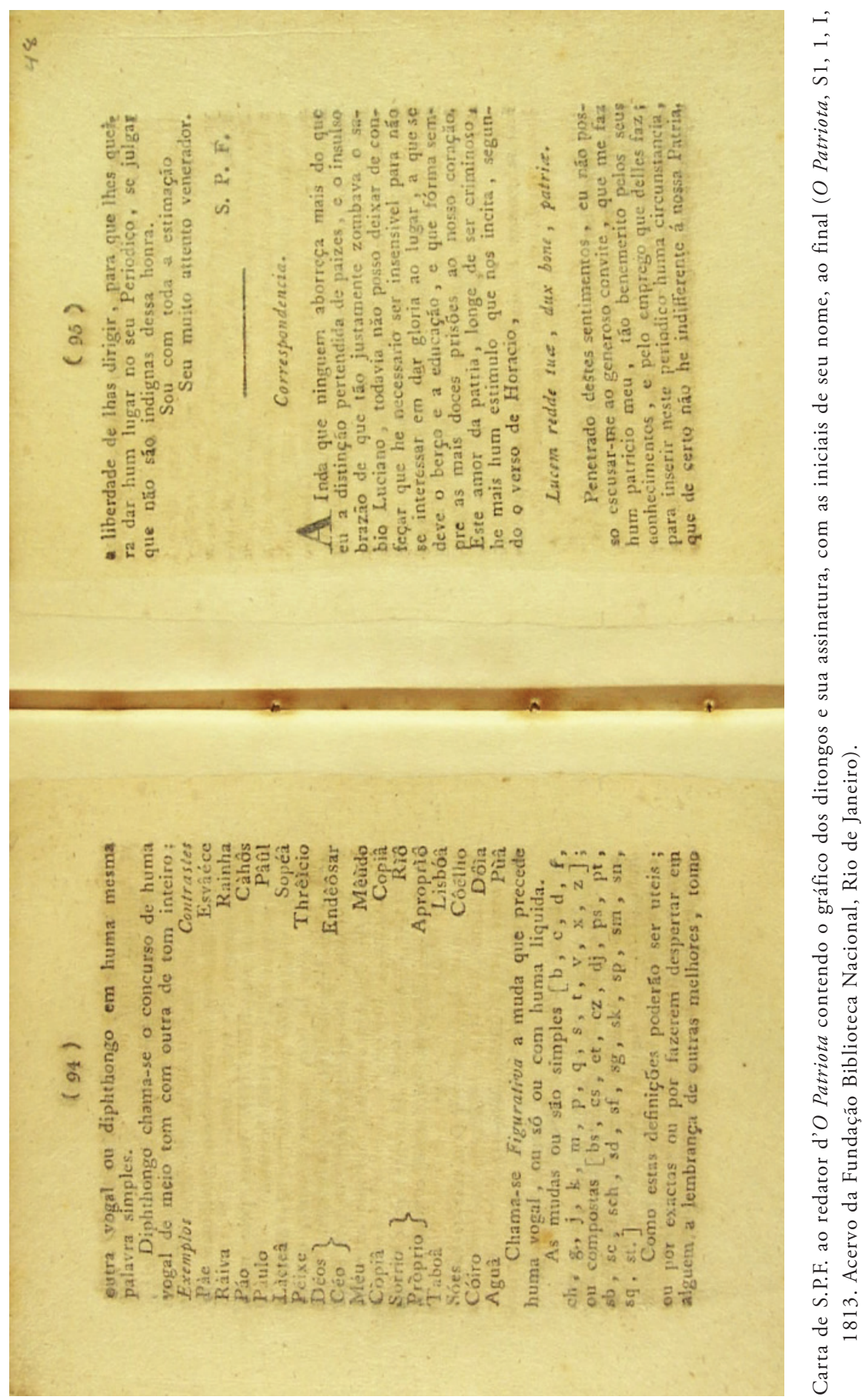


Apresentando uma classificação pormenorizada das sílabas e das palavras, numeradas no gráfico e em seguida pela remissão desses números, e explicitadas no texto, definirá agora as sílabas como sendo compostas de vogais e consoantes, dividindo-se, as primeiras, em simples e ditongos, e, as segundas, em figurativas e adicionais - guturais: h, ch, gh, g, k; palatinas: ill, j, ll, gn; maxilares: $\mathrm{j}, \mathrm{x}, \mathrm{tx}, \mathrm{dj}, \mathrm{sh}, \mathrm{s}, \mathrm{n}, \mathrm{l}, \mathrm{r}, \mathrm{rr}$; dentais: $\mathrm{dz}, \mathrm{tz}, \mathrm{ss}$, th, ç, d ,t; labiais: b, p m, w, ph; labio-dentais: $\mathrm{f}, \mathrm{v}-$, que podem ser simples ou compostas, sendo figurativas as consoantes, simples ou compostas ( $\mathrm{S} 1$, 4 , IV, 23, 1813), que precedem, em uma palavra simples, a uma vogal; as consoantes "que se seguem até a figurativa da vogal seguinte chamam-se adicionais" (Cf. S1, 4, IV, 25, 1813).

Por outro lado, as palavras serão divididas em 6 classes: verbo, nome substantivo e adjetivo -, advérbio, conjunção, preposição e interjeição, que serão assim definidas:

[i] Verbo são aquelas "palavras, que afirmam ou negam a existência real, ou hipotética do significado, em tempo determinado ou indeterminado"; e podem ser, em função do fato expresso pelo verbo, ativo ou "transeunte". Chama-se "ativo" o verbo que exprime um fato "como razão de outro fato", (ex."Firo") ; e "traseunte" se o efeito da açẫo verbal da qual "esse fato é razão, se verifica em outro sujeito" (ex."Cortei”), mas, se a ação se exprime no mesmo sujeito, "chama-se intranseunte" (ex."Cubro-me"), e, "se o fato, que o verbo exprime, se considera como efeito, chama-se o verbo passivo" (ex. "Foi ferido"); e, se a ação verbal não é considerada "nem como razão, nem como efeito; mas como um simples estado do sujeito", diz-se que o verbo é "neutro".

[ii] Nomes são aquelas palavras que "se denotam qualidades comuns a muitos indivíduos, chamam-se Apelativos (ex. "Animal, Ferro")" e podem expressar de modo absoluto ou relativo, quantidade, qualidade, lugar, tempo, causa, razáo, motivo, ocasiáo, modo, instrumento, matéria e efeito. Os demais nomes "são chamados de próprios"(ex. "Pedro, Roma"). Os nomes podem ser:

[ii.i] substantivos, que são aquelas palavras usadas para "designar o agente da significação de algum verbo", dos quais Pinheiro Ferreira dará como exemplos: homem, corpo, alma, entendimento, virtude, vício e força. (Cf. S1, 4, IV, 26, 1813);

e,

[ii.ii] adjetivos, que são aquelas palavras "que só servem a especializar os Substantivos", e são exemplificados com: grande, honrado, feliz. (Cf. S1, 4, IV, 26, 1813);

[iii] Advérbios são "as palavras, que se empregam para especializar a significação de algum verbo, ou de algum adjetivo"; 
[iv] Conjunções são aqueles termos "unicamente destinados a estabelecerem a relação de diferentes frases, e também às vezes as de diferentes partes de uma mesma frase entre si", e podem ser: copulativa, aditiva, ilativa, causal, concessiva, condicional restritiva, distintiva, e adversativa;

[v] Preposiçóes são aqueles termos usados "para estabelecer a relação de algumas palavras de uma mesma frase entre si”;

$\mathrm{e}$, finalmente, as

[vi] Interjeições, definidas como "aquelas, que, não significando nada, ou que além da sua significação, exprimem só pelo tom com que se pronunciam, o sentimento da pessoa, que delas se serve", e podem ser interrogativas, se supóem uma resposta; se não, são chamadas de exclamativas, variando em ambas as possibilidades a expressão de sentimentos de alegria, dor, indignação, compaixão, tenura, exortação, invocaçãa, chamamento e pergunta. (Cf. S1, 4, IV, 23-26, 1813)

A "gramática filosófica" de Silvestre Pinheiro Ferreira conterá não só exemplos das palavras e termos definidos pelo autor, mas, também, um gráfico do "sistema dos principais tons das Línguas Grega, Latina, Italiana, Portuguesa, Espanhola, Francesa, Inglesa, Holandesa, Alemã, dispostos conforme as suas afinidades" (Cf. S1,4, IV, 24, 1813), indicando que seu projeto gramatical está incluído em um contexto no qual a noção de "afinidade" é algo que importa em seu veio reflexivo entre a "arte de falar" e a "arte de pensar", e que será esclarecida como sendo "atração química"22, em sua Memória sobre um novo princípio da Teórica do Calórico, publicada em O Patriota, S2, 1, I, 3-11, 1813.

A introdução de uma "gramática filosófica" em O Patriota coloca mais uma vez o contexto discursivo do jornal em uma dimensão iluminista - e aqui não seria inoportuno relembrar que as "gramáticas filosóficas da língua portuguesa" surgem em Portugal na segunda metade do século XVIII, sob a influência da "l'Art de Parler", da Grammaire Genérale et Raisonnée de Port-Royal e da Logique et l'Art de Penser, de Antoine Arnault e Pierre Nicole. A primeira gramática a portar o título de 'filosófica' foi a de Bernardo de Lima e Mello Bacelar, Grammatica Philosophica e orthographica racional da Lingua Portugueza, publicada em Lisboa, na Officina de Simão Thaddêo Ferreira, em 1783, onde a 'gramática filosófica' é definida como sendo uma

22 É assim definida no Índice das vinte e duas primeiras preleções, Cf. Preleçôes Filosóficas, $\$ 165$. 
Politeía Tropical: a recepção dos clássicos, a tradição política no Brasil do século XIX e a tradução das Categorias aristotélicas por Silvestre Pinheiro Ferreira

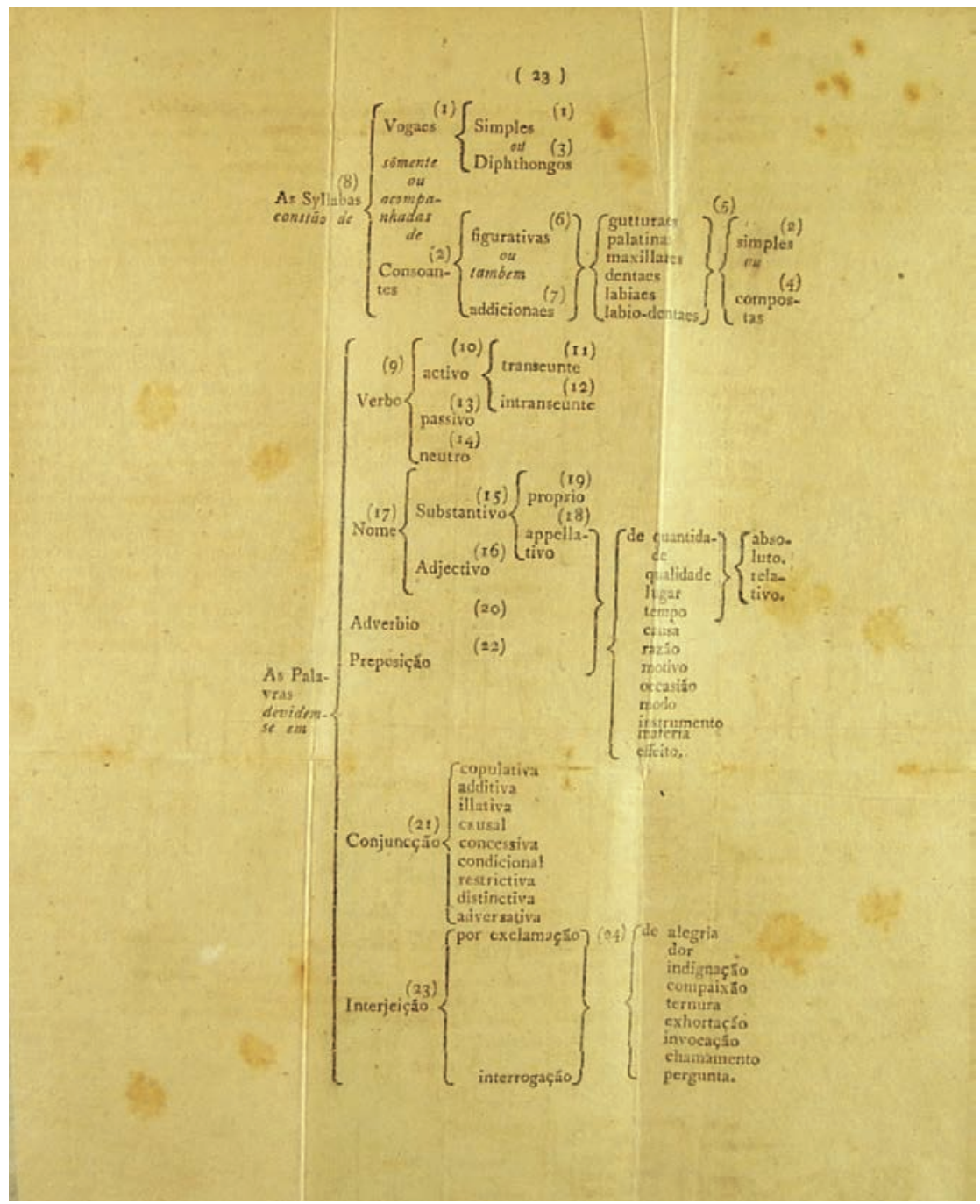

Quadro classificatório das sílabas e das palavras proposto por SPF em sua Gramática Filosófica. O Patriota, S1, 4, IV, 23, 1813. (Acervo da Fundação Biblioteca Nacional, Rio de Janeiro) 


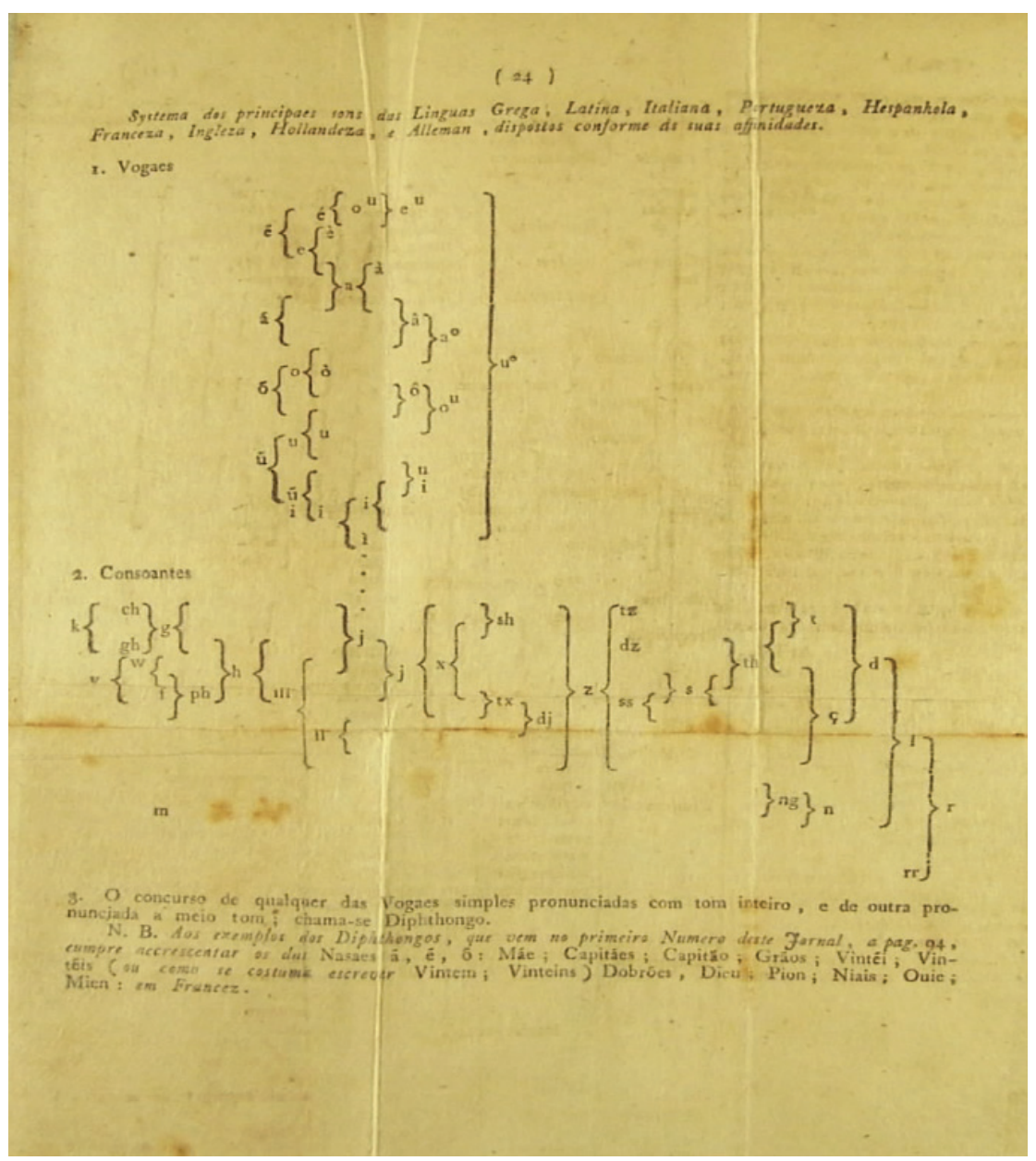

Sistema dos principais sons das línguas grega, latina, italiana, portuguesa, espanhola, francesa, inglesa, holandesa e alemã dispostas conforme as afinidades. (O Patriota, S1, 4, IV, 24, 1813. Acervo da Fundação Biblioteca Nacional, Rio de Janeiro) 
“[...] coleção de Leis, com que arrazoadamente fabricamos e dispomos os sons, que comunicam aos outros os nossos conceitos [...]. Começaram os homens a traficar; e comunicar-se mais, e mais; e para este fim inventaram cópia de sons. Destes, e dos inatos derivaram outros: e determinando as leis de os colocar vieram desta sorte a ter uma perfeita língua de comunicação, cujo arrazoado, ou discurso regulamentado, se chama Gramática Filosófica. Daqui se segue 1. que os sons regulados são, o objeto, e partes da Gramática Filosófica: 2. que o seu fim é a comunicação, que por estes sons se alcança: 3 . que a sua necessidade é igual a da sociedade recíproca: 4. que sua antiguidade é coeva a nossos primeiros pais". ${ }^{23}$

Ou, como assinala Jerônimo Soares Barbosa, na Introdução de sua Gramática Filosófica da Língua Portuguesa, escrita em Coimbra, em 1803, e só publicada em 1822:

“Toda gramática é um sistema metódico de regras, que resultam das observaçôes feitas sobre os usos e fatos das línguas. Se estas regras e observaçóes tem por objeto tão somente os usos e fatos de uma língua particular, a gramática será também particular. Se elas porém abrangem os usos e fatos de todos ou da maior parte dos idiomas conhecidos, a sua gramática será geral. Uma e outra pode ser, ou somente prática e rudimentar ou filosófica e razoada. [...]

Porém se o espírito se adianta a indagar e descobrir, nas leis físicas do som e do movimento dos corpos orgânicos, o mecanismo da formação da linguagem, e nas leis psicológicas as primeiras causas e razóes dos procedimentos uniformes que todas as línguas seguem na análise e enunciação do pensamento, então o sistema que d'aqui resulta, não é já uma Gramática puramente prática, mas científica e filosófica. [...] Que por isso a gramática foi sempre reputada da lógica, pela íntima conexão que as operaçôes do nosso espírito tem com os sinais que as exprimem. E esta é a razão por que os antigos filósofos, e os estoicos principalmente se faziam cargo d'ela nos seus tratados de filosofia, como Protágoras, Platão, Aristóteles, Teodetes, Diógenes, Crisipo,

23 Cf. Bacelar 1783: 2-3. Com o mesmo título de 'gramática filosófica' temos ainda a de Couto e Melo, publicada em Lisboa, pela Impressão Régia, em 1818; e a de Jerônimo Soares Barbosa, Grammatica Philosophica da Lingua Portugueza, ou Principios de Grammatica Geral applicados á nossa linguagem, publicada em Lisboa, em 1822, pela Typographia da Real Academia das Sciencias. 
Palemon e outros, sobre os quais se pode ver Laercio nas suas vidas e Quintiliano Inst. Orat., I,6."24

Mas, nesse contexto gramatical, não podemos também esquecer a formação oratorina de Silvestre Pinheiro Ferreira e a importância de $O$ verdadeiro método de estudar, de Luís António Verney, no contexto do iluminismo português, no qual a gramática, tema da $1^{\text {a }}$ Carta dentre as 16 Cartas que compóem o método, é apresentada como "a porta dos outros estudos". ${ }^{25} \mathrm{~A}$ influência do iluminismo português, sua expressão nas 'gramáticas filosóficas' e na extensão relacional entre a "arte de falar" e a "arte de pensar", estará, marcadamente, presente nas Preleçóes Filosóficas, onde reencontraremos a classificação e a definição das palavras, apresentadas em O Patriota, e que compóem, na sequência, os seus comentários às Categorias de Aristóteles ${ }^{26}$.

Sob esse aspecto, é interessante observar, ainda, que as Preleçóes Filosóficas serão anunciadas e divulgadas, pela redação d'O Patriota, no mesmo número no qual Pinheiro Ferreira publica sua carta ao jornal explicitando as observaçóes acerca das sílabas, que havia sido apresentada de modo in-

24 Barbosa 1822: XI-XII. Para análise das gramáticas filosóficas em Portugal, veja-se Couto 2004: 11-31 e Gonçalves 2006.

25 Cf. Verney 1747: 4. Silvestre Pinheiro Ferreira ingressou na Congregação do Oratório em 1783, aos 14 anos de idade, com intenção de seguir a vida eclesiástica, e onde concluiu o curso de Humanidades. Mas, como indicam seus biógrafos, apesar de ter sido aluno de grande brilho, acabou por polemizar com Padre Teodoro de Almeida o que deu início a uma perseguição que terminou com a sua saída da Congregação e a renúncia à vida clerical, voltando-se, entáo, para o ensino leigo, tendo ministrado durante algum tempo aulas particulares de filosofia em Lisboa, até ser aprovado, por concurso, em 1794, para lente substituto na cadeira de Filosofia Racional e Moral no Colégio das Artes da Universidade de Coimbra. Em Coimbra, entretanto, Pinheiro Ferreira ficará pouco tempo, pois, em função de suas críticas a Verney e Genovesi, será mais uma vez perseguido e acusado de “jacobinismo”, fugindo para a França, em julho de 1797, a bordo de um navio holandês que deveria passar por aquele país. Todavia, seu roteiro será alterado, tendo desembarcado em Dover, e permanecido em Londres até conseguir recursos para chegar à Holanda, onde se encontrou com o futuro Conde da Barca - que terá importância capital na estada da Corte Portuguesa no Rio de Janeiro -, então Ministro de Portugal em Haia, que o acolheu. E, sob a proteção deste, foi nomeado interinamente secretário da Embaixada Portuguesa em Paris, e, em 1798, secretário da Legação Portuguesa na Holanda, tendo ainda acompanhado o Conde da Barca "em uma viagem de instrução ao Norte da Alemanha, regressando ambos a Lisboa em 1802” (Cf. Silva, 1862: 261-269 e Lima, 2006: 344).

26 Cf. Preleçôes Filosóficas, \$235-251. Se formos também conferir no "Índice não só destinado a indicar os lugares destas vinte e duas primeiras Preleçóes em que se trata das diferentes matérias, mas a dar uma idéia resumida delas e mesmo a corrigir e suprir alguns descuidos, em que se advertiu ulteriormente", encontraremos todos os termos da gramática filosófica d'O Patriota, igualmente definidos e com a indicação dos parágrafos em que são tratados. 
completo no primeiro número do jornal, isto é, sem o título de "gramática filosófica" e sem o reconhecimento de que seu autor é versado em questóes relativas à "filosofia das línguas" - agora explicitadas em termos de uma "gramática filosófica" -, portanto, a carta publicada no número 4, de abril de 1813, alarga os significados anteriores e reafirma a proximidade entre o projeto do jornal e o projeto das Preleçóes Filosóficas, e, a divulgação aí feita, parece, vem ratificar integralmente nossa hipótese: a política, tal como as sílabas, ganha 'substancialidade' nas articulaçôes de afinidade e repleção que, por sua vez, possibilitam não só os 'discursos', mas, também, a própria 'ação política', o que seria, posteriormente, ratificado pelo grande projeto exposto na 30a Preleçấo.

Assim, dizendo-se sem notícias modernas da Europa, o Redator do jornal afirmará ter a oportunidade de ocupar-se de uma notícia deveras interessante, pois, em lugar de "aterrar a humanidade, como as sanguinárias guerras, fazem o seu mais belo ornato, e concorrem diretamente a sua felicidade". Trata-se, pois, da notícia de abertura, em 1 de abril de 1813, da Academia Real Militar, com Aulas de Astronomia, Geodesia, Tática, Física e Química, proporcionando, assim, o "aumento das luzes", trazidas por "instituiçóes úteis", oferecidas à educação militar, e, depois de descrever todo o currículo que lá será estudado, o Redator do jornal informará aos seus leitores sobre as Preleçóes Filosóficas de Silvestre Pinheiro Ferreira, acrescentando:

"A este Régio estabelecimento [a Academia Real Militar] tenho a satisfaçáo de ajuntar o utilissimo Plano de Preleçôes Filosóficas de um homem de conhecido saber, e da mais bem merecida reputação. É escusado pronunciar sobre a sua utilidade, quando sobra a sua mesma exposição. Além da manifesta necessidade das matérias, que se vão explicar, brilha no Plano que se segue aquele espírito de método que é só produzido por uma madura meditação sobre as matérias, que tem já feito o objeto de um sério e acurado estudo.

O Curso de Preleções Filosóficas terá por objeto:

$1^{\circ}$ A Teórica do Discurso e da Linguagem: em que se exporão os Princípios da Lógica, da Gramática geral, e da Retórica.

$2^{\circ} \mathrm{O}$ Tratado das Paixóes: primeiramente consideradas como simples sensaçôes, e versando sobre matérias de Gosto; donde se deduzirão as regras da Estética, ou da Teórica da Eloquência, da Poesia, e das Belas Artes: depois consideradas, como atos morais, compreendidos nas ideias de Virtude ou de Vício, darão lugar a desenvolverem-se as maximas da Diceósina, que abrangerá a Ética e o Direito Natural. 
$3^{\circ} \mathrm{O}$ Sistema do Mundo: em que depois de se tratar das propriedades gerais dos Entes, ou da Ontologia, e da Nomenclatura das Ciências físicas e matemáticas, se expenderão as noçóes elementares da Cosmologia: e destas se deduzirão as relações Entes criados com o Criador, ou os Principios da Teologia Natural.

Além da Exposição de Teórica, haverá em cada uma das Preleçóes lição e análise de alguma Obra escolhida dos principais Filósofos, Oradores e Poetas, assim antigos como modernos, sagrados e profanos.

No dia 26 do corrente recitou o Sábio Professor um eloquente discurso sobre as matérias acima enunciadas, onde brilharam os princípios filosóficos que o distinguem, e prorrogou as suas Preleçôes para o dia 18 de Maio." (S1, 4, IV, 92-93, 1813, grifos nossos).

Visto sob essa ótica, não parece difícil inferir que temos claramente articuladas as 'categorias' da língua que irão gerir o que será definido nas Preleçôes Filosóficas, como a "arte de falar" e sua conjugação imediata com a "arte de pensar" 27, aí incluídas a tradução e a análise das obras de diferentes autores, como 'procedimento filosófico' que também compóe o aprendizado e o exercício da "arte de falar" com a "arte de pensar". Ora, se nos voltarmos, rapidamente, para o outro texto de Silvestre Pinheiro Ferreira, publicado no volume 1 da Segunda Subscrição d'O Patriota, em julho de 1813, "Memória sobre um novo princípio da Teórica do Calórico", veremos que "a arte de pensar" será exemplificada com um 'caso científico', e que, tal como as 'categorias' que sustentam a língua que compóe a "arte de falar", elucidam, também, as teses apresentadas na "Introdução" do primeiro número do jornal.

Nesse sentido, ao escolher o fenômeno da "explosão da pólvora", Silvestre Pinheiro Ferreira afirma que quando um fenômeno, apesar de todos os esforços, não pode ser reduzido a nenhum dos princípios constitutivos da Teórica da Ciência a qual ele pertence, pois isto implicaria na inferência de que a Teoria, mesmo não sendo falsa, "é defeituosa em seus princípios", e ainda que, se este fenômeno não puder ser reduzido a nenhum dos princípios de sua teórica, ou mesmo mostrar-se contrário a alguns desses princípios, pois isto significaria que este "princípio ou é hipotético ou tem sido demasiadamente generalizado", fica demonstrado que o fenômeno da explosão da pólvora é, exatamente, o princípio mais importante na "teórica do calórico":

\footnotetext{
27 Cf. Preleçōes Filosóficas, $\$ 1-8$.
} 


\begin{abstract}
"[...] se observarmos que na explosão da pólvora há desenvolvimento de calórico, entretanto que os elementos da mesma pólvora passam do estado de solidez, em que se achavam, ao estado gasoso, mediante a explosão. É verdade que o imortal Lavoisier, tendo em vista este mesmo fenômeno, supos que o ácido azótico [o ácido nítrico] fixando-se na sua combinação com a potassa, para a formação do nitro (um dos princípios ingredientes da pólvora) conserva a maior parte do calórico, que continha no seu precedente estado gasoso.

Mas esta suposição de Lavoisier, além de não ser fundada em nenhum outro fato, senão aquele mesmo que por ele se pretende explicar, é incompatível com a Téorica, tal como ela nos tem sido ensinada até o presente." (S2, 1, VII, 3-4, 1813).
\end{abstract}

Mas, a questáo comporta, ainda segundo Pinheiro Ferreira, o problema relativo à compreensão do "princípio" na passagem do ácido sólido ao gasoso na explosáo da pólvora, pois, tal como posto por Lavoisier - "há desenvolvimento do calórico, e que os elementos da mesma pólvora (corpo sólido) passando do estado de solidez em que se encontravam, para o estado gasoso" com a explosão -, não soluciona o problema, pois, "não só não tomam dos corpos ambientes calórico, fazendo com que eles esfriem; mas antes perdem uma tão considerável porção dele, que se manifesta na calorificação excessiva de tudo o que os cerca até uma notável distância". Daí, a tentativa silvestriana de tornar o "fenômeno da explosão da pólvora" compatível com os princípios da conhecida e "aliás incontestável teórica do calórico" (S2, 1, VII, 4-5, 1813).

Para fazer tal demonstração, Silvestre Pinheiro Ferreira partirá da 'teoria da definição’ que, nessa altura, julho de 1813 , já fora exposta nas suas Preleçóes Filosóficas, iniciadas em 26 de abril, como sendo parte do processo de 'entendimento' entre um homem que fala e outro que escuta, o que suscita ideias no ânimo de cada um deles, e, quanto maior forem as ideias comuns, maior será o entendimento que se faz ao se dizer o que se entende por uma determinada expressão que é desconhecida: "diz-lhe, refere-lhe, enumera-lhe as ideias que nele mesmo costuma suscitar aquela expressão, quando a ouve em semelhantes circunstâncias", este expediente, dirá Silvestre Pinheiro Ferreira, "chama-se definir", e, por isso, poderá concluir em seguida: "definir uma expressão é, enumerar as ideias comuns, que ela costuma suscitar em todos os que dela se servem em semelhante caso ${ }^{28}{ }^{28}$ E que, conforme é exposta em nota de rodapé ao texto de sua Memória, consiste

\footnotetext{
28 Cf. Preleçôes Filosóficas, \$34-35.
} 
no processo de enumerar ideias, despertadas "no ânimo de todos que delas se servem", sendo, portanto, necessário para definirmos uma palavra, "analisar o que se passa no espírito daqueles que dela se servem", donde podemos, ainda, inferir que "para uma mesma expressão, se podem fazer muitas análises; muitas podem ser as definiçóes: cada uma mais ou menos perfeita, segundo que a análise for mais ou menos bem feita" (S2, 1, VII, 5, 1813).

Desse modo, o calórico será, então, definido como algo que é entendido por "todos os químicos", como "uma substância, cujas partes exercitam todas, umas sobre as outras, uma repulsão indefinida", e donde devemos "deduzir todos os princípios, tanto os já conhecidos como os adicionais", que ele pensava faltarem à Teórica do Calórico, e "como todos concordam que o calórico dilata os corpos", este é o sentido da definição. E remetendo a nota de rodapé (1), na página 5 , àqueles químicos que negam ser o calórico uma substância, Pinheiro Ferreira, afirmará, ainda,

"Poderia parecer que desta generalidade deveriam exceptuar-se aqueles Químicos, que negam a existência de uma substância, a que só haja de dar o nome de Calórico: e na sua opiniáo esta palavra, bem como na opinião de todos a palavra atração, nada mais significa, do que um simples fato; isto é a dilatação dos corpos, que se dizem calefatos. Seria impróprio deste lugar o fazer ver que semelhante discrepância deriva unicamente da errada definição, que vulgarmente corre da palavra substância, pois que partindo da verdadeira definição, desaparecem, tanto esta, quanto inúmeras outras questôes, sobre serem as coisas, de que se trata, substâncias ou meras quantidades. Em umas Preleçôes Filosóficas, que faço atualmente imprimir, trato circunstanciadamente esta matéria" (S2, 1, VII, 5-6, 1813).

Portanto, admitindo-se tal definição, os corpos, na medida em que se aproximam do mínimo da "afinidade de agregação, se aproximarão igualmente da afinidade de combinação", donde, concluirá Pinheiro Ferreira que a primeira consequência derivada da definição dada é que "uma substância deve possuir a máxima afinidade de combinação para com todos e quaisquer corpos que se acharem em sua esfera de atividade" (S2, 1, VII, 6, 1813).

Por outro lado, se considerarmos que a afinidade de agregação das partes de um corpo entre si difere da que existe entre as partes de outro corpo, "segue-se que a afinidade de combinaçáo do calórico deve ser diferente para os diferentes corpos", e, independentemente de sua combinação com qualquer corpo, a força repulsiva das partes do mesmo calórico entre si há de ser aniquilada no todo ou em parte pela força de atração que existe entre as partes do corpo, com o qual 
ele estiver combinado. Se cada uma das partes de um corpo está reunida a todas as outras pela força da atração, essa "deve crescer na razão direta do número das partes componentes", donde segue-se que a soma das forças atrativas em um número qualquer de partes é menor quando elas estão separadas do que quando estavam unidas, pois, "que depois de separadas não existem senão as forças, que reúnem partículas de segunda ordem”, enquanto, quando estão juntas, existem também as partes que destas se compóem e se exercitam entre si.

Assim, quanto maior for uma força atrativa, tanto maior será a força repulsiva, que com ela terá de equilibrar-se, logo, dirá Silvestre Pinheiro Ferreira, "se as partes de um corpo reunidas tem maior soma de forças atrativas, do que separadas, hão de poder aniquilar no seu estado de reunião uma maior soma de forças repulsivas, ou háo de precisar de uma maior quantidade de Calórico para a sua saturação, do que estando separadas". A conclusão silvestriana será, entáo, a de que, quando as partes de um corpo se separam:

"[...] uma porção de Calórico, até agora retida pela força de atração, que perece pela simples fratura do corpo, obedecerá à força repulsiva das outras partes do mesmo Calórico, que ainda ficam combinadas com o corpo; e por conseguinte a aquecer todos os corpos ambientes. Não é pois unicamente pela solidificação que se desenvolve Calórico livre, como até ao presente se tem ensinado. Há, além deste, outro princípio de desenvolvimento de Calórico, que é a pulverização, como acabo de demonstrar.

Façamos aplicação deste novo princípio ao fenômeno da explosáo da pólvora, de que falamos ao princípio desta Memória" (S2, 1, VII, 7-8, 1813).

Ora, se nos voltássemos agora para o projeto d'O Patriota apresentado na Introdução do primeiro número, de janeiro de 1813, citado anteriormente, poderíamos confirmar que o autor desse texto mesclou muito habilmente, e de modo muito próximo às teses apresentadas por Pinheiro Ferreira publicadas em diferentes subscriçôes do próprio jornal, a "invenção das letras" com o "progresso das Ciências e das Artes”; a ação 'calórica' dos raios de sol que "dispersos aquecem os corpos duros, juntos em um foco derretem os mais duros metais"; a proposta dos sábios de "lançarem reciprocamente suas luzes para que da união delas resultasse aquele intenso calor, que vencesse a frieza da preguiça e a dureza da ignorância", ao projeto (contrário ao que havia sido o projeto primeiro, e, de certo modo, precário e fracassado, de colonização do Brasil) de 'politizaçáo' de uma 'terra', agora entendida como 'pátria', e outrora precariamente colonizada, e que, para não se perder, deve- 
ria assumir sua condição política, seja com a criação de um novo princípio de cidadania e de uma nova 'forma constitucional' capaz de garantir essas mudanças a partir de um programa 'filosoficamente' estruturado:

"Assim depois de vos ter dado em outras partes as definiçóes do Bom e do Mau: do Justo e do Injusto: do vício e da virtude, farei da Diceosina, ou do Tratado dos Direitos e Deveres do Homem e do Cidadáo, dos Estados e das Sociedades, o objeto de uma série de Preleçôes, que se bem serão interpoladas com outras de diferente assunto, formaráo entre si um corpo seguido de doutrina, que corresponderá, senáo no desempenho, ao menos no seguimento, aos desejos, que me haveis testemunhado." ${ }^{29}$

Ou seja, um projeto de nação cujo suporte seria o 'processo' no qual a literatura (no sentido largo a ela atribuído no século XIX) e a ciência produziriam a base substancial da ideia de nação, acrescida de um adjetivo que apontava para o tópos pátrio, isto é, para o solo que deverá ser chamado de 'brasileiro'.

Assim, ao retomar a tese de Lavoisier sobre o calórico, a intenção de Pinheiro Ferreira será: [i] explicitar um procedimento 'metódico' que já está sendo utilizado em suas Preleçóes Filosóficas, [ii] demonstrar como alguns impasses da "Teórica das Ciências" podem ser superados a partir da "Teoria da definição", que, igualmente, está sendo exposta em suas Preleçôes, e afirmar que, [iii], as condiçôes [i] e [ii] estão, por sua vez, articuladas com a "correta" definição de 'substância'30 (Cf. S2, 1, I, 3-7, 1813), e que, interpretadas à luz das Categorias

29 Cf. Preleçōes Filosóficas, $\$ 976$.

30 Para a discussão acerca do problema da 'substância', veja-se Preleçôes Filosóficas, $\$ 43$, \$71-106, onde na base da discussão silvestriana estará a tradução de oủ oía por "essência” e não por 'substância', no passo 2a11, das Categorias de Aristóteles, tal como na tradução latina aposta ao texto grego na edição de Isaac Casaubon, utilizada por Silvestre Pinheiro Ferreira em sua

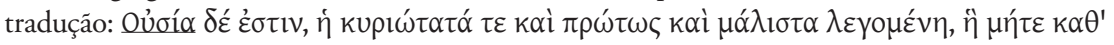

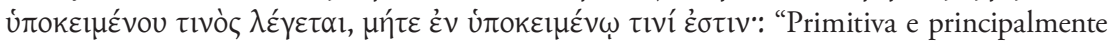
chama-se essência primária àquela, que nem se diz de nenhum objeto, nem está em nenhum objeto." (Cf. Aristóteles 1814: A.15; E.15, grifos nossos. A referência à tradução das Categorias será feita de acordo com a edição de Pinheiro Ferreira, que, propondo uma numeração própria, divide o texto em duas classes numeradas, os Aforismos e as Explicaçóes, aqui indicadas por A. e o número dado ao Aforismo, e, pelo E. e o número dado à Explicação). Talvez por isso tenha Pinheiro Ferreira, no $\$ 80$ das Preleçóes Filosóficas, chamado a atenção de seus leitores para a "extraordinária e perniciosa confusão que os Filósofos têm feito das palavras que acabamos de definir: e por essa razão julgo dever fixar mais no vosso espírito as verdadeiras noçóes delas, confrontando debaixo de um só golpe de vista o conteúdo destes últimos três parágrafos. Devemos portanto não perder jamais de vista, que a palavra corpo designa a reunião de algumas, ou de todas as qualidades referidas no $\$ .43$, ou sós, ou juntas a algumas outras, segundo o caso 
de Aristóteles, como veremos em seguida, são as chaves interlocutórias das Preleçôes Filosóficas, cujas 'luzes' atingirão, também, o modelo a partir do qual Pinheiro Ferreira irá estruturar o projeto político apresentado a D. João VI, em suas Memórias Politicas sobre os Abusos Gerais e Modo de os Reformar e Prevenir a Revolução Popular redigidas por Ordem do Principe Regente no Rio de Janeiro em 1814 e 1815, e dará a medida do modo como uma "naçáo se civiliza", ou seja, o modelo que os portugueses deveriam seguir na construção do Império do Brasil - antes que "este nascente Império do Brasil" que "já luta com as ânsias de uma infalível morte, se a mão de $\mathrm{V}$. A. R., por alguns poucos instantes poderosa, não acode a salvá-lo" 31 -, ou aquele modo ao qual os 'brasileiros' deveriam ter em conta, a partir de 1822, para construírem o seu 'Império do Brasil'. Portanto, o que pretendemos mostrar, já nessa primeira versão do pensamento de Pinheiro Ferreira, exposto no Brasil em suas Preleçóes Filosóficas e em O Patriota, é que a presença do pensamento antigo não se configura apenas como uma "legitimação de autoridade como sinal de controle de uma certa erudição"32, e, também, como "emulação para o presente com vistas ao futuro"33 , mas, como o esforço de pensar a 'gênese de uma nação' (ou, para usarmos o 'vocabulário' caro ao jornal, de uma 'pátria') e de alicerçar esse nascimento em uma forma de pensamento já estabelecida na tradiçấo ocidental: o pensamento grego. A originalidade da leitura e da interpretaçáo do pensamento antigo proposta por Pinheiro Ferreira está, acreditamos, no fato dessa hermenêutica tentar afastar-se das leituras religiosas - seja ela, a dos jesuítas ou dos oratorianos e que lhe foram contemporâneas -, buscando dela extrair uma nova compreensão para uma nova temporalidade (a migração da Corte portuguesa para o Brasil e as mudanças políticas daí advindas), sem entretanto, deconectar tal interpretação de suas raízes onde reside o fundamento do seu modo de ser e justifica o processo de 'transmigração de ideias' na construção da vida política.

de que se trata. Já por substância entende-se somente o complexo daquelas qualidades que se observam em qualquer estado possível. Por essência, porém unicamente o complexo daquelas qualidades atuais, a quem compete o epíteto de essenciais" (\$.72). Cf. também o comentário acerca das definições de 'essência' e 'substância', em Aristóteles, na 29ã Preleção.

31 Ferreira 1814(a).

32 Cf. Guimarães 2007: 75.

33 Idem, ibidem. 


\subsection{As Preleçóes Filosóficas e o modo como as naçóes se civilizam}

No ambiente eclesiástico no qual a filosofia foi sempre ensinada no Brasil Colônia ${ }^{34}$, as Preleçóes Filosóficas, de Silvestre Pinheiro Ferreira, são, efetivamente, uma conquista advinda da chegada da família real no Rio de Janeiro, em 1808, e que, acreditamos, deve ser, em primeiro lugar, compreendida no âmbito das mudanças introduzidas por D. João VI, e, dentre elas, a formação de uma Biblioteca Pública, a instauração das escolas profissionais - a Escola de Medicina, na Bahia, e a Escola Médico-Cirúrgica, no Rio de Janeiro -, a Real Academia Militar, o Horto Botânico, a Academia de Belas Artes, o Museu Nacional, a Aula Régia de Economia, o projeto do Instituto Acadêmico, e a instalação da Imprensão Régia que começa a funcionar ainda em 1808, portanto, em meio ao processo de montagem do Estado que daria ao Brasil o estatuto político de Reino, para, alguns anos mais à frente, estruturar as bases de um Império.

As Preleçôes Filosóficas foram proferidas no Real Colégio de São Joaquim, ${ }^{35} \mathrm{e}$, embora as datas de início e fim não tenham sido claramente definidas pelos historiadores, temos notícia, pelo anúncio publicado na Gazeta do Rio de Janeiro, de 13 de abril de 1813, do programa e do seu início no dia 26 de abril, acrescentando-se, ainda, que aqueles que "quiserem subscrever para estas Preleçôes, que serão nas segundas, quartas e sextas feiras pelas 5 horas da tarde, dirigir-se-âo ao Reverendo Reitor do mesmo Colégio de S. Joaquim", e que a "subscrição é de meia dobla ao mês"; bem como, a informação veiculada por $O$ Patriota, na S1,4,IV,92-93,1813, de que no dia 26 de abril Pinheiro Ferreira teria feito sua primeira Preleção, e que as teria prorrogado até o dia 18 de maio: "No dia 26 do corrente recitou o Sábio Professor um eloquente discurso sobre as matérias acima enunciadas, onde

34 Antes da vinda de D. João VI, e após a expulsão dos jesuítas pelo Marquês de Pombal, em 1759, o estudo da filosofia entre nós ficaria quase inteiramente restrito aos Seminários, que nem sempre adequaram seu ensino às normas pombalinas; e as denúncias feitas pelos Professores Régios nomeados parecem sublinhar a influência do ensino religioso, quando relatam que ensinavam ao público a filosofia proscrita pela reforma, "em umas apostilas peripatéticas cheias de questôes escuras e inúteis que servem de arruinar e fazer perder o gosto aos bons estudos". Apud Sucupira 1976: 360. Cf. também a polêmica entre os professores régios de latim nomeados para Pernambuco apresentada no Apêndice do livro de Laerte Ramos de Carvalho, As reformas pombalinas da instrução pública, 1978: 193-229.

35 Que se transformaria posteriormente no Colégio Pedro II. 
brilharam os princípios filosóficos que o distinguem, e prorrogou as suas Preleçôes para o dia 18 de Maio".

Quanto ao seu término, as datas são também controversas, mas é quase certo que tenham se prolongado, no mínimo, até o final de 1815, como sugere Antonio Paim, na introdução da edição por ele organizada das Preleçôes Filosóficas ${ }^{36}$, ou como podemos inferir, a partir da informação que nos é dada por Luis Joaquim dos Santos Marrocos, em Carta de 23 de fevereiro de 1816, onde em uma de suas caústicas referências a Pinheiro Ferreira afirma:

\begin{abstract}
"Silvestre Pinheiro, no tempo em que esteve suspenso de seus lugares, ocupou-se em ensinar Filosofia por um método mui amplo e générico, que abrangia todos os seus ramos: julgo que suas intençôes lhe sairam difíceis na prática, do que havia concebido, porque enfim são proposições à Francesa. Tem publicado alguns folhetos de suas Preleções e não sei se ainda continuará, de cuja Coleção remeterei a V. M. um exemplar, como me recomenda; e na introdução se conhece a verdade do que digo acima." ${ }^{37}$
\end{abstract}

Se for correto o que diz Marrocos, as Preleçóes teriam sido ministradas até 1815, quando Pinheiro Ferreira passa a integrar a Direção da Real Tipografia.

Quanto a sua publicação em fascículos, pela Impressão Régia, no Rio de Janeiro, a partir de 1813, a carta de Marrocos parece também confirmar, bem como, a mesma Gazeta do Rio de Janeiro, em 28 de agosto de 1813, noticia a publicação da Primeira Preleção, que poderia ser comprada por $200 \$ 00$, na loja da Gazeta e na de Francisco Luiz Saturnino. Uma outra indicação que nos permite inferir a publicação seriada está na "Advertência"

\footnotetext{
36 Cf. Paim 1970: 7.

37 Luis Joaquim dos Santos Marrocos chegou ao Rio de Janeiro em 1811, juntamente com a segunda remessa dos livros da Real Biblioteca. Em Lisboa, havia servido como ajudante das Reais Bibliotecas, desde 1802, e, no Rio de Janeiro, serviu na Real Biblioteca, trabalhando junto ao Padre Joaquim Damásio e, em setembro de 1811, foi nomeado pelo Princípe Regente responsável pelo "arranjamento e conservaçáo dos Manuscritos da Coroa, que S. A. R. determinava permanecessem junto à sua pessoa, e dos mais papéis que ordenasse para o futuro" (Garcia 1934: 9). Suas cartas à família, escritas entre 1811-1821, estão arquivadas na Biblioteca da Ajuda, em Lisboa, e foram editadas por Rodolfo Garcia, nos Anais da Biblioteca Nacional do Rio de Janeiro, v. 56, de 1934, a partir de cópias autênticas, obtidas pela intervenção de Luiz Edmundo. As cartas também foram parcialmente reeditadas nos Cadernos da Biblioteca Nacional, v. 4, com o título O Bibliotecário do Rei - Trechos selecionados das cartas de Luis Joaquim do Santos Marrocos, no Rio de Janeiro, em 2007. Cf. Carta 98, da edição de Rodolfo Garcia, 1934: 266-267. Os grifos são nossos.
} 


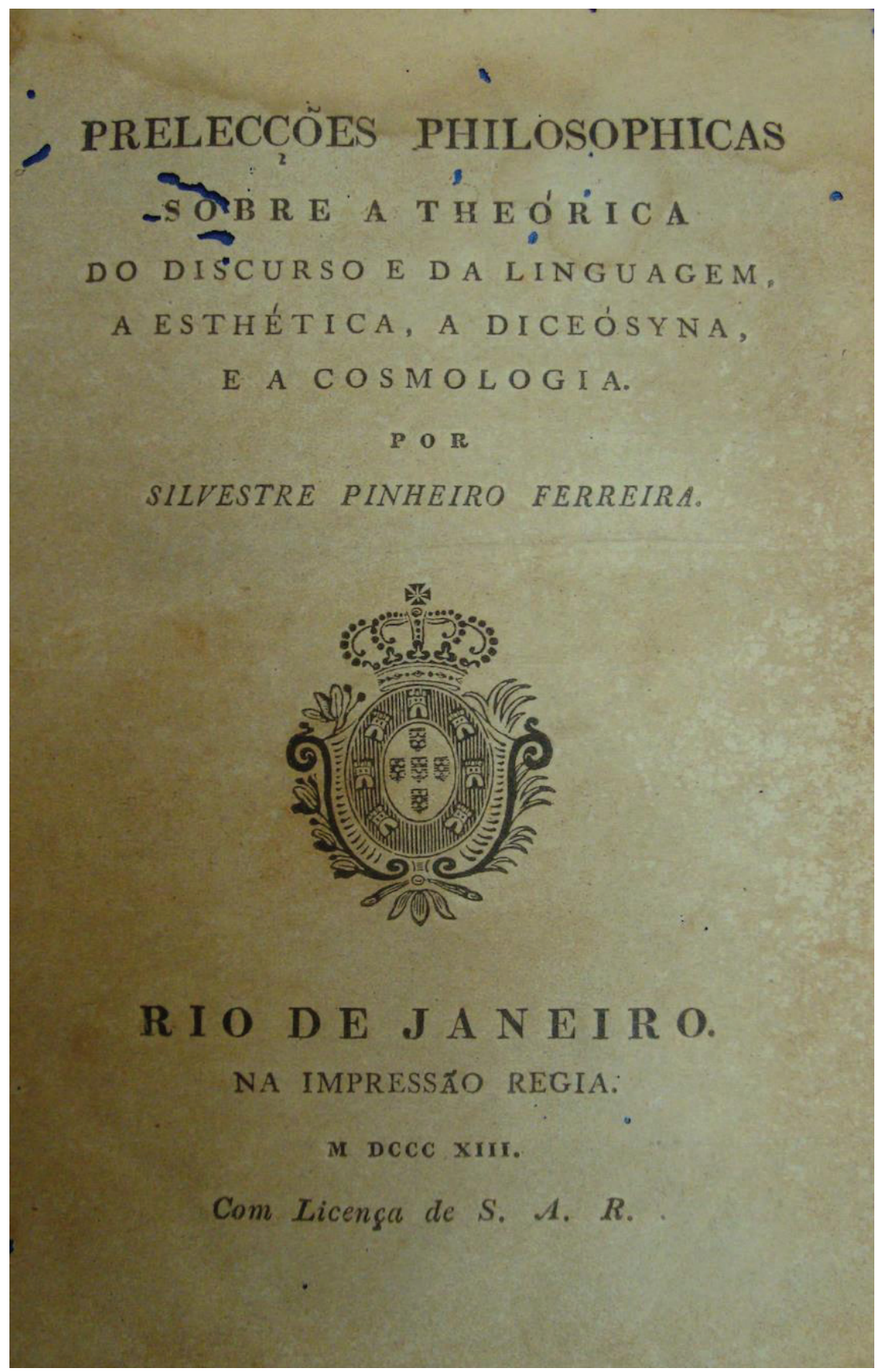

Folha-de-rosto das Preleçôes Filosóficas (Acervo da Fundação Biblioteca Nacional, Rio de Janeiro) 
que aparece logo após a folha de rosto da tradução das Categorias: "Uma das partes mais essenciais do Curso de Preleçōes Filosóficas, que estou atualmente publicando...”. Ou, ainda, a nota em O Patriota, S2, 3, IX, 1813, anunciando as obras publicadas, em agosto de 1813, na Corte, nos fala da publicação das Preleçôes Filosóficas, e, pelo resumo ali apresentado, parece referir-se à publicação da $1^{a}$ Preleção:

"Obras publicadas nesta Corte no mês de Agosto.

Preleçóes Filosóficas sobre a teórica do Discurso e da Linguagem, a Estética, a Diceósina e a Cosmologia. Por Silvestre Pinheiro Ferreira.

O A., cujos talentos são tão justamente acreditados, dá primeiro uma ideia geral da Obra, reduzindo a três objetos das suas Preleçóes, a saber, a teórica do Discurso e Linguagem, o tratado das paixóes, e o sitema do Mundo: no $1^{\circ}$ expóe os princípios da Lógica, da Gramática Geral e da Retórica; no $2^{\circ}$ considera as paixôes ou como simples sensações, ou como atos morais: da primeira consideração nascem a Estética, a Poesia, e as Belas Artes, e a segunda produz a Diceósina: debaixo da denominação da Cosmologia, involve a Ontologia, e a nomenclatura das Ciências matemáticas e físicas, e daí deduz os princípios da Teologia Natural." (S2, 3, IX,79, 1813)

Por outro lado, o Correio Braziliense, de Hipólito da Costa, informa, no exemplar de outubro de 1814, o aparecimento das oito primeiras Preleçóes, e, no número de agosto de 1816, informa aos seus leitores as publicaçôes da Nona à Vigésima Preleção ${ }^{38}$. Parece, então, razoável a indicação de Rodolfo Garcia, na nota 45 de sua edição das Cartas de Marrocos, de que a publicação da obra foi iniciada em 1813, que em 1816 apareceu a 23a Preleção, em 1818 da $26^{a}$ à $29^{a}$ Preleção, e, em 1820, a 30a Preleção, que foi a última a ser impressa. ${ }^{39}$ A versão hoje conhecida das Preleçóes Filosóficas, em um único volume, com a folha-de-rosto indicando 1813 como ano de publicação, provavelmente deve ser o resultado da encadernação de todos os fascículos "capeados" pela folha de rosto publicada com o primeiro fascículo, com o Índice das Vinte e duas

38 As críticas que Hipólito da Costa fará às Preleçôes serão refutadas por Silvestre Pinheiro Ferreira na Décima Oitava Preleção, a partir do $\$ 590$, o que nos permite supor que só devem ter sido redigidas no final de 1814. Observamos, entretanto, que esta informação publicada pelo Correio Brasiliense, em agosto de 1816, nos permite indagar se o curso náo se prolongou para além de 1815 .

39

Cf. Garcia 1934: 267. 
primeiras Preleções, com a indicação de Tomo I, Parte I, acrescida de um Suplemento, com paginação própria, o Índice contido nas páginas 1 até à 89, e o Suplemento, nas páginas 90 até à $101 .{ }^{40}$

Ora, se seguirmos as indicaçóes publicadas em abril de 1813, na primeira subscrição de $O$ Patriota, como citado anteriormente, e, se nos ativermos às "Advertências" do autor, contidas na sequência das folhas-de-rosto das Preleçóes Filosóficas e da tradução das Categorias, veremos que seu projeto, além de educativo e filosófico, contém, claramente demarcada, uma estratégia política, delimitadora de um Estado e de uma nação, que deve estar subscrita na tradição do pensamento antigo, e, sob essa ótica a escolha do texto aristotélico pode ser lida em múltiplas dimensôes: da crítica aos jesuítas e, de certo modo, aos oratorianos - sublinhando aí a redefinição da tradição aristotélica portuguesa -, à crítica a Arnault e à escola de Port-Royal em suas

40 A Biblioteca Nacional do Rio de Janeiro possui parte da edição em fascículos, e uma edição quase completa, faltando apenas a 30a Preleção, mas contendo o Índice e o Suplemento ao Índice, e encadernada juntamente com as Preleçôes Filosóficas, encontramos a edição de 1814, pela Impressão Régia, da tradução de Pinheiro Ferreira das Categorias de Aristóteles (cf. FBN - 37,0,5,N1 e FBN - 37,0,5,N2), pertencente à Coleção Benedito Ottoni, que é composta pela biblioteca de José Carlos Rodrigues, colecionador e bibliófilo que, ao ser posta à venda, foi adquirida por Júlio Benedito Ottoni, que a doou integralmente à Biblioteca Nacional, e, em 1911, foi incluída no acervo da FBN. Como podemos observar nos fascículos pertencentes à $\mathrm{FBN}$, a paginação dos fascículos foi progressiva, daí sua aparente natural integração em um único volume. $\mathrm{O}$ fascículo referente à $7^{a}$ Preleção, no acervo da FBN, tem início na página 73 e fim na página 90, com carimbo da Real Biblioteca nas páginas 75 e 90, o que significaria, segundo informação da Profa. Ana Virgínia Pinheiro, Chefe da Seção de Obras Raras, da FBN, o início da obra (com o carimbo da Real Biblioteca no primeiro espaço em branco depois da folha-de-rosto) e o seu fim, com o carimbo no final do texto. Portanto, parece muito provável que os fascículos assim paginados tenham sido encadernados em uma única obra, tal como podemos consultar no acervo da Biblioteca Geral da Universidade de Coimbra, e no exemplar pertencente à Coleção D. Carolina Michaelis de Vasconcelos, do Instituto de Estudos Românicos, da Faculdade de Letras da Universidade de Coimbra, na qual a edição das Categorias está também encadernada em conjunto com as Preleçôes. Vale observar, ainda, que o Real Gabinete Português de Leitura, no Rio de Janeiro, possui as nove primeiras Preleçôes, com paginação progressiva e que no final da obra de Silvestre Pinheiro Ferreira, Noçóes elementares de Filosofia geral e aplicada as ciências morais e politicas: ontologia, psicologia, ideologia, publicada em Paris, em 1839, também pertencente ao acervo do Real Gabinete, encontramos, na enumeração das obras do autor, a indicação das Preleçôes Filosóficas, impressas no Rio de Janeiro, em 1813, 1 v. $4^{\circ}, 5$ fr., que também nos sugere a posterior encadernação dos fascículos com a folha-de-rosto do primeiro fascículo impresso em 1813. Outro dado que parece, também, confirmar tal sugestão é a observação manuscrita por Joaquim Vasconcelos na folha-de-rosto do exemplar da Coleçáo Carolina Michaelis de Vasconcelos: "Ediçôes raras que de modo nenhum se devam emprestar". O plural tanto pode valer para a conjunção das Preleçōes Filosóficas com a tradução das Categorias, quanto para o conjunto dos fascículos, e, ainda, para ambos. 
objeçóes ao autor das Categorias, e mesmo ao pensamento que lhe é contemporâneo, na segunda metade do século XVIII (na crítica a Condillac e Desttut de Tracy, por exemplo) e na primeira metade do século XIX. Dessas críticas, nasce, acreditamos, uma leitura muito arguta do pensamento antigo, que continuará presente no processo de independência do Brasil, sobretudo no modelo político-constitucional pensado por José Bonifácio de Andrada e Silva, e que, com novas modalidades, reapareceria no governo de D.Pedro II.

A estruturação das Preleçóes pretende, assim, abarcar o domínio que Pinheiro Ferreira compreende como o da Filosofia - entendida por ele como sendo o estudo dos "fatos comuns a todas as Ciências" ${ }^{\text {"ł1 }}$ - e de sua disposição na ordem do pensamento, observada em um contexto metódico, delimitado pelo autor na forma que se segue: [i] a teórica do discurso e da linguagem, onde serão expostos os princípios que regem a Lógica, a Gramática e a Retórica, como base do processo inteligível; [ii] o tratado das paixôes consideradas primeiro como sensaçóes, para em seguida tratar das questóes relativas ao "gosto", daí determinando as regras da estética, da retórica, da poesia e das belas artes, que, compreendidas como "atos morais", exigem a compreensão das ideias de virtude e vício, donde serão inferidas "as máximas da Diceósina, que abrangerá a Ética e o Direito Natural”; e [iii] a cosmologia, o sistema do mundo, onde tratar-se-á das propriedades gerais dos entes, da nomenclatura das ciências físicas e matemáticas, e dos princípios da teologia natural.

O autor esclarecerá ainda, na apresentação da "Idéia Geral da Obra", que, uma vez estabelecidos os necessários princípios preliminares da Teórica - o que será feito nas oito primeiras Preleçóes -, as duas outras partes mencionadas acima serão acompanhadas pela análise de "alguma obra escolhida dos principais Filósofos, Oradores e Poetas, assim antigos, como modernos, sagrados, e profanos". ${ }^{42}$

A partir da 9a Preleção Silvestre Pinheiro Ferreira começará, então, seus comentários às Categorias, de Aristóteles, procurando, simultaneamente, demonstrar o que há de semelhante e o que há de diferente no que tange à matéria filosófica, entre sua concepção da filosofia e a daqueles "escritores que o precederam, começando pelos antigos até os modernos". ${ }^{43}$

41 Cf. Preleçôes Filosóficas, $\$$ 20: "Eu disse que há fatos comuns a todas as Ciências, e que estes são do alcance da Filosofia. Isto me conduz a observar que as Ciências ou têm por objeto as faculdades do Espírito, ou as propriedades dos Corpos."

42 Preleçōes Filosóficas, f.1, 1813.

43 Cf. Preleçóes Filosóficas, $\$ 310$. 
O comentário ao texto de Aristóteles estender-se-á até à 29a Preleção, para, então, na 30a Preleçâo, dar início à discussão acerca da questão da ideia do Bom e do Mau, onde o autor descreverá o modo "como as naçóes se civilizam e avançam em bom gosto, podendo ao mesmo tempo crescer em forças e riqueza ou decair em desfalecimento e pobreza", e nesse contexto, mostrará, ainda, como as relaçóes políticas entre as naçóes devem se estabelecer em níveis de amizade e de comércio, delimitando os modos como essas relaçôes devem se conformar. ${ }^{44}$

Nesse sentido, tanto o tratado das paixóes, quanto o sistema de mundo terâo de ser pensados à luz da teórica do discurso e da linguagem, e se a "arte de pensar" e a "arte de falar" sáo indissociáveis, uma vez que,

"Todo homem, qualquer que seja o seu estado e profissáo, precisa de saber discorrer com acerto e falar com correção. Todos precisam de conhecer o Mundo, tanto o físico como o moral, de que fazem parte, isto é, as Leis gerais dos corpos, que compõem o Sistema do Mundo; e os Deveres que cada um de nós, considerado como homem e como cidadão, tem para consigo mesmo para com a sociedade, e para com o Ente Supremo, de quem havemos recebido a existência". ${ }^{45}$

os verdadeiros filósofos assentam suas doutrinas sobre a compreensão de que a "teórica do raciocínio e a do discurso é inseparável da teórica da linguagem". 46

O 'método' aí empregado envolve, assim, um primeiro conjunto de definiçôes, a sua clarificação na análise do texto filosófico - no caso, as Categorias, de Aristóteles -, e a estratégia de sua aplicação aos diversos níveis da reflexão filosófica de tal modo que possamos compreender a filo-

\footnotetext{
44 Preleçôes Filosóficas, $\$ 985$ e seguintes.

45 Preleçōes Filosóficas, $\$ 1$.

46 Cf. Preleçóes Filosóficas, $\$ 5$ e $\$ 8$, onde já criticando tanto a escolástica dos jesuítas - que na Ratio Studiorum negavam à retórica o estatuto filosófico -, quanto a crítica a Aristóteles da escola de Port-Royal, Pinheiro Ferreira afirma: "Houve um tempo em que os Filósofos julgaram que assim como dos vestidos, com que nos cobrimos, o que os corta e cose, nada cura de saber como se tecem e urdem; [...] do mesmo modo cumpria que aquele que ensinasse a Arte de pensar, ou a Lógica, se não intrometesse com as regras da Arte de falar, quero dizer da Gramática Geral e da Retórica. Donde resultou que estas duas últimas Ciências repudiadas pelos Filósofos, como que também da sua parte prescindiram da Filosofia; de modo que contentes com saberem o que haviam os Mestres mais acreditados (que nem sempre foram os mais sensatos) os Gramáticos e os Retóricos, pela maior parte, reputavam estranho à sua profissão o exame filosófico dos princípios da Arte que ensinavam.”
} 
sofia como uma espécie de "gramática universal", que nos permite o conhecimento dos princípios das ciências. Valendo, ainda, acrescentar que a essa disposição metódica o autor impóe uma apresentação didática e racional, na qual cada uma das trinta preleçóes está ordenada em parágrafos, apresentados em numeração progressiva e antecedidos todos pelo item "Assunto", em cada uma delas, onde encontra-se explicitado o seu tema, o seu assunto.

Entretanto, se também levarmos em conta as palavras contidas nas "Advertências" que o autor faz aos seus leitores e ouvintes, após a folha-de-rosto da $1^{a}$ Preleção, veremos que essa disposição metódica parece estar incluída em um contexto que prenuncia seu projeto político de conformação de um 'novo estado', uma nova 'ordem política', ou talvez, já pudéssemos sugerir, de um novo império, o "império do Brasil”, que terá sua conformação concluída anos mais tarde, em uma clara continuação da 30a Preleção, nas obras Observaçôes sobre a Constituição do Império do Brasil e sobre a Carta Constitucional do Reino de Portugal, e, no Manual do Cidadão em um Governo Representativo.

Ora, se o exercício da filosofia está, para Silvestre Pinheiro Ferreira, entre os "azares da fortuna" - que marca o tópos político no qual ela se realiza -, e os "reveses da ventura" - que a filosofia como "profissão" e "constância sobranceira" acarretou ao longo de sua vida -, como justificativa de sua proposta das Preleçóes Filosóficas,

"Azares da fortuna, cuja relaçáo pertence a outro lugar, me levaram a consagrar à instruçâo da Mocidade os momentos desocupados dos deveres próprios do Emprego, que exercito no serviço do Estado.

Era natural, que tendo de recorrer no último quartel da vida à mesma honrosa Profissão, com que nos anos da juventude abri a minha carreira no mundo literário, me valesse daquela Ciência, a quem devi sustentaçáo, amigos, e constância sobranceira e todos os reveses da ventura. Resolvi-me pois a anunciar nesta Corte um Curso de Preleçôes Filosóficas sobre a Teórica do Discurso e da Linguagem, a Estética, a Diceósina e a Cosmologia., ${ }^{\prime 7}$

as dificuldades para a execução dessa tarefa implicam na elaboração de um "Livro elementar" que pudesse "fixar" e "recordar" nos ânimos de seus ouvintes o que nelas houvesse sido abordado. Daí a idéia das cópias, seja pela cópia manual dos alunos, seja pelo uso dos prelos!

47 Preleçóes Filosóficas, Advertência, f. 3, 1813. Grifos nossos. 
"Mas opunha-se à execução deste projeto a falta de um livro elementar, cuja liçâo fixasse e recordasse nos ânimos dos que assistissem às Preleções, as doutrinas de que nelas se houvesse tratado.

Não me restava outro recurso, senão o de pôr eu mesmo por escrito as próprias Preleçóes: e deixar tirar cópias delas aos meus ouvintes, ou fornecer-lhas por via da Impressão.

A este último expediente porém, que era sem dúvida o mais acertado encontrava a regra geral de se não deverem entregar ao Prelo, senão Obras trabalhadas com descanso, perfeitas e acabadas.

Contudo pareceu-me, que esta regra admitia algumas exceçóes, era certamente uma delas o caso em que eu me achava, absolutamente destituído de Elementos para o uso das minhas Leituras.

É pois esta urgência, e não cegueira de amor próprio, quem me move a deixar sair à luz estas Preleçóes com os numerosos defeitos, que são de esperar de obra, que deve ser composta, revista pelas competentes Autoridades, e impressa no curto espaço, que medeia entre Leitura e Leitura". ${ }^{48}$

Portanto, o filósofo nos adverte que, em meio às dificuldades de ordens diversas, superá-las significa estabelecer em uma "ciência" a indissociabilidade entre a "arte de falar" e a "arte de pensar", e que tal "ciência" estará assim conformada pelos 'elementos' que compóem o novo estatuto político do Brasil: a implementação da tipografia e a laicização da filosofia. O livro, como substrato material da reflexão filosófica, tem um alcance mais largo, pois, como 'elemento', pode forjar um 'sistema' a partir do qual as categorias que explicitam os 'objetos' e as 'palavras' legitimam o processo no qual o Brasil se civiliza. ${ }^{49}$

Agora, então, podemos perguntar: qual a função da tradução das Categorias neste contexto? Não seria mais uma vez um modo de Silvestre Pinheiro Ferreira articular a arte de pensar com a arte de falar? Não cumpriria ela a função de estabelecer os princípios que regem as condições precárias, mas legítimas, do processo denominado na 30a Preleção de "como as naçôes se civilizam e avançam em bom gosto"?

48 Preleçôes Filosóficas, Advertência, f. 3 e 4, 1813. Grifos nossos.

49 Aqui vale lembrar a definição que nos é dada de 'elemento': "qualquer das partes componentes de um Sistema”; e a tradução de Pinheiro Ferreira para $\tau \tilde{\omega} v$ őv $\tau \omega \nu \tau \hat{\alpha} \mu \dot{\varepsilon} v$

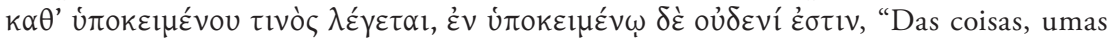
dizem-se de algum objeto; mas não estão em nenhum objeto”. Cf. Categorias, A.5. 


\subsection{As Categorias, de Aristóteles, a funçáo da traduçáo e o projeto de uma nação brasileira}

A tradução das Categorias de Aristóteles foi publicada em 1814, com folha-de-rosto e paginação próprias, embora em alguns exemplares esteja encadernada com as Preleçóes Filosóficas, em um único volume - como no caso do exemplar da Biblioteca Nacional do Rio de Janeiro, bem como do volume pertencente à Coleçáo Carolina Michaelis, do Instituto de Estudos Românicos, da Faculdade de Letras da Universidade de Coimbra. ${ }^{50}$

A folha-de-rosto já nos indica que o projeto de tradução abarca objetivos peculiares ao autor das Preleçôes, pois seu modo de traduzir está consubstanciado em uma intervençáo direta no original grego: Categorias, de Aristóteles; "traduzidas do grego e ordenadas conforme um novo plano", concebido por ele, "para uso das Preleçóes Filosóficas do mesmo tradutor".

Assim, procurando dar ao texto de Aristóteles uma feição semelhante àquela utilizada na elaboração das Preleçôes Filosóficas, isto é, o de ser um "Livro elementar", Silvestre Pinheiro Ferreira vai dividir o texto das Categorias em duas partes: uma primeira, denominada Aforismos, e a segunda, chamada de Explicaçóes, e contendo, cada uma, paginaçáo própria e progressiva; o autor justificará sua escolha na apresentação do texto da tradução em função da tese, já demonstrada nas Preleçôes Filosóficas, de que a alteração da ordem da escrita em nada altera a ordem das idéias ou a da leitura:

"Mas se não precisa de justificação a homenagem que assim tributo às Obras de Aristóteles; precisa-o tanto mais a novidade da forma, em que aparecem na presente tradução: novidade, que deve parecer à primeira vista; um total transtorno do texto do Autor. Porém este transtorno, que é na verdade grande quanto à ordem da escrita, em nada altera, nem a ordem das idéias, nem a da leitura. Porquanto se começando nós a ler o texto da Primeira Parte pela primeira palavra Equivocos (que é também a primeira do original) passarmos da palavra diferente à Explicação No 1, na Segunda Parte: e lida ela, voltarmos ao segundo $₫$ da Primeira Parte: Univocos porém etc.: e assim continuarmos, passando alternativamente do Texto às Explicaçóes, que os números, ou os asteriscos indicam: e destas ao Texto; ninguém que

50 Sobre essas ediçóes veja-se a nota 41. Vale observar ainda que a Biblioteca Nacional de Portugal possui um exemplar contendo apenas as primeiras vinte e três preleçóes. 


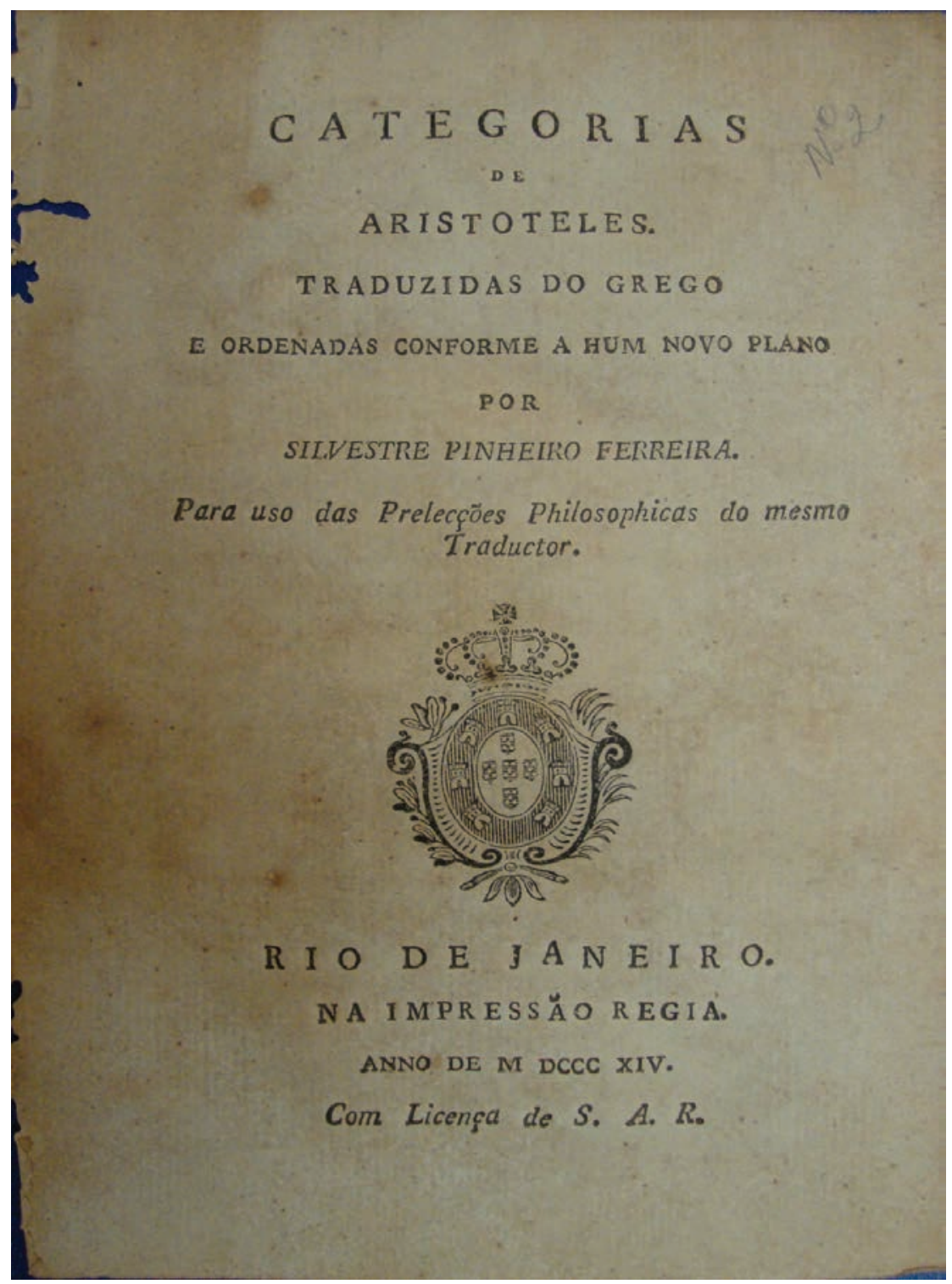

Folha-de-rosto da tradução de Silvestre Pinheiro Ferreira, diretamente do grego, das Categorias, de Aristóteles, publicada no Rio de Janeiro, pela Impressão Régia, em 1814. Trata-se da primeira publicaçáo, no Brasil, de um texto do pensamento antigo (Acervo da Fundaçáo Biblioteca Nacional, Rio de Janeiro). 
Politeía Tropical: a recepção dos clássicos, a tradição política no Brasil do século XIX e a tradução das Categorias aristotélicas por Silvestre Pinheiro Ferreira

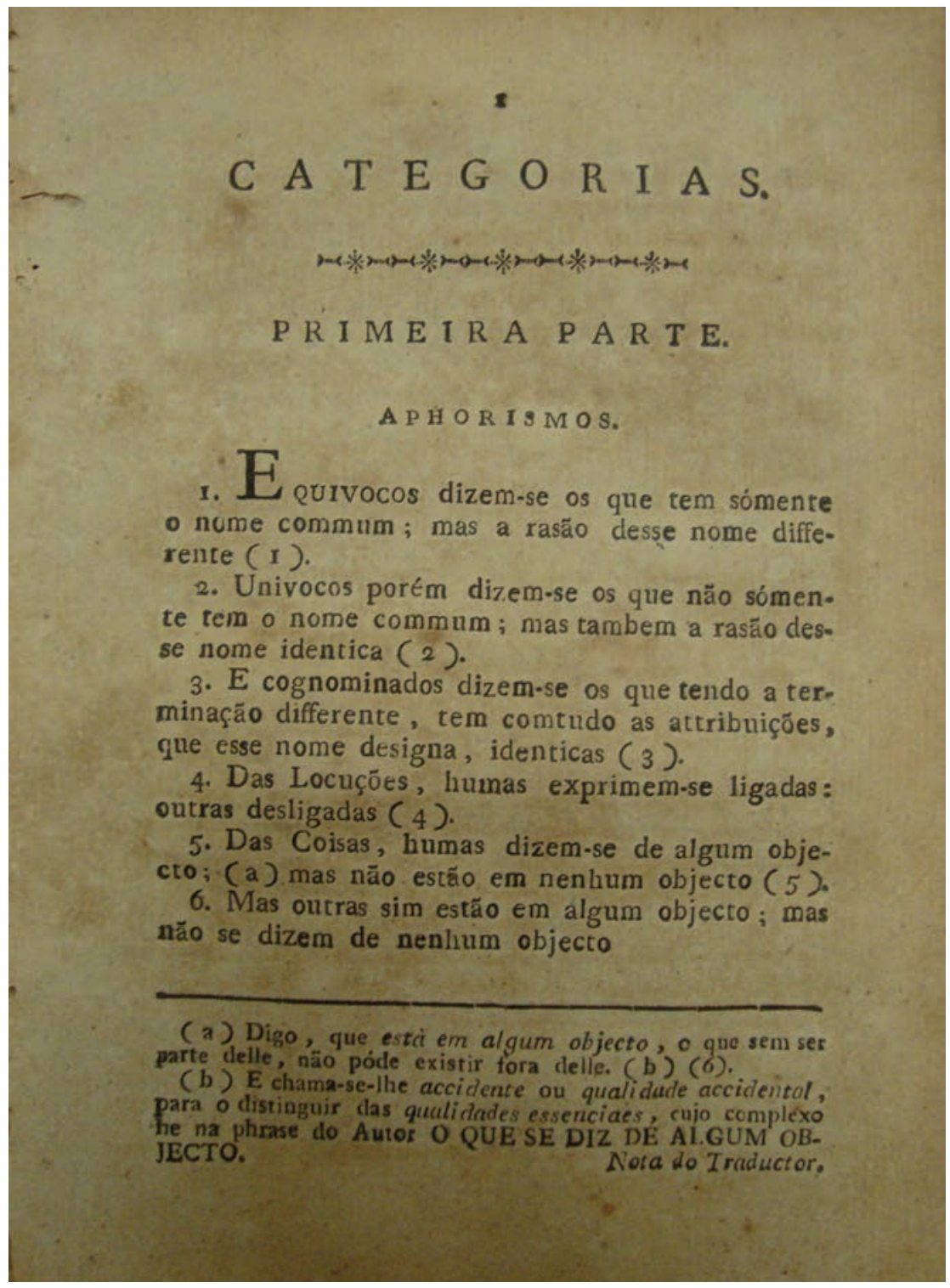

Categorias - Primeira parte chamada por Silvestre Pinheiro Ferreira de Aforismos. (Acervo da Fundação Biblioteca Nacional, Rio de Janeiro) 


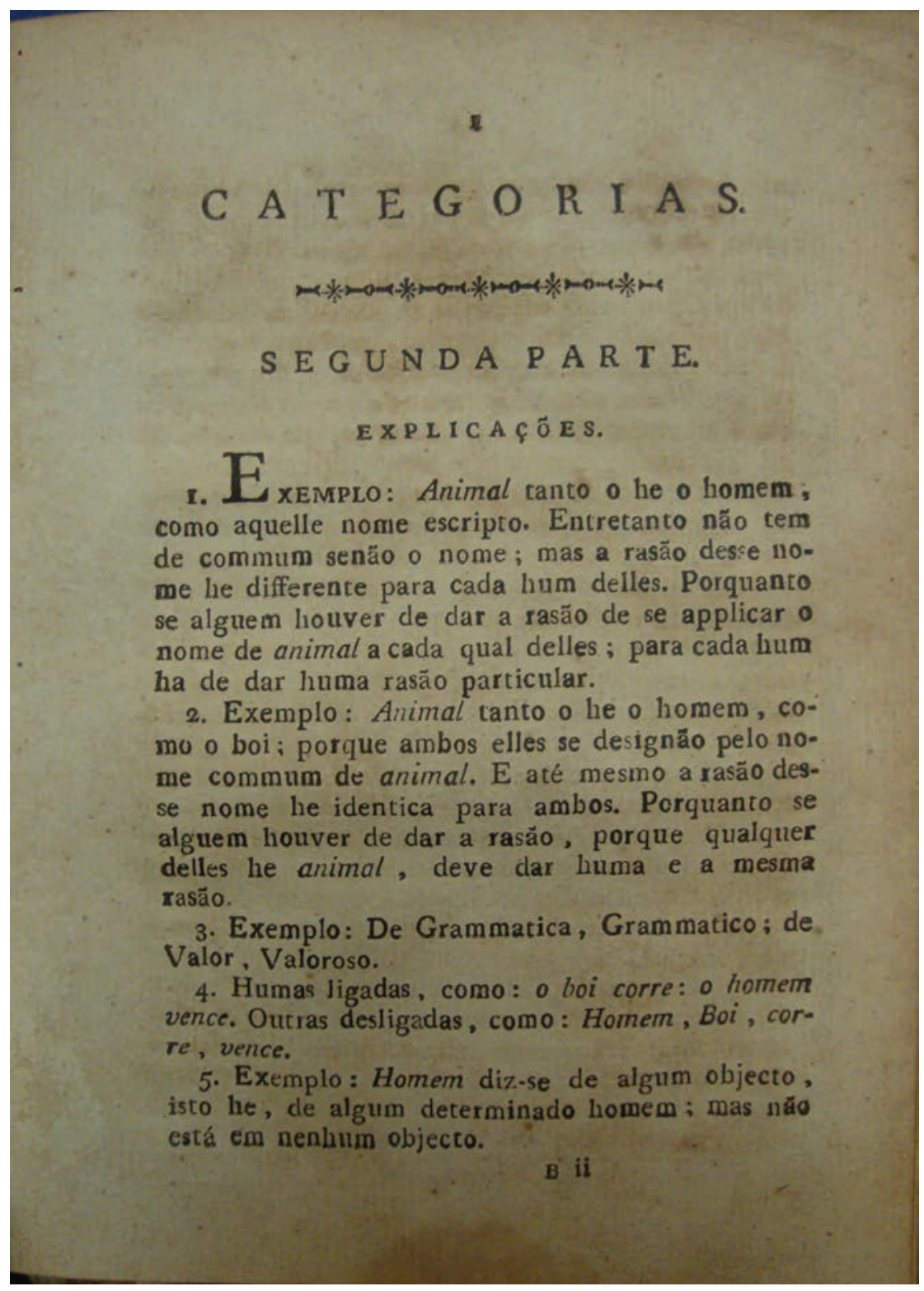

Categorias - Segunda parte chamada por Silvestre Pinheiro Ferreira de Explicaçōes. (Acervo da Fundaçấo Biblioteca Nacional, Rio de Janeiro) 
com os olhos no Original grego nos escutasse, poderia suspeitar que nele se houvesse feito a menor alteração." ${ }^{51}$

Ao dividir o texto original em Aforismos e Explicaçôes, nosso autor está atuando com a mesma "teórica das definiçôes" já utilizada nos artigos publicados em $O$ Patriota e metodicamente explicitada nas Preleçóes Filosóficas. Para tanto, parece-nos oportuno lembrar a etimologia do termo 'aforismo', do grego aphorismós, que tanto pode ser traduzido por 'definição', quanto por 'determinação', 'delimitação', e, também, como 'separação', 'distinção', portanto, a ação verbal, aphorizo, adjunta ao substantivo masculino aphorismós, consiste em definir, determinar, delimitar, separar e distinguir, sentidos que encontraremos nos textos aristotélicos - por exemplo, na Retórica, 1354a3; na Política, 1331a27; e nas próprias Categorias, 3b 20 e 3b 22; 5b 12 -, e que será traduzido por Pinheiro Ferreira em suas ocorrências nas Categorias, por 'determinaçáo..$^{2}$ Desse modo, a "novidade da forma" adotada na traduçáo parece perfeitamente consonante com as teses silvestrianas que, de certo modo, assimilam aspectos importantes de sua interpretação das Categorias.

O texto grego utilizado por Pinheiro Ferreira, como indicado ao final da "Advertência", foi o de Isaac Casaubon, editado em 1596, em Lyon, pela Oficina de Jacob Bubon, em dois volumes, in folio, contendo a Obra de Aristóteles em grego, e com a tradução para o Latim, feita por Gourchy ${ }^{53}$, e se voltássemos os nossos olhos para a tradução, como nos sugere Pinheiro Ferreira, e fizéssemos a colação do texto de grego com a tradução dividida em Aforismos e a Explicações, teríamos o quadro seguinte:

51 Ferreira 1814: f.3-4. Grifos nossos. Além da "novidade da forma” a tradução contém um modo próprio de referenciar o texto, pela numeração progressiva dos Aforismos e das Explicaçôes, em um momento em que não temos ainda a edição de Bekker, publicada em Berlim, em 1831 (Aristotelis opera, ex recensione Immanuelis Bekkeri, Ed. Academia regia Borussica, t. I, Berlin, 1831.)

52 Cf. Liddell, Scott, Jones, s.v. ’’ $\varphi$ opí $\omega$. Cf. a tradução silvestriana para os passos 3b 20: "Assim que, tanto a espécie, como o gênero, determinam as qualidades das essências;"

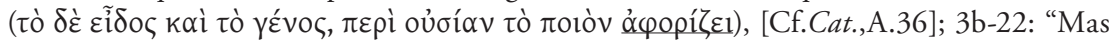

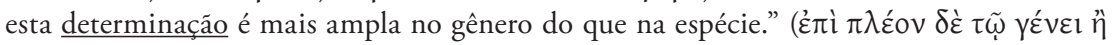

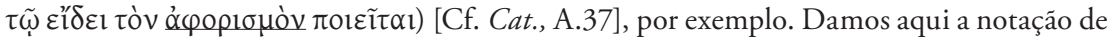
Bekker e entre colchetes a de Silvestre Pinheiro Ferreira, de tal modo que a referência fique facilmente acessível. O texto grego citado será sempre o de Isaac Casaubon.

53 Cf. Casaubon, 1590: 2 e Schmitt 1992: 92 que afirma ter Casaubon incluído em sua edição a tradução de Grouchy do Organon de Aristóteles, abandonando a tradicional versão latina de Párion. 


\section{$<$ [KАТНГОРIAI] $>$}

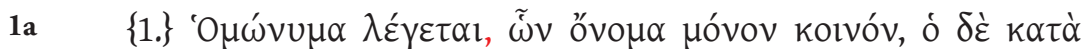

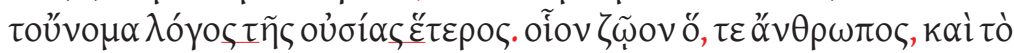

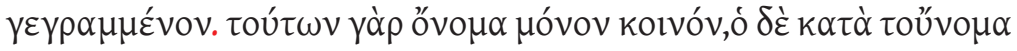

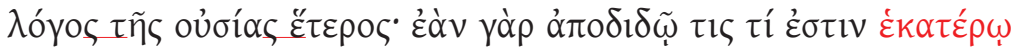

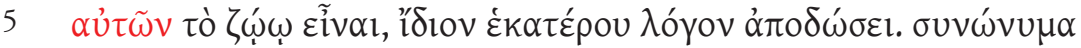

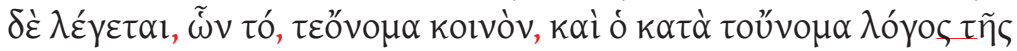

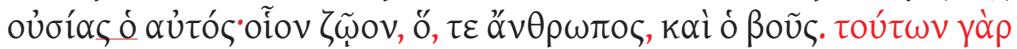

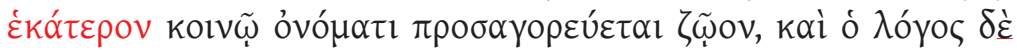

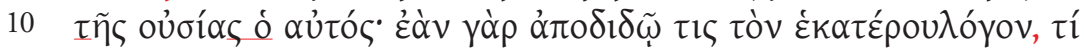

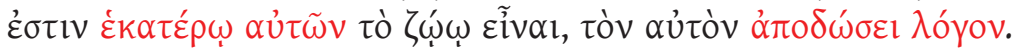

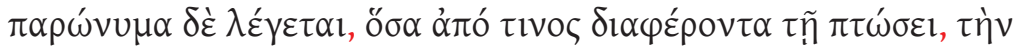

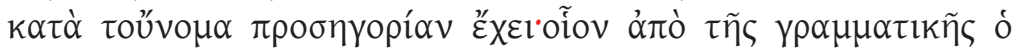

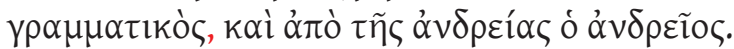

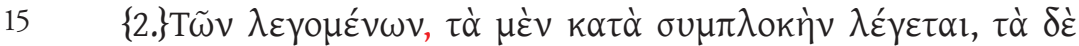

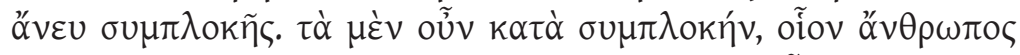

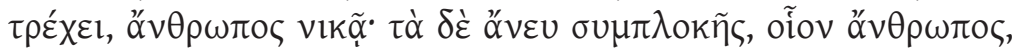
ßoũ $, \tau \rho \varepsilon ́ \chi \varepsilon l, ~ v ı \kappa \tilde{\alpha}$.

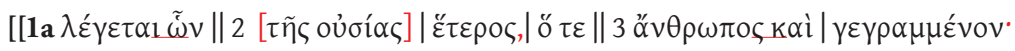

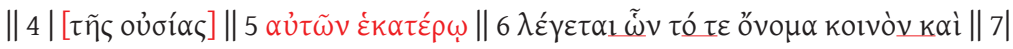

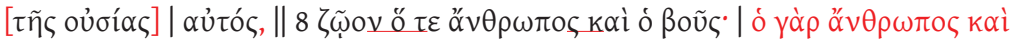

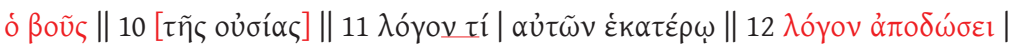

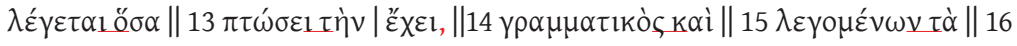

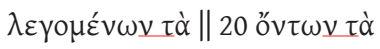




\section{CATEGORIAS ${ }^{54}$}

[AFORISMO]1. Equívocos dizem-se os que têm somente o nome comum; mas a razão desse nome diferente (1).

[EXPLICAÇÃO]1. Exemplo: Animal tanto o é o homem, como aquele nome escrito. Entretanto não tem de comum senão o nome; mas a razão desse nome é diferente para cada um deles. Porquanto se algum houver de dar a razáo de se aplicar o nome de animal a cada qual deles; para cada um há de dar uma razáo particular.

[A]2. Unívocos porém dizem-se os que não somente têm o nome comum; mas também a razão desse nome idêntica (2).

[E]2. Exemplo: Animal tanto o é o homem, como o boi: porque ambos eles se designam pelo nome comum de animal. E até mesmo a razão desse nome é idêntica para ambos. Porquanto se alguém houver de dar a razão, porque qualquer deles é animal, deve dar uma e a mesma razão.

[A]3. E cognominados dizem-se os que tendo a terminação diferente, têm contudo as atribuiçóes, que esse nome designa, idênticas (3).

[E]3. Exemplo: De Gramatica, Gramático; de Valor, Valoroso.

[A]4. Das Locuções, umas exprimem-se ligadas: outras desligadas (4).

[E]4. Umas ligadas, como: o homem corre: o homem vence. Outras desligadas, como: Homem, Boi, corre, vence.

Na seção de Aforismos o tradutor circunscreverá tudo aquilo que ele considera "elementar", e nas Explicaçôes tudo aquilo que "não acrescenta nada ao que fica dito", servindo apenas para clarificar o que foi dito:

54 No quadro acima o texto grego das Categorias é o da edição de Casaubon, com o grifo em vermelho, indicando as alteraçóes sofridas no texto em ediçóes contemporâneas, aqui colecionadas, no aparato crítico com a edição de Richard Bodéüs, publicada em 2002, por Les Belles Lettres. 
"Consiste pois esta unicamente em separar, à maneira de Notas, toda aquela parte do original, que não acrescenta nada ao que fica dito, e só serve a exemplificar, ou aclarar por qualquer outro modo, o que precede: sem que este novo arranjo violente a ligação de uma e outra coisa: nem eu tenha para isso omitido, acrescentado, ou substituído palavra alguma, do Original, pois antes as conservei na ordem da sintaxe, que cada uma delas ali ocupa. Duas são as vantagens, que me parecia, seguirem-se desta disposição: primeira, tornarem-se mais sensíveis e perceptíveis as doutrinas do Autor: Segunda, convidar mais a lerem-se, e facilitar o consultarem-se Obras, que se por algum tempo jazeram $(a)^{55}$ em uma espécie de injusto esquecimento: e por não lidas experimentaram um tanto mais injusto desprezo; isso derivou em grande parte do fastio que causava aquela multiplicidade de explicaçôes, que interrompem a dado passo o fio das idéias." ${ }^{56}$

As justificativas explicitando o plano de tradução utilizado aparecem também na "Advertência", que, tal como nas Preleçôes Filosóficas, antecede a tradução, de modo a dimensionar o contexto do trabalho filosófico.

E, se na primeira parte da "Advertência" podemos inferir um primeiro preceito do tradutor: a fidelidade ao texto original, sem acréscimos ou substituição de qualquer palavra, que devem ser conservadas em sua sintaxe original; na segunda, o valor 'formador' e 'educativo' da tradução é compreendido em dois aspectos, o da hermenêutica da obra filosófica, na medida em que as ideias de um autor podem ser mais facilmente lidas e apreendidas, e preservadas de um "injusto esquecimento". Logo, também não será difícil reencontrarmos aqui, mais uma vez explicitada, a coalescência entre a "arte de pensar" e a "arte de falar", posto que "a ordem da escrita, em nada altera, nem a ordem das idéias, nem a da leitura".

$\mathrm{Na}$ segunda parte da "Advertência" veremos que a escolha das Categorias não é apenas uma escolha filosófica, mas, também, uma escolha que, ao se demarcar como 'formadora', aponta para a tese de que a construção de

$55 \mathrm{O}$ (a) refere-se à nota acrescentada por Pinheiro Ferreira justificando o uso do pretérito do verbo jazer: "(a) Seja-me desculpado o uso deste pretérito do verbo jazer. Eu sei que os nossos bons Escritores ou se serviram de jouveram, ou o evitaram. Mas o uso geral na conversação e trato da Corte, não menos do que a analogia, são bastante autoridade em meu favor." Cf. Cat, f.4, 1814 .

56 Ferreira 1814: f.4. Grifos nossos. 
uma nação, ou melhor, a "fundação" da nação deve pautar-se também no domínio da "arte de pensar" e da "arte de falar":

\begin{abstract}
"Ninguém, que com reflexão tenha lido os Filósofos dos antigos e modernos tempos, poderá negar a Aristóteles a primazia sobre todos eles. E portanto as suas Obras deviam ser naturalmente as primeiras, que figurassem nesta como Biblioteca de Filosofia, que tenho empreendido. [...]

Quisera eu que o texto grego aparecesse em frente desta tradução: tanto para excitar a Mocidade ao estudo da Língua Grega, que no meu conceito constitui o mais glorioso monumento da perfeiçáo do Espírito humano; como também porque devendo esta tradução abundar em defeitos inevitáveis pelo pouco tempo em que sou obrigado a fazê-la e publicá-la; conviria muito, que a facilidade de a cotejarem com o texto oferecesse aos inteligentes o meio de corrigirem as faltas, que nela não pode deixar de haver em grande número, e muitas vezes de grande nota.

Por maior porém que fosse este meu desejo, não me foi possível satisfazê-lo; já porque neste nascente Estado faltam os meios para se fazer uma correta edição de um texto grego; logo que exceda a certos e muitos acanhados limites: já porque a carestia excessiva dos materiais e da mão-de-obra tornaria inútil para a maior parte das pessoas, a cujo uso este meu trabalho é dirigido, uma obra, que tendo unicamente em vista a instrução da Mocidade, deve estar ao alcance até daqueles mesmos que não gozam de avultados bens da fortuna." ${ }^{7}$
\end{abstract}

Nesse sentido, seria oportuno lembrar que as Categorias, sobre a qual pesam muitas dúvidas sobre sua autencidade, foi tida pela tradiçáo neoplatônica como um texto fundamental no processo de iniciação à filosofia e, que, juntamente com o Sobre a Interpretaçâo e os Primeiros Analiticos, formava uma tríade - com uma lógica dos termos, uma lógica das proposiçóes e uma lógica dos raciocínios - introdutória à filosofia, que Pinheiro Ferreira parece ter em conta em seu projeto de preleçôes filosóficas. ${ }^{58} \mathrm{E}$ às objeçóes feitas por Hipólito da Costa, no Correio Braziliense, que envolviam: [i] o caráter

57 Ferreira 1814: f. 1-5. Grifos nossos.

58 Sobre a questão da autencidade das Categorias, veja-se, por exemplo, Brunschwig, J. Les Catégories. DPhA, I, 1994: 109-124; Bodéüs 1995: 141-154; Dumoulin 1980: 23-32; Ross 1939: 427-433, e Rutten 1985: 315-336. 
'elementar' das Preleçóes Filosóficas - não um curso elementar de filosofia, como havia suposto o correspondente do Correio Braziliense -, tanto no que diz respeito à "instrução da mocidade" (náo para toda a mocidade, mas para aquela que já tenha um curso de estudos que lhe dê os princípios e o entendimento da linguagem das ciências), quanto ao fato delas trazerem à tona "os princípios elementares da Filosofia"; [ii] a "abundância de definições", que, ao contrário do que pensa Hipólito da Costa, constituem-se em um modo de apreensão da "verdade" que, como parte da "Arte de ensinar", compôe-se em "um tesouro", cujas chaves "são as definiçôes"; [iii] a definição da palavra 'definiçãa', e, [iv] a crítica feita aos comentários ao texto das Categorias e ao fato de o autor ignorar que elas foram falsamente atribuídas a Aristóteles:

[...] "as observaçôes que da IX Preleção por diante se encontram sobre as Obras d'Aristóteles com qualquer dos inumeráveis Comentadores daquele Filósofo; e mostre de qual deles extraídas. E já que falamos d'Aristóteles, de quem o mesmo Crítico diz que eu deveria saber que as Categorias lhe foram falsamente atribuídas; respondo: que sendo para o meu intento questáo muito ociosa, como se chamava o Autor daquela Obra, pois que isso nada tira nem acrescenta ao seu merecimento; me não devo demorar em mostrar que ela é com efeito de Aristóteles; e limito-me a remeter o nosso Crítico para a Prefação que o célebre Buhle fez preceder às mesmas Categorias na edição que deu das Obras d'Aristóteles em Duas Pontes no ano 1791, e seguintes."59,

Pinheiro Ferreira irá respondê-las na $18^{a}$ Preleção e no Suplemento ao Índice das vinte e duas primeiras preleções.

Portanto, a opção pela tradução do texto grego, o lamento pela impossibilidade de uma edição bilingue, grego-português, cumpre, também, conforme sublinha nosso autor, a função 'formadora' - tanto no que diz respeito ao exercício da filosofia, quanto ao da cidadania -, que pretende, pela "instruçáo da mocidade", garantir, como já sublinhara em O Patriota, a "contemporaneidade dos séculos". ${ }^{60}$ Sob essa ótica, o filósofo e o tradutor não estão dissociados, e a possibilidade de traduzir parece ser uma exigên-

59 Cf. Preleçôes Filosóficas, \$583-588, e Suplemento 1813: 99-100.

60 Veja-se o item 1.1, p. 7-8; 16-21. Para a importância filosófica do conhecimento das línguas, cf. Preleçöes Filosóficas, \$949-952. 
cia, uma condição natural, da reflexão filosófica, sobretudo em um "nascente Estado" como o Brasil, nas primeiras décadas do século XIX.

Assim, o processo em que as naçóes "se civilizam", ${ }^{61}$ a "construção do Bom Gosto" "62, supóe, para o nosso filósofo, não somente a coalescência entre a "Arte de Pensar" e a "Arte de Falar", mas, também, a 'Arte de Traduzir' como substrato da comunidade política, da conformação do Estado no alicerce secular da contemporaneidade das ideias, que poderá ser confirmada em toda a reflexão silvestriana acerca da monarquia como forma constitucional, esboçada nas Memórias politicas sobre os abusos gerais e os modos de os reformar e prevenir a revolução no Brasil, redigidas por ordem do Príncipe Regente, em 1814/1815, nas Cartas sobre a Revoluçáo do Brasil, e, posteriormente, nas Observaçôes sobre a Constituição do Império do Brasil e sobre a Carta Constitucional do Reino de Portugal, e no Manual do Cidadão em um Governo Representativo, publicado, em aparente forma 'dialogal', pois constituído de perguntas e respostas, sem, entretanto, a determinação de personagens, em 1834.

Ao revigorar as Categorias aristotélicas em "Aforismos" e "Explicaçôes", Pinheiro Ferreira estava, certamente, redefinindo no "Novo Mundo" a antiga concepção grega de 'politeía' e subscrevendo o estatuto da vida política - dos direitos e deveres dos cidadáos e do Estado - na "contemporaneidade dos séculos", prescrita em "O Patriota" e revisitada no aparato filosófico das Preleçôes, e tão bem explicitada na paráfrase do primeiro Aforismo do Corpus

61 Que o Brasil estivesse no horizonte silvestriano, o parecer escrito por ele, em março de 1822, sobre a situação do Brasil, parece ratificar: "O Brasil desde seu descobrimento tem sido sempre governado colonialmente, quer dizer, por medidas e providências que os governadores de cada capitania julgavam ser ditadas pelas circunstâncias. Esta é a única forma de governo praticável em uma sociedade nascente. Mas S. M., depois de ter estado alguns anos no Brasil, convenceu-se de que as principais povoaçóes dele estavam já chegadas àquele grau de civilização em que as sociedades deixam de ser governadas por ditadores para o serem por magistrados sujeitos a uma marcha regular e conforme a um sistema de leis uniformes em toda a extensão da monarquia. Foi nesta mente pois que S. M. declarou o Brasil elevado à categoria de reino." (Ferreira, 1822, f.2, Manuscrito I - 31, 22, 009, FBN).

62 A importância 'filosófica das línguas', a função gnosiológica da 'gramática filosófica' expostas em $O$ Patriota e fundamentadas nos comentários ao texto de Aristóteles nas Preleçôes Filosóficas, no $\$ 941$, remete específicamente para a "formação do Gosto”: "E se é indispensável a todo o homem que quer formar o Gosto sobre os diferentes gêneros de Poesia ler o Ariosto, o Tasso, Corneille, Racine, Lafontaine, Shakespeare, Milton, Klopstock, etc, nos seus originais; como poderá suprir o que só em Homero, em Sófocles, em Demóstenes, em Horácio, em Terêncio, em Cícero, se pode encontrar, nem se pode traduzir em nenhuma outra Língua?” 
Hippocraticum feita por Pedro Nava, em 1948, citada na epígrafe deste texto: se "os fatos são passageiros", se "as datas incertas" e se "os homens são mortais, - só as ideias sáo permanentes e eternas as categorias por que elas se exprimem." 
Politeía Tropical: a recepção dos clássicos, a tradição política no Brasil do século XIX e a tradução das Categorias aristotélicas por Silvestre Pinheiro Ferreira

\section{Referências Bibliográficas}

\section{Obras de Silvestre Pinheiro Ferreira}

\section{Manuscritos}

Ferreira, S. P. (1814), Proposta sobre o regresso da corte para Portugal e providências convenientes para prevenir a revolução, e tomar a iniciativa na reforma politica, 22 de abril. 3f. (FBN, Seção de Manuscritos, I-31,21,010.)

Ferreira, S. P. (1822), Memórias e cartas biográficas versando sobre os fatos políticos sobrevindos no Rio de Janeiro à revolução constitucionalista do Porto e Lisboa, desde suas repercussóes e consequentes sublevaçôes de fevereiro e abril de 1821 até o regresso de D. João VI com a corte para Portugal. Seção de Manuscritos da FBN, I-31, 21, 009.

Ferreira, S. P. (1821), Carta de Silvestre Pinheiro Ferreira escrita a bordo da nau D. João a 26 de maio de 1821, dirigida ao rei D. João VI, pedindo instruçōes para organizar a casa e serviço de El-rei em Lisboa. Seção de Manuscritos, FBN, II, 30, 34,9-No 1..

\subsection{Impressos}

Ferreira, S. P. (1813), Preleçōes Filosóficas. Rio de Janeiro: Impressão Régia.

Ferreira, S. P. (1970), Preleçóes Filosóficas. Introdução de Antonio Paim. 2 ed. São Paulo: Edusp, Editorial Grijalbo.

Ferreira, S. P. (1996), Preleções Filosóficas. Introdução de José Esteves Pereira. Lisboa: Imprensa Nacional.

Ferreira, S. P. (1814), Aristóteles. Categorias. Tradução e notas por Silvestre Pinheiro Ferreira. Rio de Janeiro: Impressão Régia.

Ferreira, S. P. (1884), "Memórias políticas sobre os abusos gerais e modos de os reformar e prevenir a Revolução Popular, redigidas por ordem do Príncipe Regente - 1814/1815”, Instituto Histórico e Geográfico Brasileiro 47: 1-13. [a1814]

Ferreira, S. P. (1826), Essai sur la psychologie, comprenant la théorie du raisonnement et du langage, l'ontologie, l'esthétique et la dicósyne. Paris: Rey et Gravier; J. P. Allaud.

Ferreira, S. P. (1831), Observaçóes sobre a carta constitucional do Reino de Portugal e a constituição do Império do Brasil. Paris: Of. Typ. De Casimir.

Ferreira, S. P. (1834), Manual do cidadão em um Governo Representativo, ou princípios de direito constitucional administrativo e das gentes. Paris: Rey e Gravier. [3v.] 
Ferreira, S. P. (1835), Observaçôes sobre a constituiçāo do Império do Brazil e sobre a Carta Constitucional do Reino de Portugal. $2^{\text {a }}$. ed. aumentada com as observaçôes do mesmo autor sobre a lei das reformas do Império do Brazil. Paris: Rey e Gravier; J. P. Aillaud.

Ferreira, S. P. (1837), Breves observaçōes sobre a constituição política da monarquia portuguesa: decretada pelas Cortes Gerais extraordinárias e constituintes ... . Paris: Rey et Gravier.

Ferreira, S. P. (1839), Noçôes Elementares de Philosophia e suas aplicaçôes às sciências morais e politicas. Paris: Rey et Gravier.

Ferreira, S. P. (1841), Precis d’un cours de philosophie élémentaire: ontologie, psychologie, idéologie. Paris: Eduard Garnot.

Ferreira, S. P. (1843), "Divisão do império do Brasil em cinco monarquias confederadas - Sr. D. Pedro 2o chefe da Confederação”, Diário do Rio de Janeiro, 22 nov.: 1.

Ferreira, S. P. (1887), "Cartas sobre a revolução no Brasil, editadas por F. Ramiz Galvão”, Anais da Biblioteca Biblioteca Nacional. [v. 2 e 3]

Ferreira, S. P. (1888), "Cartas sobre a revolução do Brasil", Instituto Histórico e Geográfico Brasileiro 51. 1: 239-377.

Ferreira, S. P. (1960), "Silvestre Pinheiro Ferreira: Escritos Filosóficos”, Revista da Universidade de Coimbra 19: 29-319.

Ferreira, S.P. (1976), Ideias Políticas. Rio de Janeiro: PUC-Rio; Editora Documentário. [Coletânea de textos].

\subsection{Outras fontes consultadas}

Bacelar, B. L. M. (1783), Gramática filosófica e ortográfica racional da língua portuguesa. Lisboa: Na Officina de Simão Thaddêo Ferreira.

Barbosa, J. S. (1822), Gramática filosófica da lingua portuguesa, ou princípios da Gramática geral aplicados à nossa linguagem. Lisboa: Tipografia da Academia das Ciências.

Couto e Melo, J. C. (1818), Gramática filosófica da linguagem portuguesa. Lisboa: Impressão Régia.

Centro de Documentação do Pensamento Brasileiro (1982), Silvestre Pinheiro Ferreira (17691846): Bibliografia e estudos. Salvador: CDPB.

Garat, D.-J. (1783), "Lettres sur Bayonne et les Basques”, Mercure de France 8: 63-73.

Marrocos, L. J. dos S. (1934), "Cartas de Luiz Joaquim dos Santos Marrocos, escritas à sua família no Rio de Janeiro, de 1811 a 1821”, in Anais da Biblioteca Nacional do Rio de Janeiro. Rio de Janeiro, Serviço Gráfico do Ministério da Educação.

(1849), Novo Catálogo das Obras do Publicista Português Silvestre Pinheiro Ferreira que existem à venda em Lisboa .... Lisboa: Typ. J. B. Morando, 24 p.

(1813-1814) O Patriota, Jornal Literário, Político, Mercantil. Rio de Janeiro: Impressão Régia. 
Politeía Tropical: a recepção dos clássicos, a tradição política no Brasil do século XIX e a tradução das Categorias aristotélicas por Silvestre Pinheiro Ferreira

Silva, I. F. da (1862), Silvestre Pinheiro Ferreira, in Dicionário Bibliográfico Português. Lisboa, t. 7: 259-273.

Verney, L. A. (1746), Verdadeiro Método de Estudar para ser útil à República e à Igreja: proporcionado ao estilo e necessidade de Portugal exposto em várias cartas escritas pelo R.P. ${ }^{* * * B a r b a d i n h o ~ d a ~ C o n g r e g a c ̧ a ̃ o ~ d e ~ I t a ́ l i a ~ a o ~}{ }^{* * *}$ R. R.P. Doutor da Universidade de Coimbra. Valença: Oficina de Antonio Balle. [2 v.]

Zaidman, D. (1977-1978), “O Patriota, jornal literário, político e mercantil, 1813-1814. Índice”, in Rodrigues, J. H. (Coord.), Coleção Mattoso Maia de Instrumentos para Pesquisa em História do Brasil. Niterói: UFF.

\section{Aristóteles: Ediçôes e Comentários}

\subsection{Edições das Categorias}

Bekker, I. (1831), Aristotelis opera, ex recensione Immanuelis Bekkeri. Berlin: Academia regia Borussica. [Editio altera qvam cvravit Olof Gigon, Berlin, 1960], p. 1-15, t. 1.

Bodéüs, R. (2002), Aristote. Catégories. Texte établi et traduit par R. Bodéüs. Paris: Les Belles Lettres.

Casaubon, I. (1590), Aristotelis stagiritae philosophorvm Omnivn longe principis. Lyon: Guillelmun Laemarium.

Colli, G. (1955), Organon. Introduzione, traduzione e note di Giorgio Colli. Turin: Einaudi.

Paluello, M. (1949), Aristotelis Categoriae et liber De interpretatione, recognovit brevique adnotatione critica instruxit. Oxford: Oxford University Press. [reimp. 1949, OCT].

\subsection{Estudos e Comentários às Categorias e História do Texto.}

Bodéüs, R. (1995), "Sur l'unité stylistique du texte des Catégories d'Aristote", in Motte, A. e Denooz, J. (eds.), Aristotelica Secunda: Mélanges offerts à Cristian Rutten. Liège: C.I.P.L.: 141-154.

Dumoulin, B. (1980), “Sur l'authenticité des Catégories”, in Aubenque, P. (éd.), Concepts et catégories dans la pensée antique. Paris: Vrin: 23-32.

Düring, I. (1990), Aristóteles. Traducción y edición de Bernabé Navarro. México: UNAM.

Rutten, Chr. (1985), Stylométrie des Catégories. Aristotelica: Mélanges offers à M. De Corte. Bruxelles-Liège, Ousía: 315-336.

Schmitt, C. (1992), Aristote et la Renaissance. Traduit de l'anglais et présenté par Luce Giard. Paris: PUF. 


\section{Estudos e Comentários}

Alcides, S. (2007), "O lado B do neoclassicismo luso-brasileiro: patriotismo e poesia no 'poderoso império'", in Kury, L. (Org.), Iluminismo e império no Brasil: O Patriota (1813-1814). Rio de Janeiro: Fiocruz: 103-140.

Bordes, J. (1982), Politeía dans la pensée grecque jusqu’à Aristote. Paris: Les Belles Lettres.

Candido, A. (1976), Literatura e sociedade: estudos de teoria e história literária. 5ª . ed. revista. São Paulo: Editora Nacional.

Canfora, L. (2002), Convertire Casaubon. Milano: Adelphi.

Canfora, L., Corcella, A. (1992), "La letteratura política e la sttoriografia”, in La produzione e la circolazione del testo. Volume 1: la pólis. Roma: 433-471.

Carvalho, L. R. (1978), As reformas pombalinas da Instrução Pública. São Paulo: Edusp.

Cataldi, S. (2004), Poleis e Politeiai: experienze politiche, tradizioni letterarie, progetti constituzionale. Atti del Convegno Internazionale di Storia Greca. Alessandria: Edizioni dell'Orso.

Costa, J. C. (1956), Contribuição à história das idéias no Brasil. Rio de Janeiro: José Olympio.

Couto, M. A. (2004), "Gramática e a teorização linguística em Portugal: a Gramática Filosófica de João Soares Barbosa”, Revista Galega de Filoloxía 5: 11-31

Coxito, A. (2006), Estudos sobre a filosofia em Portugal na época do Iluminismo. Lisboa: Imprensa Nacional-Casa da Moeda.

Cruz, I. (2001), "Silvestre Pinheiro Ferreira: o viajante sombra", Atalaial Intermundos. Revista do Centro Interdisciplinar de Ciência, Tecnologia e Sociedade da Universidade de Lisboa 8/9: 308-330, 2001. (disponível também em http://www.triplov.com)

Ehrenberg, V. (1980), Lo stato dei greci. Traduzione de Ervino Pocar. Firenze: La Nuova Itália.

Ferreira, T. M. T. B. da C. (2007), "Redatores, livros e leitores em O Patriota", in Kury, L. (Org.), Iluminismo e império no Brasil: O Patriota (1813-1814). Rio de Janeiro: Fiocruz: 41-66.

Gonçalves, M. F. (2006), "Iluminismo e pensamento linguístico em Portugal: o exemplo das gramáticas filosóficas", Actas do VI Congrès de Linguistica General. Barcelona, 18-21 de abril de Universitat de Barcelona. [Gonçalves, Maria Filomenta. Maria https://www. academia.edu/6410929/Iluminismo_e_pensamento_linguistico_em_Portugal_o exemplo_das_gramaticas_filosoficas]

Guimarães, M. L. S. (2007), “As luzes para o Império: história e progresso” in Kury, L. (Org.), Iluminismo e império no Brasil: O Patriota (1813-1814). Rio de Janeiro: Fiocruz: 67-102.

Houaiss, A. (2001), Dicionário Houaiss da língua portuguesa. Rio de Janeiro: Objetiva. 
Politeía Tropical: a recepção dos clássicos, a tradição política no Brasil do século XIX e a tradução das Categorias aristotélicas por Silvestre Pinheiro Ferreira

Kristeller, P. (1995), Tradição clássica e pensamento do Renascimento. Tradução de Artur Mourão. Lisboa: Edições 70.

Kury, L. (2007), “Descrever a patria, difundir o saber”, in Kury, L. (Org.), Iluminismo e império no Brasil: O Patriota (1813-1814). Rio de Janeiro: Fiocruz: 141-178.

Lidell, H. J., Scott, R. e J. (1983), A Greek-English Lexicon. Oxford: Oxford University Press.

Lima, M. de. O. (2006), D.João VI no Brasil. 4.ed. Rio de Janeiro: Topbooks.-Lyra, M. de L. V. (1994), A utopia do poderoso império. Portugal e Brasil: bastidores da política, 17981822. Rio de Janeiro: Sette Letras.

Manchester, A. K. (1970), "A transferência da Corte Portuguesa para o Rio de Janeiro", in Keith, H., Edwards, S. F. (eds.), Conflito e continuidade na sociedade brasileira. Tradução de Laurêncio de Melo. Rio de Janeiro: Civilização Brasileira: 177-217.

Manville, P. B. (1990), The origins of citizenship in ancient Athens. Princeton: Princeton University Press.

Moraes Augusto, M. G. de. (2010), "A tradição da retórica clássica no Brasil: entre a filosofia e a poesia”, in Assunção, T. R., Flores-Jr, O., Santos, M. M. (eds.), Ensaios de retórica antiga. Belo Horizonte: Tessitura: 313-350.

Moraes Augusto, M. G. de (2012/2013), “Politeía e utopia: o caso platônico”, Kléos, Pragma/ UFRJ 16-17: 128-135.

Moraes, R. B. de. (1969), Bibliografia brasileira do periodo colonial: Catálogo comentado das obras dos autores nascidos no Brasil e publicadas antes de 1808. São Paulo: Instituto de Estudos Brasileiros da Universidade de São Paulo.

Moraes, R. B. de (2006), Livros e bibliotecas no Brasil colonial. 2.ed. Brasília: Briquet de Lemos Livros.

Morel, M. (2007), "Pátrias polissêmicas: República das Letras e imprensa na crise do império português na América, in Kury, L. (Org.), Iluminismo e império no Brasil: O Patriota (1813-1814). Rio de Janeiro: Fiocruz: 15-40.

Nascentes, A. (1967), Dicionário da Lingua Portuguesa. Rio de Janeiro: Academia Brasileira de Letras, Imprensa Nacional. $4 \mathrm{v}$.

Paim, A. (1974), História das idéias filosóficas no Brasil. 2 ed. São Paulo: Grijalbo, Edusp.

Paim, A. (1974), "Introdução", in Ferreira, Silvestre Pinheiro. Preleçōes Filosóficas. 2 ed. São Paulo: Edusp, Editorial Grijalbo: 7-12.

Pattison, M. (1892), Isaac Casaubon - 1559-1614. Oxford: Clarendon Press.

Praça, J. J. Lopes (1974), História da filosofia em Portugal. Lisboa: Guimarães.

Rizzini, C. de A. (1988), O livro, o jornal e a tipografia no Brasil: (1500-1822). São Paulo: Imprensa Oficial do Estado de São Paulo, Imesp. (Ed. Fac-similar). 
Saraiva, A. J. (1996), Por uma história da cultura em Portugal: Renascimento e Contra Reforma. 2.ed. Lisboa: Gradiva. v. 2.

Sérgio, A. (1934), Ensaios. Lisboa: Seara Nova.

Silva, M. B. N. (1975), Silvestre Pinheiro Ferreira: ideologia e teoria. Lisboa: Sá da Costa.

Silva, M. B. N. (1978), Cultura e sociedade no Rio de Janeiro:1808-1821. 2.ed. São Paulo: Ed. Nacional. (Brasiliana, v. 363)

Silva, M. B. N. (2005), Ser nobre na Colônia. São Paulo: Unesp.

Sucupira, N. (1976), "O Seminário de Olinda e outros seminários”, in Diegues Júnior, M. (Org.). História da Cultura Brasileira. Rio de Janeiro: MEC/FENAME/CFC: 356373.

\section{Nota final}

Esta pesquisa vem sendo desenvolvida com o apoio do PNAP/2013, da Fundação Biblioteca Nacional do Rio de Janeiro, a quem agradecemos. Gostaríamos, também, de sublinhar agradecimentos especiais às bibliotecárias da FBN, Vera Lúcia Faillace, chefe da Seção de Manuscritos, à Profa. Ana Virgínia Pinheiro, chefe da Seção de Obras Raras, pela atenção e pela generosidade com que sempre me têm auxiliado nas muitas dificuldades encontradas, como sabemos, no dia-a-dia de uma pesquisa, e ao mestrando Luan Roborêdo Lemos, pelas afinidades na leitura das Categorias. 


\title{
Musas errantes: \\ Tesouros da Antiguidade Clássica no labirinto da Biblioteca Nacional Brasileira
}

(Errant Muses: Treasures from Classical Antiquity in the labyrinth of the Brazilian National Library)

\author{
Ana Virginia Pinheiro \\ Fundação Biblioteca Nacional (Brasil) \\ Universidade Federal do Estado do Rio de Janeiro \\ (anavirginiapinheiro@oi.com.br)
}


Página deixada propositadamente em branco 
Resumo - Aborda as práticas de catalogação dos textos impressos artesanalmente em grego e em outras línguas consideradas "exóticas", do acervo da Biblioteca Nacional Brasileira, e suas condições de localização e acesso, e propõe solução para o resgate dessa memória, ainda por desvelar.

PALAVRAS-CHAVE - Impressos em grego. Impressos em línguas exóticas.

Abstract - This article addresses the cataloging practices of handmade printed texts in Greek and other languages considered "exotic", belonging to the National Library of Brazil, as well as its location and access conditions, and proposes the solution to recover this memory, even for unveiling.

KeY-words - Printed Manuscripts in Greek. Printed Manuscripts in Exotic Languages.

Categorias são exclusivas, a leitura não o é-ou não deveria ser. [...] cada biblioteca tiraniza o ato de ler e força o leitor - o leitor curioso, o leitor alerta - a resgatar o livro da categoria a que foi condenado. Alberto Manguel ${ }^{1}$

O título deste ensaio sobre a recepção dos clássicos, especificamente, sobre o acesso a textos impressos artesanalmente em grego, disponíveis no acervo da Biblioteca Nacional do Brasil, foi inspirado em parte do título da edição latina dos Emblemata de Albertinus², que citou as nove musas, consagradas na mitologia grega como filhas de Zeus (rei dos Olímpicos) e Mnemósine (deusa da Memória), para explicar como era a ordem dos livros na Biblioteca de Alexandria - uma biblioteca modelar, desenvolvida em torno do Mouseion, o templo das musas, o lugar de produção e de preservação das artes e das ciências.

Se Calíope (Eloquência), Clio (História), Érato (Verso erótico), Euterpe (Poesia lírica, Música), Melpômene (Tragédia), Polímnia (Hinos Sagrados, Música cerimonial), Tália (Comédia), Terpsícore (Dança) e Urânia (Astronomia e Astrologia) eram musas capazes de inspirar a criação registrada em múltiplos suportes, os lugares de salvaguarda desses registros transformaram-se em labirintos, em bibliotecas carentes de desvelamento de tesouros que permanecem desconhecidos, em espaços que não motivam nem garantem sua própria longevidade.

\footnotetext{
Manguel 1997: 227.

2 Albertinus 1649.
} 
A pesquisa em bibliotecas sempre esteve alicerçada na organização, na concepção de catálogos funcionais, que traduzem os conteúdos das obras, das ideias, das mensagens objetivas ou subjetivas de um universo documentário específico e em desenvolvimento. No entanto, nem sempre os catálogos representam os acervos que teoricamente inventariam.

A verdade sobre a concepção de catálogos de bibliotecas é unívoca: constituem a expressão da visão do bibliotecário no momento da catalogação; isto é, o catálogo exibe a visão condicionada do bibliotecário - limitada a determinado número de pontos de acesso, comumente, para não sobrecarregar os sistemas eletrônicos delineados segundo padrão regular para bibliotecas correntes, de acervo continuamente atualizado; limitada à erudição de um catalogador que nem sempre tem domínio do conhecimento que é objeto da catalogação; limitada a procedimentos cerceadores que categorizam o autor, a obra, os assuntos em estrutura sistêmica pré-determinada por conveniências arbitrárias, de modo a configurar linguagem internacional - limitada, delimitada.

Essas limitaçôes são as principais causas das contínuas "descobertas" de cimélios em acervos que se assemelham a sítios arqueológicos, embora estejam catalogados.

A catalogação de obras impressas nas bibliotecas de todo o mundo segue padróes consagrados, que relevam o modo como o pesquisador naturalmente as procuraria.

O processo de busca em bibliotecas, mesmo com critérios eleitos naturalmente pelo pesquisador, exige o conhecimento desses padróes, que objetivam estabelecer ou manter o caráter mmemônico atribuído aos catálogos, desde sempre ${ }^{3}$. Porque, desde sempre, as bibliotecas investem em métodos e metodologias que contemplam a unificação de procedimentos, a integraçáo de sistemas de informação que atendem a valores de cada época - a biblioteca exaustiva, que reunia todos os livros; a biblioteca seletiva, de conteúdos determinados conforme a necessidade de formação de eruditos; e a biblioteca ideal, organizada para tornar acessível o conhecimento que intenta captar.

A ideia de biblioteca exaustiva está centrada na teoria da biblioteca alexandrina, identificada como biblioteca universal, numa referência à Biblioteca de Alexandria, criada no século III a. C., "com o objectivo de promover o helenismo e toda a sua cultura"4; monumentalizada pelas co-

\footnotetext{
3 Cf. IFLA 2009.

4 Dias 2011: 218
} 
leçóes que incorporou, tais como os livros que pertenceram a Aristóteles 5 , e que ficou famosa pelo número de vezes que se reconstruiu e se perdeu, depois de saques e incêndios documentados na História do Livro e das Bibliotecas ${ }^{6}$.

O conceito de biblioteca alexandrina deve remeter ao de biblioteca única, memorial, posto que universal, com todos os livros, de todos os autores, de todos os assuntos, devidamente ordenados. Evidentemente, desde a Antiguidade, esta era uma grande biblioteca em construção, porque "os livros podem ser continuamente acumulados"7. Se no passado sua existência estava circunscrita a um lugar, no futuro, só seria possível como biblioteca atomizada, em pequenos, médios e grandes segmentos, distribuídos por todo o mundo, cooperantes, com uniformidade de procedimentos e todas as versóes possíveis de textos anteriores e coetâneos, desde os manuscritos em rolos de papiro e pergaminho aos registros digitais, e que muitos acreditam traduzir-se, hoje, na Web.

No princípio, a partir do terceiro milênio a. C., a biblioteca era ordenada segundo o modelo de formaçáo de um erudito, determinado pelo Trivium - o conhecimento da Gramática, da Retórica e da Lógica; até incorporar, na Baixa Idade Média e até à Renascença, o modelo do Quadrivium - o conhecimento da Aritmética, da Geometria, da Música e da Astronomia ${ }^{8}$. A soma de todos esses conhecimentos reconhecia no erudito sólida formação em Artes ${ }^{9}$ e o habilitava ao uso de bibliotecas. Essas bibliotecas, até os séculos XVI e XVII, se construíam a partir de inventários, como a Bibliotheca Universalis de Konrad Gesner ${ }^{10}$, que em cerca de 12.000 verbetes pretendeu arrolar todos os livros impressos em grego, latim e hebraico, até então, assim como "textos manuscritos, autores sábios e autores menos sábios" como a Bibliotheca Selecta de Antonio Possevino ${ }^{12}$ que, em 1593 e em sucessivas edições, opôs-se à universalidade de Gesner e compilou um cânon

5 Báez 2006: 70.

6 Battles 2003: 28-60.

7 McNeely; Wolverton 2013: 32.

8 Pernoud 1944: 126-127.

9 Horch 1985: 26.

10 Gesner 1545.

11 Chartier 1997: 109-110.

12 Possevino 1593. 
bibliográfico prescritivo, uma lista para compor uma biblioteca ideal, com "os melhores instrumentos para propagar a doutrina cristâ"13.

Desde o princípio, o padrão de procedimentos em Biblioteconomia teve forte representação na catalogação, de tal modo que se uma obra não estava inventariada ou catalogada era porque, teoricamente, "não existia", ou estava "perdida", ou a biblioteca "não a possuía". Essas circunstâncias eram e são facilmente verificáveis porque a catalogação é uma estrutura padronizada, que determina o ponto de acesso principal e o corpo da entrada, oferecendo recursos de busca e localização de uma obra.

O ponto de acesso principal, comumente, é o nome do autor, quando houver, invertido pela última parte ou pelo nome paterno, ou arranjado conforme a língua do autor.

O corpo da entrada é dividido em áreas ou zonas que, no caso de obras impressas artesanalmente, é conforme, pelo menos, à sequência: título, autoridades, dados de ediçáo, lugar de publicação, casa publicadora, a data de publicação, a extensão (em volumes, partes, tomos, páginas), as ilustrações, as dimensóes (em formatos e centímetros), a série, e as notas, de caráter geral e local.

Um fundamento, no processo de catalogação, é o respeito à grafia das palavras, à língua do texto, ao modo como o autor estruturou o título, que deve ser transcrito exatamente como aparece na página de rosto da obra catalogada. Desse modo, "todas as bibliotecas, confortavelmente, contêm escritos e justapõem ideias que, [...] lá estão, sentadas nas pratelerias, esperando que surjam aqueles estudiosos a quem caberá cotejar suas contradiçôes latentes"14.

No entanto, as bibliotecas não cresceram com equilíbrio e sua aparente organização esconde o conflito quotidiano entre os métodos de organização consagrados e seus efeitos colaterais - aqueles procedimentos e fundamentos de catalogaçáo não se aplicariam a toda e qualquer obra do acervo, por diferentes motivos, mais ou menos nobres, dependendo da ocasião. Por exemplo, quando os bibliotecários curadores de acervos enfrentaram regimes de exceção e censura que levaram ao recolhimento, à subtração, à destruição de obras, cuja guarda poderia abreviar a vida de seu possuidor, decidiram pelo acolhimento secreto dessas obras; por isto, não foram catalogadas, mas foram mantidas nos acervos. Outro exemplo: as obras impressas em alfabetos cuja expressão gráfica não é reproduzível nos sistemas bibliográficos

13 Reyes Gómez 2010: 108.

14 McNeely, Wolverton 2013: 29. 
constituídos são tratadas como obras em línguas "exóticas", no contexto das práticas em Biblioteconomia; por isto, não são catalogadas, mas mantidas nos acervos.

Tudo isto leva a uma certeza: não há simplicidade ou ingenuidade na organização de uma biblioteca, porque toda biblioteca resume o caos do estado da arte do conhecimento, em sua época, e acumula o caos de épocas anteriores.

Esta certeza se configura, por exemplo, quando se constata que os sistemas de informação, que objetivam dispor a informação através do acesso em linha, de modo livre e, preferencialmente, irrestrito, foram construídos para acervos correntes e, potencialmente, utilizáveis.

Textos de produção tipográfica artesanal (do século XV ao XVIII), em línguas clássicas, "mortas" ou que apresentem ligaduras de letras, abreviaçôes e abreviaturas e outros sinais que caíram em "desuso", são catalogados com restriçóes, a despeito do interesse crescente de seus conteúdos por pesquisas vivas, em todo o mundo.

Os sentidos de "desuso" e "restriçáo", aqui, não se aplicam ao que é antigo ou ao que passou e deixou de ter interesse; dizem respeito ao tratamento que é dado a determinadas palavras e sinais diacríticos, na catalogação, para impedir ou reduzir a ocorrência de "ruídos" em sistemas de informação que não os relevaram. O mácron $\left(^{-}\right)$, a bráquia ( $\left.{ }^{\bullet}\right)$, o anel ( $\left.{ }^{\circ}\right)$, o espírito áspero (' ), o espírito brando (' ), o parágrafo ( $\mathrm{g}$ ), o E comercial (\&), o circunflexo, a cedilha, as aspas duplas, os colchetes, o trema, as palavras hifenizadas e outros sinais, que não foram previstos na concepção desses sistemas, são omitidos ou, se transcritos, ficam irreconhecíveis, ocasionando um registro catalográfico incompleto, imperfeito.

Nessas circunstâncias, os impressos que oferecem riqueza de sinalização, assim como as ediçóes em línguas ditas "exóticas" - como o hebraico, o copta, o grego - não constam ou não são recuperáveis nos catálogos físicos e eletrônicos de bibliotecas, que náo previram a necessidade de fontes específicas ou subestimaram essas ocorrências - e este é o caso da Biblioteca Nacional Brasileira e, certamente, de muitas outras bibliotecas do Ocidente.

Então, seria lógico deduzir que na Biblioteca Nacional Brasileira existem obras impressas em línguas "exóticas" que nunca foram catalogadas?

Sim, por exemplo (Figuras 1-3): 


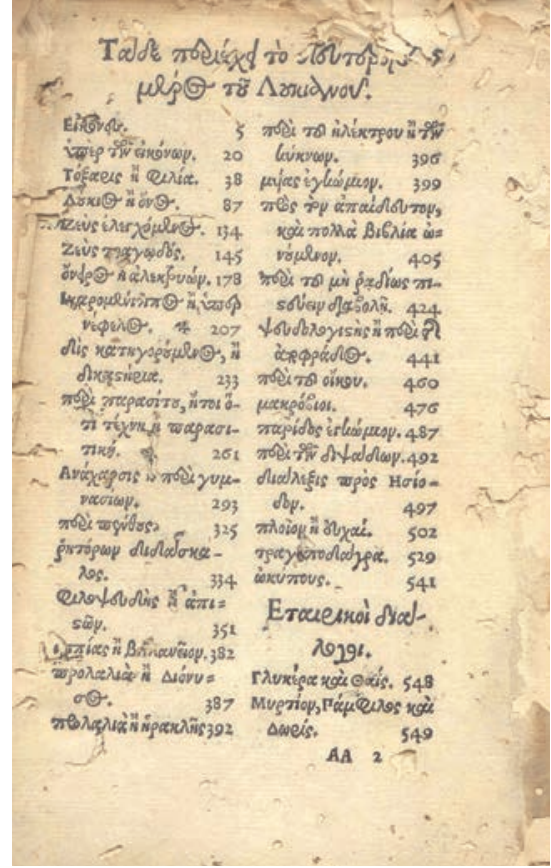

Figura 1

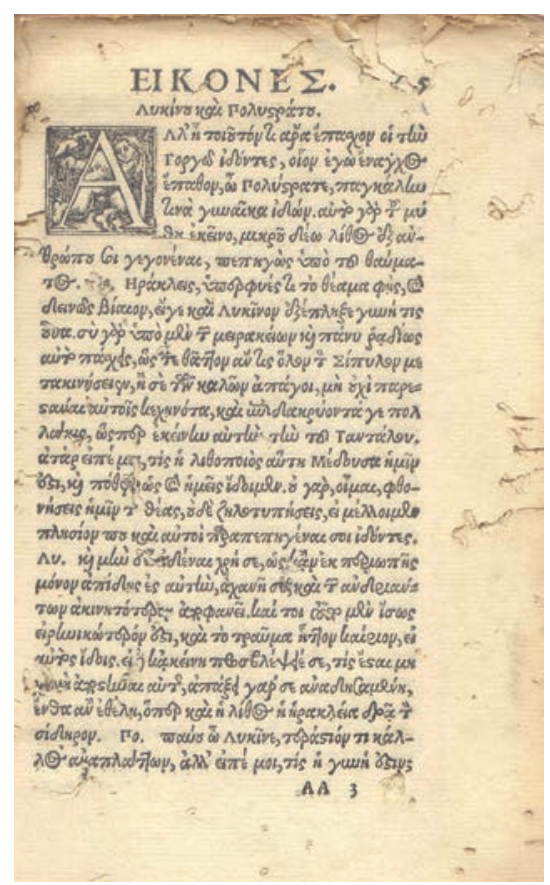

Figura 2

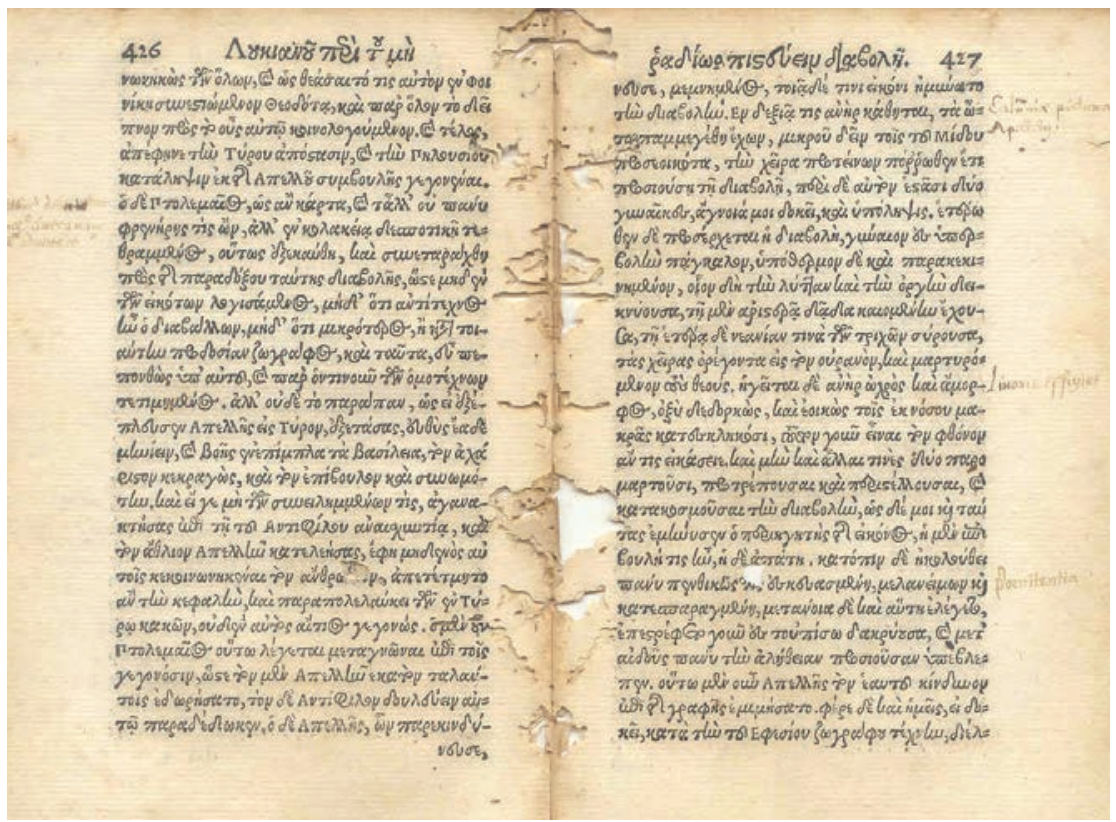

Figura 3 
Seria razoável deduzir que na Biblioteca Nacional brasileira existem obras impressas em línguas "exóticas" catalogadas de modo sumário (às vezes, incorreto), como tentativa de solução do problema de recuperação e acesso?

Sim, por exemplo (Figuras 4-5, Quadros 1-2):

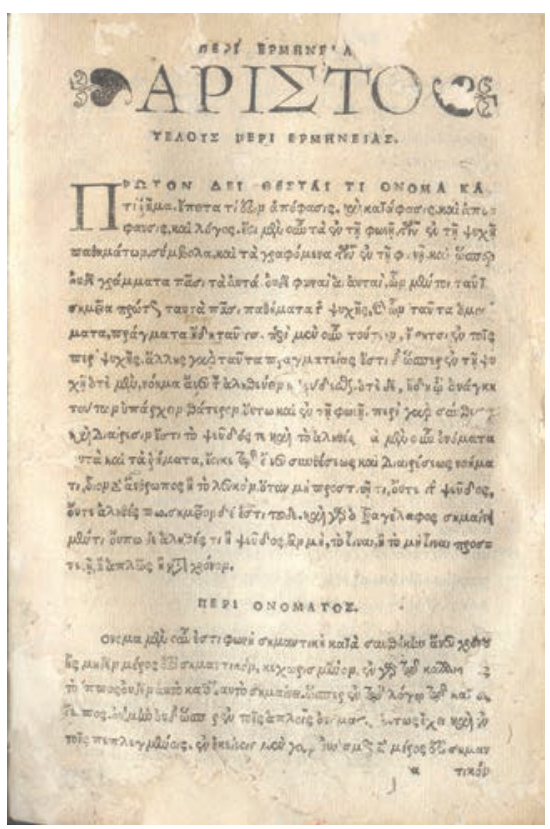

Figura 4: título de partida

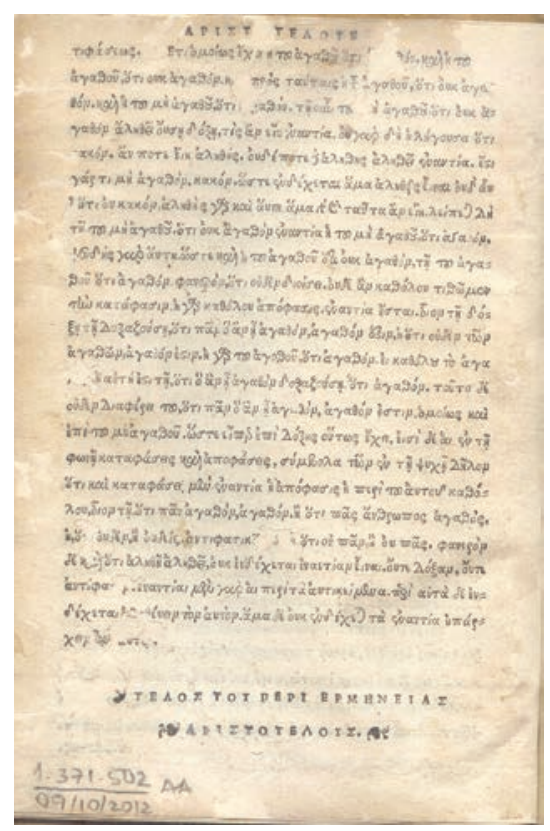

Figura 5: colofão

Quadro 1: Catalogação original

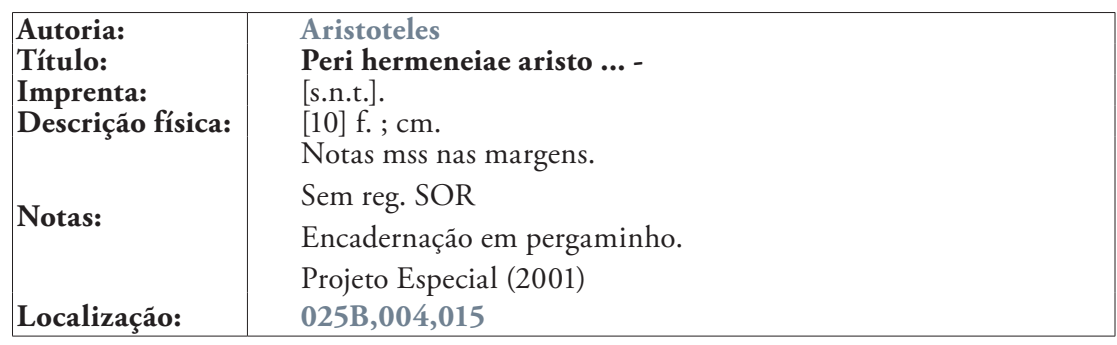


Quadro 2: Catalogação proposta

\begin{tabular}{|c|c|}
\hline Autoria: & Aristóteles \\
\hline Título uniforme & Perì Hermeneías \\
\hline Título: & Perì Hermeneías Aristo [...]. [...]. \\
\hline $\begin{array}{l}\text { Título } \\
\text { Convencionado } \\
\text { p/Arq }\end{array}$ & Organon \\
\hline Imprenta: & [S.l. : s.n., 16--?]. \\
\hline Descriçáo física: & [10] f. ; $20 \mathrm{~cm}$. \\
\hline Notas: & $\begin{array}{l}\text { Texto em grego. } \\
\text { Anotaçóes manuscritas (tinta): notas às margens e sublineares, ao } \\
\text { longo do texto. } \\
\text { Encadernaçáo: inteira, em pergaminho, com título à tinta no alto da } \\
\text { pasta anterior. }\end{array}$ \\
\hline $\begin{array}{l}\text { Notas para } \\
\text { inclusão em } \\
\text { Bibliog: }\end{array}$ & $\begin{array}{l}\text { MINIO-PALUELLO, L. Aristotelis: Categoriae et Liber De Inter- } \\
\text { pretatione. Oxford: Oxonii et Typographeo Clarendoniano, } 1974 . \\
\text { Disponível em: http://folk.uio.no/amundbjo/grar/categoriae/Minio- } \\
\text {-Paluello_print.pdf. Acesso em: } 23 \text { set. } 2013 \text {. }\end{array}$ \\
\hline $\begin{array}{l}\text { Dados } \\
\text { biográficos/ } \\
\text { históricos: }\end{array}$ & $\begin{array}{l}\text { Raridade/Importânica: "Perì Hermenías" é uma das mais antigas } \\
\text { obras de Lógica, de Aristóteles. O título significa "Sobre a Interpre- } \\
\text { tação",[...] mas é conhecida, também, pela forma latina "De Inter- } \\
\text { pretatione" desde a Renascença (BOETHIU'S translation of the Pe- } \\
\text { rihermenias. Washington, DC: The Catholic University of America, } \\
1 \text { ago. 2013. Disponível em: <http://www.logicmuseum.com/oppo- } \\
\text { sition/perihermaneias.htm>. Acesso em: } 23 \text { set. 2013; KNEALE, } \\
\text { W.; KNEALE, M. The Development of Logic. Oxford, 1971). }\end{array}$ \\
\hline Localizaçáo: & 025B,004,015 [MFN 24361] \\
\hline Microfilme: & OR-00652 (06). \\
\hline URL: & $\begin{array}{l}\text { http://objdigital.bn.br/objdigital2/acervo_digital/div_obrasraras/ } \\
\text { or1371502/or1371502.pdf }\end{array}$ \\
\hline No. Registro: & 1.371 .502 AA $09 / 10 / 2012$ \\
\hline Assunto tópico: & $\begin{array}{l}\text { Verdade (Aristóteles) } \\
\text { Organon (Aristóteles) }\end{array}$ \\
\hline
\end{tabular}

Seria possível conjecturar que na Biblioteca Nacional Brasileira existem obras impressas, com anotaçôes manuscritas, de época, em línguas "exóticas", e que náo foram explicitamente apontadas e descritas nas catalogaçóes, embora pudessem fomentar pesquisas de modo extraordinário?

Sim, por exemplo (Figuras 6-7): 


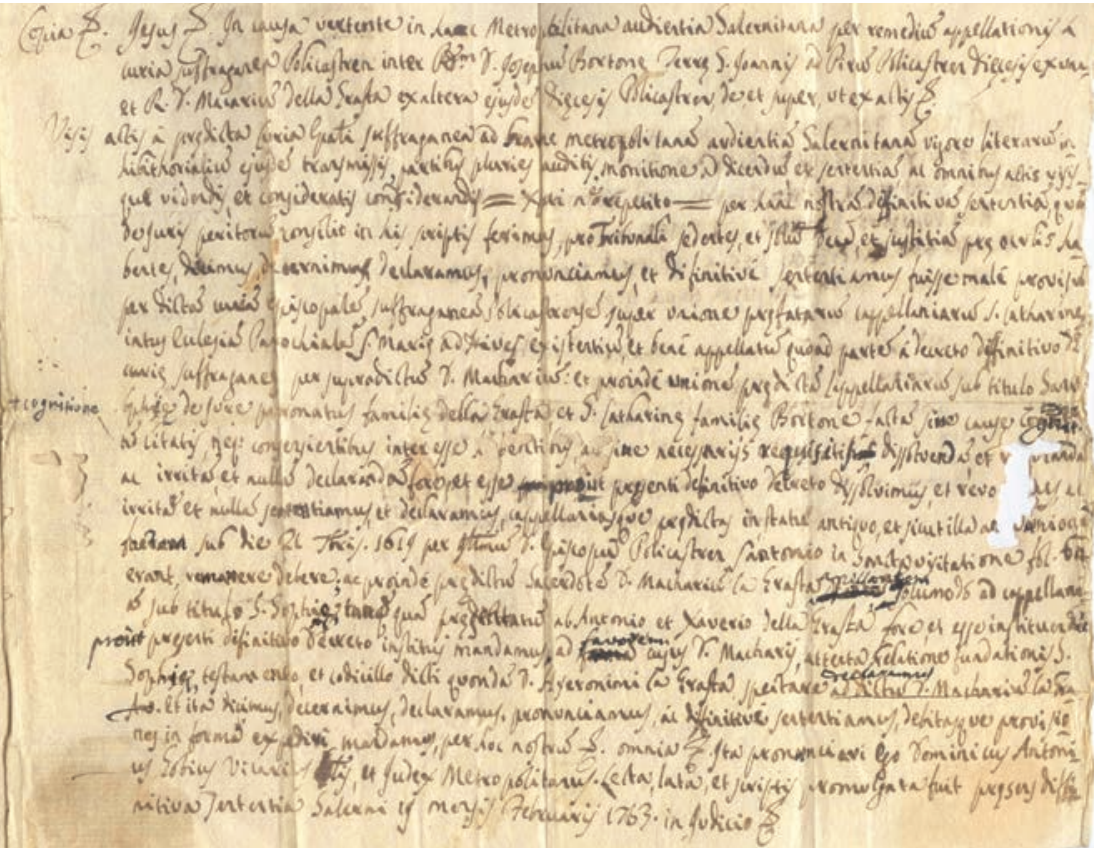

Figura 6: reto de folha inserida no Lexicon graeco-latinvm, de Joannes Scapula, 1623 (BNBr/

OR097,002BIS,001).

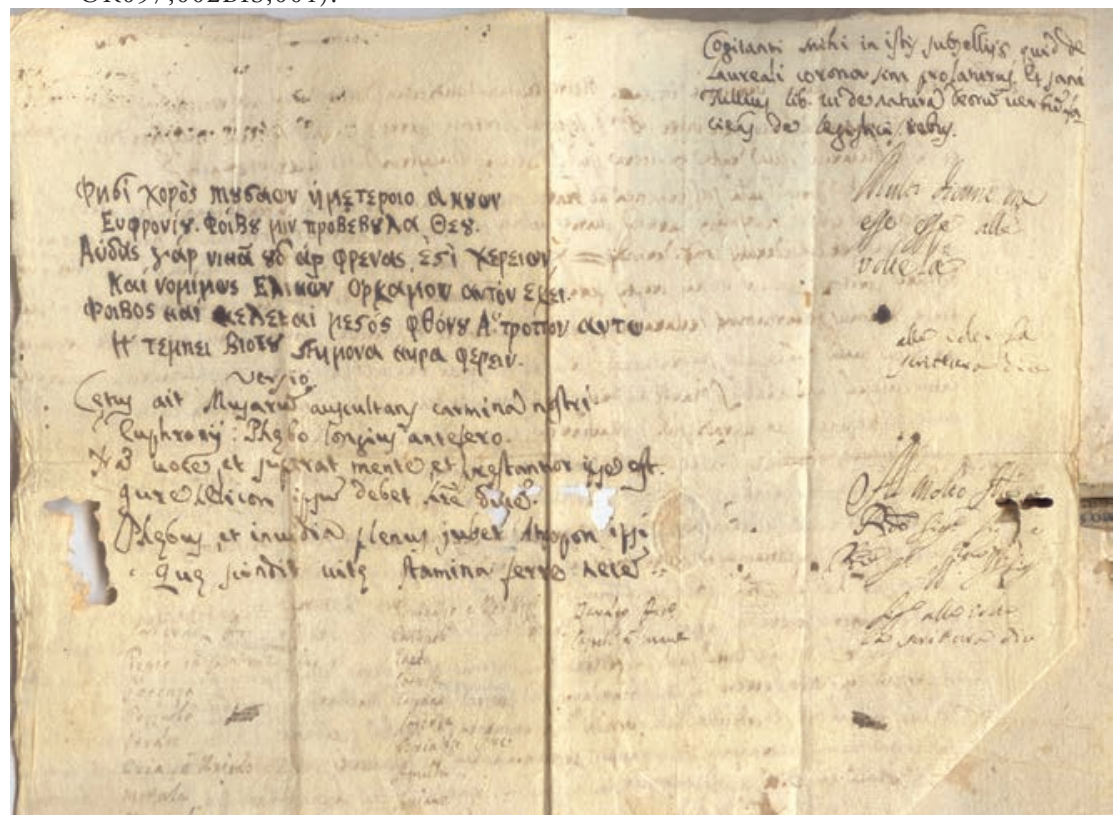

Figura 7: verso de folha inserida no Lexicon graeco-latinvm, de Joannes Scapula, 1623 (BNBr/ OR097,002BIS,001). 
Então, como solucionar essa situação de evidente desconforto para o pesquisador que, desconhecendo as intempéries do processo de catalogação de obras em línguas "exóticas", fica cada vez mais dependente de bibliotecários disponíveis e cônscios de seus deveres quanto ao oferecimento e ao acesso à informação?

Como solucionar essa situação de evidente desconforto para o bibliotecário que, diante das limitaçóes impostas pelos recursos tecnológicos da biblioteca, fica cada vez mais dependente de pesquisadores disponíveis e motivados a oferecer seu conhecimento científico para favorecer à organização da biblioteca?

Qual a prerrogativa que sobra para o pesquisador e para o bibliotecário, nessas circunstâncias, sob a contundência de cronogramas de projetos de pesquisa e desenvolvimento e de avaliaçóes acadêmicas e funcionais, respectivamente?

A quantidade de obras em línguas "exóticas", do passado, do presente e do futuro, que carecem de catalogação adequada, exige soluçóes urgentes, que dependem do compartilhamento de interesses, entre o pesquisador e o bibliotecário, centrados no fato de que a informação que está perdida deve ser difundida.

Essas soluções envolvem, por exemplo: 1 a identificação de anotaçóes manuscritas no livro impresso, de modo a distinguir as anotaçóes de bibliotecários das marcas de proveniência e de estudo, do próprio autor ou de usuários consecutivos; 2 o exame simultâneo e comparativo de exemplares de obras, para verificar incompletudes, delinear expectativas de longevidade e identificar alteraçóes de conteúdo e forma, impostas pelo tempo; e 3 a catalogação, propriamente dita, com a colaboração do pesquisador.

Se essas ou outras soluções não se efetivarem, as bibliotecas manterão coleçôes paralelas, não catalogadas ou processadas de modo imperfeito ou incompleto.

Enquanto isso, o pesquisador e o bibliotecário permanecem condenados a ansiar por "descobertas" em sua errância labiríntica, ladeados pelas musas que um dia inspiraram a ordem das bibliotecas e que ainda podem inspirar. 
Musas errantes:

Tesouros da Antiguidade Clássica no labirinto da Biblioteca Nacional Brasileira

\section{Bibliografia}

Albertinus, A. (1649), Ae. Albertini Emblemata Hieropolitica versibus et Prosa illustrabat Joannes Melitanus a Corylo eiusdem Musae Errantes. Coloniae: Apud Constantinum Munich (BNBr/OR214,002,015).

Báez, F. (2003), "Apogeu e fim da Biblioteca de Alexandria”, in História universal da destruição dos livros: das tábuas da Suméria à guerra do Iraque. Tradução Léo Schlafman. Rio de Janeiro: Ediouro: 61-73.

Battles, M. (2003), “Alexandria em chamas", in A conturbada história das bibliotecas. Tradução João Vergílio Gallerni Cuter. São Paulo: Ed. Planeta do Brasil: 28-60.

Chartier, R. (1997), A ordem dos livros. Tradução Leonor Graça. Lisboa: Passagens:109-110.

Dias, G. (2011), “Biblioteca de Alexandria: o helenismo e a dinâmica cultural dos judeus”, Humanitas 63: 217-223

IFLA (2009), Declaração de princípios internacionais de catalogação. Traduzido por Lídia Alvarenga et al. São Paulo: Federação Internacional de Associaçôes de Bibliotecários e Instituiçôes (IFLA)/UNESCO. Disponível em: <http://www.ifla.org/files/assets/cataloguing/icp/icp_2009-pt.pdf>. Acesso em: 05 ago. 2013.

Gesner, K. (1545), Bibliotheca universalis, sive Catalogus omnium scriptorum locupletissimus, in tribus linguis, latina, graeca, hebraica: extantium non extantiu, veterum recentiorum in hunc usque diem, doctorum indoctorum, publicatorum Bibliothecis latentium. Tiguri [Zurique]: apud Christophorum Froschoverum (BNBr/OR122,005,001).

Horch, R. (1985), Luzes e fogueiras: dos albores da Imprensa ao obscurantismo da Inquisição no Sacramental de Clemente Sánchez. Tese de doutoramento apresentada ao Departamento de História da Faculdade de Filosofia, Letras e Ciências Humanas da Universidade de São Paulo.

Manguel, A. (1997), Uma história da leitura. Tradução Pedro Maia Soares. São Paulo: Companhia das Letras.

McNeely, I., Wolverton, L. (2013), “A Biblioteca: 300 a.C.-500 d.C.”, in A reinvenção do conhecimento: de Alexandria à internet. Tradução de Maria Lúcia de Oliveira. Rio de Janeiro: Record: 19-48.

Pernoud, R. (1944), Lumière du Moyen Age. Paris: Bernard Grasset: 126-127.

Possevino, A. (1593), Bibliotheca selecta qua agitur de ratione studiorum in historia, in disciplinis, in salute omnium procuranda. Romae: Ex Typographia Apostolica Vaticana (BNBr/OR005,003,005).

Reyes Gómez, F. (2010), Manual de Bibliografia. Madrid: Castalia Instrumenta. 
Página deixada propositadamente em branco 


\section{Eudoro de Sousa e a Mitologia}

(Eudoro de Sousa and Mythology)

Diogo Ferrer

Universidade de Coimbra

(dferrer@clix.pt) 
Página deixada propositadamente em branco 
Resumo - Eudoro de Sousa, além de receber, estudar e interpretar o pensamento grego no espaço luso-brasileiro, encarna mais do que qualquer outro a recepção luso-brasileira dos clássicos. Mais do que qualquer outro pensador, elevou a recepção do pensamento grego a uma verdadeira assimilação. Os seus estudos não só dão especial atenção à mitologia e à filosofia pré-socrática, como procuram trazê-los a uma nova vida.

Palavras chave - mito, filosofia grega, pré-socráticos.

Abstract - Eudoro de Sousa received, studied and interpreted Greek thought in the luso-brazilian space. In his hands, the reception of Greek culture becomes a true assimilation. His studies not only give special attention to mythology and pre-socratic philosophy, but also try to bring these subjects back to life.

KEYwORDs - myth, Greek philosophy, pre-socratics.

Ao se falar, a partir da filosofia, acerca da recepção dos clássicos em Portugal e no Brasil não se poderia esquecer a figura de Eudoro de Sousa, cujo pensamento, bem mais do que receber, estudar e interpretar o pensamento grego no espaço luso-brasileiro, encarna mais do que qualquer outro a recepção luso-brasileira dos clássicos filosóficos e mitológicos gregos. Por um lado, foi um pensador essencialmente luso-brasileiro, nascido em Lisboa em 1911, formado em Lisboa, na Alemanha e em França, partiu para o Brasil em 1953, onde leccionou nas Universidades de São Paulo, Florianópolis e Brasília, cidade onde faleceu em 1987. O seu pensamento, apresentado em diversos artigos e conferências, encontra-se reexposto de modo extensivo e aprofundado em quatro obras fundamentais: Horizonte e Complementaridade (1975), Sempre o Mesmo acerca do Mesmo (1978), Mitologia (1980) e História e Mito (1981). ${ }^{1}$ Por outro lado, trazendo para a leitura e estudo filologicamente informados da filosofia grega e da mitologia uma linha de pensamento que passa, entre outros, por José Marinho, Eudoro de Sousa elevou a recepção do pensamento grego a uma verdadeira assimilação. Os seus estudos não só dão especial atenção à mitologia $\mathrm{e}$ à filosofia pré-socrática, como procuram trazê-las a uma nova vida. No Prefácio ao seu livro Mitologia, publicado inicialmente em 1980, lê-se que

1 Encontram-se reeditados em Eudoro de Sousa 2002 e 2004. Veja-se também, com diversos estudos sobre o tema, Eudoro de Sousa 2004b. Acerca do pensamento de Eudoro de Sousa poderiam destacar-se os seguintes estudos: Fernando Bastos 1992; E. A. de Soveral 2007, com informação biobibliográfica; Luís Lóia 2007; Fernando Bastos 2001; Dalila P. da Costa 2001; Paulo Borges 2002. 
"embora o livro se refira a mitos, clássicos ou náo", "o autor encara o conteúdo de seu livro como sendo, ele próprio, mitologia." 2

Esta compreensão do que deve ser a leitura e a interpretação dos mitos e do pensamento clássico ou também, para o caso, pré-clássico, é a marca filosófica do autor, que transformou a recepção do pensamento clássico numa filosofia original sobre a relação entre logos e mito, sobre o simbólico, o homem, a sua condição no mundo, a história, o Deus cristão e os deuses. Para Eudoro de Sousa, o pensamento filosófico é essencialmente recuperação da antiguidade e, nomeadamente, dos gregos.

Esta definição central da recepção dos clássicos permite-lhe, nos seus termos, "desengonçar", isto é, tirar dos gonzos onde gira, a generalidade do pensamento filosófico e da concepção do mundo ocidentais. A Grécia antiga não é um episódio na história do pensamento, mas o limite e limiar onde algo de decisivo para a compreensão do homem acontece. Com o pensamento pré-socrático e com a passagem a Platão, define-se a possibilidade de um novo tipo de concepçáo do passado e do presente, até então desconhecidos. Eudoro considera a história como uma sucessão de épocas, sem progresso ou regresso, ${ }^{3}$ que representam diferentes manifestaçóes da cultura.

Pode compreender-se a sua definição de cultura a partir do seguinte passo:

"o Projecto instituidor de homem e mundo (entrelaçados simbolicamente, se no entrelaçamento também se enlaça o Projecto, ou se referência de um a outro se faz só por referência de um e outro ao mesmo Projecto), possa ou náo possa ele passar por nós com o nome de Cultura - Cultura envolvida e ocultada por suas manifestaçóes, tal como homem e mundo envolvem e ocultam o Projecto que os instaura -, é abertura por onde irrompe um impensado vindo à presença de todo o pensar que se encontra em regime de disponibilidade." ${ }^{\text {”4 }}$

Para começar a ler Eudoro, deve registar-se desde logo que, de uma maneira que evoca fortemente o pensamento pré-socrático, cada passo do seu texto apela à interpretaçáo, a qual deve passar pela reflexão acerca de cada termo fundamental, muitas vezes grafado com maiúscula, e empregue de um modo que causa normalmente estranheza. Cada frase do autor

\footnotetext{
2 Eudoro de Sousa 2004: 21.

3 Cf. Eudoro de Sousa 2004: 235.

4 Eudoro de Sousa 2004: 32.
} 
constitui um discurso similar ao pré-socrático, onde um fragmento é fonte de inesgotável leitura e interpretação. A estranheza do uso dos termos no contexto em que Eudoro os emprega deriva de uma semântica que nos aparece, tomando em atenção as definiçóes e as concepçóes gerais do autor, como totalmente interior ao seu sistema de significaçōes.

Antes de passar à exposição do que o autor entende por mito e símbolo, deverá contudo começar-se pela compreensão do que compreende como horizonte e complementaridade, e qual a importância destes conceitos para a interpretação do humano e do mundo hoje - e sempre - na sequência do pensamento grego.

Eudoro parte da perda e do esquecimento actuais do horizonte resultantes "de mais de vinte séculos de reflexão filosófica e de investigação científica," que vieram a fazer esquecer a sua vivência originária. Filosoficamente, o horizonte é a definição fenomenológica por excelência de uma lei fundamental da determinação consciente, segundo a qual a condiçáo principal de que se veja algo de modo definido, ou seja, de o focar tematicamente, é a sua circundação por uma indeterminação não temática designada como horizonte. Este é o halo indefinido que institui o mundo focal da consciência, instituição que tem como exemplo privilegiado o tempo, em que o presente se define necessariamente como a intensidade do vivido, em oposição às modalidades menos definidas do passado e do futuro. E, por outro lado, o horizonte náo é uma linha objectiva, real, em sentido semelhante à que define os objectos iluminados dentro dele, mas um limite que é tanto do mundo quanto do nosso próprio olhar sobre o mundo. O horizonte é, assim, a própria correspondência da nossa visão e do nosso saber com o mundo objectivo.

Dois pontos centrais se podem realçar acerca desta concepção do horizonte. Por um lado, esta lei do horizonte diz-nos que todo o definido nasce a partir de um indeterminado. Por outro, insere todo o conhecimento temático num limite, que não é ocasional, mas constitutivo. Sem horizonte limitador e sem nocturno "além-horizonte", não há, nos termos de Eudoro de Sousa, tăo-pouco algum "aquém-horizonte" visível e diurno. Estas duas consequências do horizonte, o facto de que há um nascer, uma passagem a partir da obscuridade para as formas definidas do mundo habitável, e de que todo o saber é limitado, são ideias centrais no pensamento do autor sendo na verdade náo mais do que dois aspectos de uma mesma concepçáo do mundo e do homem.

\footnotetext{
5 Eudoro de Sousa 2002: 31
} 
A perda do horizonte é o que se iniciou desde os alvores do pensamento ocidental e significa, assim, que o saber simultaneamente perdeu todos os seus limites e deixou de se conceber como originado a partir do seu oposto, ou seja, que há algo que o antecede fundamentalmente. Isto que o antecede é, como se verá, o próprio mito e o símbolo como origem da significação que permitia constantemente religar aquilo que o horizonte separa, nomeadamente, o céu e a terra. E o horizonte é símbolo porque é a linha de junção entre céu e terra, entre o obscuro e o descoberto, é a limitação e a sua transposição, limes e limen. Esta transposição é a fonte primeira do símbolo e do significado no mito e, posto que o mito é historicamente o primeiro, também na história. A diferença entre o pensamento histórico que só tem presente, e o pensamento mítico, que é essencialmente passado, no que novamente história e mito coincidem, é acerca do modo como o passado é actual. Para Eudoro, a presença do passado é constitutiva, assim como o irracional é o alimento do racional. Este processo de criação do tempo encontra-se já numa das principais influências de Eudoro de Sousa tanto no que toca às concepçóes sobre a mitologia quanto sobre o tempo, a saber, Schelling. Para este

"o homem que não se superou não tem passado, ou, antes pelo contrário, não sai jamais do passado, vive constantemente nele. [...] Só o homem que tem a força de se arrancar de si mesmo [...] é capaz de criar para si um passado; e esse, justamente, desfruta também de um verdadeiro presente, e está propriamente perante um futuro." ${ }^{\prime 6}$

Este acontecimento criador do passado e do presente será representado, como veremos mais abaixo na análise da obra de Eudoro, por um acto de violência, que é tanto violência sobre si como sobre o si-mesmo que tem de passar a ser outro, a natureza.

Mas todo o saber filosófico, artístico, religioso e mítico depende da transposição do horizonte, de tal modo que, segundo Eudoro,

"desde a primeira transposição mítica até à derradeira transposição
metafísica da incógnita e talvez incognoscível vivência que situamos
no início da história e no limiar da consciência, o fascinante mistério
do horizonte sempre se nos revela em sua enorme espessura existencial."

6 W. F. J. Schelling 1968: 65. Acerca do próprio mito já como o limiar crítico da consciência filosófica, veja-se Schelling 1957: 20.

7 Eudoro de Sousa 2002: 33. 
O autor procura fundamentar a tese de que a origem do sentido está na conjunção e disjunção do horizonte pela pesquisa no corpus mítico da antiguidade grega, encontrando confirmaçóes desde Homero até ao pensamento platónico. De Homero, são as seguintes caracterizações: "parto a ver os limites da terra nutriz, o Oceano, génese dos deuses"; ou a referência ao "Oceano, que na verdade é génese de todas as coisas." Assim, conclui Eudoro, do horizonte-Oceano provêm os próprios deuses e todas as coisas, e o extremo é também o primordial no processo "teocosmogónico".

Mitologicamente, o horizonte remete para a separação entre Céu e Terra, que se encontra universalmente codificado na mitografia, sendo documentável em todo o mundo "- tribos africanas, Egipto antigo, Grécia moderna, literatura babilónica e judaica, Hurritas e Fenícios, na Índia, Sibéria, Ásia oriental," etc. ${ }^{9}$ Numa composição de espaço e tempo, antes e além do horizonte e, de certo modo, também ainda hoje, todas as noites, desde a sua separação e o sugimento da luz, Terra e Céu, vigília e sono são uma só e a mesma figura ainda indistinta.

Assim, além deste limite-origem está a indiferença entre Céu e Terra e, consequentemente, também da vida e da morte, "numa complementaridade que misteriosamente se oculta por detrás do horizonte." ${ }^{10}$ A filosofia pré-socrática dos fisiólogos vai codificar este horizonte, como arché e como o Indiferenciado, segundo Anaximandro. Mas é esta identidade do fenómeno nas suas duas codificaçóes que conduz o autor à tese do que denomina a "complementaridade" que, pela primeira vez, se atesta na relação entre o mito e o logos.

Segundo Eudoro, esta relação e passagem entre mito e o logos é, antes, uma permanente complementaridade, onde não há sucessão, mas duas codificaçóes distintas de uma mesma incógnita. Para lá do horizonte de visibilidade, vêm ao nosso encontro dois modos de grafar uma mesma vivência e uma mesma questão. Na complementaridade de Eudoro poderia encontrar-se também a tese adorniana, que vê num jogo de transformação especular, no mito já esclarecimento, e neste ainda o mito.

A tese de Eudoro acerca do surgimento da filosofia é que "a physis dos pré-socráticos nasceu subitamente como que do 'interiorizar-se', do 'recolher-se', do 'encerrar-se' de uma natureza que antes náo tinha dentro nem fora. [...] A natureza não teve dentro nem fora até ao dia em que alguma de suas

\footnotetext{
8 Ilíada, 14, 246, 302, cit. in Eudoro de Sousa 2002: 33, 34.

9 Segundo Staudacher 1942, cit. in Eudoro de Sousa 2002: 53.

10 Eudoro de Sousa 2002: 48.
} 
partes, algum dos seus membros, separando-se dela, ficou de fora." ${ }^{\prime 11}$ Esta parte e membro que ficou no exterior da natureza, a qual passou por isso a ter "fora" é, evidentemente, o homem. Por um lado, encontra-se aqui uma complementaridade pela qual a filosofia da mitologia não pode ser feita sem uma correspondente filosofia da natureza - no que Eudoro mais uma vez faz referência explícita a Schelling. Mas este processo de emergência do logos não se deterá numa natureza ainda povoada de deuses, e não descansará enquanto não os expulsar da sua morada na natureza e, assim, acabar por desfazer todo o sentido dos símbolos. Esta perda de sentido tem um primeiro momento na alegorização do símbolo evidenciada na catábase e vivência do horizonte na caverna de Platáo. O peculiar desta alegoria-mito platónica é que, ao contrário do que acontecia na codificação mítica, a instituição do "para lá do horizonte" provoca a degradação de todo o sensível situado "para cá do horizonte". Na codificação mítica o além do sensível não faz degradar o sensível, o que só acontece a partir de Platáo. ${ }^{12}$ Este é um primeiro passo no caminho da separaçáo do cosmos num mundo sem deuses e em deuses sem mundo, que irá culminar no mito do Homem, a priori de toda a cultura actual, e tanto mais fundamentalmente mito quanto menos se reconhece como tal.

Mas retornemos à caracterização do pensamento de Eudoro de Sousa pelo próprio autor, que pretende ultrapassar esta cisão instaurada desde Platão. O seu texto e pensamento, como começámos por referir, reivindicam para si o estatuto de mitológicos, na medida em que a mitologia deve ser concebida justamente como um aparente encerramento do discurso na lógica imanente das suas próprias definiçóes fundadoras. Eudoro recusa uma interpretação alegórica dos mitos, porquanto os mitos náo querem dizer outra coisa do que aquilo que dizem, tão pouco quanto a obra de arte ou os símbolos em geral podem ser interpretados desse modo alegórico. Não há que decifrar lá onde nunca se cifrou. $\mathrm{O}$ mito não deve ser explicado por traduçấo noutra coisa que significasse. Não faz sentido perguntar pelo significado de um mito

\footnotetext{
“a não ser que [...] a pergunta 'Que significa...?' se refira à significação que o mito confere, e não à que lhe é conferida. Quanto a mim, estou convencido de que um mito confere significação e que nada existe que lha confira a ele."13
}

\footnotetext{
11 Eudoro de Sousa 2002: 194.

12 Cf. Eudoro de Sousa 2002: 121-122.

13 Eudoro de Sousa 2004: 44.
} 
O mito dá significação "de dentro de si" ${ }^{14}$ e não a pode receber de fora. É verdade que, como origem de significação, ele pode dar voz a forças, fenómenos, "situaçóes-limite como o nascimento e a morte, as metamorfoses do homem", ${ }^{15}$ e outros dos dramas humanos no mundo. Mas a alegorização está, quanto à fonte da significação, sempre a jusante, a potência pertence primeiramente ao mito. $\mathrm{O}$ autor lembra, no entanto, que quase dois milénios de alegorização não podem ter sido em vão, razão por que a alegoria deve conter alguma verdade: a sua verdade não é que o mito deva dizer outra coisa senão o que diz, mas é a de fazer recordar que o mito não pode ser entendido separadamente do mundo e do drama que nele acontece, que o mito remete sempre para o mundo. O principal problema da alegoria é que não se recorre a ela para também "alegorizar o mundo", ${ }^{16}$ que fica então preso na sua "tautegoria" - ao passo que a função do mito é justamente a de alegorizar o mundo. A "abertura" e "disponibilidade" acima referidas seriam esta possibilidade de também alegorizar o mundo e encontrar a presença nele do impensado.

Para Eudoro, o pensamento dotado do que chama "disponibilidade" é precisamente um pensamento assim, na aparência fechado dentro das suas definiçôes fundadoras, que caberia ao leitor reabrir. Isto significa, por um lado, que o mito é cosmopoético. Não é, por isso, verdade, que cada entidade mitológica, um deus, por exemplo, manifestaria ou encarnaria um aspecto do mundo, força ou potência nele presente. ${ }^{17}$ Esta formulação não é admissível na medida em que ser "aspecto do mundo" faz do mito não mais do que, por assim dizer, um acidente de um mundo substancial, que se divide em aspectos ou modos. Segundo esta concepção que Eudoro critica, "a consistência é a do mundo", ${ }^{18}$ não a do deus, o que não está de acordo com o sentido da narrativa mitológica. Eudoro insiste em que esta narrativa é incompatível com a fundamental crença no mundo, como substância de que dependeriam estes supostos "aspectos". Assim sendo, acerca dos deuses e da sua relação com o mundo "melhor se diria: 'um deus é um mundo' e 'outro deus é outro mundo', em suma, cada deus munda, faz seu mundo do que ainda não o era - diacosmiza, numa palavra só." ${ }^{19} \mathrm{O}$ discurso mitológico é

\footnotetext{
14 Eudoro de Sousa 2004: 45.

15 Eudoro de Sousa 2004: 45.

16 Eudoro de Sousa 2004: 47.

17 Eudoro de Sousa 2004: 41.

18 Eudoro de Sousa 2004: 42.

19 Eudoro de Sousa 2004: 42.
} 
"diacósmico", tem a forma da "tautegoria" e aparece como auto-significante, porque conter-se a si mesmo no seu significado é característica própria do que chamamos um mundo. E assim, só pode ter a capacidade de aceder ao fundamental da racionalidade, do homem e do discurso, o pensamento que se dispóe como mitologia.

No entanto, deve-se, por outro lado, atender à própria noção referida de "regime de disponibilidade", a qual faz apelo a uma outra condição do discurso mitológico, que não a do seu encerramento semântico. O discurso simbólico não é de modo nenhum fechado no sentido de concluso, o que implica que a aparência de encerramento em si mesmo do discurso filosófico-mitológico é somente uma aparência. Pelo contrário, como a frase inicialmente citada nos adverte, "o Projecto instituidor de homem e mundo" é caracterizado pela "abertura" e pela "disponibilidade". A contradição desaparece na medida em que se admitir que o encerramento do discurso sobre si mesmo é o que permite que ele aponte para a sua fonte de significado, ou para o significado em geral do discurso. Pelo contrário, o discurso que Eudoro caracteriza de objectivador, próprio do logos raciocinante, é aquele cuja abertura se dá unicamente em direcção a objectos e a um mundo cujo horizonte de sentido é não só concluso, mas desconhecido de si mesmo como horizonte. Trata-se, no mito do pensamento pós-mítico, de ocultar a ocultação, pelo que o oculto é devolvido na crueza mais integral do poder fáctico impensado, que Eudoro encontra no mundo hodierno "diabólico" (justamente porque não "simbólico") dos objectos.

Eudoro insiste na diferença entre limite e limiar, limes e limen. O limiar é a disponibilidade aberta. Sem o conhecimento do horizonte não há sentido humano do discurso e, posto que todo o sentido e todo o discurso tem pelo menos um dos seus vértices no humano, sem o conhecimento do horizonte não há sentido do discurso. Assim, o sentido de todas as significaçóes é originalmente mitológico e por isso, o discurso filosófico que pretenda iluminar o horizonte de sentido é um discurso cuja estranheza apenas reflecte o facto de que o autor quer - mais do que comunicar, ensinar ou transmitir ideias - despertar.

O despertar é o tema do longo confronto que o autor apresenta, em Horizonte e Complementaridade, com o Fragmento 1 de Heraclito. Aqui se lê, na traduçáo de Eudoro, que

“este logos, sendo (como o enuncio), sempre o não entendem os homens, quer antes de o haverem escutado, quer após o terem ouvido. Pois, ainda que tudo suceda em conformidade com este logos, inexpertos parecem, mesmo que experimentem palavras e acçóes, tal como eu as exponho, distinguindo a natureza de cada uma delas e explicando-a 
tal qual é. Os demais homens, porém, táo pouco sabem o que fazem despertos, quão pouco se lembram de que fizeram dormindo." ${ }^{20}$

Despertar para o horizonte e o seu significado como limiar é o que o autor designa como a "transcendentização do horizonte próximo," ${ }^{21}$ ou também aceder à "trans-objectividade". Esta trans-objectividade significa "desencantar" os objectos mundanos, ir além da fixação definitória dos objectos até ao seu horizonte de sentido que, segundo Eudoro, é o horizonte do que denomina o "impensado". Aqui novamente reencontramos o topos adorniano de um esclarecimento que prossegue com o encantamento mítico do mundo, e cuja principal caracteristica de falsidade é a do mito que se mantém como poder actuante, mas não se enxerga.

Retomando a nossa questão inicial sobre aquilo que na Grécia antiga ocorreu de decisivo para a compreensáo do humano, recordamos que se tratava, para Eudoro, de compreender a história como sucessão de épocas sem progresso nem regressão. A história está submetida, vimos, ao "Projecto instituidor de homem e mundo". Note-se que o autor não refere a cultura a um projecto, mas ao Projecto, que parece designar em geral a instituição de homem e mundo segundo a referida exteriorização da natureza. Esta instituição é um processo que não é propriamente histórico, mas fonte de sentido de toda a história, o passado que acompanha o presente como a diferença que institui as épocas do tempo. Estas, especialmente o passado e o presente, não são entendidas como uma sequência linear simples, mas como um "projecto" que rege todo o acontecimento histórico. O tempo não é um simples movimento unidireccional, como numa linha que se prolonga indefinidamente, mas um complexo de estratos de significado diversificado.

O tempo começa, segundo Eudoro de Sousa, pela criação de um passado, que é mítico e, afinal, identifica-se com a própria natureza. Sempre na base do racional encontra-se o irracional. "A racionalização que por muito alongada para trás e para a frente de qualquer aqui e agora se pense sempre parte de um irracionalizado e sempre em um irracionalizado se detém." 22 A própria origem da história e da temporalidade se pode encontrar nesta criação de passado que, como horizonte, é o passado sempre presente da natureza, da sensibilidade e da mitologia. A mitologia não é, por conseguinte, nem alegoria, nem o representante de um estádio passado, ainda não esclarecido, da humanidade,

\footnotetext{
20 Eudoro de Sousa 2002: 130.

21 Eudoro de Sousa 2002: 132.

22 Eudoro de Sousa 2004: 37.
} 
mas a fonte sempre presente da correlação entre homem e mundo. $\mathrm{O}$ mito não é princípio, mas origem sempre presente de onde se alimenta a razão.

A instauração de homem e mundo acontece pelo culto ou pela dança, os quais, segundo Eudoro de Sousa, estáo na origem de toda a cultura e de todo o símbolo, mitológico ou outro. O projecto é o horizonte de possibilidades de sentido ou, segundo a terminologia do autor, "de um Drama que póe em movimento a acção de que o homem julga ter a iniciativa; o Projecto abre um leque de limitado número de possibilidades para lances (que nunca são originais) no jogo que o homem joga com o mundo e consigo mesmo." ${ }^{23}$ $\mathrm{O}$ jogo de sentido instaurador do mundo é simultaneamente, afirma o autor, a ocultação do projecto que está na sua base.

A tese da ocultação e do desvelamento do sentido no mito provém da concepção religiosa do mito fundamental que, segundo Eudoro, é o mito da origem. Eudoro busca encontrar o motivo do ocultar e desocultar de sentido do mito e de toda a linguagem simbólica no mito primordial pré-helénico da origem, segundo o qual o mito não é biografia dos deuses, mas thanatografia, narrativa da morte do deus como condição da posição do mundo e do homem mortal. O mundo e, com ele, todo o símbolo em geral é definido como "cosmofania teocríptica", que se vai estender até à palavra de Nietzche e Dostoiewski - mas primeiramente, antes destes, acrescente-se, de Hegel, - de que "Deus morreu". ${ }^{24}$ A origem do homem é o deicídio, já desde a mitologia aparentemente universal dos "Dema-Gottheiten (divindades-dema)" próprios dos povos sedentarizados pela agricultura.

Como exemplificativo desta tese, Eudoro apresenta o mito da ilha de Ceram, junto à Nova Guiné, narrado por Adolph Jensen. Segundo este mito, os homens eram originariamente deuses que, ao colaborarem num deicídio, permitiram a criação do mundo humano:

\footnotetext{
"outrora [...] deuses-homens dançavam uma dança que se prolongava por nove noites consecutivas [...], e ao fim da nona, em que finalizava a dança, os dançarinos que se dispunham em fila espiralóide, violentamente calcaram para dentro da terra uma moça que, no centro da espiral, e sem participar da dança, por todos distribuíra, noite após noite, bens cada vez mais preciosos. Na manhã seguinte, o pai, espantado pela ausência da filha, pôs-se em busca dela, e lá a encontrou moribunda, sob a terra, no centro do terreiro. A moça, que se chamava Hainuwele, ainda teve tempo de prescrever o destino do seu cadáver: que fosse cortado em
}

\footnotetext{
23 Eudoro de Sousa 2004: 42.

24 Cf. Eudoro de Sousa 2004: 49, 50.
} 
pedaços e esses fossem enterrados em volta do terreiro em que se celebrara a dança. Passado algum tempo, nos lugares em que tinham sido sepultados os pedaços do corpo de Hainuwele, nasciam, pela primeira vez, as plantas tuberosas de que se alimentam os homens da regiâo." ${ }^{25}$

Deuses comparáveis são Dioniso, Osíris, Átis, Deméter ou Perséfone. E, do mesmo modo, na narrativa babilónica de Gilgamesh encontra-se o mito da criação segundo o qual Marduk fez o mundo dividindo o cadáver de Tiamat, sendo por outro lado também a mutilação de Úrano por Crono na Teogonia de Hesíodo entendidos como equivalente à morte. $\mathrm{O}$ mesmo mito da origem pela morte do deus estaria presente ainda nas religióes "mistéricas" da antiguidade e constituiria o conteúdo afinal do próprio cristianismo. Com efeito, a morte de deus seria o motivo da mediação possível entre o mundo e os homens, por um lado, e os deuses, por outro, estando então na origem de toda a simbolizaçáo.

O mito cria o mundo não só no sentido da sua separação em relação ao homem e ao divino, mas também como segregação do passado que, viu-se, é instituído pelo mito. Este remete não para um passado mundano ou definível relativamente ao presente, mas a um outrora antes do mundo e dos homens como homens. Nos termos de Eudoro, "o Mito é a expressão da presença do passado, como a História é expressão da presença do presente", ou seja, é o que antecede toda a possibilidade de uma interpretação alegórica, que o autor define como "a transposição mortificante da sensibilidade para a inteligibilidade." ${ }^{26} \mathrm{~A}$ natureza, o sensível, o irracional são o passado de uma inteligibilidade que é presente histórico e mundo. $\mathrm{O}$ olhar do logos é sempre retrospectivo em direcção a uma unidade que já se diferenciou, e a irreversibilidade do passado é constitutiva do nosso próprio olhar distanciado da sensibilidade e da natureza. Por isso, o deicídio original tem também de ser a destruição da natureza como condição da construção do mundo humano histórico, mundo de onde se perdeu a perspectiva simbólica, substituída pela tautegoria do mundo que é o mito como alegoria.

Todo o símbolo, segundo Eudoro, é "triangular" correspondendo a uma ligação indissociável entre homem e mundo, na base do triângulo, e um deus no vértice. A tese de Eudoro acerca do projecto pelo qual se desenvolveu a história e a relação entre coisas e símbolos, que permite entender o desenvolvimento do pensamento a partir da Grécia antiga, é que o vértice

\footnotetext{
25 Eudoro de Sousa 2004: 81.

26 Eudoro de Sousa 2004: 348.
} 
do triângulo desapareceu como "aceno" do divino, tendo os dois lados colapsado numa simples linha de que está ausente toda a verticalidade.

Sem que se possa agora explorar mais além o valioso diagnóstico que Eudoro de Sousa faz do homem contemporâneo, imerso no mito sem mito dos objetos encantados, refira-se apenas que a principal ameaça ao seu sentido é a desintegração do simbólico. Esta destruição do simbólico é vista por Eudoro, por um lado, a partir da oposição entre símbolo e coisa e, por outro, com base na oposição entre 'simbólico' e 'diabólico'. A primeira oposição é remetida para uma diferença entre a "desintegração do símbolo" que unicamente constitui a coisa, e a "reintegração da coisa" que constitui o símbolo e a restitui a um mundo habitável. Assim, as "coisas são pedaços dispersos de símbolos diabolicamente destruídos. ${ }^{27} \mathrm{O}$ diabólico das coisas é o crítico e separador que não desencanta propriamente o mundo, como se referiu, mas, pelo contrário, que o encanta $\mathrm{e}$ faz perder o seu sentido num mundo "fragmentado em 'coisas' separadas." ${ }^{8}$

E porque o discurso simbólico e mitológico não admite encerramento ou conclusão, permito-me concluir com uma citação acerca das "coisas-só-coisas" que resultam da sua desintegraçáo "diabólica" resultante do achatamento do triângulo simbólico:

\begin{abstract}
“as 'coisas-só-coisas' não se nos apresentam e não se representam senão por virtude do libreto que o Diabo escreveu, e a 'peça que ele nos pregou' foi a de nos fazer acreditar que seja essa a única que os homens [...] desempenham no Mundo [...] que ele negativamente criou. Agora já sabemos o que significa esse 'negativamente': é a negação do simbólico; por afirmaçáo persistente e insistente de que o Homem pode e deve recusar-se a ver na coisa que ele é, e na coisa que é o Mundo, mais do que a deliberada tendência de um a outro se ligarem por vínculos que, sendo apenas externos, facilmente se quebram ao sabor do nosso soberano arbítrio."${ }^{29}$
\end{abstract}

A recepção dos clássicos permite pois a Eudoro de Sousa uma reconstrução de todo o percurso da história ou do "projecto" desde o mais antigo mito da origem, ou mesmo mais atrás, no culto e dança pré-simbólica ainda até ao arbítrio soberano de um mundo composto por coisas sem efectivo vínculo a coisa alguma, onde, no seu diagnóstico, se situa um homem desintegrado, como só mais uma coisa.

\footnotetext{
27 Eudoro de Sousa 2004: 107.

28 Eudoro de Sousa 2004: 124.

29 Eudoro de Sousa 2004: 111.
} 


\section{Eudoro de Sousa e a Mitologia}

\section{Bibliografia}

Bastos, F. (1992), Mitologia e Filosofia: Eudoro de Sousa e a complementaridade do Horizonte. Brasília: Editora da Universidade.

Bastos, F. (2001), "As Posiçôes Filosóficas de Eudoro de Sousa", in Mito e Cultura: Vicente Ferreira da Silva e Eudoro de Sousa. Lisboa: Instituto de Filosofia Luso-Brasileira: 113122.

Borges, P. (2002), "Do perene regresso da filosofia à caverna da dança e do drama iniciático. Rito e mito em Vicente Ferreira da Silva e Eudoro de Sousa”, in Pensamento Atlântico. Lisboa: INCM: 413-425.

Costa, D. P. (2001), "Horizonte e complementaridade em Eudoro de Sousa", in Mito e Cultura: Vicente Ferreira da Silva e Eudoro de Sousa. Lisboa: Instituto de Filosofia LusoBrasileira: 133-144.

Lóia, L. (2007), O essencial sobre Eudoro de Sousa. Lisboa: INCM.

Schelling, W. F. J. (1957), Einleitung in der Philosophie der Mythologie. Darmstadt: WBG.

Schelling, W. F. J. (1968), Die Weltalter, in Schriften von 1813-1830. Darmstadt: WBG.

Sousa, E. de (2002), Horizonte e Complementaridade: Sempre o mesmo acerca do mesmo. Lisboa: INCM.

Sousa, E. de (2004), Mitologia, História e Mito. Lisboa: INCM.

Sousa, E. de (2004b), Dionisio em Creta e outros Ensaios. Lisboa: INCM.

Soveral, E. A. (2007), "Eudoro de Sousa” in Calafate, P. (Dir.), História do Pensamento Filosófico Português: O século XX. Tomo I. Lisboa: Círculo de Leitores: 297-315.

Staudacher, W. (1942), Die Trennung von Himmel und Erde. Eine vorgrieschicher Schöpfungsmythus bei Hesiod und die Orphikern. Tübingen: Bölzle. 
Página deixada propositadamente em branco 


\section{Câmara Cascudo em Defesa de Epicuro}

(Câmara Cascudo defending Epicurus)

Markus Figueira da Silva

Departamento de Filosofia da Universidade Federal do Rio Grande do Norte

(markus@cchla.ufrn.br) 
Página deixada propositadamente em branco 
Resumo - Em seu livro Prelúdio e Fuga do Real, Luiz da Câmara Cascudo dedica um capítulo a Epicuro, no qual apresenta uma análise do pensamento ético do filósofo helenista, destacando a incompreensão deste pensamento pelo senso comum. O cerne da análise cascudiana é o sensualismo de Epicuro que aparece matizado pela frugalidade que se opóe à imagem de dissoluto que erroneamente foi divulgada ao longo da história. O que se busca aqui é argumentar em torno da apresentação que Câmara Cascudo faz da ética de Epicuro, evidenciando a coerência deste pensamento e a sagacidade do seu intérprete brasileiro.

Palavras chave - literatura brasileira, recepção, epicurismo.

Abstract - In his Prelúdio e Fuga do Real, Luiz Câmara Cascudo, in a chapter dedicated to Epicurus, offers an analysis on the ethical thought of the Hellenistic philosopher, underlining the general incomprehension about it. The main point in Cascudo is Epicurus' sensuality combined with a frugality that contradicts his traditional image of dissolution. This article aims to explore the interpretation Cascudo makes of Epicurus, and to make clear the sagacity of the Brazilian interpreter.

KeYwords - Brazilian literature, reception, Epicureanism.

Câmara Cascudo ambienta o seu conto "Epicuro. Do prazer sem os sentidos" num cenário fictício e anacrônico, mas com elementos e nomes reais. Assim a cena tem lugar no Hotel Belvedere, em Nova York, lugar frequentado por pessoas que figuram no hall da fama e que cultivam a imagem - ou aparência - mas que são descritas como "técnicos da intranquilidade universal" ". Vê-se desde o início do texto a descriçẫo dos modos de vida excêntricos e imoderados, típicos daqueles que buscam cultivar a fugacidade e construir artificialmente uma glória forjada em aparentes honrarias, tal como fazem certos políticos que se acham deuses, artistas que um dia sentiram esperança de se tornarem famosas.

Toda descrição detalhada desse cenário preconiza o principal foco da abordagem cascudiana da crítica que Epicuro faria das apropriações indevidas do seu pensamento, que resultaram na ampla e criminosa divulgaçáo distorcida da sua imagem na História da Filosofia. Na verdade a descrição das personas que frequentam o hotel póe em evidência as crenças ilusórias e as vấs opinióes que povoam o vazio que sustenta, imaginariamente, a conduta dessas pessoas. Antevê-se os modos de vida marcados pela ausência de discernimento (phrônesis), aqueles que sempre foram objeto da crítica epicurista, os incapazes de perceber a alternativa apontada por Epicuro

\footnotetext{
1 Câmara Cascudo 1974: 25.
} 
para este modo de vida ilusório e intranquilo, que aprisiona os ignorantes nas amarras de uma condição de vida artificial e sem porvir. Somente no sétimo parágrafo, Cascudo inicia a descrição da personagem central do conto, Epicuro de Samos, filósofo grego que viveu entre 341 e 270 a. C.:

Cabelos de prata, olhos negros, perscrutadores, lento, majestoso, alheado, vestido de escuro, folgado e cômodo, como um Doctorof Divinity. Folheia, indiferente e maquinal, as publicaçôes do living room. Fuma um cachimbo de barro branco, com saboreado vagar, olhando longe, através do parque, molhado de chuva, ou dourado de sol... um "jequitibá em planícies de jurubebas²."

Percebe-se já nessa descrição a imagem de Epicuro construída a partir dos dados recolhidos na leitura do livro X das Vidas e Doutrinas dos filósofos Ilustres, de Diógenes Laércio, que certamente foi a sua principal fonte, seguida do poema De Rerum Natura, de Lucrécio, nas versōes francesa e italiana. Contudo o que nos interessa na sua leitura e na sua interpretação é o humor com que escreve a sua séria defesa do pensamento de Epicuro contra "mais de vinte séculos de deformação intencional e visão de escândalo", como ele mesmo asseverou ${ }^{3}$. Devemos chamar a atençáo para o personagem, um professor aposentado de uma universidade americana, aqui identificado a Epicuro, que se encontra no saguão do hotel fazendo um comentário sobre um volume de História da Filosofia que tem nas mãos: "veja que os gregos estão quase legítimos" e "Epicuro, quase verdadeiro", acrescentando que Epicuro "é o mais inverídico dos filósofos". O professor, isto é, Epicuro, mesmo que fictício, acrescenta que "o falso Epicuro é proveitoso aos seus adversários”. Perguntamos então: quais adversários? E a resposta vem a seguir: "peripatetas, estóicos, sofistas e platonianos, enriquecidos depois pela convergência sonora da loquela cristã".

Outra informação colhida de Diógenes Laércio é a produção de mais de trezentos livros que desapareceram e Cascudo explica as razóes desse desaparecimento:

"Ele (Epicuro) não tivera as transcrições simpáticas que Sócrates mereceu de Platão", e ainda: "Ficou sendo a égide das tendências inferiores

\footnotetext{
2 Cascudo 1974: 25

3 Cascudo 1974: 26.

4 Cascudo 1974: 26.
} 
e sujas, impotente suíno fuçador de detritos e lameiros humanos, devoto do ventre e de falos... filósofo das orgias e bacanais." 5

É como se Epicuro soubesse da infame caricatura que a maledicência registrou ao longo de toda história até o momento que ele, Epicuro, resolveu falar como personagem de Cascudo. Prova disso é o que Cascudo encontrou nos dicionários quando buscou o verbete Epicurismo: "Teoria de requintes, fruição utilitária, volúpia incessante dos sentidos”. Então ele deu voz a Epicuro para se defender:

"Prazer! Razão de viver! Da vida, nada levamos. Prêmios, castigos, julgamento, suplícios, sấo inexistências criadas pela má digestão do agape. Alma é uma função orgânica, como o fígado. Dissipa-se na morte. Entregue seu tempo aos instintos aprazíveis. Deixe o mando, governo, poder, para as vocações prisioneiras da angústia!" ${ }^{6}$

Cascudo é irônico quando se refere às barbaridades que disseram de Epicuro e do Epicurismo. Ele pondera que nada compreenderam, porque não tomaram conhecimento do pensamento genuíno de Epicuro. O que divulgaram foi apenas a imagem que divulgaram do filósofo, por isso decreta que a partir deste momento o personagem Epicuro se declarará e falará de si e do seu pensamento na primeira pessoa, para mostrar o alcance que teve e o porquê de ter servido em momentos distintos de emblema difamador daqueles que, posteriormente, assumiram e divulgaram as suas ideias:

"Sou Epicuro de Samos, filho de Aristóbolo e Cherestrata, sábio de Atenas. Fui o primeiro grego afirmando-se com esse título. Os senhores não antepõem o douto, o doutor, ao nome próprio?” 7

Quando o personagem Epicuro se revela ao leitor, revela também que se transportou no tempo para uma cena contemporânea, vivida por Cascudo, leitor voraz de tudo que chegou até ele. A ficção possibilita um olhar retrospectivo que exibe o contraste entre os estudos sérios da filosofia antiga e a falsa imagem divulgada para fomentar a ignorância e servir os interesses da "convenção e da malícia", como afirmou em sua autodefesa.

\footnotetext{
5 Cascudo 1974: 26.

6 Cascudo 1974: 26-27.

7 Cascudo 1974: 27.
} 
Cascudo cita Ubertino de Cezara e Erasmo de Rotterdam como vítimas políticas e ideológicas, o primeiro considerado herege e o segundo chamado pejorativamente por redimir Epicuro de toda essa difamação; só em 1889, Hermann Usener publica a sua Epicurea, "maciça comprovação e colheita do resto que de mim existe, mesmo parcialmente desfigurado, não poderia evitar a continuidade da avalanche estrondeando perfídias". (27). O que se nota é que Cascudo não tem o objetivo de forjar semelhanças entre Epicuro e os estóicos, nem tampouco "cristianizar" o pensamento epicurista como fez Francisco de Quevedo em $1635^{\circ}$. Náo creio que Cascudo tenha tido acesso a essa obra, mas de todo modo a sua intenção, além de satirizar a maledicência como bobagem servil da ignorância, foi mostrar como Epicuro gostaria de ser apreciado pelos leitores e qual a sua real importância. Assim ele tematiza, resumidamente, os principais pontos da filosofia epicurista, segundo a leitura de comentadores que se apoiaram nas fontes textuais genuínas, a saber: o livro $\mathrm{X}$ da obra de Diógenes Laércio e o poema De Rerum Natura, de Lucrécio, além da doxografia e das citaçóes recolhidas por Usener.

Mesmo com o esforço dos estudiosos do pensamento de Epicuro e da reuniáo dos textos remanescentes da sua obra, o que resta é muito pouco e Cascudo sugere qual a opinião de Epicuro sobre os seus escritos na atualidade:

\footnotetext{
"Não creio ser possível reconstruir todo o navio pelo aproveitamento dos destroços salvos. Quanto à sua essência incorruptível há, ou resiste, mais do que suficiente para a evidência, justamente o inverso da imagem divulgada" ?.
}

O que Cascudo denominou "essência incorruptível" diz respeito à physiología e à ética epicurista. Diversos comentadores concordam que é notória a influência do atomismo antigo no desenvolvimento da ciência moderna em diversos aspectos, assim como é reconhecida por diversos pensadores a importância da ética de Epicuro, preservada nas assertivas da Carta a Meneceu, das Máximas Principais e das Sentenças Vaticanas. A questão fundamental da ética é o modo de vida sábia, onde a physiología é a pesquisa acerca da natureza das coisas e define-se como exercício contínuo que caracteriza a prática filosófica no Jardim. Neste sentido, o modo de vida sábia

\footnotetext{
8 Quevedo 1986.

9 Cascudo 1974: 28.
} 
preconiza o kathá physin, que significa viver de acordo com a natureza. Os estudos sobre o epicurismo, em particular sobre a prática de vida de Epicuro, evidenciam a simplicidade, a frugalidade da vida na comunidade epicurista. É o que assevera o Epicuro de Cascudo:

"Já disse que tivera contra mim os herdeiros de Aristóteles e de Platão, sofistas loquazes e estóicos teatrais. Vivi setenta e um anos de equilíbrio, prudência, comedimento. Por convicção, que a vacilante saúde colaborara, fui homem frugal...” ${ }^{10}$.

Ele fala de si e da vida que levou, da sua magnanimidade em libertar os escravos e doar o Jardim aos amigos para a continuidade do modo de vida que concebera e cultivara. Diz que a sua escola fora dos muros de Atenas "possuiu duração tranquila" "11, mesmo tendo vivido em uma época de perseguiçóes e tormentos, como ele relata a seguir:

"Não seria crível essa tolerância para um escolarca do vício e da subalternidade moral. Sócrates e Pródico beberam cicuta. Protágoras morreu, fugitivo, no mar. Aristóteles conheceu o exílio. Vivíamos no caos que a morte de Alexandre Magno determinara. Seus generais fundavam reinos com espada e sangue. Os descendentes de Alexandre foram trucidados pelo crime dessa perturbadora ascendência. Ninguém interrompeu minhas aulas à margem d'água corrente, sob sombras mansas e longas" ${ }^{12}$.

Ainda sobre o modo de vida epicurista, diz a descrição cascudiana na voz do personagem Epicuro:

"Os epicuristas não seriam heróis nem mártires, mas sábios, gente humana, valorizando a calma, alegrias da convivência letrada, a suprema volúpia do entendimento, que era a compreensão e renúncia às formas troantes da tempestade administrativa, econômica, guerreira" ${ }^{13}$.

\footnotetext{
10 Cascudo 1974: 27.

11 Cascudo 1974: 28.

12 Cascudo 1974: 28.

13 Cascudo 1974: 28.
} 
a) Aspectos do pensamento de Epicuro evidenciados por Câmara Cascudo.

Em primeiro lugar, a physiología e a gnoseología, o exercício da compreensão da phýsis com vistas à realização da vida sábia. Cascudo inventa um Epicuro que justifica a diferença que marca a sua postura investigativa frente a outros pensadores. Mostra a coerência e a lucidez de Epicuro quando aponta o sentido prático e conveniente da physiología e da gnoseología por ele concebidas.

\begin{abstract}
"Os aristotélicos, platônicos, estóicos, sofistas e cristãos ensinavam e ensinam que a ciência, física ou moral, deve ser servida pelo homem, submetido permanentemente aos seus impositivos como a um deus exigente, imperioso, implacável. Eu (Epicuro) inverti os termos da proposição. A ciência (physiología e ética) deve estar em serviço do homem, ampliando as dimensões inteligíveis da existência, ou não será ciência alguma. Fora do humano, do perceptível e útil, cognoscível pelos sentidos, verificável pela repetição experimental, nada interessará nossa cogitação. O sol terá milhóes de formas ativas no universo, mas para nós ilumina, aquece, fecunda a terra... Fixemo-nos na terra, tratando de viver sem os problemas do sofrimento. Bastam os do próprio organismo pessoal"14.
\end{abstract}

Cascudo mostra o que o interessou na leitura dos textos filosóficos de Epicuro e da sua biografia composta por Diógenes Laércio. Ele se posiciona a favor de Epicuro por este não desvincular o conhecimento da sua realização prática, nem da sua conveniência, ou utilidade (sympheron). Ele também mostra sua aprovação do modo de vida indicado por Epicuro, traçando um perfil claro da ética epicurista, a começar pela afirmaçáo da autarkeía, isto é, da defesa desta noção fundamental para a conquista e para o exercício da liberdade (eleuthería) do sábio. Cabe ao sábio ser autárquico, ou seja, ter o princípio da ação nele mesmo. Só assim poderá escolher e recusar, o que em essência é a sua liberdade. Libertar-se dos temores provocados pela ignorância e alimentados pelas opinióes vazias.

"Viva e deixe os outros viverem! o espírito é ansioso e móbil, mas além da física, do corpo, dos átomos, existe unicamente a dor do mistério. Notadamente no plano do sobrenatural influindo na movimentação humana"15.

14 Cascudo 1974: 28.

15 Cascudo 1974: 30. 
A physiología constitui um exercício de busca pelo saber que possa dar ao homem a sua ataraxia (imperturbabilidade da alma). Escolher pensar a phýsis e evitar acreditar nos mitos. É o exercício da Physiología que livrará o sábio dos temores que o atormentam e assim ele tornará a sua vida esclarecida e aprazível. A sabedoria atuará como um phármakon, isto é, como um tetraphármakon, prescrevendo o modo de agir com sensatez e discernimento frente aos temores da alma. Epicuro afirmou que "não há nada a temer em relação aos deuses", como o primeiro dos quatro remédios e Cascudo defende Epicuro da acusação de impiedade, resultado dessa afirmação:

“-Não! Não neguei os deuses. Ignorei-os apenas como dispensáveis grandezas na humildade da terra. $\mathrm{O}$ senhor não acha ridícula essa frase? Combater, negar os deuses? A devoção e a incredulidade são valores puramente humanos. Não alcançam a divindade infinita que deles independe. Que alteração substancial terão os deuses com a nossa estima ou negativa? Viverão pela nossa fé?" 16

Cascudo enfatiza que para o personagem Epicuro, na sua visão retrospectiva, "a face reprovada do epicurismo, a mais frágil da doutrina", é a moral. ${ }^{17} \mathrm{E}$ continua a defesa em forma de justificativa:

"Não incluí os deuses porque ainda permanecem difusos, confusos, complexos, para os humanos... o conhecimento dos deuses é um mistério sem iniciaçấo"18.

Curiosamente Cascudo não reconstrói os preceitos acerca da morte e da dor, que compóem, junto com os deuses e o prazer, o tetraphármakon. Contudo, ele realça a recusa da política e propóe uma definiçâo epicurista da moral. No primeiro caso, Epicuro se defende da acusação de "indiferença precavida" ${ }^{19}$ em relação ao poder político e aos negócios públicos, nestes termos:

"Vivendo em época demagógica, recomendei abstenção partidária aos meus discípulos... Pítaco, aisenmeta de Mitilene, depois do decênio

\footnotetext{
16 Cascudo 1974: 31.

17 Cascudo 1974: 32.

18 Cascudo 1974: 31.

19 Cascudo 1974: 31.
} 
recusou reeleição, alegando: - é difícil proceder bem até o fim!" ${ }^{20} \mathrm{E}$ continua: "A tranquilidade intelectual vale uma dúzia de coroas de reis. Quem acredita nessa compensação? Unicamente os verdadeiros discípulos de Epicuro. Os demais atrelam ao carro dos negócios-públicos. Tornam-se públicos negócios...” ${ }^{21}$

Cascudo demonstra nutrir uma especial simpatia pelo modo de vida cultivado por Epicuro, sobretudo pela recusa do sábio em participar da vida pública e preferir "viver ignorado (lathe biósas)" (Epicuro/Us. 327-8)22. Parece compreender que a Atenas de Epicuro já não era livre e que a liberdade possível dependia do cuidado de si, do exercício da autarkeía. Por isso insiste na defesa da sua ética:

"Dispus a moral como elemento autônomo do céu e da terra, independente de retribuição econômica, sobrenatural ou repressiva. Uma entidade autárquica, bastando-se a si mesma. Recusando troféus e não temendo o inferno. Agindo com a naturalidade da respiração... causando prazer no seu simples exercício pessoal... Homem sem moral era organismo sem o músculo cardíaco"23.

Ele chama a atenção para a importância que teve a ética epicurista, por ele chamada de moral, em seu tempo e exime-se da responsabilidade sobre as interpretaçóes forjadas pela crítica tendenciosa daqueles que adulteraram o propósito da conduta sábia de Epicuro;

"Não é novidade, professor! É doutrina exposta entre 304 e 270, antes de Cristo, em Atenas. Não me cabe culpa da mudança ou dilaceração do invólucro. A finalidade humana é o prazer! Não o passageiro, efêmero, imediato, e que provocará o sofrimento, miséria, enfermidade, como um excesso de festim, de erotismo ou de ambição. Não vivemos para a renúncia, penitência, martírio" ${ }^{24}$.

\footnotetext{
20 Cascudo 1974: 31.

21 Cascudo 1974: 31.

22 Silva 2003: 94.

23 Cascudo 1974: 34.

24 Cascudo 1974: 35.
} 
Assim começa o último ponto da defesa que o Epicuro de Câmara Cascudo faz do seu próprio pensamento. A defesa do bem primordial e congênito, da noção de hedoné.

"O prazer para nós é o prazer contínuo e tranquilo, a calma da sabedoria (phrónesis) acima dos furores da paixão animal, prazer da fruição moral, íntima, suficiente ao ser racional"25.

Ele enaltece a noção de hedoné katastematiké, ou o prazer em repouso, que deixa a alma serena, conforme a imagem da superfície do mar em calmaria, definido na noção de galenismós.

"O homem, mesmo imperfeito e carecente, projeta e constrói a sua felicidade (makários zén), o prazer relativo ao júbilo da sua vida intelectual, desambiciosa, sorridente, modesta, recatada, fora da batalha dominadora"26.

Entretanto, a outra imagem forjada pelos detratores do epicurismo contrasta totalmente com aquela "ataraxía ambicionada e benéfica, a paz imperturbável e soberana" ${ }^{27}$. Eles inverteram o propósito dos ensinamentos e da prática de vida epicurista reconhecida por Cascudo pela frugalidade ética em oposição ao desperdício político ${ }^{28}$.

Por fim, o personagem Epicuro de Samos se despede do seu interlocutor dizendo o que pretendeu com a sua prática filosófica centrada no ideal de vida sábia, afirmativa do prazer:

“- Pretendi revelar a cada ser humano sua força interior, espiritual, capaz de fazê-lo encontrar-se, bastar-se, jamais sentir-se isolado, sozinho, desamparado... Não sonhei reformar uma sociedade, mas fortalecer o elemento essencial da componente, dar-lhe vigor, compreensão, ternura para as coisas simples e vitais. Outros prometeram a perfeição na terra ou a felicidade no céu. Eu apenas ensinei a encontrar-se a tranquilidade..." ${ }^{29}$

\footnotetext{
25 Cascudo 1974: 35.

26 Cascudo 1974: 35.

27 Cascudo 1974: 35.

28 Silva 2003: 95.

29 Cascudo 1974: 36.
} 
Markus Figueira da Silva

\section{Bibliografia}

Cascudo, L.C. (1974), Prelúdio e Fuga do Real. Natal: Fund. José Augusto.

Laércio, D. (2008), Vidas e Doutrinas dos Filósofos Ilustres. Brasília: UNB.

Lucrécio, T. (1964), De la Nature. Paris: Les Belles Lettres.

Quevedo, F. (1986), Defensa de Epicuro contra la comúm opinión. Madrid: Tecnos.

Silva, M.F. (2003), Epicuro, sabedoria e jardim. Rio de Janeiro: Relume Dummará. 


\title{
Medéia carioca
}

\author{
(Medea carioca)
}

Luísa Severo Buarque de Holanda

Departamento de Filosofia, PUC-Rio

(luisa.severo@terra.com.br) 
Página deixada propositadamente em branco 
Resumo - Este artigo pretende contribuir para a reflexão a respeito das obras artísticas como uma importante modalidade de recepçáo dos clássicos, com um estudo de caso: o exemplo da transformação sofrida pela Medeia de Eurípides ao ser transportada para o Brasil do século XX na peça teatral Gota d'Água, tragédia carioca dos anos setenta que se inspira na grega para, declaradamente, pensar a realidade política, social e econômica do país na época.

PAlavras Chave - Eurípides, convenções trágicas, realidade brasileira.

Aвstract - This article is a contribution to the reflexion about artistic creations inspired by classical paradigms, focused on a particular case: the changes suffered by Euripides' Medea being adapted to Brazilian culture in the $20^{\text {th }}$ century. Gota d'Água is a 'carioca' tragedy of the twenties inspired by the Greek one, in order to think about political, social and economic reality of the country at that moment.

KEYWORDS - Euripides, tragic conventions, Brazilian reality.

Em 1975, C. Buarque e P. Pontes escrevem, publicam e encenam no Rio de Janeiro o drama Gota d'Água, recriação musical, poética e teatral da Medeia de Eurípides. A obra é claramente uma livre adaptação da trama euripideana. Ela leva a ação para um conjunto habitacional carioca, faz dos protagonistas da tragédia genuínos brasileiros do século $\mathrm{XX}$, acrescenta-lhes ainda dezenas de outras personagens, modifica-lhes os destinos, propóe-lhes outro desfecho, em suma: intervém na trama original tanto quanto necessário para os propósitos autorais, simultaneamente artísticos e políticos. As intervençóes levadas a cabo pelos autores de Gota d'Água fazem pensar nessa particular modalidade de recepção dos clássicos que constituem as adaptaçóes artísticas em geral. Elas exigem, grosso modo, uma compreensão rigorosa de seus pontos de partida, mas também o abandono dos mesmos para que possam se tornar recriaçóes esteticamente relevantes. Fidelidade e traição - ou, como se costuma dizer proverbialmente, tradição, tradução e traição - são exigências que, num caso bem sucedido, devem trabalhar em conjunto, e não em oposição. Minha proposta neste artigo consiste em contribuir, ainda que muito modestamente, para a reflexáo a respeito das obras artísticas como uma importante modalidade de recepção dos clássicos, com um estudo de caso: o exemplo da transformação sofrida pela Medeia de Eurípides ao ser transportada para o Brasil do século XX na referida Gota d'Água, tragédia carioca dos anos setenta que se inspira 
na grega para, declaradamente, pensar a realidade política, social e econômica do país na época ${ }^{1}$.

A começar por algumas consideraçóes bem gerais a respeito do texto brasileiro, seria necessário, antes de mais nada, justificar o fato de que o enredo de Eurípides, e não um outro qualquer, foi escolhido para falar da "trágica realidade brasileira" - como afirmam os autores da peça em Apresentaçáo oferecida na edição do texto e escrita ainda no período de ensaios. Ora, em meio ao "mundo de intençóes" ${ }^{2}$ contidas nessa reinvenção brasileira de Eurípides, encontram-se três preocupaçôes fundamentais, explicitamente declaradas pelos autores. A primeira e mais importante delas, na qual irei me fixar, é a seguinte: a denúncia da "radical, violentamente predatória, impiedosamente seletiva" ${ }^{3}$ experiência capitalista que se implantara no Brasil com o dito milagre econômico dos anos setenta. Ela elevara ao paroxismo a já brutal concentração de renda na sociedade brasileira e, ainda segundo os autores, adquirira um trágico dinamismo, que leva a revolução industrial inglesa a se assemelhar a um "movimento filantrópico, se comparado com o que se fez para acumular o capital do milagre" . Na declaraçáo dessa primeira preocupação, claro está que o termo 'trágico' é entendido em sentido lato. Não se trata de um gênero literário, nem tampouco da tragédia enquanto performance teatral: não se trata nem mesmo da cultura grega. Trata-se de um desastre social, promovido por meio de uma aliança entre medidas econômicas injustas e o autoritarismo político. Em poucas pala-

1 Eu jamais teria pensado em fazê-lo, não fosse pela belíssima palestra da Professora Maria de Fátima Souza e Silva, Medeias Portuguesas, que versava sobre algumas relevantes adaptaçóes do clássico euripideano em Portugal no século XX, mostrando suas mais diversas motivações e iluminando seus contornos. Não tenho como agradecer suficientemente a ela pelo ponto de partida que me ofereceu de presente, bem como pela fecunda interlocução que se seguiu à oferta. Aproveito para agradecer também à Maria das Graças de Moraes Augusto e à Maria do Céu Fialho pela organização, junto com a própria Maria de Fátima Souza e Silva, do II Colóquio Pragma/IEC, onde tive a oportunidade de apresentar a primeira versão deste trabalho e de ouvir comentários instigantes. Agradeço ainda a todos os colegas participantes do Colóquio pelos maravilhosos trabalhos que apresentaram.

2 Buarque e Pontes 1975: xi.

3 Idem.

4 Ibidem. A segunda das intenções é revelar o problema cultural que decorre dessa situação: o fato de que as camadas populares desapareceram paulatinamente da produção cultural brasileira. E a terceira reflete-se formalmente na obra, sobretudo pela escolha da versificação, que "intensifica poeticamente um diálogo que podia ser realista" (Buarque e Pontes 1975: xix): trata-se da valorizaçáo da palavra, instrumento mais capaz de pensar a complexidade da situação que se pretende denunciar. 
vras: triste, desastrosa, infeliz, sem saída e sem rumos era a situação social brasileira, e essa era a nossa tragédia, que a peça pretende "olhar de frente" Nesse sentido, é interessante notar que, em toda essa longa introduçáo que desfia cuidadosamente as preocupaçóes centrais da obra, permanece elíptica a escolha da tragédia como forma literária, do autor Eurípides e da peça Medeia. Esta última nunca é mencionada, exceto por uma única e singela vez: quando, já nos agradecimentos finais, é citada a adaptação para a TV de Medeia, feita por Oduvaldo Vianna Filho, que inspirara a recriação teatral e fornecera "a indicação de que na densa trama de Eurípides estavam contidos os elementos da tragédia que queríamos revelar". Implícitos, portanto, permanecem os motivos que levaram os autores a transformar Medeia em Joana, a protagonista da nova versão. Apenas se constata que, no percurso da personagem, a tragédia social brasileira ganha corpo em uma tragédia carioca.

Não obstante, desnecessário seria adentrar os meandros de tais motivos, haja vista que, à medida que se avança na leitura da obra brasileira, se confirma o que fora entrevisto no drama de Eurípides: antes de mais nada, a possibilidade de tematizar um confronto entre o poder político e econômico - amparado por leis fabricadas em proveito próprio - e as ditas "classes subalternas"7. O centro das atençóes está, não nos conflitos que se desenrolam na trama original, nem em questôes formais ligadas ao gênero poético utilizado, mas na possibilidade de denúncia contida na espinha dorsal da trama euripideana: Medeia, a mulher atraiçoada e expulsa pelo poder tirânico, contra Jasão, o homem que "ama o estreito liame com tiranos", o pai que "prefere a noiva aos filhos" e que é norteado mais pelo lucro do que pela justiça ${ }^{10}$.

Destarte, a leitura brasileira do clássico converte Creonte no representante das autoridades autoritárias - com o perdão pela necessária redundância - que concentram poder e riquezas. E Medeia se transforma em Joana, passando a simbolizar a camada humilhada da população, que, já "por aqui, perto de explodir, um trem que atrasa, ele mata, quebra mesmo, é a gota

\footnotetext{
5 Buarque e Pontes 1975: xv.

6 Idem: $x x$.

7 Ibidem: xi.

8 Eurípides, Medeia 700. Utilizo aqui, para todas as citações do drama grego, a tradução de Trajano Vieira, 2010.

9 Medeia 88.

10 Cf. a fala do pedagogo, 85-88.
} 
d'água" ". Jasão, por sua vez, torna-se o homem talentoso que, oriundo das camadas populares, é cooptado pelo grande promotor e representante de nosso capitalismo caboclo, de novo Creonte. Como visa a denunciar a dupla de autores, há algo de politicamente diabólico em um sistema de seleção que privilegia alguns poucos capazes e utiliza suas melhores e mais vívidas energias em prol da eficiência da engrenagem, agora cada vez mais forte e mais capaz de esmigalhar os outros milhares deixados para trás (e isso, aliás, talvez seja o que mais contribui para o orgulho ferido de Joana, haja vista que fora ela a plasmar, com suas mais excelentes forças, esse 'melhor' que agora a deixa para trás, assim como fora Medeia a verdadeira responsável pelo sucesso de Jasão na conquista do velo de ouro). Por tal motivo, Jasão desempenha na adaptação o papel daquele que, antes colocado de fora "perigosamente, no limite da rebeldia" ${ }^{12}$, como uma ameaça latente, agora usa todo seu potencial para contribuir para o status quo ao qual foi assimilado. (Aliás, não será esse o destino mais freqüente de tudo o que representa a desordem: ser incorporado de modo atenuado à ordem mais geral?).

Por meio desse breve resumo, já é possível perceber que as significativas mudanças levadas a cabo pela adaptação do enredo grego à realidade brasileira da época estáo longe de se restringir à atualização do mito como um todo ${ }^{13}$. Poder-se-ia mesmo reafirmar que se trata de uma obra apenas levemente inspirada no drama original e desistir assim da indócil empreitada comparativa. Não obstante, parece-me que há algo nessa adaptação que resiste às mais evidentes diferenças entre a obra inspiradora e sua reescritura. A fim de elucidar tal resistência, proponho encarar as referidas transformaçóes a partir de um ponto de vista específico: o tratamento dado à protagonista do enredo, a personagem da Medeia-tornada-Joana (cuja análise será precedida de um breve panorama das caracterizaçóes das outras personagens centrais - Creonte e Jasão - sem as quais seria impossível compreender plenamente as transformações sofridas pela protagonista). Trata-se, portanto, de desfiar algumas comparaçóes entre a personagem euripideana e a sua encarnação carioca, de modo

\footnotetext{
11 Buarque e Pontes 1975: 94.

12 Idem: xiv.

13 O exemplo mais marcante é a mudança do desfecho: a Medeia brasileira não consegue realizar seu intento de matar Creonte e sua filha, e por isso mata seus dois filhos e se suicida em seguida. Seria possível citar também outras transformações significativas, a título de exemplificação: a multiplicação das personagens, a mudança de ênfase e a subversão da estrutura cênica; seria preciso, por outro lado, pensar também na manutenção da versificação, da música, da dança e do canto. Se o coro não mais existe stricto sensu, ele continua existindo na voz das vizinhas e dos vizinhos.
} 
a elucidar em que pontos suas características originais se prestavam, e em que pontos não se prestavam ao objetivo geral pretendido pela adaptação do mito trágico. Em suma, trata-se de focar Medeia enquanto personagem, não enquanto enredo. Isso se justifica pelo fato de que, nas escolhas dos autores em relação às personagens, ao que nelas se mantém e ao que se lhes acrescenta, torna-se mais claro o propósito geral da adaptação, até o momento apenas vislumbrado pelas consideraçóes iniciais tecidas na Apresentação.

A começar por Creonte - que tem pequena participação na trama original e se torna em Gota d'Água uma das personagens centrais, e verdadeiro antagonista - já havíamos notado que seu papel na adaptação é o de representante da trágica exploração dos trabalhadores em prol do lucro desmedido. Proprietário de conjunto habitacional, Creonte vende casas por um preço aparentemente módico que, corrigido com base em cálculos incompreensíveis, cria dívidas infindáveis. Demagogo cínico e incapaz de abrir mão de qualquer coisa que seja de seu interesse individual, o Creonte brasileiro inspira nada mais do que antipatia e indignação - na melhor das hipóteses um riso de escárnio. Na Medeia grega, pelo contrário, a posição tirânica de Creonte não parece ser fortemente tematizada, ou ao menos não parece estar no centro dos interesses gerais ${ }^{14}$. Muito mais ressaltada é a atitude em certo sentido egoística de Jasão, ao aproximar-se da filha do rei, do que um possível autoritarismo inerente à decisão de Creonte ao exilar Medeia por questóes pessoais - decisão, aliás, em momento algum comentada pelas outras personagens da trama. Além disso, sua hesitação em dar a Medeia mais um dia, e sua desconfiança de que não fizera o certo ao lhe conceder tal favor, são plenamente justificadas ao findar o drama. A Medeia grega - nesse momento astuta e dissimulada - já tramara sua vingança e apenas representava um papel. Creonte tinha razão ao temê-la. A verdadeira tensão da peça de Eurípides, portanto, encontra-se muito mais na relação entre Medeia e Jasão do que na relação entre Medeia e Creonte. No drama brasileiro, por força de denunciar um sistema que a todos fixa em posiçóes

14 Em uma ocasião me parece que a posição do tirano aparece como um abuso de poder. Trata-se do verso 309, em que Medeia afirma: "Que condição teria para agir contra quem reina?" E em seguida, no v. 315: "Mesmo por baixo, calo, pois me vence um forte.” Ao que o próprio Creonte, pouco à frente, responde com um singelo: "Tiranizar não casa bem comigo" (v. 348). Esse diálogo de fato coloca em cena a posição social de Creonte. No entanto, esse assunto não é central na peça como um todo e, mesmo na referida ocasião, a ênfase recai sobre a dissimulação da protagonista, que apenas finge se submeter à vontade de Creonte. De todo modo, pouco se sabe, e pouco importa saber, sobre o caráter e os sentimentos de Creonte na trama euripideana. 
pré-definidas, e pela necessidade de simbolizar esse sistema na posição de Creonte, o ponto de vista deste último se torna injustificável. O plano fracassado de Joana, que tenta matar Creonte, mas não consegue, é quase que lamentado pelo espectador, junto com a personagem.

Muito mais complexas são, nesse sentido, as transformaçóes sofridas pela personagem de Jasão, já que a sua posição parece ter sido usada como a chave da conversão do poema trágico grego em tragédia brasileira. Mantém-se, em parte, o conflito original de sua relação com Medeia: o ódio vingativo da personagem central em contraposição aos ponderados e até certo ponto sensatos projetos e conselhos de seu ex-marido. Em conseqüência disso, muito das falas e das intenções de Jasão é reaproveitado. Por exemplo, quando ele mostra a Medeia, no original, e a Joana, na adaptaçáo, o quanto ela mesma fora responsável por sua própria destruição; o quanto uma atitude mais controlada teria resultado em proveito próprio ${ }^{15}$. Mantém-se também, por outro lado, a impressão geral de "cinismo, ambição e calculismo"16 das suas palavras e dos seus atos. Ou melhor, da predominante contradição entre suas palavras e seus atos. Por mais generoso que seja seu discurso, ele acaba traindo as intençóes mais obscuras (como, por exemplo, quando oferece dinheiro para que Medeia/Joana possa partir com dignidade, o que também ocorre em ambas as tramas ${ }^{17}$ : ali, expóe-se a sua necessidade de

15 Medeia 448-450: "Preservaras moradia e status quo, submissa ao que os mais fortes sentenciavam. Tua fala verborrágica é a única culpada pelo exílio.” E 455-458: “Eu tentava amainar a ira régia, sonhando com a tua permanência, mas destilavas fel contrária a quem domina a pólis: eis por que te exilam.” E também 622: “Altiva, agravas o difícil.” Em Gota d'Água, 122: "Esse teu temperamento agressivo e insuportável... Ficasse num canto, com um gênio melhor, mais compreensivo, você ia viver aqui a vida inteirinha. E talvez nem precisasse pagar."

16 Palavras usadas pelo tradutor T. Vieira para caracterizar Jasão (Posfácio à Medeia, 2010: 158). Essa caracterização de Jasão, entretanto, não necessariamente é unânime. Alguns a corroboram lembrando, por exemplo, que Jasão não mantém seu juramento, grande falha no que diz respeito aos códigos de ética helênicos. Outros lembram, por outro lado, que suas razóes estão em pleno acordo com o que se esperaria na época de um homem responsável (cf. a Introdução à tradução francesa de Medeia por M. Gondicas e P. Judet de la Combe, 2012). Parece-me, de todo modo, que a ambigüidade talvez seja proposital.

17 Buarque e Pontes 1975: 122: "Hoje mesmo, pode ir se mudando, que eu te garanto, eu fico te pagando todo mês uma espécie de pensão..." E Eurípides, 610-611: "Se desejas amparo pecuniário para cruzar fronteiras com teus filhos, é só dizer que estou às ordens!" Também no original de Eurípides, quando Jasão tenta convencer Medeia de que se casara com a filha do rei pensando nela e nos filhos: 593-597 "Póe na cabeça de uma vez por todas: não foi por outra que subi ao leito régio, mas por querer salvar a ti e aos dois meninos, pai de irmãos dos filhos de agora, príncipes, bastiōes do alcácer”. 
pensar e dizer que foi magnânimo e, ao mesmo tempo, corroborar a ordem de Creonte; matéria para mais ódio da parte de ambas as ex-mulheres, sempre altivas e incapazes de receber migalhas).

Em contrapartida, o papel a que Jasão precisa se prestar na adaptação talvez exija muito mais simpatia em relação à personagem, da parte do público, do que exige o Jasão original. Se a versão brasileira tem o intuito de ressaltar a perversidade do sistema que coopta e perverte, abafando toda possível rebeldia, torna-se muito útil perceber e explicitar as razóes de Jasão. Por tal motivo, ele possui uma complexidade de sentimentos que não caberia que tivesse na trama original. Veja-se, por exemplo, a fala dele para Joana em seu último encontro, quando finalmente se revelam suas justificativas íntimas para ter abandonado a mulher ("Você tem uma ânsia, um apetite que me esgota. (...) Pra você náo há pausa, nada é lento, pra você tudo é hoje, agora, já, tudo é tudo, não há esquecimento, não há descanso nem morte náo há. (...) Foi por isso mesmo que eu te amei tanto, porque, Joana, você é um inferno. Mas agora eu quero refresco, calma, o que contigo nunca consegui, nunca, nem um minuto". ${ }^{18}$ ). O Jasáo de Eurípides, pelo contrário, só ganha mais decisivamente a simpatia do público quando Medeia começa a perdê-la, na parte final da peça. E isso ocorre justamente quando ficam mais claros - ou ainda, para que fiquem mais claros - os temas centrais abordados pela tragédia euripideana. É aí que se revela finalmente, em seu ápice e grau máximo de intensidade, aquilo que até entáo estivera apenas entrevisto: os conflitos de perspectivas. Entre homem e mulher ${ }^{19}$, grego e bárbara ${ }^{20}$, civilizado e selvagem ${ }^{21}$, contençâo e desmedida, sensatez

18 Buarque e Pontes 1975: 125-126.

19 Os exemplos de comentários a respeito da condiçáo feminina ao longo da peça de Eurípides são inúmeros. Escolhi apenas alguns deles a título de exemplificação: 230, "Entre os seres com psique e pensamento, quem supera a mulher na triste vida?", 250, "Empunhar a égide dói muito menos do que gerar um filho", 407-409, "Tens ciência; ademais, a raça fêmea ignora como haurir algo elevado, sábia quando edifica o horror do fado.", 573-575, "Pudéramos procriar diversamente e preterir a raça das mulheres: imune ao mal, o homem viveria!".

20 Alguns exemplos: 591: "O que te preocupava era que núpcias bárbaras te infamassem na velhice.", 1330, "Faltou-me percepção ao propiciar a troca de uma casa em terra bárbara por residência em território helênico".

21 Alguns exemplos: 535-539, "Me explico: teu logradouro é grego, não é bárbaro, prescindes do uso cru da força bruta, não ignoras justiça e normas"; 1336-1343: "Foi o princípio, pois às núpcias comigo sucederam os meninos, dizimados por causa de uma cama, algo impensável entre as moças gregas, mas minha escolha recaiu em ti - uniáo atroz, funesta para mim...” 
e insensatez ${ }^{22}$, ambos tiveram as suas razóes e desrazóes. Mas Medeia, definitivamente, foi longe demais - essa parece ser a impressão final. E é aí que Jasão - que de fato fora no mínimo ingrato e perjuro com aquela que fizera de tudo para acompanhá-lo e vê-lo vencer - começa a poder justificar suas observaçóes. Por trás de suas palavras parece ressoar o raciocínio de que ele deveria ter esperado nada menos do que o infanticídio de quem já fora capaz de trair o próprio pai, matar o próprio irmão e provocar a morte do tio do próprio marido. E a perplexidade geral, compartilhada por público e personagens, de alguma maneira corrobora o seu raciocínio. O resultado final é que, na peça grega, assistimos a um grande confronto de pontos de vista (sendo talvez essa uma das mais distintivas marcas da tragédia ática): nenhum deles pode ser abraçado integralmente sem que se perca algo, justamente porque todos eles têm sua plausibilidade. Cada personagem expóe e defende ferozmente uma perspectiva que é, em si, até certo ponto defensável, não fosse pelas açóes parciais que acaba por engendrar. Ao fim e ao cabo, portanto, todos são em alguma medida derrotados, sendo a ruína o mais incontornável signo do processo vital.

Ora, tendo em mente as comparaçóes entre as posições de Creonte e de Jasão nas duas obras analisadas, estamos finalmente em condiçóes de abordar a transposição de Medeia para Joana, que aqui mormente me interessa. É no desenvolvimento de sua perspectiva que se encontram reinterpretados, ao que parece, os temas centrais da peça grega, arrolados logo acima. E é na análise dessa personagem que se torna claro, por fim, que a adaptaçáo brasileira da tragédia euripideana faz mais do que apenas aquilo que fora anunciado em sua Apresentação.

Em primeiro lugar, retomemos as dicotomias supracitadas, que se encarnam na Medeia e no Jasão de Eurípides: ele, o homem, ela, a mulher; ele, o Heleno, ela, a estrangeira; ele, o civilizado, ela a bárbara; ele, o sensato, ela a insensata; ele, agindo pelo cálculo frio, ela, cujo cálculo é guiado pelo ódio. Note-se, aliás, que cálculo e ódio estão entre as mais importantes características de Jasão e de Medeia, respectivamente; o cálculo gera egoísmo e ingratidão, marca das açóes de Jasão e do que delas decorre (segundo Trajano Vieira, Medeia "registra o desequilíbrio entre o que propiciou a Jasão e o que dele recebeu, e esse desequilíbrio lhe provoca sentimento de deson-

22 Ex.: 1358-1368: "Medeia: ...fiz o que devia ao te atingir no íntimo!” (...) "Jasão: Matar por uma cama, que ousadia!" "Medeia: Para a mulher, não é uma quimera." "Jasão: Para as sensatas, é. Não tens limite.” 
ra, desencadeando a atitude vingativa"23). O ódio vingativo, por sua vez, é responsável pelo desatino das açóes de Medeia e pelas suas infelizes conseqüências; embora todo o plano de vingança seja cuidadosamente calculado, é o ódio quem guia e governa o cálculo da protagonista. Por fim, e como que a reforçar tais dicotomias, note-se que toda a descrição da personagem de Medeia está perpassada pelo registro da violência irrefreável, e isso não apenas nas palavras de seu antagonista Jasão. Desde o início, pela boca da nutriz, passando pelas cenas com o coro de mulheres de Corinto $^{24}$, até os momentos finais de confronto com Jasão, todos os comentários acerca do comportamento de Medeia (e não somente o atual, mas também o habitual) são perpassados pelo vocabulário da fúria e da ira. Muito comuns são palavras como orgé e seus derivados, para me restringir a um único exemplo.

Entretanto, é preciso sublinhar o fato de que essa fúria não a torna incapaz de raciocinar. Pelo contrário, Medeia é a sábia - domina segredos e fabrica poçóes - e é pelo raciocínio que trama e efetua o mais inesperado, e por isso mesmo mais eficaz, plano de vingança contra Jasão $0^{25}$. Não se trata, por conseguinte, de uma simples exclusão do raciocínio pela emoçáo, mas de uma manipulação do raciocínio pela emoção ${ }^{26}$. É no exato momento em que ela se vê tomada pelo mais profundo ódio que Medeia invoca e investe

23 Vieira 2010: Posfácio à tradução de Medeia, 168.

24 Exemplos: 39-40: "Conheço-a de longa data e não descarto a hipótese de que apunhale o fígado...”; 44-45: "Ela é terribilíssima. Ninguém que a enfrenta logra o louro facilmente"; 93-95: "Se a conheço bem, sua fúria só alivia se fulmina alguém que, espero, não seja um amigo"; 103-105: "É crua em seu jeito de ser; o íntimo da mente altiva horripila”; 174-175: "Cede o frenesi de seu ânimo, o coração fundo-colérico?” Registre-se que todos esses exemplos fazem parte do início da peça, ou seja, contribuem para a apresentação do caráter da personagem.

25 Vieira 2010: 157-176, ressalta que um dos adjetivos mais utilizados para qualificar Medeia é saphé (segundo ele, encontrado 23 vezes ao longo da obra). Medeia é sábia, e sua sabedoria tem a ver não apenas com os fármacos que sabe administrar, com essa espécie de feitiçaria bárbara, mas também com o ineditismo de seu ato, que se confunde com o ineditismo da invenção trágica do próprio autor Eurípides, como ressalta T. Vieira. O sábio arrojo de Medeia, que mata os próprios filhos, ação imprevisível até para os mais imaginativos (e sua imprevisibilidade contribui enormemente para a eficácia do plano), é na verdade a sabedoria do poeta, que ousa inventar açáo nova e imprevista para a velha personagem. $\mathrm{O}$ tradutor desenvolve minuciosamente esse ponto de vista ao longo de todo o seu estudo.

26 O controverso passo $1077-80$ de seu solilóquio indica, ou uma exclusão da razão pela emoção, segundo alguns intérpretes, ou um domínio da razão pela emoção, segundo outros. Eu pendo para a segunda interpretação; porém, de todo modo, a argumentação não repousa necessariamente sobre essas linhas específicas. 
a sua capacidade de raciocínio, arregimentando todo o arsenal de sabedoria que ela supõe, na execução de seus nefastos e fúnebres projetos.

Os próprios gregos reconheciam essa estrangeira como sábia. Pensavam, além disso, que seu barbarismo havia sido aniquilado e substituído pelos costumes equilibrados da civilização helênica. É o que mostram, dentre outros, os versos em que Jasão lhe diz: "Me explico: teu logradouro é grego, não é bárbaro, prescindes do uso cru da força bruta, não ignoras justiça e normas. Gregos, unânimes, aclamam: 'Sapientíssima!'”27 Ser grego, como de costume, é ser civil e obedecer a normas e leis, e Medeia parecia ter se tornado uma grega, pela convivência. Mas esses que confiam em sua sapiência descobrem, afinal, da forma mais crua e incivilizada, que a mesma sabedoria em urdir tramas que havia sido empregada para o sucesso de Jasão fora agora aplicada em sua ruína. Outrora dominada, talvez, pelo amor, agora certamente dominada pelo ódio, mas sempre sábia, sempre segura, sempre a seu modo também calculada, Medeia usa deliberadamente o racional em prol do irracional, e o irracional em prol do racional. Ou melhor, alia racional e irracional como uma força única, que mostra que a máxima pujança do ser humano ocorre, não quando ele sufoca as paixóes em proveito da razão, mas quando ele potencializa a razão pela paixão, e vice-versa.

O cálculo orientado pelo ódio e devotado a ele mostra, portanto, que a força selvagem de Medeia fora apenas temporária e parcialmente sufocada. A linguagem euripideana revela, nesse sentido, uma intenção muito clara de evidenciar a natureza bruta, a selvageria explícita do gesto assassino de Medeia. Por meio da exploração da simbologia animal, tão recorrente na obra como um todo, torna-se exposto o caráter para sempre bárbaro da protagonista. Ora touro ("taurivoraz"28 e, em seguida, com "olhar de toura"29), ora "leoa que mira o avanço dos servos no pós-parto" ${ }^{30}$, segundo as palavras da nutriz; ora Cila ("natura acídula que obnubila até a tirrena Cila" ${ }^{11}$ ) e de novo leoa ("leoa, e não mulher"32 e "leoa algoz de prole"33) na boca de Jasão, o fato é que Medeia é aos olhos de todos uma besta não domesticada, incontrolável e voraz.

\footnotetext{
27 Medeia 535-539.

28 Medeia 92.

29 Medeia 188.

30 Medeia 187.

31 Medeia 1343.

32 Medeia 1342.

33 Medeia 1407.
} 
Em suma, parece-me lícito afirmar que existe no drama grego uma ambigüidade em relação a Medeia que não deixa de ser uma ambigüidade em relação às fêmeas em geral. Medeia é a um só tempo humana e animal, o que de alguma forma equivale a dizer: feminina. Ser bárbara, e não grega, já equivale em certa medida à acusação de ser bicho, e não gente. Ser mulher, e não homem, já é quase o mesmo. Ser mulher grega, no entanto, de alguma maneira atenua a acusação (ver, por exemplo, a resposta de Jasão à ex-mulher: o seu gesto é "algo impensável entre as moças gregas"34). Porém, Medeia, a estrangeira sábia e em aparência domesticada pela grecidade, era antes considerada quase um homem, ou ao menos quase uma mulher grega. Ao fim e ao cabo (tendo usado a sua sabedoria para cumprir o irracional com a máxima racionalidade), torna-se ao mesmo tempo mais mulher e menos grega ${ }^{35}$, e mais besta e menos mulher.

Não obstante, Medeia se torna tanto mais paradoxal quanto mais se nota que, para impor a força de sua bestial feminilidade, a personagem precisa refrear justamente aquilo que, dentro dela, mais fala a favor do feminino, a saber: o amor materno. O conflito interno de Medeia, o seu "ser dividido" 36 entre a voz maternal e o heroísmo destrutivo, ou seja, entre o feminino e o masculino, ao qual Foley se refere em conhecido artigo, termina, aparentemente, em uma preferência pelo masculino, ou na decisão de ser como um homem. De fato, a pendência de Medeia para a vingança viril, heróica, máscula, não deixou de ser notada desde o célebre trabalho de Knox, que observa particularmente que a Medeia vingativa pensa e atua como um herói arcaico ou sofocleano quando enganado. Foley, seguindo a mesma linha, observa que Medeia "possui o individualismo teimoso, a intransigência, o poder, a selvageria quase bestial e a falta de piedade de tais heróis ameaçados" ${ }^{37}$. E acrescenta que, ao referir-se a sentimentos ligados ao amor maternal, a heroína taxa-os de macios, moles, fracos, ou seja: femininos. É preciso, evidentemente, dureza para levar a cabo seus planos. Quando ela vacila, é porque está sendo demasiadamente fêmea.

\footnotetext{
34 Medeia 1339.

35 Lembremos dos versos supracitados em que a própria Medeia afirma para si mesma que a ciência das mulheres nâo funciona quando se volta para o bem, mas é eficaz para realizar o terrível: 407-409, "Tens ciência; ademais, a raça fêmea ignora como haurir algo elevado, sábia quando edifica o horror do fado.”.

36 Uma referência ao título do artigo de Foley, 1989.

37 Foley 1989: 75.
} 
Todavia, me parece também que o ilogismo lógico dos planos de Medeia jamais deixa de ser feminino em seus mais íntimos desígnios ${ }^{38}$; ela se lamenta pela condição feminina e a recusa, tomando a decisão de tornar-se um homem para enfrentar o homem que a havia ludibriado; mas, em todo caso, sua vingança consiste, em grande parte, em mostrar a Jasão o quanto uma mulher forte, sábia e viril pode levar a cabo uma vingança muito mais cruel do que a de um homem. A bestialidade e a selvageria de um herói épico ou trágico costumam ser diretas: Aquiles a rodopiar em torno de Tróia arrastando o corpo de Heitor, ou Ájax delirando, a supostamente assassinar seus inimigos, são homens atuando no âmbito da guerra, batendo-se objetiva e diretamente contra quem os humilhou ou feriu. Trata-se de uma brutalidade da violência viril, inteiramente distinta da brutalidade da violência doméstica a que Medeia se dedica. Em primeiro lugar, a heroína de Eurípides escolhe fins em si tortuosos: atingir Jasão pela destruição de quem está à sua volta, deixando-o em deserto solitário semelhante ao que ela mesma antevia para si. Suas razóes, ademais, são inteiramente ligadas ao âmbito feminino helênico: vingar uma traição erótica (ver, por exemplo, 1367-8, quando Jasão pergunta se ela decidiu matar os filhos por causa de uma cama, e Medeia responde que esse não é um motivo pequeno para uma mulher); e, de quebra, revoltar-se contra a sua condição vitimizada. Os meios de realizar tais objetivos, por sua vez, são os mais femininos possível (dentro de uma compreensão ali cuidadosamente construída): a astúcia e a dissimulação, as lágrimas e a súplica quando convence a todos de seu arrependimento; o veneno, arma de mulher-bruxa sapiente; os presentes de casamento, preocupação feminina (como mostra Mueller em seu artigo sobre as tramas da personagem ${ }^{39}$ ); e, finalmente, o peplos, resultado da arte feminina da tecelagem.

Em última instância, talvez fosse lícito considerar que toda heroína trágica, quando não age pelo sacrifício de si em prol do marido, da família, ou

38 Refiro-me, evidentemente, a uma determinada compreensão do feminino que a peça parece sutilmente corroborar. Mas seria preciso também lembrar que, como nota Gagnebin, “...esta famigerada 'feminilidade' nada tem de essencial, exceto uma função determinada num discurso que procura estabelecer a sua coerência e a sua verdade..." Gagnebin, 1997: 43.

39 Todo o artigo de Mueller, 2011, gira em torno da memória de Medeia, e de como a destruição do novo casamento de Jasão é ao mesmo tempo uma referência ao seu próprio casamento no passado, e um fim do mesmo. Ver, particularmente, p. 471. Ela mostra também, detalhadamente, como os presentes de núpcias articulam-se com a memória da personagem, e com sua feminilidade. 
da comunidade, é de algum modo masculina, ao menos aos olhos das outras personagens. Já que a mulher não tem 'voz pública', ser protagonista de uma história trágica já é ser como um homem. Antígona o é, Clitemnestra o é, Medeia também o é. Conseqüentemente, todas elas, ao se revoltarem contra uma ação pontual qualquer, revoltam-se ao mesmo tempo contra a dominação masculina, de modo que, na tragédia, a maneira mais pregnante de ser mulher é de alguma forma masculinizar-se. Mas isso não equivale necessariamente a dizer que, para levar a cabo a sua vingança, Medeia sacrifica a sua feminilidade. Matar os próprios filhos, no contexto do drama, acaba sendo de uma bestialidade feminina - de meandros tortuosos e, por isso mesmo, inesperados - marcando a única maneira possível de essa mulher, tornada bicho feroz, mostrar-se mais forte do que o homem que a traíra ${ }^{40}$. E é também assim, mais uma vez paradoxalmente, que a personagem faz jus à sua filiação divina: borrando as fronteiras entre homem e mulher, grega e bárbara, humana e animal, Medeia termina semi-deusa, e celebra sua penosa vitória do alto, da posição que apenas a sua linhagem de helíade teria permitido fazer. Medeia nega, afinal, a sua feminilidade e o seu barbarismo, tornando-se exclusivamente o que só ela - esta Medeia particular, distinta de todos e de todas em seu radical isolamento - pode ser.

Pois bem, o que é retomado com força e intensidade em Joana, essa Medeia brasileira que aqui me interessa, é precisamente o traço de caráter mais propriamente feminino, mais paradoxalmente bestial e mais pungentemente bárbaro da protagonista de Eurípides. Mulher com "gênio de cobra" e "dada a macumba"41, que canta a "fúria dos animais"ł2, Joana reapresenta ao seu modo a sabedoria a serviço da odiosa vingança. Ela própria afirma, com a mesma espantosa lucidez de sua ancestral grega, que "a mulher é uma espécie de poltrona que assume a forma da vontade alheia”43, e, mais à frente, diz ter a impressão de que se encontra em um desses momentos em que "quem pensa por você é o nervo exposto", quando "só o que

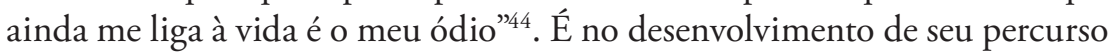

40 A uma possível leitura de que o ato de Medeia é um gesto de proteção aos filhos (argumentação presente na boca da própria personagem), eu acrescentaria que também neste caso ele pode ser lido como bestial, no sentido de que tem algo de um bicho-fêmea protegendo seus filhotes, imagem, de resto, também presente na peça euripideana.

41 Buarque e Pontes 1975: 39.

42 Idem, 69.

43 Ibidem, 60.

44 Ibidem, 112. 
que surgem, portanto, os desdobramentos dos conflitos entre feminino e masculino, selvagem e civilizado, animal e humano, em larga medida presentes no original euripideano ${ }^{45}$.

Entretanto, é exatamente na apropriação dos temas euripideanos, e na proximidade entre as duas protagonistas, que se mostra ao mesmo tempo a distância das abordagens. Muito embora as dicotomias se mantenham, com suas correspondentes simbologias, e as duas protagonistas sejam assustadoramente próximas, a adaptação brasileira faz questão de revelar o quanto essas mesmas dicotomias são usadas a favor do discurso do homem dominador (enquanto que, a meu ver, e como dito antes, o original apresenta as dicotomias e desenvolve seus respectivos pontos de vista deixando entrever todas as suas possibilidades, sem táo claro posicionamento; a peça de Eurípides consiste muito mais em uma descrição de poderosas forças que se opóem do que na denúncia da usurpação sofrida por um dos dois pólos, e termina, como visto, por minar as próprias dicotomias que desenvolve, bem como suas mais imediatas identificaçóes). Joana contra Creonte: a fêmea selvagem contra o macho civilizado, sendo que selvagem aproxima-se perigosamente de pobre impotente, e civilizado de rico poderoso. A sabedoria bárbara da Medeia euripideana, que consiste, sobretudo, na manipulação dos phármaka, converte-se no feitiço da umbanda, pejorativamente chamada de macumba quando na boca de Creonte ou de sua filha Alma - lembre-se que, não à toa, a umbanda é a marca do negro pobre brasileiro, sempre semi-bárbaro e semi-selvagem aos olhos de seus outros. É, além disso, dentro do discurso de Creonte, esse simulacro de tirano, que encontramos a simbologia animal voltada para a delimitação de uma tipologia que tem como fito restringir o campo de ação de sua inimiga. Em poucas palavras, em Gota d'Água as contraposiçóes euripideanas são exploradas precisamente para serem denunciadas como instrumentos de dominação.

Nesse sentido, e correspondentemente, a lei, símbolo de civilização no original grego, se transmuta em símbolo do poder e da manipulação. Bárbaro e selvagem, portanto, passa a ser o povo como um todo, em contraposição à lei, sempre forjada pelo mais forte. Dizem as vizinhas de Joana: "Virgem, cultivai em mim o respeito às leis e ao apetite do mais forte. Joana rebelde

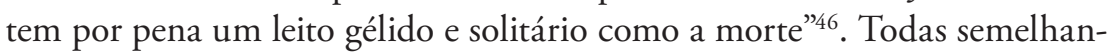

45 Um importante exemplo de como isso ocorre na peça é a cena em que Jasão e Alma falam sobre Medeia e sobre o fato de que ela "freqüenta terreiros". Cf. Buarque e Pontes 1975: 91.

46 Buarque e Pontes 1975: 138. 
tes a Joana em condiçóes e posição social, as vizinhas imploram para não incorrerem no mesmo erro dela - o orgulho excessivo, a altivez, a rebeldia, em parte responsáveis pela pena sofrida pela protagonista. Ora, é precisamente aqui que se entrevê uma outra simbologia animal jazendo sob a adaptação da peça grega, correndo por suas entrelinhas e contrapondo-se ao modo como até aqui ela fora desenvolvida. Trata-se, agora, do animal domesticado, não mais da rebelde selvageria de Joana. Essa imagem do bicho submisso aparece rapidamente na Apresentação, quando se fala do tratamento das classes subalternas como "rebanho de marginalizados" ${ }^{\text {" }}$. $\mathrm{O}$ rebanho, evidentemente, representa a massa controlada, dominada, mansa. Durante a peça propriamente dita, a imagem do animal doméstico aparece em uma única, mas a meu ver extremamente marcante, ocasião: uma briga de botequim entre os moradores do conjunto habitacional. Cacetão, vizinho apaixonado por Joana, provoca seus amigos: "Cacetấo: (Estalando os dedos como quem dá comida aos cachorros) Vem cá, vem, Lulu, toma uma linguiça, pára de latir, vai... Boca: Seu Amorim, esse cara quer o quê? Xulé: Não atiça, Cacetão... (Cacetão segue estalando os dedos) Sim... Assim... Gostou da linguiça? Amorim: Cacetão, porra... Cacetão: Vai fazer cara feia pro Creonte (Estala os dedos) Vem, Cotó, lambe..." ${ }^{\text {48 }}$. Aqui, a metáfora do animal mostra sua outra face: a do cáo que lambe as botas do patrão por uma simples migalha; que agradece pelas sobras; que bajula e leva em troca humilhação. Essa outra face, por sua vez, melhor ilumina a primeira: as duas simbologias animais - o doméstico e o selvagem - estão sobrepostas, e póem uma à outra em funcionamento: o cáo submisso e obediente ao dono, o rebanho bovino dirigido pelo pastor, por oposição ao animal revoltoso, insubmisso, ameaçador.

E é precisamente na sobreposição das metáforas animalescas que se ilumina a posição de Joana. Ou ainda: é por essa ótica que melhor se compreende a chave da sua resposta: "Joana: Pra não ser trapo nem lixo, nem sombra, objeto, nada, eu prefiro ser um bicho, ser esta besta danada. Me arrasto, berro, me xingo, me mordo, babo, me bato, me mato, mato e me vingo, me vingo, me mato e mato" ${ }^{\prime 49}$. Trocando em miúdos, Joana de alguma forma assevera: sou bicho para não ser gente submissa. Ser animal é o único meio possível; é só o que resta ao impotente para tornar-se visível, e à mulher para equiparar-se ao homem. É como se a sabedoria de Joana - que nesse sentido

\footnotetext{
47 Idem, xvi.

48 Buarque e Pontes 1975, 145.

49 Idem, 47.
} 
é absolutamente comparável à de Medeia no clássico euripideano - fosse a clara visão de que, pelos mesmos meios, não será possível chegar a lugar algum. Ela vislumbra, portanto, outros caminhos, métodos alternativos. Em certo sentido, Joana e Medeia afirmam que a mulher precisa usar a sua sabedoria de outros modos, apenas assim equiparando-se ao homem em potência destrutiva, ou até mesmo lhe ultrapassando ${ }^{50}$.

Ainda persistindo nessa trilha, é possível perceber, portanto, que Joana é o símbolo de um grupo. Não apenas do grupo das mulheres, mas, sobretudo, do grupo dos "subalternos". Nesse sentido, Joana é apenas o retrato e o resumo de uma coletividade sempre à beira do colapso, sempre prestes a transbordar com uma única e última gota d'água. Porém, destaca-se do grupo a que pertence e que simboliza justamente por entrar em colapso. Por escolher a rebeldia e a selvageria como resposta à humilhação, que não é a tendência mais freqüente do coletivo. Por um lado, Joana, ao contrário de Medeia, não é a desterrada, a sem pertencimento. Essa gota d'água não é só dela, é de todos. É isso, pelo menos, que ela responde a Jasão quando ele reclama de seu modo urgente: "Só que essa ansiedade que você diz não é coisa minha, não, é do infeliz do teu povo, ele sim, que vive aos trancos, pendurado na quina dos barrancos. Seu povo é que é urgente, força cega, coração aos pulos, ele carrega um vulcáo amarrado pelo umbigo. Ele entáo não tem tempo, nem amigo, nem futuro, que uma simples piada pode dar em risada ou punhalada" ${ }^{51}$. Se Medeia é a solitária, estrangeira bárbara entre gregos civilizados e semi-deusa entre humanos, o avesso do grupo, aparecendo sempre em "isolamento radical" 52 , ("Quanto a mim, só butim em solo bárbaro, sem urbe, rebaixada por Jasão, sem mãe, sem um parente..." 53 e também "Não te é familiar o exílio? (...) Desconheces o preço do vazio de amigos?"’4), Joana é igual a todos os outros. Ela encarna a situação limite que no fundo é a de muitos, e no mais das vezes. Náo obstante, ao contrário desses muitos, ela não se submete. Joana é solitária como Medeia

50 A grande diferença parece ser, como sugerido acima, que, no clássico, há conflito de pontos de vista, ambos fortes e sustentáveis. Em sua adaptação carioca, há clara tomada de posição a favor da besta fêmea, também como dito antes. Não irei aqui mencionar, por óbvias, as gritantes diferenças entre contextos históricos, que por si só já são capazes de justificar esse fato.

51 Buarque e Pontes 1975: 126.

52 Vieira 2010: 157. Como lembra o tradutor, Medeia não pode retornar à terra natal e aos seus, haja vistas as atrocidades que ali cometera por amor a Jasão.

53 Medeia 255.

54 Medeia 880 e 881. 
precisamente em sua selvagem rebeldia. Se todos estão prestes a explodir, Joana é a única que de fato explode, recuperando dessa forma a solidão da protagonista euripideana.

Surpreendentemente, é nesse ponto ínfimo, nessa mínima gota que provoca o colapso, que encontramos um último espantoso contato entre o clássico grego e a sua adaptação carioca. Pequeno, minúsculo, quase irrelevante e certamente imperceptível até para os adaptadores, esse ponto de contato encontra-se em uma breve metáfora, que poderia passar despercebida, mas que se torna eloqüente face ao cerne da releitura brasileira do tema de Eurípides. No mar, é absolutamente necessária uma espécie de válvula de escape; é preciso retirar a água acumulada na sentina, o porão das galés, antes que mais água se acrescente à anterior; da alma é preciso, do mesmo modo, desaguar o pesar. Tal imagem marítima - essa metáfora da alma-barco prestes a explodir caso náo seja esvaziada de males - aparece no verso 79 da Medeia grega, e é quase sempre ignorada pelos tradutores (agradeço, assim, a Trajano Vieira, cuja cuidadosa tradução não deixou o verbo antléo, que evoca as águas e o contexto marítimo, passar despercebido): "Quanto pesar, se o mal se acresce ao mal, sem que o anterior deságüe da sentina" 55 . Caso contrário, acrescenta Joana, a Medeia carioca, o último minúsculo pesar (já tragicamente prefigurado no samba de sucesso de seu ex-marido Jasão), "pode ser a gota d'água".

55 Eurípides, Medeia 79. 


\section{Bibliografia}

Buarque, C., Pontes, P. (1975), Gota d'Água. Rio de Janeiro: Civilização Brasileira.

Cairus, H. (2005), “Medeia e seus Contrários”, Revista de Letras 27: http://www.revistadeletras.ufc.br/

Cantarella, R. (1977), Euripide. Medea. Prefazione di Dario del Corno. Milano: Arnoldo Mondadori Editore.

Foley, H. (1989), “Medea's Divided Self”, Classical Antiquity 8. 1: 61-85.

Gagnebin, J-M. (1997), Sete Aulas sobre Linguagem, Memória e História. Rio de Janeiro: Imago.

Gondicas, M., Combe, P. J. (2012), Euripide. Médée. Paris : Les Belles Lettres.

Knox, B. (1977), "The Medea of Euripides in Greek tragedy”, Yale Classical Studies 25: 193-225.

Mueller, M. (2011), "The Language of Reciprocity in Euripides' Medea", American Journal of Philology 122. 4: 471-504.

Musurillo, H. (1966), “Euripides’ Medea: a reconsideration”, American Journal of Philology 87. 1: 52-74.

Reeve, M. D. (1922), “Euripides’ Medea 1021-1080”, Classical Quarterly 22. 1: 51-61.

Vieira, T. (2010), Eurípides. Medeia. Tradução, posfácio e notas. São Paulo: Editora 34. 


\title{
Ecos de Platão em Vergílio Ferreira \\ (Platonic echoes in Vergílio Ferreira)
}

\author{
Maria do Céu Fialho \\ Centro de Estudos Clássicos e Humanísticos da Universidade de Coimbra \\ (mcfialhofluc@gmail.com)
}


Página deixada propositadamente em branco 
Resumo - A peculiaridade da relação de Vergílio Ferreira com os Clássicos e da presença destes na sua obra consiste no modo como os envolve, numa síntese original, com pensadores contemporâneos, constituindo essa síntese como que um discurso em que se pensa e no qual constrói o mito dos seus narradores-pensadores. Estes procuram, no itinerário das suas memórias ficcionais, uma verdade sabida e 'esquecida', procuram encontrar aquele momento de revelação de si a si mesmos, a 'aparição' em que o absoluto do humano é fugazmente perceptível e a verdade da existência se ilumina. A tragicidade da consciência da limitação humana, reforçada pelo trágico grego das origens, é, assim, um dos motores para a transposição, pela memória, sobretudo pelos mitos da memória, como o mito da infância-origem, da facticidade, em busca dessa verdade a que o homem pertence e que lhe confere um halo de imortalidade. Em tal dinâmica percebe-se a presença inspiradora de Platão. Palavras-chave - Vergílio Ferreira, reescrita-síntese, Clássicos, Platâo, aparição, infância-mito.

Abstract - The peculiarity of Vergilio Ferreira's approach to the Classics and the Classics' presence in his work consists in the way how the author combines them, in an original synthesis, with modern thinkers. This synthesis builds a speech in which the author thinks himself and in which he creates the myth of his narrators-thinkers. Through the itinerary of their fictional memories they seek for a known and 'forgotten' truth; they seek for the moment of their self-revelation to themselves, the so-called 'aparição', in which the absolute dimension of human being is fleetingly perceptible and the truth of the existence comes to light. The tragic conscience of human limitation, reinforced by the original Greek tragedy, increases the transposition of facticity, achieved by the memory and its myths (as the myth of childhood), in order to attain the truth to which man belongs and from which man receives his light of immortality. Such dynamics make perceptible the inspiring presence of Plato.

KeY wORds - Vergílio Ferreira, synthetic rewriting, Classics, Plato, 'aparição', myth of childhood.

O Neoclassicismo winckelmanniano, que preside à génese da Arqueologia e da História de Arte, abre à Europa culta da primeira metade do séc. XVIII, uma nova forma de olhar a Grécia Antiga - olhar marcado pelo espanto e pela experiência estética da perfeição, da proporção, do esplendor da sua escultura e arquitectura, como filhas da luz mediterrânica. Esta explicaria toda uma cultura e oferecer-se-ia, em boa verdade, à experiência destes homens, como o grande mediador, intemporal, que propicia compreensão e abre caminho à identificação e à experiência de pertença.

$\mathrm{Na}$ segunda metade do século, e já na viragem para o século XIX, o idealismo hegeliano irá, determinantemente, olhar a Cultura Grega e Romana 
simultaneamente como um outro e como raiz do nosso modo de ser e pensar. Na sua Fenomenologia do Espírito, bem como nas Liçöes sobre Filosofia da História, Hegel reflecte sobre dimensóes das culturas antigas, cristalizadas sob forma estética, que determinaram a vivência social e os conflitos do homem ocidental. É bem conhecida a sua leitura do trágico como conflito inultrapassável entre direito natural e direito positivo, equacionado na Antígona de Sófocles, ou o reconhecimento, na vivência de estado, em Roma, do cerne do que há-de configurar a moderna noçẫo de "Estado". O filósofo determinou a leitura romântica da Antiguidade e os caminhos a que esta sua leitura serviu de pressuposto e de inspiração, já longe da leitura primeira, sob a forma de uma leitura utópica do passado - manifestação essa ainda comum a muitos e notáveis poetas dos nossos dias, bem como à chamada "Grécia do turista".

O século XX, sobretudo como consequência retardada da Segunda Guerra Mundial, abre, no Ocidente, brechas profundas na sua experiência de identidade(s) e de pertença matricial. O passado que se denega constitui uma das consequências do complexo pós-colonial e deixa o indivíduo e a colectividade expostos a uma crise de memória e de pertença, sob a forma de vergonha e denegação, muitas vezes traduzidas por um discurso de prevalência absoluta de um futuro, que apaga o passado, e a que falta, por isso mesmo, o sentido claro, já que o trajecto peca por ausência de um dos pontos de referência: o da origem de onde provimos.

A Hermenêutica Filosófica, a que Heidegger conferiu a dimensão de modernidade, e que conhece os seus progressos e elevando-se a alto expoente com Gadamer e Ricoeur, contrapóe-se com eficácia e lucidez a tais olvidos ou denegaçóes, fruto da 'vergonha': o fascínio pelas alteridades encontra um 'Outro' privilegiado, a compreender, a interpretar, que se apresenta revestido de um carácter peculiar e único - ele é a raiz do que somos, situa-se no âmago das nossas origens, ainda que as tenhamos esquecido, esquecendo quem somos. Compreender-nos passa, entâo, por compreender o que está na nossa génese civilizacional e nos determina e define.

É através dessa linguagem cultural que herdámos, no seio da qual aprendemos a exprimir-nos e a pensar o mundo, que aprendemos a compreender-nos. O círculo hermenêutico de abertura compreensiva a esse outro para nos compreendermos a nós, no que já Gadamer consagrou conceitualmente como "fusão horizôntica" - conceito retomado pela escola de Constança, com Jauss -, constitui uma necessidade para compreender o mundo e o ho-

1 Este oportuno conceito e definição é da autoria do arqueólogo Himmelmann 1976. 
mem, para nos compreendermos, perspectivando as verdadeiras dimensóes da memória cultural.

Ora uma vez quebrada essa inocência da "transmissão" inquestionável, ou a dimensão óbvia da "tradição", tem-se por consequência que a reescrita dos mitos greco-latinos deixa de ser, com frequência, um recurso de comunicação poética natural e não pensado, para passar a constituir, assim, um gesto consciente de afirmação identitária e de pertença a uma referência matricial, transmitida e enriquecida nessa transmissão apropriadora ${ }^{2}$.

Mais modernamente, a tal reescrita alia-se, com frequência, o reforço da consciência clara e teoricamente enquadrada do valor das opçóes estético-comunicativas tomadas, assumidas através da estratégica metadiscursiva no texto poético, pela reflexão sobre o papel da narrativa - mythos - no processo de reconhecimento do homem nela (o narrador) e no processo de compreensão do tempo humano aí cristalizado. A reescrita do mito adquire a dimensão de uma invocaçáo, por vezes, até, de uma provocaçáo, ou pode, de outra forma, assumir a natureza de um diálogo problematizante acerca do tempo, do homem e da sua história e natureza. E esta reescrita na ficção - como é o caso em Vergílio Ferreira - pode conviver com a reflexão teórico-filosófica sobre ela, por parte do autor, no contexto da sua produção ensaística.

O fenómeno de 'presentificação dos Clássicos', na escrita romanesca, pode, todavia, revestir-se de formas várias e originais, em função de intencionalidades específicas e correspondentemente originais.

$\mathrm{Na}$ escrita de Vergílio Ferreira essa presentificação constitui um gesto criador de quem os conhece por dentro, de quem os assimilou e reelaborou, através da sua própria formação de Classicista, do seu percurso académico de juventude, com os seus sonhos, com a necessidade dos seus próprios mitos, habitando uma cidade universitária carregada de tradição e dos mitos que sobre ela se construíram. Vergílio Ferreira viria a encontrar na síntese entre aqueles e estes uma das 'moradas' do seu imaginário, um espaço de reflexão de maturidade e um alfobre de linguagem de criação. Por dentro de Coimbra amadurece, na sua juventude académica, a reflexão filosófico-literária que enlaça, precisamente, Camóes e Platão ${ }^{3}$.

2 Estas reflexôes correspondem ao aprofundamento e expansão de reflexões feitas em Fialho 2012: 197-199.

3 Sobre o mito de Coimbra na obra do escritor, vide Fialho 2013: 939-948. 
A genialidade com que Vergílio Ferreira integra, muitas vezes, referências clássicas ou concebe os seus narradores entregues a reflexôes, animados por anseios que se decalcam em estruturas de pensamento filosófico de matriz grega, e reveste tais referências ou tais processos reflexivos com a linguagem de tipologias romanescas ou de problemática ou perspectivação filosóficas contemporâneas, faz com que não seja, frequentemente, óbvia, essa presença do Antigo. E é essa peculiaridade que a torna mais genuína, mais sentida por dentro, mais integrada no discurso e mais difícil de identificar, com extrema frequência. É essa peculiaridade que atesta, também, até que ponto o desafio da presença e da pertinência de pensar e pensar-se profunda e criativamente com os Clássicos tem no romancista-ensaísta uma resposta tão densa.

O Homem pensa-se em linguagem, o Homem consciente das raízes da sua historicidade pensa-se, conscientemente, na sua linguagem cultural, modela-a, nela opera sínteses e nexos, nela opera transposiçóes ficcionalizantes para se descobrir, se reinventar, se encontrar com o novo ou o insuspeitado de si mesmo e dos nexos que a vida nele tece, muitas das vezes, surpreendentes.

Entre o ensaísta e o autor do romance-ensaio, a escrita corresponde a essa linguagem de descoberta ou reinvenção - pela reflexáo directamente assumida ou mediada pelo mito da narrativa ficcional, em que o narrador percorre pela memória, algumas vezes apoiado na escrita, uma existência revisitada, em busca de um sentido unificador ${ }^{4}$. Assim, o ensaísta esclarece ${ }^{5}$ :

"... adianto a resposta ao "porque é que escrevo", dizendo simplesmente que escrevo porque é essa a minha forma de estar vivo...Assim estar vivo é realizarmo-nos por aquilo que mais fundo nos fala...».

Esta afirmação é recorrente e encontra paralelo na boca de narradores vergilianos, como Alberto Soares em Aparição $0^{6}$ :

«O que me arrasta ao longo destas noites, que, tal como esse outrora de que falo, se aquietam já em deserto, o que me exci-

4 A 'Stimmung', decorrente de uma situação peculiar, de limite, a partir da qual esse périplo de memória-narrativa se opera, e da qual recebe uma peculiar iluminação, foi objecto de estudo em obra referencial para os estudos vergilianos: Goulart 1990.

5 Espaço do Invisivel, 4, 17.

6 P. 193. 
ta a escrever é o desejo de me esclarecer na posse disto que conto, o desejo de perseguir o alarme que me violentou e ver-me através dele e vê-lo de novo em mim, revelá-lo na própria posse, que é recuperá-lo pela evidência da arte. Escrevo para ser, escrevo para segurar nas minhas máos inábeis o que fulgurou e morreu».

E, no entanto, a palavra é, simultaneamente, espaço de procura, de realização, mas, como marca da humanidade, prisão necessária, como as sente, ainda em Aparição, o narrador?:

«Estamos condenados a pensar com palavras, a sentir em palavras, se queremos, pelo menos, que os outros sintam connosco. Mas as palavras são pedras. Toda a manhã lutei não apenas com elas para me exprimir, mas ainda comigo mesmo para apanhar a minha evidência. A luz viva nas frestas da janela, o rumor da casa e da rua, a minha instalação nas coisas imediatas mineralizavam-me, embruteciam-me. Tinha o meu cérebro estável como uma pedra esquadrada, estava esquecido de tudo e no entanto sabia tudo».

Na perspectivação da arte como redenção do Homem reconhece-se a influência de Malraux, que exerceu no autor um particular fascínio durante uma fase da sua vida (meados dos anos sessenta), mas a dimensão do «escrever para ser» domina toda a produção vergiliana desdobrada na galeria de narradores-pensadores.

Que perseguem eles? Que expectativa de plenitude ontológica abre esse projecto de 'para ser', que envolve ensaio e ficção? O ensaísta reconhece a dupla dimensão dessa plenitude procurada: a "presença de mim a mim próprio» e o «acesso a uma verdade essencial... aquela verdade que está antes de todas as razóes e onde precisamente por isso as razóes se geram, como Platão e Aristóteles pensavam para a filosofia, que, antes de ser uma sistematização de ideias ou razóes, é apenas o puro «espanto», ou seja, "o choque emotivo que às mesmas ideias há-de movimentar." ${ }^{8}$

\footnotetext{
7 P. 44.

8 Espaço do Invisivel, 4, 17-18. “...evidência-fundadora, a tantas vezes já aludida aparição. Da evidência das evidências faz parte, no universo de Vergílio Ferreira, a consciência da sua inscrição no horizonte da morte", comenta Lourenço 1993: 121, para completar, em seguida (122-123): "A «solução" de Vergílio Ferreira tem duas faces....A nossa vida, enquanto apariçâo, na sua verdade profunda, não tem propriamente morte, é, no sentido próprio, imortal. Por outro lado, é esse irreal da morte, essa ameaça em que consiste funda-
} 
Por essa razão, autor empírico e narradores escrevem ou percorrem os itinerários de memória: para ser. E o narrador vergiliano fá-lo, no contexto de um mito criado pelo primeiro, em que o primeiro projecta e cristaliza, ficcionalmente, os itinerários da sua procura. Onde a verdade absoluta, primordial? Vergílio Ferreira chama à sua ficção componentes do moderno romance autobiográfico de memórias de infância, marcado, sobretudo em Nathalie Sarraute, por um meta-discurso intradiegético de interrogação sobre a facticidade do rememorado.

$\mathrm{Na}$ típica estrutura do romance vergiliano o narrador, a partir de uma situação-limite, percorre repetidamente os caminhos da memória para neles encontrar a 'sua' verdade, o sentido da sua humanidade, e sempre volta à situação narrativa.

Diz ainda, para si mesmo, Alberto Soares, em Aparição, a partir da sua casa de infância, na aldeia, rememorando momentos da sua existência como um estrangeiro, em Évora, em que se debatera nesse esforço agónico da memória. Recorde-se a citação de há pouco «Tinha o meu cérebro estável como uma pedra esquadrada, estava esquecido de tudo e no entanto sabia tudo. Para recuperar a minha evidência necessitava de um estado de graça»?.

Desse esquecimento do ser, ou do ser-se, é possível aos narradores despertar para uma súbita aparição (palavra recorrente na ficção do autor), mediante o «alarme» ou o «eco». E esse eco pode erguer-se de uma música concreta, entoada pelo coral dos trabalhadores no vale a que a casa de infância está sobranceira, em Para sempre, ou de dentro da igreja, em rituais perdidos para o narrador, cá fora, e que acendem na memória uma não-saudade que é carência - outro modo de ser saudade - de um tempo primordial ${ }^{10}$ :

«E era aí, na aparição da manhá, que os cânticos de Natal se me abriam luminosos, lavados na pureza de um início absoluto, inventados em inocência e em confiança perene... Não tenho saudades de mim, não tenho saudades de nada: amanhã é o dia de hoje. O que

mentalmente a sua presença ...que confere à nossa existência a sua seriedade, a sua grandeza e pouco importa que o sentimento delas seja expresso numa alegria desmedida ou numa amargura infinita. Lá onde somos quem somos, alegria e amargura são irmãs gémeas e proclamam por nós que é bem o excesso de nós que nos constitui e nos define”.

9 P. 44. Veja-se 'eco' como expressáo da incapacidade de encontrar caminho para a 'presença', convivendo com a "imagem de mediação que tenta abolir a Disjunção", constituída pelo canto e pela música, ora nascidos e identificados com a terra (o primeiro), ora vindos do longe, mais próximos do eco (Godinho 1985: 62 sqq.; 219 sqq.)

10 Aparição, 145. 
me seduz no passado não é o presente que foi - é o presente que não é nunca». Por seu turno, essa «voz das origens esclarece-se no mito que nos vive», como diz o narrador de Alegria Breve ${ }^{11}$, e nele se pressentem as marcas de uma alegria de plenitude procurada e que pertence «a um outrora absoluto, desde antes da infância, do eco que me transcende do passado ao futuro, me vibra com o som de uma harmonia que eu não seì ${ }^{12}$.

As memórias de infância, recuperadas por aquilo a que o narrador de Até ao Fim designa como uma "memória-ficção»" nesse itinerário pelos labirintos da existência, oferecem-se, assim, como campo privilegiado para a busca dessa centelha unificadora de sentido para a existência, mediante a recuperação de um tempo uno e coeso, de origens. Mas o narrador sabe que o que busca na infância não é o que na infância viveu - o passado não se recupera, «o passado que se evoca nunca existiu para ninguém», «o passado a que pudéssemos voltar com uma "máquina do tempo" seria a decepção do presente que foi e o imaginário nos transfigurou» como declara Vergílio Ferreira na cerimónia do seu doutoramento solene, na Universidade de Coimbra $^{14}$. A recuperação mitificante da cena do bolo pascal, em Signo Sinal, é eloquente ${ }^{15}$ :

«Havia um mistério de sagração antiquíssimo, o sinal visível dele - o bolo intacto perfeito. Isolado, a meio da mesa, puro. ... $\quad \ldots \quad \ldots$ Acumulara-se nele a dádiva de geraçôes, requintada, apurava-se a essencialidade dos séculos. O bolo. Íntegro, selado na sua nudez. Nítido preciso. Único...A sala um pouco obscura na tarde. Estamos todos imóveis. A criada tem um braço no ar, imobilizada no seu gesto. $\mathrm{O}$ tempo fixo».

Este instante de eternidade e de sagrado, captados no transitório, pertencem a uma infância eterna e nunca vivida, como o traduz a belíssima série de apóstrofes do mesmo narrador ${ }^{16}$ :

\footnotetext{
11 P. 156.

12 Aparição, 129. Sobre a infância mitificada, vide Fialho 1997: 203-217.

13 P. 118.

14 Espaço do Invisivel, 5, 127.

15 P. 147.

16 P. 46.
} 
«Ó infância do nunca, substância íntima do meu ser...ó infância da legenda, morada do meu ser...luz suave de outrora».

Estamos, pois, perante um aceno de uma arche, a que o homem se sente referenciado, e em que prende, no mito da sua própria existência, por um instante célere e fugidio, o que a transcende e constitui a sua própria verdade. O tempo fixo representa a transposição do acontecimento saído da transitoriedade para uma transtemporalidade a que se referencia o acontecer da existência. O presente é marcado por uma nostalgia de raízes de carácter mais profundo - a nostalgia das referências ontológicas fundamentais, buscadas pelo narrador vergiliano.

À dimensão daquilo que transborda para lá dos mitos da memória ficcional, da infância, e que aquela procura captar, dá Vergílio Ferreira a designação de transreal, onde o absoluto e a verdade residem, e que o homem esquece, ou para que desperta pelo eco de algo já sabido originalmente, mas oculto à consciência ${ }^{17}$ :

«A aparição nada acrescenta ao que nos «aparece» a não ser a visão flagrante do que estava oculto no que já sabíamos talvez. Mas esse acréscimo remete o saber para uma dimensáo nova como decerto para o místico o êxtase da revelação. Há o real, verificável, transacionável. E há o transreal desse real, que é ainda esse real, mas no inesperado do seu mistério de ser».

Como foi referido no início deste trabalho, a peculiaridade do diálogo vergiliano com os Clássicos, com que aprendeu a pensar e que, por isso mesmo, traz para o âmago da sua escrita, consiste em imbricá-los, numa síntese subtil, com paradigmas literários contemporâneos ou com perspectivas filosóficas contemporâneas. Atrevemo-nos a apontar uma inspiração platónica e o recurso a momentos do pensamento e da linguagem de Platão nessa referência 'esquecida' do homem ao absoluto, à eternidade, despertada pelo eco, acordada na memória por um sinal, que eventualmente propiciam a visão súbita de uma verdade que logo persiste, como lembrança, a instigar a procura do homem - do artista escritor, nos mitos que cria.

O segundo dos grandes mitos constitui o da juventude, aureolada pelo imaginário de Coimbra, incandescente de interrogaçôes e de paixão. Em Até ao Fim e Na Tua Face, a cidade da sua juventude universitária coinci-

17 Pensar 1992: 14. 
de com o mito da mulher amada, incorpórea, fugidia, omnipresente, na música que ecoa da guitarra fremente do narrador e enche todo o espaço como uma súplica. $\mathrm{O}$ seu nome vem do imaginário literário da tradição ocidental. É Oriana, em Na Tua Face, e Bárbara, em Até ao Fim. Bárbara acompanhará sempre a memória de Coimbra, potenciando todos os condimentos da imaginação poética que enquadram a balada e o fado e lhe compóem o texto, para os converter em expressão de algo mais profundo e constante na narrativa vergiliana: essa procura pelos labirintos da existência vivida e rememorada, essa vigília atenta aos sinais de uma aparição-chave, congregadora de sentidos, que revele o mistério de ser-se homem e dê resposta à sede de absoluto. Vigília em que sáo percorridos, incessantemente, os mesmos caminhos tornados outros. Por isso, na rememoração, se descai, progressivamente, do emprego do imperfeito para o de um presente intemporal, aorístico:

«Era uma noite de Maio já quente e doce e cheia do perfume do seu nome, nós subíamos para a rua de S. Joáo, mas ao Arco do Bispo virámos para o Largo da Feira. Estavam perto os exames. Bárbara estudava com uma colega, às vezes dormia lá em casa para um estudo pela noite. Sentámo-nos na escadaria da Sé e todo o espaço deserto e brevemente iluminado ressoa-me à memória da nossa música dolente. $\mathrm{E}$ ao primeiro acorde da guitarra toda a noite oscilou. A noite, o espaço silencioso do largo. Havia neles uma guitarra oculta, os meus dedos desferiram as suas cordas. Plácida melodia ouço nela uma notícia que vem do lado de lá da memória, desde o ininteligível que não ouso decifrar. A toda a roda do largo as casas adormeciam. Sabia que a da colega de Bárbara era uma das primeiras, bastante para cá da escola primária, mas náo sabia qual para a balada lhe bater à vidraça e ela a iluminar. Porque era o sinal de que estava a ouvir como estava desde sempre estabelecido. Eu tocava e ia olhando, a ver se uma janela se acendia, mas tudo se petrificava na noite e no largo náo passava ninguém. $\mathrm{O}$ céu era límpido de estrelas, Deus devia estar a ouvir-nos. Tocava com veemência uma balada crispada na guitarra e pensava sem pensar ela ouve-me, vai acender a janela, as estrelas do céu estremecem, no fundo do seu sono ela escuta. Sentia a vibração no espaço deserto do largo, era necessário que ela ouvisse a minha oração. Como num templo, a prece não é o que se diz mas a emoçấo do dizer, o frémito que a intensifica como o choro de quem pede. Ouvir-me. Dizer estou a ouvir no fundo do meu ser. Irei talvez ter contigo, caminharemos os dois 
de estrela em estrela até esgotarmos o céu. E provavelmente contra o tempo e a morte. Ouço a balada no eterno e eu estou lá à tua espera».

Por fim, Bárbara desprender-se-á dessa memória para desaparecer, caminhando, na bruma do mar, no desfecho do romance. O narrador ficará preso à cruel deformidade de um quotidiano que o desperta do sonho e que o prende, enquanto aspira por Bárbara. O filho deficiente que esta lhe abandona nas máos é o peso desse quotidiano, em que o homem se sente e se contempla deformado, disforme, em relação ao que o arrebatou para a centelha de um absoluto que lhe acalentou os sonhos de juventude.

Ao abandonar o narrador e o filho que lhe deixa, para se soltar e se dissolver na bruma marinha, esta Bárbara desaparece no mar, como a homóloga camoniana; no entanto, Vergílio Ferreira inverte o sentido do percurso das suas personagens: Bárbara dilui-se, como ícone de um sonho de juventude, da própria vitalidade do narrador; é este, verdadeiramente, quem naufraga em terra, irredutivelmente envelhecido, numa existência sem horizontes.

Entre Platão e um neoplatonismo de cariz literário, na mulher ideal petrarquista de recepção camoniana, tece o artista a teia expressiva em que a memória de juventude é aparada pelo seu transreal, como o escritor afirmou no seu doutoramento solene:

«O passado a que pudéssemos voltar com uma «máquina do tempo» seria a decepçáo do presente que foi e o imaginário nos transfigurou. Ora é esse imaginário que me perdura da Coimbra que foi minha. Não tendo existido, configura o grande mito que me existe da minha juventude $[. .$.$] é esse mito que se me desdobra como diadema do mais.$ O passado que se evoca nunca existiu para ninguém. Mas só o que não existe é que é bastante para o excesso do homem. Assim, o real da minha juventude é o transreal do seu encantamento e da eternidade que lá mora, como nos meus livros pude registar».

Situando-se Vergílio Ferreira na esteira de um existencialismo humanista que afirma marcado por Heidegger - e onde Eduardo Lourenço identifica ecos de "uma antiga sabedoria estóica, de tão fundas raízes ibéricas"18 - essa verdade que persegue, e que é fonte do desassossego do homem que se sente, simultaneamente, animado pela centelha de absoluto e ferido de morte pela sua consciência de finitude, reside no âmago do próprio homem,

\footnotetext{
18 Lourenço 1993: 123.
} 
na sua existência, em que procura decantar a sua própria essência, livre do «lixo das circunstâncias», por isso a reiventa, consciente de que só mediada pelo mito a poderá tocar. As referências, ou tópicos da ontologia metafísica platónica são transportados para o centro do próprio agir humano. Trata-se de um genial paradoxo que ao artista criador é permitido - e que nós classificaríamos de impensável. Mas responde o ensaísta ${ }^{19}$ :

"O impensável é o que faz que o pensamento pense, identificando-se com ele como a pele com o corpo - porque ela é esse corpo e está fora dele como limite», após ter afirmado ${ }^{20}$ : «Um filósofo não reflecte sobre a «diferença» entre filósofos, porque fazê-lo seria afirmar a precariedade e sem-razão da filosofia que é sua».

Vergílio Ferreira vai mais longe, conciliando, no seu trato familiar e inspirador com os Gregos, duas linguagens, na procura de compreensão de um realidade - a do homem, portador de absoluto que adivinha e de ser para a morte, preso à sua própria historicidade - a de inspiração platónica e a dos trágicos:

«Como o Prometeu esquiliano, seria bom pensarmos que nos importa esgotar o destino que nos coube $»^{21}$.

Saber desse destino é saber da verdade que anima o homem, palavra-síntese, palavra perdida, reinventada, para nela se tocar o que para além dela transborda ${ }^{22}$. Assim, os Gregos em particular propiciaram, em Vergílio Ferreira, essa fonte inspiradora para pensar com eles, em ensaio ou mediado pelo mito, essa realidade dolorosa e fascinante de ser-se humano, alfobre de eternas perguntas que fazem transbordar as fronteiras entre filosofias e entre filosofia e arte, nascidas do mesmo espanto original ${ }^{23}$.

\footnotetext{
19 Pensar, 16.

20 Pensar, 11.

21 Ibid. 127.

22 Vide Fonseca 1992: 33.

23 Gavilanes Laso 1989: 82-88 e, particularmente, em p. 88, sublinha a estreita ligação entre filosofia e arte (metafísica e poética) em Vergílio Ferreira, a que a vivência-reflexão da tragédia grega dá voz: "Náo por capricho, Vergílio Ferreira escolhe como epígrafe da sua obra mais grandiosa de exaltaçáo humana, Alegria Breve, o primeiro coro de Antígona, de Sófocles..."
} 


\section{Maria do Céu Fialho}

\section{Bibliografia}

Ferreira, V. (51991), Alegria Breve. Lisboa: Bertrand.

- ( $\left.{ }^{30} 1996\right)$, Aparição. Lisboa: Bertrand.

- (1987), Até ao Fim. Lisboa: Bertrand.

- ( $\left.{ }^{2} 1995\right)$, Espaço do Invisivel 4. Lisboa: Bertrand.

- (1998), Espaço do Invisivel 5. Lisboa: Bertrand.

- (1993), Na Tua Face. Lisboa: Bertrand.

- ( $\left.{ }^{3} 1994\right)$, Para Sempre. Lisboa: Bertrand.

- ( $\left.{ }^{4} 1992\right)$, Pensar. Lisboa: Bertrand.

- ('1990), Signo Sinal. Lisboa: Bertrand.

Fialho, M. C. (1997), "A infância-mito em Vergílio Ferreira ou a nostalgia da arche”, Confluências 15: 203-217.

Fialho, M. C. (2012), "Vergílio Ferreira e a Antiguidade Clássica”, in Pimentel, C., Morão, P. (eds.), A literatura clássica ou os clássicos na literatura. Lisboa, Campo da Comunicação: 197-206.

Fialho, M. C. (2013), "Coimbra. O mito da juventude no imaginário de Vergílio Ferreira”, in Pimentel, M. C., Farmhouse Alberto, P. (eds.), Vir bonus peritissimus aeque. Estudos de homenagem a Arnaldo Espírito Santo. Lisboa, Centro de Estudos Clássicos: 939-948.

Fonseca, F. I. (1992), Vergílio Ferreira: a celebração da palavra. Coimbra: Livraria Almedina.

Gavilanes Laso, J. L. (1989), Vergílio Ferreira. Espaço simbólico e metafísico. Lisboa: Universidade Católica Portuguesa.

Godinho, H. (1985), O universo imaginário de Vergílio Ferreira. Lisboa: INIC.

Goulart, R. M. (1990), Romance lírico. O percurso de Vergílio Ferreira. Lisboa: Bertrand.

Himmelmann, N. (1976), Die utopische Vergangenheit. Berlin: Mann.

E. Lourenço (1994), O canto do signo. Existência e literatura. Lisboa, Editorial Presença: 81135. 


\section{Imaginário clássico na poesia de António Arnaut \\ (Classical imaginary in the poetry of António Arnaut)}

Delfim F. Leão

Centro de Estudos Clássicos e Humanísticos da Universidade de Coimbra (leo@fl.uc.pt) 
Página deixada propositadamente em branco 
Resumo: O estudo analisa a forma como o imaginário da Cultura Clássica é usado e reescrito na poesia de António Arnaut, através de uma rede fina de alusôes discretas a alguns mitos e figuras, com especial destaque para os que têm forte ressonância iniciática, como o culto dionisíaco, os Mistérios de Elêusis e a figura de Orfeu. Palavras-chave: António Arnaut, reescrita do mito, Diónisos, Mistérios de Elêusis, Orfeu.

Aвstract: The study analyzes the way classical culture is used and rewritten in the poetry of António Arnaut, through a subtle net of discrete allusions to some myths and figures, with special emphasis on those with a strong initiatory resonance, like the cult of Dionysus, the Eleusinian Mysteries and Orpheus.

KeY-words: António Arnaut, rewriting myth, Dionysus, Eleusinian Mysteries, Orpheus.

\section{VIAGEM}

Para que no alarme dos sinos um pouco da Grécia repique. Natália Correia

Não me encontrei em Roma nem Atenas

não vi sombra de mim em Alexandria

nem, sequer, no rosto corroído da esfinge

ou na cripta da pirâmide de Keops

onde o silêncio pungia as palavras

com que Osíris despertava o sono do Nilo.

Procurei-me ainda em Tebas e Babilónia

banhei-me no sagrado rio Eufrates

mas só vi a ausência do que fui

na sonolenta saudade da corrente

como quem levanta ao céu seus olhos de água.

Passei por Jerusalém e pareceu-me ver

por entre as acácias floridas

junto das ruínas vivas do Templo de Salomão

um aceno do que sou, talvez a raiz

do pensamento alado ocidental.

Entretanto, mataram Aquiles

e o monte Parnaso

é agora um valhacouto de banqueiros. 
O poema que inaugura esta reflexão faz parte do último livro de poesia de António Arnaut ${ }^{1}$ e sintetiza, de forma muito clara, algumas das marcas mais características do universo poético recriado pelo autor e que será vantajoso evocar brevemente na antecâmara deste estudo. Antes de mais, a consciência de que o «alado pensamento ocidental» resulta da confluência de múltiplos influxos civilizacionais, onde a antiguidade clássica (representada por Roma e Atenas) ocupa um lugar de destaque, bem como outros espaços que dialogam naturalmente com esta mesma cultura matriz, como sucede com o Egito, a antiga Babilónia e Jerusalém. Depois, a afirmação discreta de que esses mesmos espaços formam igualmente o berço de um universo de valores fundacionais que dão corpo a um ideário de inspiração maçónica que o autor publicamente assume e que desponta em alusóes esparsas a referentes como a «cripta da pirâmide de Keops» ou as «ruínas vivas do Templo de Salomão». Por último, as marcas de uma poesia civicamente empenhada, que lança um grito de protesto perante o avanço aparentemente inelutável da força destruidora que aniquila os baluartes simbólicos de valores genuínos («mataram Aquiles»), para em lugar deles acoitar interesses mesquinhos («e o monte Parnaso / é agora um valhacouto de banqueiros») - numa alusão clara à atual crise financeira que tem castigado a Europa, em particular os países que foram berço das grandes civilizaçóes que moldaram a identidade ocidental.

Com efeito, António Arnaut, além de ser poeta, é também um estadista bem conhecido, ligado à fundaçáa do Partido Socialista português e à criação do Serviço Nacional de Saúde, ${ }^{2}$ assim se inscrevendo numa galeria notável de homens de ação, cujo perfil se pode fazer recuar ao famoso paradigma do ateniense Sólon. De resto, partilha com o antigo legislador ateniense um tipo de expressão literária profundamente marcada pelo empenho nas causas da comunidade, fazendo do seu autor um 'animal político' no verdadeiro sentido que a expressão assume em Aristóteles (Política, 1253a), quando sustenta que "por natureza (physis) o homem é um animal político (politikon zoon)». Ou para dizer de outra forma, que o ser humano se realiza em toda a plenitude através da identificação com a vida numa comunidade,

\footnotetext{
1 Arnaut 2013: 76. Este poema encontrava-se ainda inédito na altura em que este estudo foi apresentado, pelo que agradeço ao autor a gentileza de mo haver facultado antes da publicação. Este livro tem outros poemas que abordam também a Antiguidade clássica (como a composição "Sócrates", p. 54), mas que não foram objeto já de uma análise sistemática.

2 Por certo a sua obra mais emblemática e de momento sob ameaça, na sequência do plano de resgate financeiro assinado com a chamada "Troika" - e que o tem levado a uma redobrada intervenção cívica no debate político da atualidade.
} 
com as suas leis, prioridades e preocupaçóes sociais. ${ }^{3}$ De facto, a poesia de António Arnaut é marcada por um profundo sentimento de confiança na capacidade psicagógica da arte poética, ou seja na sua aptidão para ser 'condutora de almas', função essa que se traduz, não raras vezes, num atento empenho social, que reforça o papel do poeta enquanto intérprete e guia do seu tempo, e ainda enquanto agente ativo de progresso. ${ }^{4}$

Não será, porém, esse aspeto estruturante da poesia de A. Arnaut que se pretende agora analisar, mas antes a insistente presença do imaginário clássico em dois dos livros de poesia que o autor editou conjuntamente com o título de Miniaturais - Outros Sinais. ${ }^{5}$ Ao percorrer este conjunto de poemas em busca de marcas da cultura clássica, o leitor pode seguir dois caminhos diferentes. O primeiro, e mais rápido, consiste em identificar as indicaçóes que o autor fornece de forma clara, nas alturas em que menciona figuras como Orfeu (II.20) ou Tântalo (II.31). Referências desse tipo concentram-se, essencialmente, em Outros Sinais. A segunda via depende sobretudo do género de formaçáo e da sensibilidade de quem lê e, por essa razão, está aberta a maiores oscilaçóes no grau de entendimento. Ao longo deste estudo, serão privilegiadas as composiçóes em que estes dois tipos de memórias clássicas se conjugam.

Contudo, antes de se avançar nesse campo, será curioso notar que logo o primeiro poema de Miniaturais, que constitui uma espécie de afirmação do credo poético do autor, parece haurir de uma profunda tradição clássica, entendida, uma vez mais, como herança cultural comum:

Assim te quero, poesia:

descoberta, canto e profecia.

3 Entre outras figuras que se destacam nesta tribuna de políticos e escritores, pode evocar-se, por exemplo, o estadista senegalês Léopold Sédar Senghor, conhecido como poeta da Negritude e falecido em finais de 2001; ou então Manuel Alegre, cuja produção poética sublinha, com frequência, o mesmo empenho cívico do político e parlamentar.

4 Sobre esta faceta da poesia de A. Arnaut, vide Leão 2008: esp. 79 sqq., estudo que incidiu sobre a antologia que celebra os cinquenta anos de produçấo poética do autor, Arnaut 2004.

5 Arnaut 1987. Uma vez que o autor optou por dar título apenas ao último dos poemas (“Índice”), os passos em análise serão referidos pela simples indicação do número segundo o qual as composiçóes foram ordenadas. Para evitar a repetição constante do nome do livro em questấo, o número do poema será precedido de I, quando o exemplo é retirado de Miniaturais, e de II, no caso de pertencer a Outros Sinais. Assim, I.1 indica o primeiro poema de Miniaturais; II.5, o quinto de Outros Sinais. 
A associação da música e da poesia (implicada pelo "canto»" ${ }^{6}$ é uma característica do lirismo. De resto e como é bem conhecido, a designação de poesia lírica foi aplicada apenas pelos alexandrinos, já que os clássicos a designavam por poesia mélica, termo que tem a mesma raiz que 'melodia'. De qualquer forma, ambas as designaçóes salientam a ligação com a música. Por outro lado, a poesia enquanto «descoberta» de uma verdade que é necessário transmitir (facto que coloca o poeta na qualidade de um ser inspirado e daí que se possa falar de poesia como "profecia»), encontra o primeiro eco no didatismo de Hesíodo, expresso na fala das Musas, no momento em que estas o dotavam do saber poético. Nessa declaração se distingue entre a função recreativa da poesia (dizer falsidades com a aparência de verdade) e a sua função didáctica e esclarecedora (proclamar a verdade): ${ }^{7}$

Pastores que habitais os campos, triste vergonha, que só tendes [estômago! Nós sabemos dizer muitas falsidades, que se parecem com a verdade; mas também, quando queremos, proclamamos verdades.

Já no campo das reminiscências clássicas difusas, é possível detetar em A. Arnaut um aproveitamento quase constante das doutrinas de um dos filósofos pré-socráticos que maior fortuna conheceu: Empédocles de Agrigento. Nos poemas em consideração não há qualquer referência direta a Empédocles e de resto náo seria de estranhar se o autor afirmasse náo ter pensado no filósofo de Agrigento ao escrever estes versos, mas isso não

6 Notar que «canto» acaba por exprimir o valor frequentativo de cano, pelo que o seu significado original será não apenas o ato de cantar, mas sim de o fazer repetidamente, o que poderá ser uma afirmação discreta da perenidade da poesia e da necessidade da (re) leitura, aspeto que está claramente exposto no último poema, o qual será tratado mais adiante.

7 Teogonia, 26-28. Neste caso, como em outras citaçóes de autores gregos, adotaremos a versão portuguesa de Rocha Pereira 2009. O passo encontra-se traduzido na p. 107. Alguns fragmentos da poesia de A. Arnaut buscam claramente o efeito plástico/estético da escrita, como acontece com II.25, vv. 1 e 3: «Âncora de ouro. Ancoradouros, / Amar o mar é marear». No entanto, o seu verbo é, a mais das vezes, espaço de enérgica intervenção; e.g. I.2: «Ousar a palavra: / o poema não é o que se escreve, / mas o que nele se atreve.» Em I.7, temos um exemplo da hábil conjunção de ambos os princípios: «Adverso é o verso que náo rima / com o fogo da emoçáo que o amotina.» $\mathrm{O}$ desafio latente nestas palavras encontra eco na utilização da figura de rebeldes da mitologia, como Prometeu, num poema que analisaremos adiante. 
impede que ele seja o referente implícito, justificado pelas próprias circunstâncias peculiares que rodeiam a existência de Empédocles. ${ }^{8}$

O surgimento da prosa entre os Gregos tem o curioso particular de servir de suporte à expressão do pensamento filosófico e científico, seja talvez por a prosa ser a linguagem da razáo, seja por ser o meio de comunicação usual entre os homens. Mesmo assim, houve ainda filósofos que se exprimiram em verso, como Xenófanes (rapsodo profissional), Parménides e Empédocles. Estes dois últimos apresentam-se como iluminados pelos deuses e encarregados da tarefa de elucidar os homens na demanda da verdade. E, em relação ao pensamento de Empédocles, surpreende a aparente facilidade com que podem ser defendidas interpretaçôes tâo irreconciliáveis, como ver nele o representante de «um novo tipo sintetizador da personalidade filosófica» ou, pelo contrário, a personalidade muito antiga do «xamã que combina as funçóes ainda indiferenciadas do mágico e do naturalista, do poeta e do filósofo, do pregador, do curandeiro e do conselheiro público». ${ }^{9} \mathrm{Na}$ verdade, Empédocles acaba por ser ambas as coisas. Apesar de constituírem apenas uma parcela reduzida daquilo que escreveu, os fragmentos das suas obras são os mais extensos entre os filósofos pré-socráticos e fornecem, por conseguinte, uma boa fonte para a interpretação do seu pensamento. Esses fragmentos provêm de dois poemas, intitulados Sobre a natureza e Purificaçóes; no primeiro tem-se visto a criação de um cientista; no segundo a de um visionário. ${ }^{10}$

A personalidade de Empédocles (que viveu no séc. V a.C.) fez as delícias de histórias biográficas apócrifas, sobretudo as circunstâncias da sua morte, que o apresentam a precipitar-se na cratera do Etna. ${ }^{11}$ Tinha também reputaçáo de ser um fervoroso democrata, orador brilhante e curandeiro, facto que encontra eco nos seus poemas e pode estar na origem da anedota de que ele terá ressuscitado uma mulher que deixara de respirar. ${ }^{12}$ No entanto, não são estes aspetos que agora interessam, mas antes recordar rapidamente a

8 Para uma abordagem sucinta do pensamento deste filósofo pré-socrático, vide Dodds 1988: cap. V; Rocha Pereira 2012: 251-252, 262-263, 278-280; Kirk, Raven \& Schofield 1994: cap. X.

9 Opiniōes de Jaeger e de Dodds, respectivamente, apud Dodds 1988: 161.

10 Expressões de Rocha Pereira 2012: 278. Mesmo assim, esta distinção está longe de ser totalmente segura, já que há vários fragmentos de atribuição incerta. Cf. ainda Kirk, Raven \& Schofield 1994: 295-297.

11 Diógenes Laércio, 8.67-72; DK 31 A 1.

12 Diógenes Laércio 8.60-61; DK 31 a 1. Vide Kirk, Raven \& Schofield 1994: 294-295. 
essência das suas visóes cosmológicas. ${ }^{13}$ Será, por isso, vantajoso transcrever um dos fragmentos em que o filósofo as expõe: $:^{14}$
Todos estes elementos estão em harmonia,
o Sol, a Terra, o Céu e o Mar, - nas suas partes, que são lançadas bem longe em coisas mortais.
E assim todas as coisas mais próprias para se misturarem se buscam umas às outras e harmonizam em Afrodite. Mas sáo hostis as coisas que mais diferem umas das outras, em origem e mistura e nas formas nelas calculadas, não habituadas a unirem-se, e com muita relutância, por sugestấo da Discórdia, que causou a sua formação.

É a famosa e bem conhecida doutrina dos quatro elementos (terra, água, fogo e ar) e dois princípios (Amor e Discórdia) que ora os unem ora desunem e, como resultado dessas combinaçóes, dáo origem a tudo quanto existe. Como é do conhecimento geral, esta teoria teve uma larga aceitação e só foi posta de lado no séc. XVIII, por Lavoisier. Ao longo de mais de vinte séculos teve múltiplos tratamentos e representaçóes, sobretudo na arte. Ainda assim, trata-se de uma doutrina de tal forma difundida e enraizada no pensar comum que, mesmo depois de ter sido posta de lado em termos científicos, continuou a integrar, conscientemente ou não, o património cultural do ocidente. Pelo mesmo motivo, é um princípio altamente operativo na poesia de A. Arnaut, como se pode facilmente demonstrar através da evocação de alguns dos seus versos.

Conforme atrás se dizia, a teoria dos quatro elementos de Empédocles não aparece neste poeta expressa de forma sistemática, mas antes diluída na simbologia recorrente. Por essa razão, será necessário ter em conta os signos que pertencem ao mesmo campo semântico de cada um desses elementos. Assim, para ilustrar com alguns exemplos, ao signo da água ligam-se termos como "chuva", "mar", "onda", "lágrimas"; ao do ar, sobretudo o "vento", com um vasto leque de aplicaçôes; ao do fogo: "chama”, "sol”, "calor", "luz"; ao da terra: "semente", "seara”, "chão", "pão". Quanto aos princípios

13 Entre outros contributos importantes, são atribuídas a Empédocles a descoberta da respiração cutânea, a observação de que a luz se propaga no espaço (gastando tempo para o fazer) e a verificação experimental de que o ar é um corpo. Remissão para os testemunhos antigos e estudos sobre a matéria em Rocha Pereira 2012: 279.

14 Frg. 22 Diels-Kranz, em tradução de Rocha Pereira 2009: 243. 
que fomentam a sua união, há signos positivos, entre os quais se destacam termos como "amor", "liberdade", "justiça", "poesia"; do lado da desunião, alinham a "morte" e o "tempo" e, implicitamente, o estado de ausência dos signos positivos fomentadores da ordem. Entendendo desta forma a visão cosmológica de Empédocles, raros são os poemas de A. Arnaut que não ecoam, de alguma forma, essa herança. ${ }^{15}$ Bastará no entanto, a título ilustrativo, evocar uma das composições, convidando o leitor a verificar depois, por si mesmo, a justeza da aplicação desses princípios noutros carmes. Recorde-se, por conseguinte, um dos poemas onde o esquema foi adaptado de maneira mais interessante (II.27):

\author{
Terra! \\ Quando digo terra, digo vento \\ batalhas e poemas - os socalcos \\ onde o sol é raiz do pensamento. \\ Quando digo terra, digo céu \\ labaredas, estrelas — os sinais \\ que o tempo promete a Prometeu. \\ Quando digo terra, digo rios \\ searas, oceanos - os caminhos \\ ancorados na proa dos navios.
}

Digo terra, companheiro, e a voz canta a esperança que nos mastros se levanta.

O elemento de partida é a «terra»; na primeira estrofe, combina-se com o «vento» e com o «sol»; dessa conjunção resulta o "pensamento», impulso criativo relacionado com as «batalhas» travadas no interior da mente, expressas através dos "poemas», que tanto podem ser versos como açóes (se for tida em conta a relação etimológica com poiein 'fazer'). Na segunda estrofe, a "terra» alia-se essencialmente ao elemento ígneo, representado pelas «labaredas» e «estrelas». Tal opção não acontece por acaso, já que o autor alinha também uma referência a Prometeu que, por roubar o fogo aos deu-

15 Cf. I.4; I.5; 1.6; I.7; 1.8; I.10; I.11; I.12; I.13; I.14; I.15; I.18; I.21; I.23; I.30; I.34; I.37; I.38; I.39; I.44; I.45; I.48; I.49; I.51: I.52; I.58; I.61; I.62; II.4; II.5; II.8; II.9; II.16; II.21; II.23; II.24; II.25; II.28; II.31; II.34; II.35; II.38; II.41; II.42. 
ses e o dar aos homens, acabou por ser agrilhoado. ${ }^{16}$ Para o Titã, esses são os sinais da desejada libertação, "que o tempo promete», mas vai adiando. Como tantas vezes acontece na poesia de A. Arnaut, o "tempo» assume uma função negativa, neste caso a de separar os elementos da terra e do fogo. Prometeu era o deus ferreiro, mas, juntamente com Atena, assistia aos trabalhos de olaria. O barro identifica-se com a terra e, se a ele se náo juntar o fogo, não poderá dar origem às peças de cerâmica, que, enquanto 'obra de arte', também podem ser consideradas um 'poema'. Na terceira estrofe, a «terra» alia-se ao último elemento, a água, representada pelos «rios» e «oceanos». Esta associação é naturalmente fértil, como indica a presença das «searas». No entanto, esse produto não chega para satisfazer o poeta. A segunda parte da estrofe alimenta, já, o desejo de conhecimento, através do percurso de novos "caminhos», que os «navios» permitiriam realizar. Contudo, esses projetos continuam «ancorados na proa», sem ultrapassar ainda o limiar da promessa. Na última estrofe, aparece o elemento catalisador da uniáo entre a terra e a viagem através do meio líquido: «a esperança que nos mastros se levanta», como se fora uma vela. As velas necessitam, obviamente, de ser enfunadas pelo vento, pelo que o fim da composição retoma o elemento 'ar' da primeira estrofe, descrevendo assim um ciclo que sempre se renova. ${ }^{17}$

A ideia de construir ciclos sucessivos de esforço e trabalho, própria da existência humana, está expressa noutro poema, em conexão com o aproveitamento da figura de um dos supliciados divinos (II.40):

\author{
Quando chegares ao fim, volta ao princípio, \\ recomeça a obra inacabada. \\ Todo o fim é início \\ de nova caminhada. \\ Espiral de vida, humana condição \\ de ser o absoluto e o relativo. \\ Sísifo a procurar o páo \\ de que só a fome eterna tem motivo.
}

16 A. Arnaut faz uso de um falso jogo etimológico entre «promete» e «Prometeu». Na verdade, o nome do Titã está relacionado com o verbo promanthanein ('saber de antemão') e daí que signifique algo como 'previdente', por oposição ao irmão, Epimeteu, o 'que sabe depois' de as coisas acontecerem.

17 Valendo-se, portanto, da composição em anel, reforçada, de resto, por «voz canta», que se pode ligar a "poemas». 
A versão mais difundida do suplício de Sísifo consiste em colocá-lo a empurrar encosta acima um enorme rochedo que, assim que atingia o cume, voltava a rolar para a base, fazendo com que Sísifo tivesse de começar tudo de novo, para toda a eternidade. Esse trabalho corresponde, por conseguinte, a um castigo duplamente punitivo: por um lado, a tarefa árdua de empurrar a colossal pedra; por outro, a consciência da inutilidade desse esforço, já que, quando o objetivo parece estar atingido, há que repetir a empreitada desde o início. No entanto, o poema de A. Arnaut transforma, de maneira mais positiva, essa contingência da "humana condição». Os ciclos constantes, herdeiros, de alguma forma, do mito do eterno retorno, não obrigam propriamente a refazer vezes sem conta o mesmo caminho, facto que constitui a essência da natureza punitiva do trabalho de Sísifo. O imperativo é outro: «recomeça a obra inacabada». Nesta perspetiva, cada ciclo acrescenta algo de construtivo. A imagem da «espiral da vida» ilustra precisamente essa ideia. Não corresponde a uma repetição inútil, mas antes à noção implícita de progressão contínua, baseada embora em etapas semelhantes. Mais do que uma imposição superior, é um ato deliberado de pesquisa («Sísifo a procurar o pão»), se bem que motivado pela "fome eterna», porventura do conhecimento e da realizaçáo poética.

Em outro poema, A. Arnaut parece desenhar a imagem deste processo in fieri. Ao longo de oito estrofes, o autor interroga-se sobre as grandes forças que determinam o movimento do universo. Nesta composição, que acaba por refletir sobre a dimensão cósmica da poesia, seria de prever que aparecesse de novo o imaginário ligado aos quatro elementos, como efetivamente acontece. Contudo, uma vez que já se examinou a utilização desse simbolismo num outro poema, a análise irá entrar-se agora somente nas estrofes onde ocorre outro tipo de ecos clássicos (II.31):

\author{
$[\ldots]$ \\ Que asa espreita nos olhos \\ a volúpia do céu incandescente \\ quando a lua desposa o Minotauro? \\ $[\ldots]$ \\ Que ansiedade abre a campânula \\ do verso destilado, como gota \\ de Tântalo à beira da Mãe-d'Água? \\ Que orgasmo percorre os raios \\ do Sol levedado sobre o mar \\ quando a luz desvenda o Labirinto?
}


Que secreta revelação,

que mistério escondido nesse fogo

onde as linhas da vida se entrecruzam...?

Só o poeta sabe que procura

a íntima alquimia da palavra.

Para melhor ilustrar os passos e as dificuldades desta indagaçáo sobre as forças que movimentam o universo, A. Arnaut serve-se explicitamente de alguns mitos clássicos bem conhecidos. $\mathrm{O}$ de Tântalo, outro dos supliciados divinos, exprime a «ansiedade» de quem está prestes a atingir o objetivo, que teimosamente escapa no derradeiro momento. O do Minotauro, a que naturalmente se liga a imagem do Labirinto, representa quer as tentativas renovadas para encontrar uma saída, quer os perigos dessa busca, pois existe sempre a possibilidade de a demanda conduzir a um encontro fatídico com o híbrido monstro. O fio de Ariadne que orienta o poeta e lhe dá forças para continuar é a obsessão de procurar «a íntima alquimia da palavra». ${ }^{18}$ A penúltima estrofe, apesar de não conter alusões clássicas óbvias, tende a circunscrever o ato de criação poética a um processo iniciático, a poucos revelado, como ilustram as expressóes «secreta revelação» e "mistério escondido», o que está de acordo com as religióes mistéricas (em especial os mistérios de Elêusis), mas em A. Arnaut obedece a um simbolismo mais abrangente que, como se dizia na abertura deste estudo, remete para o universo dos valores maçónicos. ${ }^{19}$

Ainda assim, a dimensão iniciática da poesia encontra-se também, de alguma forma, enunciada em II.20. A linguagem desta composição pende para o secretismo e para a ambiguidade, acentuada pelo facto de esta ser uma das poucas composiçóes em que o autor prescindiu totalmente dos sinais de pontuação. Desta forma, os versos, com uma fixidez menos rígida, adquirem o caráter de uma espécie de santuário 'profanado' e amontoam-se como despojos trazidos de um tempo pretérito.

Sobre a hera o recado de outras eras

hieráticas colunas remontando

às estátuas de mármore decepadas

18 Cf. II.1: «Busque e rebusque, / o poeta, / o metal exacto / da palavra / insurrecta.»

19 A. Arnaut foi, de resto, Grão-Mestre do Grande Oriente Lusitano durante o triénio de 2002-2005, e vários dos seus livros assumem de forma clara essa ligação à maçonaria. Vide Arnaut 2003a; 2003 b. 
súbitos degraus impassíveis feras

e uma corda de vento pendulando

do silêncio nocturno das arcadas

visão de áspides deslaçando o medo

o sol a lua o místico himeneu

Hierofante erguendo as mãos ao céu

das palavras libertas do segredo

o sinal era o pórtico de Orfeu

O poema repousa sobre restos de um passado helénico, conforme indiciam determinados signos: a «hera» que se liga por homofonia ao «recado de outras eras»; as "hieráticas colunas» que remontam «às estátuas de mármore decepadas». O ambiente recriado está envolvido por uma aura sagrada que favorece a identificação com um templo. ${ }^{20}$ Esse hieratismo vai acentuar-se na segunda estrofe, onde se encontram ecos das três grandes correntes místicas gregas: culto dionisíaco, mistérios de Elêusis e orfismo. ${ }^{21} \mathrm{~A}$ "hera» é um símbolo vegetal de Diónisos e as serpentes (cf. «áspides») faziam parte dos adereços dos membros do thiasos ou cortejo de Sátiros e Ménades que vagueavam pelas montanhas, em companhia do deus. $\mathrm{O}$ «místico himeneu» poderá constituir uma alusão ao casamento sagrado da mulher do arconte-rei com Diónisos, ato que simbolizava a união do deus da fertilidade com a pólis. Este ritual não pertencia propriamente ao culto realizado pelas Bacantes, já que era uma das etapas das Antestérias, festas em honra de Diónisos celebradas em fins de fevereiro, mas também era uma cerimónia rodeada de algum secretismo. Por outro lado, as núpcias referidas poderiam ecoar também a ligação de Hades e de Perséfone, divindades relacionadas com os Mistérios de Elêusis. A reforçar esta hipótese está o facto de que, neste culto de que muito pouco se sabe, um dos pontos altos seria constituído pela aparição do "Hierofante», ${ }^{22}$ que aparece referido precisamente neste poema de A. Arnaut. As "palavras» também assumiam um importante papel no ritual, a ponto de uma das condiçóes de admissão consistir em saber falar grego. Por último, a referência expressa a

20 Cf. a recorrência de signos semelhantes em II.18: «Pedras mortas. Silêncio jacente. / O caos em decomposição. / Apenas a serpente / lavra o exemplo / do fogo sobre o musgo deste chão. / Mesmo em ruínas, o templo / é lugar de inquietação.»

21 Introdução ao estudo das questôes relacionadas com esta faceta da religião grega em Rocha Pereira 2012: 308-323.

22 Cf. Plutarco, De profect. virt., 81e. 
Orfeu remete para a outra grande corrente mística grega, que deriva do seu nome (o Orfismo). Juntando estes elementos de natureza mistérica com o facto de o mito de Orfeu estar profundamente ligado ao poder do canto e da poesia, ganha pertinência a leitura deste poema como expressão do caráter iniciático da linguagem e da criação poéticas. ${ }^{23}$

Além das várias interpretaçóes já adiantadas para a expressão «místico himeneu», foi deixada para o fim uma terceira, segundo a qual essas núpcias poderão referir-se à união entre Orfeu e Eurídice. A morte desta, depois de ser picada por uma serpente (cf. de novo «áspides»), motivará a famosíssima descida aos infernos de Orfeu. Ora A. Arnaut aproveitou de uma forma muito curiosa esta parte do mito, no único poema a que deu título e com o qual encerra o seu livro.

\section{ÍNDICE \\ Empilhados, no inferno do índice os poemas suspiram por Eurídice.}

Os poemas que «suspiram por Eurídice» representam metonimicamente Orfeu, o que reforça a ideia, analisada na última composição, de que a referência a Orfeu significa, também metonimicamente, a produção poética. Por outro lado, o autor inverte os dados do mito: não é Eurídice que se encontra no inferno, mas sim os poemas/Orfeu que esperam a salvaçáo. Uma vez que o inferno está representado pelas grilhetas do «índice», a libertação só pode chegar através da leitura e do canto, aqui simbolizados por Eurídice. Portanto, a poesia/Orfeu anseia pela união com a leitura libertadora/Eurídice. Com esse encontro, A. Arnaut exprime uma das funçóes mais nobres da poesia: vencer a dor da ausência, como se pode constatar noutro poema seu, com cuja leitura se encerra este estudo (II.14):

Perdi-te para sempre e só me resta encontrar-te nos meus versos.

Canto de remorso ou penitência assim o mar me devolvesse os barcos cativos na fundura do cais onde mora e tua ausência.

23 Visão ecoada noutros poemas. E.g. I.3: «Descobrir a palavra secreta: / o poeta é um exorcista, / desde que não desista.» 


\section{Bibliografia citada}

Arnaut, A. (1987), Miniaturais — Outros Sinais. Coimbra: Livraria Almedina.

Arnaut, A. ( $\left.{ }^{3} 2003 a\right)$, Nobre arquitectura. Lisboa: Hugin Editores.

Arnaut, A. ( ${ }^{4} 2003$ b), Introdução à maçonaria. Coimbra: Coimbra Editora.

Arnaut, A. (2004), Recolha poética (1954-2004). Coimbra: Coimbra Editora.

Arnaut, A. (2013), Alfabeto intimo e outros poemas. Coimbra: Coimbra Editora.

Dodds, E.R. (1988), Os Gregos e o Irracional. Lisboa: Gradiva.

Kirk, G. S., Raven, J. E. \& Schofield, M. ( $\left.{ }^{4} 1994\right)$, Os Filósofos Présocráticos. Lisboa: Fundação Calouste Gulbenkian.

Leão, D. F. (1998), "Tradição clássica na poesia de António Arnaut”, Boletim de Estudos Clássicos 29: 113-124.

Leão, D. F. (2008), “António Arnaut e a seiva amorosa de cada verso", Boletim de Estudos Clássicos 50: 79-93.

Rocha Pereira, M. H. ( $\left.{ }^{10} 2009\right)$, Hélade. Coimbra: Guimarães Editores.

Rocha Pereira, M. H. ( ${ }^{112012), ~ E s t u d o s ~ d e ~ H i s t o ́ r i a ~ d a ~ C u l t u r a ~ C l a ́ s s i c a . ~ I . ~ C u l t u r a ~ G r e g a . ~}$ Lisboa: Fundação Calouste Gulbenkian.

\section{Nota final}

Este estudo recupera, no essencial, as linhas da exposição desenvolvidas em Leão 1998, embora com adaptaçóes e análise de novos argumentos. 
Página deixada propositadamente em branco 


\section{Motivos clássicos na poesia novilatina em Portugal - Manuel da Costa}

(Classical motives in neo-Latin poetry in Portugal: Manuel da Costa)

Susana Marques Pereira

Universidade de Coimbra

(marquessusana@vizzavi.pt) 
Página deixada propositadamente em branco 
Resumo - Como toda a produção neolatina desta época, profundamente influenciada, quer no estilo, quer nas ideias, pelos autores clássicos, os motivos da Antiguidade são múltiplos nas composiçôes de Costa, desde logo no próprio formato e no metro escolhido. Assim o epitalâmio, em hexâmetros elogiosos para os noivos e para as famílias respetivas: distingue-lhes as qualidades físicas e intelectuais, bem como a dignidade dos seus comportamentos e atitudes.

Palavras Chave - Renascimento português, epitalâmio, Manuel da Costa

Abstract - As all the neo-Latin production of sixteenth century literature, deeply influenced, in style as in ideas, by the classical authors, Manuel da Costa integrates a lot of conventions from Antiquity in his compositions. Epithalamion, a celebration of weddings and of the families involved in, underlines their physical as well as intellectual qualities, as well as the dignity of their behaviour and attitude.

Keywords - Portuguese Renaissance, epithalamion, Manuel da Costa

A matriz clássica consubstancia-se numa assimilação e numa (re)apropriação multilingue, multiforme, intemporal e universal, como se sabe. A história, a literatura, a língua, o teatro, a filosofia, a mitologia, a arte, a arquitetura, a matemática, a astronomia, a medicina, o direito, a política testemunham a amplitude e a diversidade de domínios influenciados pelo legado da Antiguidade, em espaços e épocas diferenciados. Permeável a sensibilidades, experiências, identidades e contextos variados, a tradição clássica, raiz histórica e cultural, converte-se em manancial de inspiração e de imitação reiteradas, numa revitalização contínua e propiciadora de sentidos renovados.

O humanismo renascentista constituiu um momento de excelência para evidenciar a importância da cultura da Antiguidade também em Portugal, sob formas clássicas de epigramas, odes, longos poemas heróicos ou epitalâmios, por exemplo - "a velha escolástica desmorona e as diuinae litterae dão lugar às humanae litterae como ideal de vida e de cultura, refratando-se em novo meio o eixo teocêntrico em que girava tudo o que ao homem concernia e que doravante assume primado absoluto. (...)

No afã de ressuscitar valores e gostos, da Antiguidade clássica advêm luzes e espelhos, bem como os instrumentos de implantação da nova ordem de viver e de sentir" ${ }^{2}$.

$\mathrm{Na}$ época áurea dos Descobrimentos portugueses, o confronto com o paradigma de outrora, elogioso para os Lusitanos, favorecia a divulgação e

1 Cf. e. g. André 1991-1992: 223 sqq.; Ramalho 1998.

2 Mendes 1991-1992: 412. 
o panegírico da nossa expansão, bem como a celebração das figuras que a proporcionaram e da grandeza do 'peito ilustre lusitano'3 em geral. $\mathrm{O}$ ambiente de epopeia experimentado no país num momento de prosperidade ${ }^{4}$ ganhou forma expressiva n' Os Lusíadas, obra representativa de uma atitude laudatória usual nos autores de Quinhentos ${ }^{5}$, com voz noutros nomes para além de Camóes, ora em português (cf. e. g. António Ferreira, João de Barros), ora em latim (cf. e. g. Diogo de Teive, Inácio de Morais), a língua internacional da época.

O convívio frequente entre humanistas de toda a Europa propiciava a difusão dos feitos portugueses a uma escala alargada - numa valorização evidente dos Lusitanos, que davam a conhecer ao mundo novas terras e novas gentes, os nossos conterrâneos não se poupavam a esforços para fazer cessar 'tudo o que a Musa antiga canta $<$ va $>/$ que outro valor mais alto se alevanta $<$ va $>^{\text {'6 }}$.

Manuel da Costa, jurista de renome e poeta novilatino ${ }^{7}$, fez jus ao espírito do tempo nos dois epitalâmios de tema nacional e contemporâneo que escreveu em latim: em tom encomiástico, cantou as núpcias do infante D. Duarte com D. Isabel de Bragança, em 1552, e um ano depois, o matrimónio do príncipe João, herdeiro de D. João III, com a princesa Joana de Castela.

"Como toda a produção neolatina desta época (...), profundamente influenciada, quer no estilo, quer nas ideias, pelos autores clássicos e em especial latinos"8, os motivos da Antiguidade são múltiplos em ambas as composiçóes de Costa, desde logo no próprio formato e no metro escolhido: o epitalâmio, género cultivado já por autores da Antiguidade como Safo, Teócrito, Catulo, Claudiano ou Estácio, em hexâmetros elogiosos para os noivos e para as famílias respetivas, distinguindo-se qualidades físicas e

3 Camões, Os Lusíadas 1.3.5.

4 A este propósito, cf. e. g. Matos 1984; André 1991-1992: 218 sqq.

5 Como observa Ramalho 1998: 23, a exaltação de personagens ilustres na literatura "era uma prática a que os humanistas se prestavam, na busca de proteçáo e de honras materiais".

6 Cf. Camões, Os Lusíadas 1.3.7-8. Ramalho 1998: 36 salienta precisamente que "a referência aos Gregos e aos Romanos para valorizar os Portugueses vai ser repetida depois na literatura em Portugal do século XVI até cristalizar nos versos de Os Lusíadas". Sobre a importância concedida à influência da Roma antiga em particular n' Os Lusíadas, obra em que os Portugueses são "frequentemente comparados aos povos da Antiguidade, imagética mítico apoteótica do Renascimento", cf. Rodrigues 1999: 183-218.

7 Outros juristas portugueses do Renascimento aliaram o Direito ao cultivo das Letras, como Pedro Sanches, Miguel e António de Cabedo (cf. Ramalho 1988: 187).

8 Soares 2010: 81. 
intelectuais dos mesmos, bem como a dignidade dos seus comportamentos e atitudes?.

A presente reflexão ocupa-se do Carme heróico sobre as núpcias de João e Joana, serenissimos principes da Lusitânia, também conhecido como Proteu: o enlace do único filho sobrevivente de D. João III e de D. Catarina, vital para assegurar a sucessão dinástica portuguesa e a independência da nação, difundia por todo o reino uma tonalidade de alegria e de esperança, cantada igualmente por outros poetas quinhentistas, como Diogo de Teive ou António Ferreira ${ }^{10}$ - o júbilo contagiava os Lusitanos em geral, em particular pelas implicações políticas que o casamento assumia para a pátria ${ }^{11}$. Como é sabido, as alianças matrimoniais entre a Casa Real Portuguesa e a corte castelhana revelaram-se estratégicas para estreitar laços e para garantir a paz entre os reinos peninsulares, durante a soberania de D. Manuel I e de D. João III.

Poema de assunto histórico e de natureza claramente celebrativa, o carme de Manuel da Costa recorre com frequência à comparação dos Portugueses e dos vizinhos Castelhanos com divindades, heróis e povos da Antiguidade, procedimento muito comum no Renascimento, como ficou dito, e também nos epitalâmios - o paralelo com referentes singulares, por norma excedidos pelos homens de Quinhentos, engrandece os contemporâneos de Costa, poeta áulico e distinto conhecedor da arte da eloquência, e proporciona-lhe a exibição de uma erudição inspirada em modelos greco-latinos, muito valorizada na época.

Para lá dos nomes tradicionais associados à composição de epitalâmios na Antiguidade, os Poemas Homéricos, Hesíodo, Eurípides, Virgílio são decerto textos/ autores que o poeta novilatino conhecia, no original ou em tradução ${ }^{12}$, e de que se serviu para escrever os seus carmes (cf. e.g. imitatio dos versos $387-$ 389 do canto IV das Geórgicas, nos primeiros quatro versos do poema, ou do verso 518 do canto VII da Eneida, no verso 155; alusão a episódios como o encontro de Nausícaa e Ulisses na ilha dos Feaces, ou a retenção da armada grega em Áulide devido à ausência de ventos para navegar).

9 Sobre a evolução do epitalâmio desde a Antiguidade, cf. Sánchez-Marín 1992: 200-201.

10 Cf. Diogo de Teive, oração e carme em honra deste matrimónio; António Ferreira, écloga Arquigâmia, soneto 2.17, ode 1.2.

11 A propósito do amor destes príncipes, reiteradamente cantado pelos autores de Quinhentos, cf. Soares 2010: 291, n. 101. Sobre a realização do casamento, cf. Andrade 1976, cap. 95.

12 A propósito da difusão dos clássicos na Europa no século XVI, cf. Rodrigues 1999: 212, bem como as referências bibliográficas aí sugeridas. 
A seleção específica dos motivos clássicos presentes no poema permite pressagiar felicidade para os nubentes, delinear referências geográficas, explicitar a origem de topónimos, mencionar notaçóes cronológicas, caraterizar a governação do monarca reinante, comparar divindades e heróis da Antiguidade a personagens ilustres da época, estabelecer paralelos entre situações de outrora e do século XVI, ou ainda traduzir estados de alma.

$\mathrm{O}$ relato dos festejos celebrativos do matrimónio dos príncipes João e Joana é auspiciosamente colocado na boca do divino Proteu, na parte inicial do poema - a famosa capacidade profética daquele deus marinho e polimórfico sugere um cenário venturoso para noivos tão distintos, descendentes de ilustres famílias, e para núpcias tão esplendorosas ${ }^{13}$.

A narração de Proteu surge em resposta à curiosidade das Nereides face ao tumulto experimentado no mar dos Cárpatos: um magnífico cortejo divino se apresta rumo ao Ocidente. A comitiva congrega prestigiosamente divindades do amor, por natureza associadas à celebraçáo de epitalâmios, como Vénus, Cupido e Himeneu, e deuses marinhos, de que se destacam Neptuno e Tritão, cuja presença honrosa remete para a identidade marinheira dos Portugueses e para a prosperidade resultante da expansão marítima lusitana e, por outro lado, evoca uma fecundidade almejada para o trono nacional, simbolizada na água, fonte de vida e de fertilidade. A cooperação de divindades representativas de diferentes domínios expressa o patrocínio generalizado do mundo supra-humano ao casamento real celebrado ${ }^{14}$.

A referência genérica ao local de destino do cortejo, 'as costas de Febo cadente', permite a alusão ao trajeto diário daquela divindade, que percorria o céu num magnífico carro puxado por cavalos, desde o Oriente até ao seu declínio no Ocidente, episódio ilustrativo da visão geocêntrica do universo, comum no século XVI. O recurso à mitologia clássica para delimitar a geografia é reincidente no poema, proporcionando a exibiçáo da cultura de Manuel da Costa, como convinha. Assim acontece a propósito da menção mais precisa ao espaço luso onde decorriam as grandiosas festividades, Lisboa, designada como 'a cidade que recebeu de Ulisses o nome', numa perífrase elucidativa da etimologia do topónimo da capital portuguesa. Lisboa

13 Malogradamente, porém, a alegria destas núpcias seria contraposta por uma dor profunda, como é sabido, já que cerca de um ano depois, a 2 de janeiro de 1554, o príncipe viria a falecer, deixando a esposa grávida de um filho, D. Sebastião. Sobre o tratamento do tema da morte de D. João na poesia quinhentista, cf. Soares 2010.

14 António Ferreira, na écloga Arquigâmia, evidencia também a presença prestigiosa das divindades do Olimpo na chegada de D. Joana a Lisboa, para casar com o príncipe herdeiro da coroa portuguesa. 
é ainda reclamada, mais adiante, como 'a cidade de Marte', seja porque a chegada da noiva oriunda de Castela à urbe portuguesa é aclamada ao som de disparos de canhóes, numa toada evocativa da guerra, apanágio de Marte, e na qual os Portugueses se distinguiram, seja também pelo facto de as nossas armadas partirem de Lisboa para as suas conquistas e descobertas.

A erudição etimológica e mítica do poeta revela-se ainda na identificação da lusitana pátria como 'o reino de Luso', origem que Camôes confirma n' Os Lusiadas 3.21.5-7:

"Esta foi a Lusitânia, derivada
de Luso ou Lisa, que de Baco antigo
filhos foram, parece, ou companheiros ${ }^{15}$.

A natureza associa-se sintomaticamente à alegria da ocasiáo, como era hábito nos epitalâmios, presenteando os noivos com um tempo bonito e luminoso. O poeta novilatino expressa estas notaçóes cronológicas através da menção a Láquesis, que tece o dia de um branco propício, evocativo da pureza $^{16}$, como em Catulo 64, 350 sqq., e ao Titá Sol, o qual concede a sua luz radiante à jornada ditosa que unirá os jovens noivos.

A travessia do Tejo, de Lisboa ao Barreiro, por D. João III, ao encontro da princesa que chega do reino vizinho, destinada a seu filho, João, produz o momento oportuno para enquadrar o governo do monarca reinante na Idade de Ouro, procedimento comum entre os humanistas de Quinhentos, evocativo da criaçáo hesiódica do mito das cinco idades, temática que teve um tratamento amplo ao longo dos tempos, como se sabe ${ }^{17}$. A justiça e a observância da lei são as caraterísticas que Costa elege para colocar panegiricamente D. João III como o introdutor daquela idade preciosa no reino de Luso, destacando-o como um bom rei, como uma figura paradigmática para o seu povo, que se impunha pelas suas virtudes e pela sua excelência ${ }^{18}$. De resto, a dignidade do soberano português é ainda sublinhada por uma imagem retirada da natureza: a presença e a autoridade de D. João III instigam o ar tempestuoso a serenar, sendo apenas

15 Sobre a origem da palavra 'Lusíadas', cf. Ramalho 1983: 221-236.

16 A propósito da simbologia da cor branca, cf. Chevalier e Gheerbrant 1982: 128130, s. v. 'branco'.

17 A este propósito, cf. Soares 2010: 268-269.

18 Sobre o conceito de realeza e a imagem do bom rei, tema que constitui um lugarcomum, cf. Soares 2010: 100-108; Beau 1957: 176-221. 
permitida uma suave brisa ao Zéfiro, que coopera de modo agradável na breve viagem a caminho de um destino que se deseja de amor e de felicidade.

Diversas figuras eminentes acompanham D. João III até à outra margem do Tejo, percurso que o poeta novilatino aproveita para, com intuito laudatório, aproximar Lourenço Pires de Távora, designado como procurador do príncipe Joáo para tratar do seu enlace com D. Joana de Castela, de um modelo do passado, o herói Tideu, pai de Diomedes e outrora enviado a Tebas com o propósito de convencer Etéocles a permitir que Polinices tomasse o governo do reino. Para além de ambos serem incumbidos de missóes diplomáticas, Lourenço Pires de Távora, personagem coeva de Costa, distinguiu-se de modo particular pelo seu valor militar no norte de África ${ }^{19}$, e os seus feitos são apresentados como mais notáveis do que os do ilustre Tideu, que aniquilara inúmeros Tebanos, evidenciando a superioridade portuguesa no que ao mérito guerreiro diz respeito (o mesmo sentimento é destacado por Camóes n' $O s$ Lusíadas - cf. as razóes evocadas por Vénus e por Marte para que se apoiassem os Portugueses no episódio do consílio dos deuses no Olimpo, no canto I).

O regresso da comitiva a Lisboa, com D. Joana a bordo, ocasiona o retardado encómio da noiva, cuja singular beleza física é comparada à de figuras míticas, como é próprio dos epitalâmios: a jovem princesa Nausícaa e a nereide Tétis são as personagens escolhidas para o paralelo estabelecido, porquanto os episódios que protagonizam, associados ao tema do encontro e do amor, ocorrem em ambientes situados junto à água. A individualidade da noiva castelhana, cuja excelência Manuel da Costa pretende exaltar, dispensa a menção ao elemento masculino que completa o par de forma explícita no mito, respetivamente Ulisses e Peleu. Na senda do tom encomiástico habitual na poesia quinhentista, a formosura de D. Joana suplanta a das demais figuras femininas.

$\mathrm{Na}$ trajetória efetuada no Tejo, surge a oportunidade para uma menção breve ao séquito feminino que acompanhava a nubente, realçando-se de modo genérico os atrativos físicos das acompanhantes de D. Joana, enaltecidas ao serem identificadas como Ninfas.

A sumptuosidade da armada que conduzia a noiva a Lisboa, expressiva da prosperidade vivida no reino na época dos Descobrimentos, convida a recordar a imensa e poderosa frota grega outrora retida em Áulide ${ }^{20}$ : elogiosamente, os barcos lusitanos superam os helénicos, no aparato e em número.

19 A propósito da biografia de Lourenço Pires de Távora, cf. Machado 1752, t. III; Caetano de Sousa 1950, t. IV; Sousa 1938: 290-293.

20

Cf. Eurípides, Ifigénia em Aulide, 231-302. 
A exaltação da família real da noiva não é esquecida, na insigne figura de Carlos V, seu pai, pelas conquistas que obteve. Os feitos do soberano de Castela são laudatoriamente comparados a um exemplum da história de Roma antiga, César Augusto, conquistador paradigmático, com o qual Carlos V é identificado, embora desta feita Manuel da Costa se esquive a afirmar que o chefe do reino vizinho ultrapassou os heróis da Antiguidade, ao contrário do que faz de forma reiterada ao longo do carme em relação aos Portugueses seus conterrâneos.

Entrecruzando passado próximo e circunstâncias presentes, o poema faz uso de um processo épico já usado nos Poemas Homéricos (cf. Il. 18. 478 sqq.), a descrição de acontecimentos por meio de objetos: na verdade, saindo das profundezas douradas $<$ do Tejo $>$, as Náiades trazem como presente uma colcha nupcial, tecida para uso do leito de Joana, para que se possa ver Afonso Henriques e, por ordem, os reis lusitanos, ascendentes de sua mãe (136-140). De modo oportuno - e laudatório -, o puluinar geniale oferecido à noiva, evocativo do concedido outrora à divina Tétis (cf. Cat. 64, 47 sqq.), mostra cenas referentes à história de Portugal, desde D. Afonso Henriques. Arguto, Manuel da Costa, a quem chamavam doctor subtilis, descreve com particular detalhe o nascimento extraordinário do monarca reinante, D. João III, aludindo à auspiciosa intervenção divina no parto do mesmo. As divindades que assistem à sua vinda ao mundo ilustram caraterísticas definidoras do seu reinado, prenunciando-lhe felicidade: a Paz, Astreia, deusa da justiça, e as Musas, alusivas à proteção que o monarca concedeu às Letras.

A chegada da noiva a Lisboa permite ao poeta passar para um cenário interior, mais íntimo e propício à expressáo de sentimentos e emoçóes, o palácio, onde o príncipe João aguarda a noiva com ansiedade, junto de sua mãe, a rainha D. Catarina. Naturalmente, Manuel da Costa louva ambas as figuras, selecionando de modo significativo a divina Anfitrite para o confronto que estabelece entre a beleza e os dotes de alma daquela e os da esposa de D. João III - como Anfitrite é senhora do mar, assim também D. Catarina era soberana de um povo de ilustres marinheiros e de um país que abria ao mundo novas paragens e culturas, a partir do Tejo; os papéis de mãe e de rainha entrelaçam-se, mesclando os domínios pessoal e público.

O louvor das virtudes do príncipe herdeiro, por seu turno, converteu-se em matéria cantada por diversos autores quinhentistas ${ }^{21}$ - no Proteu, porém, referem-se de modo genérico aquelas que refletem qualidades paternas

21 A este propósito, cf. Soares 2010: 47-50, 279. 
(dignidade, majestade), para se descrever em seguida o estado de alma de D. João, noivo ansioso pela chegada da jovem princesa.

A derradeira menção a motivos inspirados na Antiguidade clássica ajusta-se de modo harmonioso ao tema do carme, quer porque alude a um enlace expressivo da fusão natural entre o Sol e a Luz que ele encerra e com a qual ilumina o mundo, quer também porque confere uma tonalidade luminosa ao final do poema, pela comparação do ânimo de D. João, cuja amada se aproxima, com o do Sol radioso, prestes a desposar a chama da $\mathrm{Luz}^{22}$. Tal casamento no domínio mítico é prestigiosamente conduzido pelo "auspicioso pai omnipotente e por Juno prónuba", deuses cujos epítetos "permitem ao autor aludir a dois ritos do matrimónio romano, que costumam aparecer no epitalâmio clássico: o sacrifício augural inicial, em que se tomavam os auspícios para a nova união (cf. St., S. 229), e a assistência da pronuba ou matrona à noiva, especialmente unindo a sua dextra à do noivo (St., S. 239)", como bem notou Sánchez Marín 1992: 212.

Neste ambiente cintilante, prenunciador de bom augúrio para o futuro da pátria lusa e da coroa portuguesa, Proteu podia recolher-se com tranquilidade à sua morada, terminada a narração, pois no mar dos Cárpatos já anoitecera, embora os raios da Lua conferissem brilho e claridade ao meio envolvente.

Numa época em que a cultura e a civilização clássicas são sobremodo valorizadas na Europa em geral, enquanto modelos a igualar ou mesmo a ultrapassar, a diversos níveis, os autores portugueses de Quinhentos destacam os conterrâneos, agentes de uma prosperidade sustentada pelo governo justo dos seus soberanos ${ }^{23}$. Neste enquadramento se posiciona Manuel da Costa que, recuperando episódios e figuras do mito e da história antigos, exibe os seus conhecimentos e testemunha a relevância da matriz clássica na sua época.

22 O confronto entre o Sol, gerador de clareza e de luminosidade, e o bom rei surge noutros autores de Quinhentos: cf. Soares 2010: 100-101, 298.

23 Ilustra no entanto André 1991-1992: 233 sqq. como, a par do encómio frequente de múltiplos autores da época, se notava também com alguma insistência uma crítica, mesmo que velada, a aspetos negativos da expansáo ultramarina portuguesa, porque "o poder corrompe, a fama ofusca, a riqueza cega. Sabiam-no os Gregos, que apelavam constantemente à moderação. Não o respeitaram os Romanos que trilharam o caminho da degradação até à queda do império" (idem, ibidem: 233). 


\section{Bibliografia}

Andrade, F. (1976, reimpr.), Crónica de D. João III. Introd. e rev. de Almeida, M. Lopes. Porto: Lello Editores.

André, C. (1991-1992). "Luz e penumbra na literatura humanista dos Descobrimentos", Humanitas 43-44: 217-256.

Beau, A. E. (1957), “A realeza na poesia medieval e renascentista portuguesa-II,”, Boletim de Filologia 16. 3-4: 176-221.

Chevalier, J., Gheerbrant, A. (1994), Dicionário dos símbolos - mitos, sonhos, costumes, gestos, formas, figuras, cores, números. Trad. de Rodriguez, C., Guerra, A. Lisboa: Teorema.

Machado, D. B. (1752), Biblioteca Lusitana. III. Lisboa: Atlântida editora.

Marques, S. (2005), Dois epitalâmios latinos de Manuel da Costa (século XVI). Introdução. Tradução. Notas e comentários. Coimbra: Instituto de Estudos Clássicos, FLUC.

Matos, L. (1991), L'expansion portugaise dans la littérature latine de la Renaissance. Pref. de J. Pina Martins. Lisboa: Fundação Calouste Gulbenkian.

Mendes, J. P. (1991-1992), "Homo rhetoricus: retórica e Descobrimentos”, Humanitas 43-44: 411-423.

Miguel Mora, C. (1999), “As leituras dos humanistas: fontes secundárias de Manuel da Costa”, Ágora. Estudos Clássicos em Debate 1: 133-154.

- 1999. Raizes greco-latinas da cultura portuguesa. Acta do I Congresso da APEC. Coimbra: Classica Digitalia.

Ramalho, A. C. (1983), Estudos sobre o século XVI. Lisboa: INCM.

Ramalho, A. C. (1988-2000), Para a história do humanismo em Portugal: I (Coimbra, 1988); II (Lisboa, 1994); III (Lisboa, 1998); IV (Lisboa, 2000).

Rodrigues, N. S. (1999), “Camões e a história da Roma antiga”, in Raizes greco-latinas da cultura portuguesa: $183-218$

Sánchez-Marín, J. A. (1991-1992), “Caracteristicas de la obra poética de Manuel da Costa”, Humanitas 43-44: 257-274.

Sánchez-Marín, J. A. (1992), "Un epitalamio latino: el carmen Proteus de Manuel da Costa", in Miscelânea de estudos em honra do Prof. A. Costa Ramalho. Coimbra, INIC: 199-213.

Soares, N. N. C. (2010, $3^{\mathrm{a}}$ ed.), Diogo de Teive. Tragédia do príncipe João. Coimbra: $\mathrm{CECH}$. 
Sousa, A. C. (1950), Provas da história genealógica da Casa Real portuguesa. IV. Coimbra: Atlântida.

Sousa, Frei L. (1938), Anais de D. João III. Prefácio e notas de Lapa, M. Rodrigues. Lisboa: Sá da Costa.

\section{Nota final}

Este trabalho corresponde, em parte, ao apresentado no Congresso Internacional $O$ melhor de tudo é a água. Real e simbólico: da Antiguidade aos nossos dias (Coimbra, 7-8 de março de 2013). 


\title{
Uma Ifigénia portuguesa: Noite escura de Joáo Canijo
}

(A Portuguese Iphigeneia: "Noite escura" by João Canijo)

\author{
Nuno Simóes Rodrigues \\ Universidade de Lisboa \\ (antiguidadeclassica@hotmail.com)
}


Página deixada propositadamente em branco 
Resumo - O fascínio de Canijo pela tragédia grega tem-se revelado em várias das suas realizaçôes cinematográficas. O próprio confessou em entrevista: 'descobri que nas tragédias gregas e em Homero estão os arquétipos não só das histórias como das personagens de sempre da nossa tradição ocidental. $\mathrm{O}$ único que inventou depois alguma coisa foi Shakespeare. Tudo o resto parte dos Gregos'. É este o espírito que ditou a sua Noite escura, uma Ifigénia portuguesa.

Palavras chave - cinema, mito, trágico, Atridas.

Abstract - The attraction of Canijo for Greek tragedy is clear in several of his films, as has been declared by the filmmaker himself: 'I discovered that Greek tragedy and Homer are the archetypes not only of the stories but also of the permanent figures of the western tradition. The only author who invented something later was Shakespeare. Everything else comes from the Greeks'. This is the spirit that inspired Noite escura (Dark Night), a Portuguese Iphigeneia.

KeYwords - cinema, myth, tragic, Atreidae.

Nelson Pinto é o rei da noite. É assim que a mulher, cujo nome - Celeste - não pode ser mais antitético da personagem a que dá corpo, o caracteriza numa sequência do filme que ambos protagonizam: Noite Escura.

Com efeito, a noite é escura e longa. A alumiá-la, apenas vislumbres de focos intensos, de cores carregadas, em tons de azul ferrete e vermelho sangue, que esmagam de claustrofobia os que por elas se guiam. $\mathrm{O}$ resultado é o ambiente sórdido e soturno, lúgubre e sombrio de um bordel ou casa de alterno de província, localizada algures no Portugal que hoje se convencionou chamar de "profundo». Tivesse o ecrã a capacidade de transmitir o sentido do olfacto e cheirar-nos-ia por certo a perfumes ordinários, desodorizantes de propulsor quiçá armazenados em pulverizadores de loja chinesa, misturados com álcool e tabaco, e ainda ao bafio acre da transpiração de corpos que na calada da noite se entregam a actos considerados ilícitos pela moral dominante em fusão com os tecidos baratos que forram divãs e sofás.

Tudo se passa numa noite e a noite é escura. Nelson (Fernando Luís) e Celeste (Rita Blanco) gerem o seu negócio: ele administra-o, o que implica contactos marginais com mafias de leste; ela controla os espectáculos que todas as noites entretêm a clientela. O casal tem três filhos: Carla, Sónia e Manuel (Luís Simóes), uma criança que inocente se passeia mascarada de super-herói por entre as «meninas» do bordel, alheia a toda a sordidez que se vive à sua volta. Carla (Beatriz Batarda) é a mais velha, rapariga de 24 anos, apagada, mal vestida e de aparelho metálico nos dentes, que faz a manutenção do espaço, limpando o que ficou sujo da noite anterior. Sónia (Cleia Almeida), 18 anos de ingenuidade, debuta como cantora da noite, longe, 
todavia, de ser um talento. Mas é nisso que todos parecem querer acreditar. A este núcleo familiar juntam-se quatro outras personagens: Nicolau (José Raposo), o amigo de Nelson; Sebastiáo (Ramón Martinez), o namorado de Sónia; o amante de Celeste (João Reis); e Fyodor (Dmitry Bogomolov) ${ }^{1}$, o mafioso que trata com o dono do bordel.

Nelson pisou o risco. Parece ter dado um passo maior do que as pernas. E a dívida contraída aos russos náo consegue agora ser saldada. Fyodor propóe uma solução: a entrega da filha mais nova, Sónia, à mafia russa poderá saldar a dívida e resolver o problema. O dilema cai sobre Nelson. A angústia dilacera-o. Mas o homicídio de uma das «meninas» do bordel, de uma russa precisamente, horas antes, de cujo sangue e corpo Carla tratou de limpar em todos os sentidos, não deixa espaço para dúvidas. Nelson tem de aceitar a proposta de Fyodor ou a dívida poderá sair-lhe demasiado cara. Nicolau tenta ajudar o amigo e faz-se forte perante os russos. Mas a força de Nicolau é fogo-fátuo, especialmente manifesto no momento em que Fyodor lhe crava um punhal no pescoço. Nelson náo tem saída, a menos que ponha em jogo a sua própria vida e as dos seus.

A todo este processo, Celeste e Sónia mantêm-se alheias. A primeira parece preocupar-se com coisas fúteis, desde o peeling que pretende fazer e que é consonante com a sua cabeleira platinada e oxigenada (em Celeste, as cores parecem ser particularmente simbólicas, como o vestido vermelho que usa qual sintoma de perdição e prenúncio da tragédia), às repreensôes sem sentido que faz à filha mais velha, inclusive no meio de um chão e paredes ensanguentadas, em que nem sequer parece reparar, e ao encontro proibido com um amante que a faz trair Nelson debaixo dos olhos dele e desse modo reviver os seus tempos de prostituta. A segunda, comparada a uma pomba inocente, persegue o sonho de vir a ser uma estrela da cançáo, apoiando-se num namorado demasiado passivo. $\mathrm{O}$ pai aproveita o sonho e alimenta-o com o dolo: os russos aceitaram levar Sónia para Espanha, onde se estreará como cantora. Ao princípio, Sónia acredita na ilusão.

Em contrapartida, Carla, uma espécie de Gata Borralheira, percebe tudo o que ali se passa. A ela nada parece escapar. Carla é a personagem mais lúcida desta Noite Escura. Talvez por isso ela não acredite em sonhos nem em milagres e náo hesite em deixar cair uma imagem de Santa Rita de Cássia, também esta vítima de um marido cruel e patrona das causas impossíveis, no caixote do lixo. Como foi já notado, o acto de Carla parece

1 O realismo do filme leva o realizador a optar por actores nativos para os papéis de russos. 
sugerir que ali não há espaço para a piedade ${ }^{2}$. A atitude da jovem, contudo, parece-nos também um símbolo da rejeição e do repúdio do religioso, como num "piscar de olhos" ao espectador mais entendido, dizendo-lhe logo naquela sequência inicial da película: «aqui não há Ártemis a exigir um sacrifício! Aqui os deuses foram esquecidos! Aqui são os homens que se encarregam de trazer a tragédia aos seus semelhantes!»

Mas a percepção que Carla tem da realidade é também a matéria-prima que a enredará na que há-de ser a sua tragédia do conhecimento. É que Carla sabe demais. Ou melhor, está demasiado consciente da realidade que a mãe persiste em ignorar, e por isso demasiado só ${ }^{3}$. Carla sabe dos crimes do pai. Sabe dos devaneios amorosos da máe. Sabe qual vai ser o destino da irmã. Eventualmente, Carla é quem tem a maior consciência da dimensão trágica de tudo o que está prestes a acontecer e, como tal, ali ninguém sofre mais do que ela. É por isso que Carla agirá, determinada a salvar Sónia do sacrifício a que o pai a entregou.

Depois de se estrear como cantora, Sónia terá de fugir para Lisboa. Carla tomará o seu lugar com os russos. Finalmente, a máe percebe o acordo que o marido fez e ameaça-o: se ele entregar Sónia, ela mata-o. Mas Nelson não tem alternativa. Celeste está resoluta. E nem a oferta que Carla faz para assumir o lugar da irmá a dissuade. Pelo seu lado, Carla tenta convencer o pai a entregá-la no lugar de Sónia. A rapariga tenta tudo. Recorrendo inclusive à tentação da carne, relembrando ao pai o incesto que, aparentemente, com ela comete desde há muito. Mas nada resulta.

Por fim, Sónia resigna-se. A jovem percebe que não há saída e entrega-se aos russos. Carla, porém, náo vencida, pega numa arma e dispara contra os homens que levam a sua irmá. Alguns caem, mas outros reagem e a Electra portuguesa cai ferida de morte. Ao seu redor, todos parecem estar atónitos. Nelson deita-se sobre o corpo da filha, como se com ela fizesse amor pela última vez. Sónia entra no carro dos russos e abandona a cena em direcção ao desconhecido. Celeste reza um Pai-Nosso e cumpre o que prometeu: mata o marido. Mortes nuas e cruas, aos olhos de todos, sem que seja preciso um mensageiro que as relate à audiência.

Não será por certo necessária a confissão de João Canijo para que um espectador ilustrado de Noite Escura se aperceba de que estas personagens evocam outras com mais de dois mil e quinhentos anos de existência. Nelson,

2 I. Monteiro, no blog Godard is dead, Novembro de 2011.

3 Sobre a solidão do herói trágico moderno, vide Williams 2002: 37; sobre a tragédia do conhecimento, vide Serra 2006: 395-437. 
o rei da noite, é Agamémnon; Celeste é Clitemnestra; Sónia é Ifigénia e Carla é Electra. Uma vulgar família portuguesa revela-se subitamente como aqueles que, na noite dos tempos, se deram a conhecer como a casa real de Micenas ou de Argos.

A verdade é que o fascínio de Canijo pela tragédia grega, e em particular pela figura de Electra, tem-se revelado em várias das suas realizaçóes. $\mathrm{O}$ próprio confessou em entrevista: «descobri que nas tragédias gregas e em Homero estão os arquétipos não só das histórias como das personagens de sempre da nossa tradição ocidental. $\mathrm{O}$ único que inventou depois alguma coisa foi Shakespeare. Tudo o resto parte dos Gregos» ${ }^{4}$.

Essa consciência manifesta-se em pelo menos três das suas criações cinematográficas: Ganhar a Vida (2001), em que a personagem de Cidália (Rita Blanco) é uma espécie de Antígona; Mal Nascida (2007), em que o realizador recria uma vez mais em ambiente português a Oresteia, da qual se destaca a figura de Lúcia/Electra (Anabela Moreira); e Noite Escura (2004), em que tudo gira em torno de uma Ifigénia portuguesa. Para este argumento, Canijo contou ainda com a colaboraçáo de Pierre Hodgson e de Mayanna von Ledebur. A produção é de Paulo Branco. O resultado é um filme brilhante - apesar da lugubridade - denso e profundo, na linha de Mike Leigh e John Cassavetes, de quem Canijo se confessa admirador, e aos quais acrescentaríamos ainda Pedro Almodóvar, dado o tom anti-heróico e o fascínio pelas personagens femininas. Mas cabe a cada espectador interpretá-lo à sua maneira. Esse é, aliás, o desígnio do autor, quando opta, por exemplo, por oferecer à sua audiência dois e três diálogos/planos em simultâneo.

Em Noite Escura, há também um pai que de súbito se vê obrigado a entregar uma filha em sacrifício (Nelson/Agamémnon). Há uma mãe que ama essa filha e que desespera quando se vê na iminência de a perder numa teia que a ultrapassa, por um lado, mas que por outro ela ajudou a tecer (Celeste/Clitemnestra). Há um irmão ainda criança (Manuel/Orestes), um desejado mas impotente noivo que nunca virá a sê-lo (Sebastião/Aquiles) e um amante (evocando Egisto) a quem a mãe parece estar intensamente ligada. É esta a forma escolhida por Canijo para recriar a tragédia atribuída a Eurípides, Ifigénia em Áulis. À maneira dos Gregos, Canijo compóe a sua Ifigénia, trazendo à colação outros elementos do ciclo troiano, como é o caso da introdução de Electra neste enredo.

4 Em entrevista a J. Antunes, "João Canijo estreia Mal Nascida», JN 8 de Outubro 2008. 
Com efeito, o realizador português opta por inverter a ordem dos factores. Mantém duas das filhas do Atrida, Electra e Ifigénia, o jovem que evoca Orestes e esquece Crisótemis, todavia relembrada na tragédia euripidiana ${ }^{5}$. Mas opta por fazer de Ifigénia a mais nova e de Electra a mais velha. E todo o papel que esta há-de desempenhar em Coéforas de Ésquilo e nas tragédias suas homónimas de Sófocles e de Eurípides é antecipado para o cenário montado para o enredo desta Ifigénia num alcouce. Esvazia-se o protagonismo de Orestes, que assim nunca o será, e acentua-se a ligação entre pai e filha, ao mesmo tempo que se revela o afastamento quase total em relaçáo à mãe. Note-se que, só no final, ao morrer, Carla chama "mãe» a Celeste. Até então, a jovem trata sempre a mulher pelo seu nome próprio, como que não lhe reconhecendo a maternidade ou como simplesmente mais uma concorrente à atenção de Nelson. Não podemos deixar de assinalar que esta opção de João Canijo parece ser já produto de uma hermenêutica influenciada pela escola psicanalítica, de que o nome de Jung é particularmente relevante, ao teorizar, na sequência de Freud e do «seu» Complexo de Édipo, o Complexo de Electra ${ }^{6}$. A relação entre Carla, Nelson e Celeste é, efectivamente, um paraíso para a psicanálise.

Se, por um lado, Canijo transpóe a tragédia grega antiga para o ecrã, actualizando-a - note-se como Nelson é um rei no seu microcosmos -, por outro parece-nos também evidente que nesta actualização há uma necessária redefiniçáa do trágico, produto de um longo processo cultural que se iniciou no século $\mathrm{V}$ a. C. com os Gregos, mas que náo mais parou. Com efeito, de certo modo, a tragédia antiga, com as suas especificidades sócio-político-religiosas, nasceu e morreu na Atenas do século $\mathrm{V}$, mas a essência do trágico enquanto valor ou ideia filosófica manteve-se na cultura ocidental, sobrevivendo às vicissitudes dos tempos e adaptando-se às suas idiossincrasias. É assim que falamos de tragédia renascentista e neoclássica, romântica e liberal, contemporânea e pós-moderna, burguesa e psicológica ${ }^{7}$. O homem trágico metamorfoseou-se de acordo com os tempos em que foi ressurgindo.

Ao longo desse percurso, durante todo o processo, o príncipe aristotélico cujo destino, em última análise, implicava o da cidade ou comunidade que representava transformou-se num homem comum, viva ele em que época viver. Assim o mostrou, e.g., Arthur Miller com John Proctor,

\footnotetext{
5 E. IA 731; cf. Electra de Sófocles, em que Crisótemis é uma das personagens.

6 Vide e.g. Freud 2010.

7 Vide Williams 2002.
} 
em The Crucible (1953), ou com Willy Loman em Death of a Salesman $(1949)^{8}$. Nestes dois casos, e poderíamos citar outros, a tragédia instala-se entre os anónimos e pode revelar-se em condiçóes de conflito com o Estado ou outra realidade externa ao herói, que regulamente a ordem em que ele se insere, como acontece no primeiro caso, ou em dilemas que se agudizam no espírito das personagens e as fazem entrar em rota de colisão consigo mesmas ou com as suas convicçóes, sonhos e aspiraçóes, tal como sucede no segundo exemplo.

Por um lado, Canijo parece seguir esta nova experiência trágica, como se estivesse atento às palavras de Camus: «o público está cansado dos Atridas, de adaptaçôes da Antiguidade, daquele sentido trágico moderno que, infelizmente, raras vezes está presente em mitos antigos, por mais generosamente recheados de anacronismos que eles sejam.» ${ }^{9}$ Com efeito, os heróis de Canijo são do mais vulgar que podemos conceber: chulos e prostitutas misturados com uma família ordinária. Note-se como até os nomes das personagens apontam nessa direcção - e recordamos que a onomástica é sociologicamente significativa: as filhas de Nelson náo se chamam «Maria Teresa» ou «Maria Francisca»; chamam-se "Carla» e «Sónia», nomes que traduzem uma acentuada moda social vinculada no tempo e no espaço, como um Sitz im Leben determinado e significados sociológicos múltiplos e pertinentes. Não há dúvida de que, neste quadro, a família se revela como uma alternativa ao Estado, sendo no seio dela, por meio da incomunicabilidade dentro dela, que a tragédia se vai consumar ${ }^{10}$. A linguagem é rude e popular. A condizer, música de fundo, com canções de Ágata, Romana e Tony Carreira, artistas portugueses tão socialmente marcantes quanto os nomes das filhas de Nelson e Celeste. O ambiente está definido...

Mas parece-nos igualmente evidente que existe também em Canijo uma atracção incontornável pelo enredo trágico grego antigo, no qual ecoam os mitos mas também os conceitos aristotélicos de hamartia, pathos, katharsis ou os de hybris e moira. Apesar dos elementos modernos, o herói trágico de Canijo é ainda alguém «magnificamente exposto a um esmagador desígnio externo... um erro trágico, capaz de dar início a uma tal acção, no carácter do homem individual.»11

8 Ver Williams 2002: 46-47, 74-75, 140.

9 A. Camus, 1945, apud Williams 2002: 227. Sobre o novo herói trágico, ver ainda Williams 2002: 41.

10 Williams 2002: 145.

11 Williams 2002: 120. 
Em Noite Escura encontramos a lei pseudo-aristotélica das três unidades: há unidade de lugar (um bordel sombrio e lúgubre), de acção (uma dívida por saldar) e de tempo (uma longa e escura noite de Inverno). Eventualmente, não será aqui que encontramos a herança grega propriamente dita, uma vez que esta questão parece ser ela própria mais produto de exegese do trágico do que da tragédia ática ${ }^{12}$. Mas há sem dúvida uma identificação das personagens modernas com as antigas.

Tal como o Agamémnon euripidiano, na sequência de um erro/hamartia, de uma "acçẫo irreparável»" ${ }^{13}$, Nelson vê-se preso a um conflito interior que o coloca perante um dilema praticamente sem solução. $\mathrm{O}$ rei da noite foi longe demais. É hybris. E ao mesmo tempo é um palhaço-conformista, tal como surge na primeira sequência do filme, emblema da sociedade em que se insere ${ }^{14}$. Para ele parece não haver escapatória senão entregar a filha aos homens do Leste, que aliás parecem convocar os antigos Tauros, o povo da Crimeia que acolherá Ifigénia após a intervençáo de tipo deus ex machina com que a tragédia de Eurípides encerra. Tal como Clitemnestra, Celeste ignora o esquema criado pelo marido durante parte significativa da acção, julgando que a sua filha simplesmente irá para Espanha, onde se tornará uma estrela da canção. Também ela, que sintomaticamente acredita no que as cartas lhe dizem, erra ao agir desse modo. Celeste é, no dizer da filha mais velha, «uma mulher com os olhos virados para dentro». Mas é ao aperceber-se do inevitável que a Clitemnestra lusitana coloca ao marido a mais pertinente das perguntas: «Vais sacrificar a tua filha, Nelson?»

De igual modo, ao querer marcar o momento em que a dívida de Nelson será paga, referindo-se a Sónia, Fyodor dirá: «A comida está na mesa!» A metáfora parece-nos adequar-se na perfeição à ideia que associa o festim ao sacrifício antigos. Aliás, tal como o canto da virgem que precede a entrega da mesma e que se faz representar pela estreia artística de Sónia. Ou ainda o colar da meretriz Irka que, qual coroa sacrificial, passa de vítima em vítima, marcando-a como a próxima a ser servida no altar.

A promessa de uma carreira à filha de Nelson e Celeste equivale portanto ao suposto casamento que se deveria celebrar entre Ifigénia e Aquiles. A defesa de Sónia, assumida por Nicolau, parece corresponder à segunda posição de Menelau (note-se a rima dos nomes) na tragédia de Eurípides, assim como a resignação da jovem, ao aceitar ser «oferenda propiciatória»,

\footnotetext{
12 Vide e.g. Forestier 2003.

13 Williams 2002: 81.

14 Cf. Williams 2002: 140.
} 
ecoa a da filha do rei de Micenas/Argos, quando aceita o sacrifício em benefício dos Aqueus ${ }^{15}$. E apesar de a acção de Electra não fazer parte da referida tragédia de Eurípides, é evidente que a sua integração, tal como a de Egisto, é inspirada no papel que cabe a cada uma das personagens nas tragédias do ciclo troiano, como assinalámos. Os caracteres centrais são enquadrados pelo conjunto de prostitutas russas, ucranianas e brasileiras, cujas conversas que encetam com os clientes vamos escutando, quais voyeurs, de forma parcelar e entrecortada. As alternadeiras funcionam como coro alternativo ao das mulheres da Calcídia, em Ifigénia em Áulis. O coro de Canijo, porém, parece alhear-se totalmente do destino de quem as rodeia, coadunando-se com a vontade dos clientes, a quem nada mais interessa senão o desejo básico e a carnalidade, todavia anti-erótica, que procuram naquele lugar. A rotina da carne torna-as indiferentes às desgraças alheias, anestesia-as, como se verifica com o suicídio quase despercebido de uma delas, que todavia intensifica o prenúncio de desgraça. É essa mesma carnalidade, aliás, que o realizador usa para marcar o momento do clímax da tragédia, como que anunciando algo que está para acontecer.

A tragédia de Nelson é marcada pelo dilema para ele insolúvel. A de Celeste pela perda irremediável da filha. A de Sónia pela fatalidade de ser filha de quem é. E a de Carla pela abnegação. Gente vulgar a padecer de tão grandes males. A família Pinto é a família enquanto entidade destrutiva. Homens e mulheres que sofrem e que são destruídos nos seus relacionamentos mais íntimos, no seio do próprio sangue ${ }^{16}$.

Neste filme de João Canijo confirma-se a ideia de R. Williams, para quem «a natureza humana é permanente, universal e essencialmente imutável... Dada esta configuração, a explicação da tragédia tem de ser feita, forçosamente, em termos dessa essência humana imutável ou de algumas das suas faculdades ${ }^{17}$.

Mas a grande inovação de Canijo está, além da transposição para o ambiente do quotidiano de uma casa de alterno, na mudança que se processa no carácter de Carla/Electra. As palavras que Sónia dirige à irmá, quando esta cai com o corpo crivado de balas, antes de entrar no carro em que seguirá para a terra destes «novos Tauros» mostram-no: «Náo roubes a minha morte!» Interagindo com o seu público, Canijo como que pisca o olho ao

15 Tema, aliás, que Aristóteles considerou incoerente e pouco verosímil, Poética $1454 a 35$.

16 Williams 2002: 156, 161.

17 Williams 2002: 69-70. 
espectador, mostrando-lhe agora a sua versão do mito grego: o realizador faz com que a sua Electra morra no lugar da sua Ifigénia, sem que isso, todavia evite o sacrifício da filha mais nova. Apesar da intervenção de Carla/ Electra, a moira de ambas náo deixa de se revelar. Carla tenta alterar o destino mas é mal sucedida. A sua iniciativa de tipo deus ex machina é um desaire, pois essa parte do sagrado está aqui excluída, como afirmámos, o que entra em ruptura com a tragédia antiga, assumindo a idiossincrasia moderna. Mas estará o transcendente aqui de todo excluído? Na verdade, as duas jovens são personagens marcadas pela fatalidade desde o início, pois o destino de ambas está traçado desde que nasceram no seio daquela família. A morte de Carla liberta-a do seu sofrimento, mas náo apaga o da irmá. Mas está claro que Carla é a heroína trágica que não tem saída em vida, podendo contudo afirmar na morte a identidade e a vontade perdidas ${ }^{18}$. Pathos e katharsis entrelaçam-se assim. Nada mais grego, diríamos.

Dentro do bordel, a rotina mantém-se e o quotidiano segue o seu curso. Destas personagens, fica-nos talvez a repulsa ou o desprezo, talvez horror, talvez alguma empatia... Do mythos, nada de moralização ou de denúncia, apenas tragédia...

Noite Escura dá um sentido ainda maior às pertinentes palavras de Raymond Williams: «O que nos espera, no fim do sexo e da feroz e ralada luta pela vida, é a morte.» ${ }^{19}$

18 Williams 2002: 140.

19 Williams 2002: 160. 
Nuno Simóes Rodrigues

\section{Bibliografia:}

Forestier, G. (2003), Passions tragiques et règles classiques: essai sur la tragédie française. Paris: Presses Universitaires de France.

Freud, H. C. (2010), Electra vs Oedipus: The Drama of the Mother-Daughter Relationship. London: Routledge.

Serra, J. P. (2006), Pensar o Trágico. Categorias da Tragédia Grega. Lisboa: Fundação Calouste Gulbenkian/Fundação para a Ciência e Tecnologia.

Williams, R. (2002), Tragédia moderna. São Paulo: Cosac \& Naify. 


\section{O Clássico em Vitorino Nemésio - Uma Leitura de Mau Tempo no Canal segundo as características da Tragédia Grega}

(A Lecture of Vitorino Nemésio's Mau tempo no canal, in accordance with tragic structures)

Paula Barata Dias

Centro de Estudos Clássicos e Humanísticos da Universidade de Coimbra (pabadias@hotmail.com) 
Página deixada propositadamente em branco 
Resumo - Vitorino Nemésio filia-se num sentido de clássico universal, não sujeito às amarras da intertextualidade evidente ou à evocaçáo explícita dos mitos da civilizaçáo greco-romana, ou mesmo a um modelo formal recebido de uma disciplina literária traçada na Antiguidade. Exprimindo-se com ironia, o autor decompóe o termo desde a base, rejeitando o conceito de clássico enquanto estilo artístico que se opõe a outro estilo, ou que é reivindicado enquanto fator de nobilitaçáo para uma obra de que se pretende exaltar o valor. Fixa-se no valor da "permanência da sua significação" no clássico intemporal que decorre da qualidade da obra.

Palavras chave - literatura portuguesa do séc. XX, Açores.

Abstract - Vitorino Nemésio adopts a sense of universal classicism, not creating a true dialogue or a explicit evocation of Greco-Roman myths or models. He expresses himself with irony, rejecting the sense of classicism as an artistic style or as an argument of dignity for some new creation. He stresses his permanence of sense coming from its perfection.

KEYWORDs - Portuguese literature of the twenties, Azores.

Vitorino Nemésio (1901-1978), nascido em 1901 na Praia da Vitória, ilha Terceira dos Açores, é um dos grandes autores literários do séc. XX português, dono de uma obra ímpar, arredia a uma classificação fácil de acordo com as correntes e as escolas literárias dominantes do séc. XX, complexa, na pluralidade dos géneros percorridos, capaz de se reinventar e de surpreender o leitor pelas ruturas assumidas ao longo de uma longeva biografia literária. Nemésio atravessou as geraçóes modernistas, conheceu o psicologismo da Presença e da geração presencista, testemunhou, como criador literário, os influxos tímidos do nouveau roman em Portugal, e caminhou em paralelo com a mais numerosa geraçáo de prosadores do Neo-realismo português. Contudo, de nenhuma destas correntes literárias dos primeiros dois terços do séc. XX português foi seguidor. Vitorino Nemésio é um caso único no panorama literário nacional, pela dificuldade da sua inserção numa corrente estética e literária, pela extensa e complexa obra, em todos os géneros, mas também pela coerência interna da mesma: estamos na presença de um "autor constelação", como o foram Fernando Pessoa, ou Miguel Torga, pois a análise da sua obra resulta não tanto do contexto da sua produção, mas muito mais do posicionamento de cada criação em relação à outra, da continuidade e da evolução entre elas, em suma, da sua leitura e interpretação dentro do universo criativo Nemesiano.

Participante da vida literária e intelectual desde os anos do final da República (1920-26), formou-se em Românicas na Universidade de Lisboa, de que foi professor catedrático até 9 de dezembro de 1971, altura 
em que se jubilou, a dez dias de completar setenta anos. A morte colheu-o aos 78 anos, ainda a ditar versos aos seus filhos, que os iam apontando. O seu desalinhamento em relação às correntes literárias dominantes, associado a uma originalidade intrínseca, feita de escassas ruturas formais quanto à estrutura dos géneros que cultivou, teve certamente consequências na receção da sua obra, que não recebe, quanto a nós, a atenção cuja grandeza suscitaria.

Mau Tempo no Canal é hoje considerado um dos melhores, senão a obra-prima do romance português do séc. $\mathrm{XX}^{1}$. No entanto, o seu reconhecimento foi tardio. Publicado em 1944, o romance teve fraca repercussão entre o público e a crítica da altura. Nos anos setenta, a $2^{a}$ edição da obra pela editora Bertrand contribuiu para a renovação do interesse por esta obra de toada única, desvendando o seu valor e a sua qualidade no panorama das letras nacionais. Maria Lúcia Lepecki, Óscar Lopes, António Machado Pires, José Martins Garcia, e David Mourão Ferreira puderam, entáo alertar para a singularidade do romance Nemesiano.

Como explicar este obnubilar durante quase meio século? Nemésio é um autor constelação mas em que a poesia esmaga e absorve quem por aí inicia o contacto com o autor. Assim, em 1998, vinte anos após a sua morte, realizou-se o Colóquio Internacional de Estudos Nemesianos em Ponta Delgada, sob o acolhimento da Universidade dos Açores e coordenação de um dos seus discípulos e assistentes na Universidade de Lisboa, António Machado Pires, então já professor catedrático da Universidade dos Açores. Oitenta comunicaçôes de estudiosos da sua obra, e contudo, sobre Mau Tempo no Canal apenas oito conferências. Foram entretanto publicadas em 2007 as actas do II congresso dedicado a Nemésio, ocorrido em Salvador da Baía em $2000^{2}$, que não alterou a situação.

Acresce ainda o facto de Vitorino Nemésio, e com maior força de razão a sua obra-prima em romance, MTC, terem sido de algum modo capturados pelo apodo de "autor de forte pulsão regionalista" e de "romance das ilhas", dando corpo a uma classificação literária defendida

1 Vitorino Nemésio (2008) Mau Tempo no Canal, 1944 (1a ed), Relógio d’Água. Citamos esta edição e usamos, doravante, a abreviatura MTC para referirmos a obra no nosso texto.

2 Comemoraçôes 1988; Pires 1988; Hoisel, Ribeiro 2007. 
pela natureza, pela especificidade histórica, social, cultural e política do Arquipélago do Atlântico, que teria marcado as expressôes criativas, estéticas e literárias nascidas nas ilhas - Literatura Açoriana e Açorianidade, em particular o último termo, cujo conceito coube ao próprio Nemésio definir em mais do que uma ocasiāo ${ }^{3}$, e que singrou enquanto conceito operativo na interpretação da obra de Nemésio em estudos recentes ${ }^{4}$. Obra-prima da Literatura Açoriana, considerada sob esse escopo, a ela escaparia o carácter universal das grandes obras, condição que se pode estender a outros escritores portugueses ${ }^{5}$.

Estará MTC cativo da classificação "Literatura Açoriana", versão académica de um conceito interpretativo defensável enquanto modo de defender um particularismo temático e estético, e uma identidade própria para os autores açorianos que situam a sua criação literária no espaço físico ou na mundividência açoriana, captando as particularidades linguísticas e culturais de uma regiāo, muitas vezes a partir já de uma diáspora e de pulverização geográfica assumidas. Mas se esta construção se sobrepuser a uma leitura mais universal de uma obra literária, como entender a poesia de Antero de Quental, ou como enquadrar Raúl Brandão, escritor português nascido no Porto, mas autor de As Ilhas Desconhecidas, obra tão

3 Nemésio 1932: 59. "Como homens, estamos soldados historicamente ao povo de onde viemos e enraizados pelo habitat a uns montes de lava que soltam da própria entranha uma substância que nos penetra. A geografia, para nós, vale outro tanto como a história, e não é debalde que as nossas recordações escritas inserem uns cinquenta por cento de relatos de sismos e enchentes. Como as sereias temos uma dupla natureza: somos de carne e pedra. Os nossos ossos mergulham no mar."

4 Baptista 2012: 17-19. https://repositorioaberto.uab.pt/.

5 Desta limitação padeceram os maiores prosadores da língua portuguesa do séc. XX, como Ferreira de Castro, Aquilino Ribeiro e o próprio Miguel Torga, envolvidos pela cor local dos temas, estilo, vocabulário de um determinado tipo de Portugal que pareciam limitar a grandeza da criação literária a eles associada. São estes autores para quem o manejo da substância literária suprema, que é o homem, se faz cúmplice e dependente de uma terra e de um espaço concretos - o mundo rural e as referências históricas a um certo Portugal - que não são apenas circunstâncias, mas eles próprios condicionadores do desenho das personagens, do enredo, e mesmo da linguagem. 
responsável pela projeção do conceito de insularidade açoriana ainda hoje dominante?

Escutar as palavras que Nemésio proferiu enquanto crítico literário e enquanto poeta torna-se imperioso se quisermos atestar a sensibilidade, ou mesmo a consciência explícita de uma relaçáo, de afinidade ou de afastamento entre si próprio, com o conceito de Clássico.

Em 1938, entáo Diretor da Revista de Portugal, Nemésio publicou uma recensão crítica à obra de Francisco Luiz de Sousa. Neste texto emite o seu entendimento sobre o que tornaria uma obra clássica, situando o texto do recenseado quanto a este valor ${ }^{6}$. Nemésio filia-se a um sentido de clássico universal, não sujeito às amarras da intertextualidade evidente ou à evocação explícita dos mitos da civilizaçáo greco-romana, ou mesmo a um modelo formal recebido de uma disciplina literária traçada na Antiguidade.

6 1938: 99-101 (Cardoso 2005, dissertação de mestrado). Transcrevemos o excerto completo: “ ..."Chamarei clássico ao que se lê em classe? Não digo isto com ar de censura: estabeleço factos a caminho de uma variação sobre o meu conceito de clássico. $\mathrm{O}$ clássico está pois definido como o escritor que foi objeto de classificação. (...) Mas há outra maneira menos primária de tirar o conceito de clássico dos meios oficiais da coisa escrita. É abordar a questão pelo lado dos clássicos e românticos. E clássico e romântico seráo dois modos de morte mutuamente incompatíveis, como classificador de coisas rebeldes, a classe é um modo de vida honesto. Náo quero saber do aspeto formal do classicismo para coisa nenhuma. Todo o apuro verbal que não seja expressão necessária é uma questão de toilette. Por expressão entendo eu que procuro saber que sentido está nas palavras, a própria pressão do que o escritor tem de comunicar, a sua libertaçáo íntima. O estilo, pois, consistia num discurso sem difusão, numeroso, vigiado de vírgulas, denunciante de uma experiência literária rica, tenderá a ser considerado como típico estilo clássico. Foi este o ideal de estilo de todos os tempos. Quer dizer: sempre se ligou à ideia da literatura noções de clareza, precisão e elegância. Mas, por isso mesmo que era um ideal de toda a gente, o deste estilo clássico precisou de desfazer-se em cada personalidade verdadeiramente válida, para se refazer ou se reconstituir segundo as leis dela. (...) Há um classicismo que vem aderido às palavras e às leis por que se agrupam. Esse é o sinal da ordem, de pensamento mais vivo que o sentimento, este recalcado e quanto possível tornado inteligível, esfriado na compreensão, mandado apagar-se para que a evidência seja inteiramente vista. Mas é um classicismo de pouca monta em face do verdadeiro, de que ele é um instrumento, um mero modo. O verdadeiro classicismo é o conjunto de valores que levam o escritor a uma significaçáo permanente. O que dá classe a um escritor é a dificuldade com que se descobriu a sua veia íntima, uma espécie de corda que se retrai, que não vibra senão à tensão máxima e ao mais puro esforço de ajustamento. Mas a essência do clássico ainda é o humano, e para falar de humano são precisas mais páginas do que estas e um ponto de partida mais vivo que o bom Fr. Luís de Sousa. Para clássicos do Humano: Gil Vicente, Camóes, Garrett, Antero e - embora desumanizado pelo abuso do próprio classicismo - Fernando Pessoa". 
Exprimindo-se com ironia, o autor decompóe o termo desde a base, rejeitando o conceito de clássico enquanto estilo artístico que se opóe a outro estilo, ou que é reivindicado enquanto fator de nobilitaçáo para uma obra de que se pretende exaltar o valor. Nemésio fixa-se no valor da "permanência da sua significação" no clássico intemporal que decorre da qualidade da obra:

"O verdadeiro classicismo é o conjunto de valores que levam o escritor a uma significação permanente. O que dá classe a um escritor é a dificuldade com que se descobriu a sua veia íntima, uma espécie de corda que se retrai, que não vibra senão à tensão máxima e ao mais puro esforço de ajustamento."

O "Clássico" pode traduzir-se também na intelectualização do sentimento, que assume uma forma ordenada, clara, esteticamente harmónica, mas este clássico é apenas um instrumento, não é na forma, nem na adoção de um estilo literário que se gera uma obra clássica. Ao enfatizar a "permanência da significaçáo" o clássico de Nemésio é uma atribuição que só o destinatário, na receção, pode conceder.

Noutro apontamento crítico, observamos o distanciamento de Nemésio face a uma receção explícita do património mitológico grego e romano enquanto grande fábrica de histórias referenciais da história cultural ocidental, considerando-a um processo fatalmente mumificado7.

Em duas obras deixou o poeta Nemésio gravada a sua relação com o clássico. As duas composiçóes, separadas por décadas, apresentam grandes semelhanças. A torná-las fundamentais para o assunto que nos ocupa está o facto de as duas serem essencialmente autorretratos. Publicado em 1916, o jovem Nemésio exprime assim a sua "angústia da influência" ${ }^{8}$, depressa subvertendo o seu papel passivo de recetor, para se tornar ele próprio a luz que revitaliza o passado literário:

\footnotetext{
"beijei Homero, e Dante, e Buda, e Prometeu! eu moro no ideal. E Newton e Platáo
}

7 Cardoso 2005: 50 cita Vitorino Nemésio na sua recensão à obra As Mãos e os Frutos de Eugénio de Andrade, 1948: 199: “o mito já agoniza epicamente em Camões, como herdado de Píndaro, morre no Eros de Ronsard. Daí por diante o ocaso do mito é evidente. Com mais ou menos pelo, e sempre com menos sangue - o bode trágico, o anho e o bezerro idílicos vão-se mumificando".

8 Bloom ${ }^{2}$ 1991: 21. 
são os frutos do luar do meu amor loução

[...] eu sou uma centelha, um lampejo divino,

que iluminei o Grego e iluminei o Latino,

Iluminei a Safo, iluminei Virgil'o

E Fídias, e Verdi, e Sófocles e Murillo?.

Neste segundo poema, Nemésio assume-se como um misto de heranças antigas e étnicas, associando-lhes adjetivos que caraterizam genericamente os povos envolvidos. Há uma progressão cronológica ascendente, a que escapam, talvez, as referências à sua identidade enquanto "Cristão só nas conversas"; "Grego no corpo"; "Romano na ambição". Todas estas heranças identitárias, de espaços e de tempos antigos e contemporâneos, fazem do poeta "homem seja onde for". Este é um modo de assumir o denominador comum terenciano, que o libertará para qualquer aventura artística ou estética: é humano, e por isso nada lhe será alheio.
Cruel como os Assírios,
Lânguido como os Persas,
Entre estrelas e círios
Cristão só nas conversas.
Árabe no sossego,
Africano no ardor;
No corpo, Grego, Grego!
Homem seja onde for.
Romano na ambição,
Oriental no ardil,
Latino na paixão,
Europeu por subtil:
Homem sou, homem só
(Pascal: "nem anjo nem bruto")
Cristamente do pó
Me levanto impoluto. ${ }^{10}$

Fomos levados a refletir sobre a estrutura trágica de MTC pela consciência de que a leitura "regional" da obra, apresentada por Lepecki e

\footnotetext{
9 “O Génio", Nemésio 1916: 10.

10 "Retrato", Nemésio 1952: 87.
} 
pela generalidade dos estudiosos Nemesianos era redutora ${ }^{11}$, e que em MTC pulsava uma estrutura que, integrando o contexto e a realidade histórica, social e a mentalidade das ilhas, sofria uma pulsão mais antiga, e partilhada com a grande tradição literária ocidental filiada na herança da tragédia grega.

A leitura de Raymond Williams em Modern Tragedy permitiu-nos este exercício de procurar o trágico em MTC. Neste estudo teórico, reflete-se sobre o sentido comum que, nas sociedades contemporâneas e do discurso corrente, se atribui ao termo "tragédia" como modo particular de classificar um certo tipo de experiências "infortúnio"; "ocorrência infeliz"; e o sentido estrito, específico de um certo tipo de obra literária ${ }^{12}$. Analisa, de seguida, autores modernos, entre dramaturgos e romancistas (Stringberg, Tolstoy, Ionesco, Pasternak) segundo o tema "Literatura Trágica Moderna", mostrando que as características do trágico podem transcender a estrita classificação dos géneros literários como romance e prosa, por um lado; e poesia dramática ou tragédia, por outro. Ordena num capítulo inicial, antes de proceder à análise de vários autores, aquilo a que chama de "Tragic Ideas" 13 , as experiências humanas que, podendo ou náo ser presentes num enquadramento literário, são, em continuidade com a tradição clássica do género trágico, compreendidas na contemporaneidade como "trágicas". Resumimos as ideias principais: "ordem e acidente", acontecimentos arbitrários, dolorosos ou causadores

11 Esta "prisão insular" a envolver MTC foi apontada até pelos melhores conhecedores da obra, que aceitaram a sua condiçáo de romance de um espaço. Vide Lepecki 1971: 44-49. "É difícil encerrar MTC num rótulo. Nele se faz a apresentação, análise crítica de uma realidade social constituída no que se poderia classificar de macrocontexto insulano, e do outro, um micro contexto constituído pelas facçóes económicas e financeiras que se opõem, os Clarks e os Garcias. Para além disso, a própria paisagem dos lugares onde se passa a acção é essencial ao desenvolvimento do romance, visto como há uma especificidade insulana que, em certa medida, envolve e por vezes explica as personagens e os conflitos. Tornam-se essenciais as descriçóes da paisagem física - desde o clima até aos pormenores topográficos - e os estudos psicológicos. Ambos os elementos contribuem para tipificar o ilhéu. Núcleos básicos significativos: a oposição Clarks Dulmos e os Garcias; a miséria do povo face à opulência dos senhores das terras; a estrutura patriarcal da família; finalmente, a problemática pessoal de Margarida, em quem convergem todas as linhas de força do romance."

12 Williams 1966: 15: "Tragedy comes to us, as a word, from a long tradition of European civilization, and it's easy to see this tradition as a continuity in one important way: that so many of the later writers and thinkers have been conscious of the earlier, and have seen themselves as contributing to a common idea of form".

13 Williams 1966: 46-65. 
do sofrimento dos envolvidos, aquilo a que chamaríamos a força dos fados, ou do destino. A ordem, numa tragédia, é o resultado plausível de uma ação. Acidente é o resultado arbitrário. Qualquer deles tem idêntica capacidade de gerar sofrimento. "A destruiçāo do herói": a tragédia, afirma Williams, não é o que acontece ao herói, mas o que atravessa o herói, aquilo que transcende a sua vontade individual, ou capacidade de agir. "A ação irreparável": o caráter definitivo das escolhas feitas pelo homem, no sentido em que cada ação desencadeia o seu irrepetível curso de eventos, constituindo por si um limite ao controlo do indivíduo sobre a realidade. "A ênfase do Mal": afirma o autor que a tragédia nos mostra que o mal é inescapável e irreparável, sendo este um salutar aviso contra as ilusóes otimistas do humanismo. O termo genérico de "mal" reveste muitas formas de fontes de desordem: vingança, ambição, orgulho, ira, ciúme, desobediência, rebelião. A tragédia traduz dramaticamente estes males, convertendo-os em vivências das personagens, enquanto agentes ou pacientes.

Naturalmente, a aproximação entre MTC e o género trágico embate na diferença estrutural dos géneros literários praticados. Na galeria vastíssima de personagens que compóem o romance de Nemésio, na densidade formal da narrativa, na sucessão vertiginosa e simultânea de enredos paralelos que ironicamente se interligam, ou seja, na estrutura profunda de MTC, estamos em crer que Vitorino Nemésio enredou uma ossatura formalmente trágica $^{14}$.

Reler o romance segundo as caraterísticas do género trágico, tal como Aristóteles o expôs na sua Poética pode, por um lado, enriquecer a hermenêutica da obra e por outro constituir um modo alternativo de vislumbrar a apropriação do "Clássico" por um autor que explicitamente parece cético e crítico quanto à sua evocaçáo enquanto exercício cristalizado de identificaçâo face a uma matriz cultural.

A ação de MTC concentra-se num tempo e num espaço limitados para o padrão de um romance: menos de um ano, entre um Novembro de 1918, (cap. I) na cidade da Horta, recebido com os ventos ciclónicos do Outono, e o fim de agosto de 1919 (Epílogo), com o navio S. Miguel a fazer escala na ilha Terceira, e a prosseguir na sua viagem em direção ao Continente, num Exodo que retira do palco os sobreviventes da tragédia, que, tendo remoído

14 Aristóteles, Poética 1447a-1456a. Todas as citações da Poética são as de Valente 2004. 
gerações de famílias antagonizadas, teve o seu clímax nessa estreita faixa de tempo.

A protagonista - Margarida Clark Dulmo, apresenta um desenho eminentemente trágico, tal como Roberto e, em menor grau, João Garcia. É uma jovem de vinte e um anos, vemo-la nesse novembro ventoso em amores proibidos com João Garcia. Sabemos pelo Epílogo que ela teria casado em meados de Maio de 1919, pelo que temos, de facto, um horizonte muito concentrado para a ação dramática. Nesse Prólogo, nada deixa vaticinar que os amores espontâneos entre o jovem casal, espécie de Romeu e Julieta em versão açoriana, terão bom porto ${ }^{15}$.

O romance termina com Margarida desposada, num final formalmente aberto. Apesar da variedade temática da obra e das características estéticas e formais do género narrativo que apontam para a multiplicidade de açóes, o núcleo temático de MTC, embora tal não seja desvelado explicitamente ao leitor, é o casamento de Margarida ${ }^{16}$ : desde a promessa tímida de João Garcia, membro da família rival, nas vésperas da sua partida para Lisboa; passando pela aproximaçáo ao seu jovem tio Roberto, negada pela morte deste; até ao desenlace do casamento com André Barreto, filho dos Baróes da Urzelina, do Faial, que, como um deus ex machina, afasta do palco, não a Margarida do início do romance, mas a sombra cega dela mesma, o que restou após a catástrofe. Os acontecimentos modificaram profundamente as personagens sobreviventes, e, na verdade, o romance é "uma ação completa que forma um todo e tem uma certa extensão"17, a partir da qual há uma mudança de estado "de acordo com o princípio da verosimilhança e da necessidade, a sequência dos acontecimentos, mudando da felicidade para a infelicidade e vice-versa."

$\mathrm{Na}$ leitura das primeiras páginas, percebe-se que a vida amorosa da heroína trágica não é assunto exclusivo de coraçáo, antes está presa a um contexto familiar que a condiciona. Do seu casamento depende a salvação económica e a honra da casta aristocrática a que pertence. Mas nada é fácil. Há um lastro de ódio e de ressentimento sedimentado em vários estratos de

15 Poética 1452 b (definição de prólogo).

16 Poética 1450": "os acontecimentos e o enredo são o objetivo da tragédia e o objetivo é o mais importante de tudo (...) náo poderia haver tragédia sem ação...” (...) sobre a importância do enredo e da estruturação das ações: “....aqueles em que a tragédia exerce maior atração são as partes do enredo...”

17 Poética 1450b, 1451a, 1455b: “toda a tragédia tem um nó e um desenlace. Os factos exteriores à ação e alguns dos que constituem essa ação formam, muitas vezes, o nó, e o resto é o desenlace". 
ofensas, entre a família a que pertence, os Clark Dulmo, e a família burguesa dos Garcias, moradores na cidade da Horta, a que Joáo, o seu inocente amor nestes primeiros capítulos, pertence. $\mathrm{O}$ seu sangue não se misturará com o de uma família burguesa, de antigos empregados, próspera economicamente, mas odiada.

Em todo o romance, emerge a fragilidade conceptual dos patriarcas, herdeiros simbólicos de um património material e de prestígio, a cuja irrisão assistimos. São duas casas em desordem, desgovernadas pela cedência ao imobilismo e à moleza - o caso de Diogo Dulmo; ou por um espírito de vingança e rancor - o caso de Januário Garcia ${ }^{18}$. Estas duas heranças geracionais triturarão, não por linhas direitas, mas por agentes externos (a peste, o fogo) os heróis trágicos, as jovens geraçôes e a esperança de um desenlace feliz ${ }^{19}$.

Este ódio nasceu de uma ofensa ancestral, cujas manifestações do ressentimento acumulado nas personagens se escancaram brutalmente diante do leitor sem que se dê a saber facilmente o ponto de partida do mal, como se, de algum modo, este tivesse sido já substituído pela lembrança, ou pela cristalização do ódio, no correr do tempo. São as personagens secundárias, ou contextos paralelos ao da grande linha narrativa, que vão desvelando a verdade. Januário Garcia, pai de João Garcia, tinha ainda jovem trabalhado como administrador dos negócios dos aristocratas Clark. Pela lealdade e bons serviços nos negócios que julgava prestar, alimentara uma secreta afeição pela entâo criança Catarina Clark, filha do patrão, e que viria a ser a mãe de Margarida Clark Dulmo. Fora despedido com escândalo e envergonhado diante da restrita comunidade burguesa da Horta, graças a uma trama montada por um então jovem Diogo Dulmo, também de família aristocrata e de sangue antigo, como os Clarks. A mão de D. Catarina Clark e o acesso às grossas fortunas dos Clarks, acumuladas pelos ciclos económicos sucessivos: da laranja, do óleo de cetáceo proporcionado pela caça da baleia, dos pastos que alimentavam a criação de gado.

$\mathrm{O}$ ódio enquistado entre as duas castas não é, contudo, a única condicionante na ação de Margarida. Para a aristocracia tradicional, a que a família Clark Dulmo pertence, e para o "dinheiro velho", os tempos esta-

18 Poética 1453a: “...agora, as mais belas tragédias são compostas sobre um reduzido número de famílias”.

19 Poética 1453a: “...é forçoso que um enredo, (...) que a mudança se verifique, não da infelicidade para a ventura, mas, pelo contrário, da prosperidade para a desgraça, e não por um efeito de perversidade, mas de um erro grave..." 
vam a mudar ${ }^{20}$. À decadência de um modo de vida associa-se a dissolução moral: Diogo Dulmo desbaratara, com um comportamento perdulário, toda a fortuna que lhe fora parar às mãos. As propriedades da família iam servindo para amortizar as dívidas contraídas junto de fiadores, e é Januário Garcia, representante do "dinheiro novo", alguém que subira a pulso, com jeito para os negócios, movido pelo rancor e pelo desejo de vingança da humilhação passada, quem vai apertando o garrote aos velhos donos das ilhas, tomando posse das propriedades.

No casamento de Margarida, sendo ela o valor que resta à família Clark Dulmo, repousa a salvação do estatuto da família. Margarida não é ingénua nesta trama e sacrifica o coração à consciência de casta e aos imperativos familiares $^{21}$. João Garcia é filho do arqui-inimigo da sua família, jovem dado a versos e bacharel de direito por Coimbra, bem encaminhado numa vida que o destinaria a alto funcionário nas Ilhas, ou a oficial da marinha. As famílias opóem-se violentamente ao relacionamento entre os dois, embora Januário Garcia, vilmente, conceba um relacionamento que não tem lugar no temperamento sensível do seu filho, nem na altivez de Margarida ${ }^{22}$.

20 MTC regista também partes consequentes da história económica e social do Arquipélago, a viver de ciclos: o ciclo da laranja e das ervas tintureiras para o norte da Europa, que enriquecera os senhores da ilha, começa a ver o seu fim nestas primeiras décadas do séc. $\mathrm{XX}$. A caça à baleia, dominante no séc. XIX e primeiras décadas do séc. XX, vai perdendo relevo com a invenção de compostos de petróleo, que substituem o uso industrial do seu óleo (cf. MTC, XXIII, 273 os efeitos na economia local da decadência da caça à baleia). MTC apresenta esta fase de decadência dos ciclos tradicionais, e a ascensão do ciclo da criação de gado, nas mãos de novos proprietários de ascendência burguesa, "dinheiro novo", os que souberam aproveitar a decadência dos antigos senhores. A paisagem das ilhas torna-se dominada pelas pastagens verdes, cujo sucesso será associado à emigração que assolará as ilhas ao longo do séc. XX.

21 Cap. IX, 99: “...creia que não me queixo de nada, nem mesmo de nos termos falado sem pensarmos no que isso nos podia trazer de desagradável, pois não podemos esperar nada de agradável entre rancores lamentáveis".

22 Cap. XX, 203 "Margarida Dulmo chegara a ser para Januário uma pequena esperança de desforra; mas quê?! Para isso era preciso que João fosse outro homem, que se soubesse aproveitar do escuro dos cedros da quinta, fazer andar o carro à frente dos bois inclusivamente fugindo com ela para o Pico, fazendo rebentar uma escandaleira na Horta [...] a menina fina, a filhinha de seu papá, a elegante da rua do Mar, aparecendo de um dia para o outro de casaco de muita roda, barriga à boca, e ali os vomitozinhos da ordem no balde da madrugada (...) no dia seguinte, o ajuste de contas. Januário fechado com Diogo Dulmo no esconso de uma casa retirada, e as pedras do jogo para ali! Todas as farroncas por terra: "Meu caro senhor: se o meu rapaz se adiantou, é porque o trinco da porta não era de segurança. Quem quer filhas honradas, sopeia-as. "E agora?” Agora só há um remédio: casá-los. Eu livro o senhor das principais enrascadas (credores é cá comigo) e o meu amigo 
Margarida e João afastam-se um do outro, subjugados por uma trama familiar que lhes é superior.

O contexto espacial, o palco dos acontecimentos do romance, pode também merecer uma aproximação aos elementos da tragédia antiga: as ilhas açorianas, tal como surgem no romance, são espaços fechados em si mesmo, lugar em que todos os intervenientes se conhecem, e estão a par das histórias familiares. Os habitantes da Horta, pela voz de personagens secundárias, testemunharam os episódios de ofensas e escândalos entre as duas famílias, sobre eles refletem, avisam, sem alterarem o galope da ação trágica. Estas personagens secundárias no romance, Mateus Dulmo; o farmacêutico Alexandrino; Nina, o camarada de serviço militar de João Garcia; a avó de João Garcia, Maria Florinda; Ângelo Garcia, irmão de Januário Garcia; Manuel Bana; os baleeiros do Pico, alternam entre si a função ora de corifeu, ora de coro, pois assistiram aos eventos, narram-nos em analepses, ou a eles aludem em sentenças crípticas que os protagonistas devem interpretar...é todo um universo social que emerge de uma pólis, em que o destino individual de alguns, nomeadamente o da elite, abala a comunidade.

Tal como na tragédia de Sófocles, Rei Édipo, temos como pano de fundo de todo o romance uma epidemia de peste, que se tornará condicionante fundamental dos acontecimentos. É uma peste que cerca as personagens, aproximando-se insidiosamente. Começara entre os pobres, em S. Jorge ${ }^{23}$.

Nesse serão ainda, antes da falsa certeza de Ângelo Garcia de que a peste era para os pobres, do passado, a terrível doença trouxe para o presente a evocação da mãe de Joáo Garcia, condenada à morte em vida e segregada pela família: D. Emília Faria, esposa de Januário e mãe de João Garcia jazia, talvez com peste, na R. D. Pedro V, da Horta, ali junto do lugar em que jantavam. "Já tenho dito muita vez que essa pessoa, para nós, é como se tivesse morrido!" afirmava um resoluto Januário. Sob uma capciosa acusação de adultério, Januário e Henriqueta haviam expulsado de casa a mãe de Joâo Garcia, era ele menino de nove anos e sua irmã Henriqueta, entâo criança de colo. Emília levava, desde então, uma vida de reclusa, a ponto de

\footnotetext{
dota a pequena com uma parte razoável dos bens que eu, que não sou rancoroso, lhe livro das garras da hipoteca...".

23 Cap. III, 53, ao jantar, Januário lê alto o Jornal: "Na vizinha ilha de S. Jorge têm-se dado ultimamente alguns casos de peste, principalmente na vila da Calheta. O Sr. Dr. Manuel Nunes, digno guarda-mor de Saúde, tomou todas as providências que o caso requeria, não havendo motivo para alarmes. Januário dobrou o Jornal. Esta maldita peste não larga as ilhas! (....). Os pobres morrem como tordos, e, para Ângelo Garcia, irmão de Januário: «- Gente Bruta, que dorme com o curral do porco debaixo do nariz».
} 
nunca mais ter sido vista pelos filhos, João e Carlota. Vítima inocente de uma intriga, morrerá só, tarde demais para recolher o remorso da principal implicada na teia das mentiras, a irmã de Januário, Henriqueta ${ }^{24}$.

Esta, num último assomo, vestira o ancestral capote faialense, que até a tia Secundina, anciã sem idade, classifica de máscara de entrudo (VII, 101: "Estamos no Entrudo! Quem é que recebe máscaras para a menina se pôr nesse preparo?”). Dirigiu-se, anónima e solene, ao lar de Emília, encarando um cadáver abandonado no seu caixão, só pelo receio de contágio, coberto de cal. As palavras da Tia Secundina, associadas à evocação do anacrónico uso do capelo, assinalam a extemporaneidade do arrependimento de Henriqueta, chegado tarde demais.

O filho, João Garcia, será acometido também pelo remorso. Embora toda a família pressentisse a injustiça da acusação (apoiada em cartas comprometedoras de um amante que, lidas à justa, inocentavam D. Emília), numa sociedade em que a aparência e o olhar dos outros se tornam fundamentais para o indivíduo (falaríamos aqui da presença de uma cultura de vergonha ${ }^{25}$ ) não se levantaria a mancha de Emília. Em Lisboa, o militar Joáo Garcia recebia, no mesmo dia, duas cartas, a de Margarida Clark, a romper o namoro. Entrou um camarada de regimento, o Nina, que assiste à abertura da carta do tio Ângelo, a informá-lo da morte da mãe. O tom de Ângelo Garcia também é de contriçãa ${ }^{26}$, assinalando que, com a morte, se dissolvem todas as culpas.

24 Cap. V, 76, "a notícia da doença de Emília não deixara Henriqueta sossegar". Inquieta, refaz a intriga que protagonizara no passado e que condenara Emília à morte social. Durante a sua reflexáo, entrega-se a ferozes limpezas domésticas. Todos estão a par dos eventos trágicos do passado e esperam um ato de misericórdia e reconciliação para com a solitária Emília. O farmacêutico Alexandrino adverte Henriqueta (81) “...A D. Emília, muito mal (...) o tempo faz esquecer muita coisa, e, pelo menos, há obras de misericórdia que mandam perdoar aos que erram (...) Coisas da vida... perdoar aos que erram! Feio mundo!".

25 Dodds 1951: cap. I, II.

26 Cap. VII, 99. “...ninguém escolhe pais para nascer e também não devemos querer mal a quem já lá está à nossa espera e teve a cruz bem pesada (...) tudo o que se passou em casa n'outros tempos náo foi por culpa nossa nem talvez da minha pobre cunhada, são sinas...”. João conserva na memória a violência da expulsão de Emília da casa de família, como empestada em vida, a tia Henriqueta comandando a execução, e a cumplicidade silenciosa do pai que, embora pouco seguro da traição, não toleraria a suspeita e a mancha pública no juízo dos outros; (cap. VII, 102): "Henriqueta que abria a porta, amacacadinha e lívida, com um maço de cartas amarrotadas na mão «-para que a menina não tenha a porca confiança de negar!». Justiceira, atira ainda à pobre mulher: "E diga ao capitão Mota que vai assim toda fresquinha porque enjeitou o leite à filha!...cara sem ponta de vergonha!» João Garcia (lembrava-se disso como da morte!) viu a mãe desatar num choro explosivo 
João Garcia não foi inocente, neste processo: cooperara, com o seu silêncio, no ostracismo a que mãe fora votada, a ponto de não se lembrar como ela era, vivendo a dois passos de si. Sua avó Florinda alertara-o, quando jovem, para a falsidade das acusaçóes contra Emília, mas isso não o levara a agir: (cap. VII, 102) “-o menino respeite sempre o nome de sua mãe, que é tão sozinha no mundo". Ouvindo as confidências emocionadas de João, Nina atira-lhe (100) "Isso é que deve ficar como exemplo na tua vida. Por assim dizer, tens de vingar a tua mãe". João, abalado, diz que nem sabe bem o que significa "minha mãe" posto que não a conheceu... a sua morte reabilitou-a aos seus olhos e é, novamente, Nina que o alerta para o orgulho, para a hybris que comete "atreves-te a condená-la? Reabilitar? Reabilitar o quê?" ${ }^{27}$.

A peste não mais largará a cortina dos acontecimentos no romance. Neste episódio, ninguém, na família Garcia, fora capaz de compreender a falta trágica, o erro primordial, transportando-se este para as geraçóes seguintes, marcando-lhes o destino com o seu rancor. Henriqueta e João puderam escolher e, diante dos acontecimentos extremos, dissolver o erro, mas permaneceram dentro da ordem trágica. O passado semeou, mas é num presente disfórico, condicionado pelas consequências de decisóes erradas, que se colhem os frutos das escolhas e que se desencadeia a catástrofe ${ }^{28}$.

Episódios paralelos, de cegueira trágica face à catástrofe anunciada pela peste que se avizinha, ocorreu com a família Clark Dulmo, que, organizando um passeio à caldeira no centro da Ilha, atravessam a correr, em carros, com medo do contágio, uma paisagem desolada de caminhos de casas queimadas, para travar a disseminação da doença ${ }^{29}$. Enquanto os jovens empreendem o seu irrefletido e aziago passeio, os anciáos do clá discutem, em casa, os maus negócios da poderosa família. Ocorre então um momento catártico de visita a um passado doloroso. $\mathrm{Na}$ casa da família Clark, dá-se

e esmagado, torcendo as mãos para o Cristo amarelo e fumado dos Garcias «Meu Deus, Meu Deus! Eu caia redonda no chão se tive uma pinga de leite para a minha rica menina!».

27 Poética 1453b: "Na tragédia, o sofrimento ocorre entre pessoas de família..." O sofrimento causado pode ser causado com conhecimento ou sem conhecimento das personagens".

28 Williams 1966: 56, "The irreparable Action".

29 Cap. XI, 129. Tarde de Abril, excursão dos jovens da família à caldeira, organizada por Roberto, contra a vontade de Margarida e de Charles, "o Pico de cabeço roxo, cortado de uma nuvem cinzenta. Os carros atravessavam, com medo do contágio, casais atacados pela peste, casais queimados por ordem do delegado de saúde depois de outro foco pneumónico. Mas Roberto insistia que não havia contágio senão ao pé dos doentes ou tocando-se nas roupas infetadas..." 
o concílio dos patriarcas Charles Clark e Mateus Dulmo, respetivamente avô materno e tio-avô paterno de Margarida. Diante do desastre financeiro causado por anos de má gestão e desmandos de Diogo Dulmo, é uma casta, e um modo de vida, que contemplam a sua ruína eminente. Charles Clark lamenta ter sacrificado o seu único filho natural, Roberto, educado à distância em Londres, com a descrição recomendada para os casos de bastardia, aos desvarios da família legítima (Margarida e o indigno genro). Roberto, criado longe da mãe, do pai, e das ilhas, dispóe-se a sacrificar o seu quinhão da herança para salvar da bancarrota o bom nome e o estatuto da família que enjeitara (cap. XI, 131).

Mateus Dulmo desculpava como podia o sobrinho "de má cabeça", mas alerta "há a honra da família em jogo". Charles evoca da memória a falha primordial, fonte de todas as quedas posteriores ${ }^{30}$. Mateus é, de facto, um homem honrado, mas foi cúmplice, com o seu silêncio, da trama que beneficiou o seu sobrinho contra quem germinaria o azedume vingativo de Januário e dos Garcias.

D. Catarina Clark, mãe de Margarida, num transe de Cassandra que todos optam por ignorar, revive o passado traumático que perseguia a família como uma maldição, e trá-lo, como uma ameaça, para o presente indesejado da união dos sangues das duas família, Margarida e João ${ }^{31}$.

30 Cap. XI, 132: "E quem me obrigou, por telegrama, a despedir Januário, e tinha metido no escritório o patife do José Lemos, vosso parente, quando voltei?” Responde o anciáo Mateus: “- Tu carregas demais nas culpas do sangue, Carlos...Que diabo! Somos amigos de infância; eu era como um irmão da tua mulher... Nunca ofendi nem prejudiquei vocês. Sou um homem honrado!”.

31 Cap. XI, 133 “...Tudo isso é obra do Senhor Januário Garcia! Traz isto preparado de longe, na sombra! O pretendente à mão da filha do seu patrão é quase sogro da neta!... que expulsou a mulher de casa para fazer a vontade à irmá, à Garcia” ” (...) ...o baleia! Lembro-me como se fosse hoje! Eu era uma garota de tranças caídas. Aquela ternura, aqueles cuidados! Se chovia, encostava-me muito a si. Eu era uma inocente, nem reparava. Mas depois vinha do colégio a férias, mais pensada... Não! Aquilo não era natural. Fazia-se muito zeloso. Que a casa era muito rica....administrada por ele, era só darem-lhe dois anos, quando houvesse baleeiras a motor. O bola de unto! (...) Deixe-me o pai desabafar! Mas desde que o Diogo me pediu, nunca mais olhou direito para nós. Depois, na ausência do pai, descobriu-se tudo: os lucros que não escriturava; as dívidas fantásticas, sem documentos (...) mão baixa em tudo! Aquelas mãos amarelas, de sapo... aquelas abas: de coruja”. Os dois anciãos tentam calá-la: "-Basta, filha”. Diz Charles. E Mateus, gravemente: “- a D. Catarina esquece-se de quem é...” Ao que ela responde: -"é por me lembrar de quem somos, tio, e a pensar que estive arriscada a ter de chamar genro ao sobrinho da Garcia, ao menino prodígio!...e vamos que o perigo não passou..." 
Charles William Clark menciona a degradação do sangue trazida com o tempo ${ }^{32}$ : É de Mateus, em reflexão interior, que escutamos o contraponto para esta incapacidade de auto-análise de Charles. Ele náo era um santo, nem nos negócios, nem, sobretudo, na vida pessoal. Mateus, assumindo-se no papel de coro, desvela a reclusão a que condenou D. Margarida Terra, sua bela esposa, "a pérola do Faial", isolada de todos na casa do Granel, exibida em festas e remetida para a cristaleira.

A peste atingiu Manuel Bana, o leal e bruto criado de campo e de casa a que ficara reduzido o séquito de serviçais da outrora abastada família. Manuel é sombra protetora de Margarida (cap. XXII). Passada a folia das festas do Espírito Santo no Faial, Roberto, Margarida e Manuel Bana viajaram até ao Pico, com o fim de revitalizar a caça baleeira, pela entrada do jovem André Barreto, filho do Barão da Urzelina, de S. Jorge, na empresa da família. Bastou para que Margarida, a ama, Maria das Angústias, Roberto, ficassem retidos, em isolamento, a acompanharem o doente Manuel Bana. Forçados ao isolamento na Casa da Pedra da Burra, nas Vinhas, propriedade dos Dulmos, é desse lugar em que a morte brinca que discutem o destino dos negócios baleeiros dos Clark Dulmo, desejosos de quebrar o garrote de Januário; é desse lugar que Margarida amadurece a ambição de ir com o tio para Inglaterra, e aí se libertar das teias que lhe cerceiam a liberdade.

É daí também que contemplam o fogo que se ergue no horizonte próximo, na cidade da Horta à distância da travessia do Canal. Fogo e peste são acontecimentos simultâneos, irónicos avisos que a sorte vai lançando, ignorados pelas personagens trágicas. $\mathrm{O}$ fogo consome a casa de Januário. $\mathrm{O}$ incêndio e o rescaldo do desastre decorrem precisamente quando Januário fecha o cerco da humilhação da família Clark Dulmo, forçando o arresto dos barcos baleeiros do Pico ${ }^{33}$. A casa perdida para sempre, a tia Secundina, surda e acamada sem idade, memória da família, lúcida e livre de qualquer

32 Cap. XI, 133-4 "Perdoa, Mateus...mas Dulmos...salva-se o teu pai e salvas-te tu! Mateus expedia a própria vergonha em visôes e nexos rápidos. $\mathrm{O}$ irmão fora jogador e femeeiro. O sobrinho era um bêbado (...) mas o seu querido Charles William Clark não era um santo. Frio, teimoso. Aquela suficiência física de tudo a horas (...) Romanesco com o pai, sem grandes cabeçadas, navegando bem nos negócios desde que o leme andasse noutras mãos”.

33 Cap. XXIV, 240 “....A questão está ganha. A última palavra é nossa. Aí está, na probabilidadezinha certa é que eu jogo a cartada do crédito judicial”. Cap. XXIV, 239: “Todos os meios são bons quando se trata de um fim elevado como este: esmagar esse tratante do Dulmo! O malandro pensava que era só meter a filha à cara do Barreto e trazê-la à perna do tio, que a gente até nem sabe qual dos dois é o editor daquela pouca-vergonha?! Sócios na menina e na baleia, era de mais!". 
convenção social no modo como falava, desfez-se em cinza ${ }^{34}$. No cofre de ferro em que só ele mexia, estava a amorosa fotografia, envolvida de flores, da jovem Catarina Clark, tirada às escondidas quando a transportava na caleche do patrão... apagados estavam pois os vestígios de uma paixão impossível e doentia, que Catarina pressentira e revelara em transe.

É um torturado João Garcia, perdida a casa, a mãe, Margarida, perdidas todas as referências, que lamenta o desenlace trágico desta cadeia de males. Do ponto de vista da economia romanesca, João Garcia é, a partir deste episódio, uma personagem acabada, tolhida pela incapacidade de contrariar as consequências da herança de ódio que seu pai lhe deixara. Este lamento tem pois o sentido de um Êxodo para a tragédia da família Garcia ${ }^{35}$.

Após o incêndio da ilha do Pico, Margarida deixou cair todo o artificialismo da pose recomendada para a sua condiçáo aristocrata: deixa-se arrastar por uma itinerância incomum para uma rapariga da sua condição, numa viagem iniciática, da qual resultam perdas, mas também o conhecimento dos outros e de si: depois de cuidar do seu cuidador Manuel Bana, uma peripé$\mathrm{cia}^{36}$ transforma definitivamente o destino de Roberto e Margarida. Num verdadeiro clímax da ação, dois cachalotes são avistados no Canal, despertando a vocação baleeira das gentes do Pico, saturadas da inação motivada pela ruína financeira dos patróes. Contra a ordem do Juiz, num frenesim predador, fazem-se ao mar ${ }^{37}$. Atravessa o Canal com os baleeiros do Pico, numa perseguição à baleia que servirá de pretexto para salvar a frota da família Clark Dulmo do arresto, deixando o tio à deriva, na lancha, parado no

34 Cap. III, 57 “A surda era uma tia-avó dos Garcias, irmã do "escrivão-velho”. Dizia-se que tinha cem anos; era rija e medonha (...) há mais de dez anos que Secundina se não mexia dali...."

35 Cap. XXIV, 244 "A mim, estragou-me a vida! Contrariou sempre a minha vocação. Fez tudo para me amarrar àquele escritório medonho. Tudo segredos...manobras! (...) Eu perdoo a meu pai o mal que nos fez a nós, difamando a pobrezinha: a ela, a mim, à minha irmã. A Carlota ficou para ali uma triste, sem mocidade, agarradinha às saias da tia Henriqueta (...) eu engulo a vergonha de ver os meus amigos fazerem sinais uns aos outros quando se fala de maus passos. Morreu sem eu a ver, sem poder beijar minha irmã ...desprezada como um por cão! (...) - mas perseguir aquela família com tanto acinte! Tirar-lhe o último bocado...embrulhar-me no mesmo rancor que lhe têm a ele e fazer da nossa vida esta coisa feia, horrível, naquele covil que ardeu ontem sobre as indecências do tio Ângelo!...(...) - É o pai que ma rouba! E eu de quem gosto é dela!"

36 Poética 1452a: "Peripécia é, como ficou dito, a mudança dos acontecimentos para o seu reverso (...) de acordo com o princípio da verosimilhança e da necessidade".

37 O carácter e o destino dos aristocratas das ilhas afetam a comunidade, trazendo desemprego e penúria. Por isso, a perseguição dos cachalotes é um pretexto para esconder em S. Jorge os barcos ameaçados de penhora. É o pão dos baleeiros que está em jogo (Cap. XXIX, 281). 
meio do Canal. Seria esta a última vez que vê Roberto ${ }^{38}$. Arribados a S. Jorge, acompanhada por "homens agigantados, peludos, e apesar de tudo dóceis como meninos, ou pescadores do lago de Tiberíade", Margarida pernoita com eles numa grota. A cena é percebida pelos envolvidos como absurda e irreal ${ }^{39}$.

A peste vitima, por fim, Roberto. Isolada em S. Jorge pelo mar hostil e pela ausência de navios durante quase uma semana, Margarida recebe a hospitalidade dos Barôes da Urzelina, pais de André Barreto. Recebido um telegrama que lhe anunciara ter um tio muito doente, desconhece a identidade do tio que estaria muito doente. Por fim, tarde demais, sabe da morte de Roberto $^{40}$ : a narrativa, em analepse, surgiu pela boca de Manuel Bana, testemunha e mensageiro que, de dentro da sua rudeza sincera, reflete ${ }^{41}$.

Roberto preparava a partida para Inglaterra, ocultando-a de Margarida (Cap. XXXVI, 356). Quando fazia as malas, depara-se com um rato morto, empestado. Manuel ia para queimá-lo, mas Roberto teima em fazê-lo ele mesmo. $\mathrm{Na}$ incineração, saltam, invisíveis, as pulgas. $\mathrm{O}$ episódio náo é apenas fatídico, é profundamente irónico: na curta estada nas ilhas, Roberto entregara-se inconscientemente, por duas vezes, a este convívio próximo com a doença, endémica nas ilhas. Esta proximidade está de acordo com a indecisão de Roberto quanto ao seu destino, quanto ao envolvimento nos problemas da família paterna, na vontade ou náo de se investir do papel salvífico que os Dulmo Clark vêem nele. É quando amadurece a decisão

38 Cap. XXX, 288 "apoderou-se de Margarida uma espécie de íntimo terror, uma impressão de que fora abandonada ao mais apartado de si mesma -àquela zona de imagens, sensaçôes, pensamentos em que o sentimento da própria unidade não conseguia juntar os pedaços doloridos em que se sentia destroçada. E lembrando-se de que fora ela própria cúmplice daquela fuga absurda, se não quem a inventara do primeiro ao último pormenor com uma astúcia diabólica, concebeu um horror quase físico da sua pessoa: do jeito que tinha de levar criados, pescadores, velhas e velhos pitorescos; da sua resistência às provaçôes; da sua atração pelos perigos; de náo haver quilha ou quadrante que a fizesse enjoar".

39 Dizem os baleeiros companheiros da noite a Margarida (Cap. XXX, 296) "Adonde é que vossemecê oiviu dezer quós picarotos havero de varar im Sã Jorge co’ ua cozinheira destas, uma senhora do Faial"; "bota-se de conta que antrou polo telhado lá das vinhas uma feiticeira e deu a menina a uns lambusães" (sc. "lobisomens").

40 Poética 1452a: "Reconhecimento é, como o nome indica, a passagem da ignorância para o conhecimento, para a amizade ou para o ódio entre aqueles que estão destinados à felicidade ou à infelicidade" (...) desse reconhecimento e dessa peripécia depende o ser-se feliz ou infeliz...

41 Cap. XXVI, 357: “quem haverá de dizer qu’o alma do diabo que ua pulga, ua coisa qu' um home esmicha c'ao unha haverá de matar aquele senhor! Entes a peste me tivesse levado a mim! Mas comò oitro que diz, a sorte é cega...”. 
de partir definitivamente para a sua Inglaterra, que a peste, ou as ilhas, cobram o desafio que lhes fora lançado ${ }^{42}$. Roberto recorda-nos, naturalmente, a composição do herói trágico Édipo: rejeitado pela família, para ela é atraído em adulto, com a missão de salvar uma família e toda a comunidade.

Açor, o cão da família Clark, presta-se também a uma leitura enquanto elemento de um enredo trágico: Joáo Garcia, (Cap. I, 31) e Margarida conversam, cada um do seu lado do muro e do seu lado oposto do mundo. Joáo salta o muro para dentro da quinta propriedade dos Clark, e o cão atira-se a ele, obrigando-o a recuar para lá do muro. João Garcia não terá lugar na trama trágica que envolve a família. Teve de recuar para trás do muro. Pelo contrário, o esperado Roberto Clark, filho natural enjeitado de criança para, por fim, entrar na roda aristocrática pela porta grande, consegue aproximar-se de Açor, fazer-lhe festas, encantá-lo. Tal como Édipo, Roberto tem em Açor a sua Esfinge, que o seduz para dentro de uma realidade a que pertencera, de que fora expulso, e a que retorna, para ser consumido pela maldição familiar ${ }^{43}$. Subtil, até, a evocação do incesto, dado o interesse em que "ficasse tudo em família" pelo seu casamento com a sobrinha Margarida. Por fim, é ironicamente devorado por uma realidade de que, conscientemente, decidira, por fim, afastar-se.

Em MTC ocorre também a evocação dos mitos ancestrais, diríamos, os ciclos míticos das ilhas, em que se filiam as famílias nobres e os protagonis$\operatorname{tas}^{44}$. A estrutura compositiva de MTC está assim entretecida com os mitos fundadores da história real ou fantástica dos Açores, ligados à descoberta e colonização, com que as duas famílias, Dulmos e Clarks, se sentem implicados. Temos, por isso, um discurso pontilhado de analepses que fazem recuar profundamente as gerações: Diogo Dulmo, pai de Margarida, é o duodécimo neto de Fernáo Van Hulm, navegador flamengo ao serviço do infante D. Henrique "descobridor de uma suposta ilha ao norte da Terceira, neto do capitão-mor Diogo Dulmo, que hospedou na sua casa o Senhor D. Pedro IV” (Cap. II, 42). História e fantasia cruzam-se, pois não existe nenhuma décima ilha ao norte da Terceira. Mas ficara a memória de que, no séc. XV, a Fernáo Dulmo tinha faltado, por morte de D. Henrique, apoio para uma expedição que confirmaria esta nova descoberta, que seria a Ilha das Sete

42 Poética 1452a 57, definição de "peripécia”.

43 Cap. IX, 113 "Roberto, que fizera o milagre de amansar o Açor falando-lhe grave e de mão bem aberta...”.

44 Poética 1451b: "Na tragédia os poetas prendem-se a nomes reais e a razão disso é que o possível é fácil de acreditar...” 
Cidades. Igualmente maravilhosa é a origem da família Clark na Horta. O trisavô Ralph Clark, navegador e comerciante inglês, tomara-se de amores repentinos por uma freira, filha das melhores famílias do Faial, que raptaria do Convento da Glória, na Horta. Funda-se com sangue estrangeiro, nas ilhas, a linhagem Clark, comerciantes que, estabelecidos em Inglaterra, fazem das ilhas casa-mãe, casulo e cemitério de luxo para as mulheres que encerram em solares, emparedadas vivas, que não acompanham os homens nas suas aventuras por mar e por terras longínquas. De igual modo, o avô Charles Clark desposara D. Margarida Terra, avó de Margarida, da linhagem dos primeiros povoadores de ascendência portuguesa, os Terras.

Esta identificação com a história, os mitos ancestrais e com o religioso não é exclusiva dos abastados. Revivido pelos mais humildes, entranha-se nos comportamentos, justificando condicionamentos atávicos. Veja-se o exemplo do que diz o narrador sobre as festas do Espírito Santo ${ }^{45}$. As festas são vividas numa explosão de alegria quase pagã (sc. a referência aos Floralia), a pomba, símbolo animal do Espírito Santo, evoca o corvo marinho com que o lugar incerto desta Macaronésia era anotado na cartografia maiorquina e veneziana. Este paraíso reencontrado, reino de encontro harmonioso entre homens e Deus, é assim sentido por um paradoxal e comovido Manuel Bana, mordomo nesse ano, que declara solenemente "Imparador do seistimo domingo: Chico Bana!".

Num outro passo emerge o passado mítico das ilhas, com uma história real de extermínio. A natureza vulcânica das ilhas marcou o seu povoamento com um ciclo de aniquilaçóes e de renascimentos para novas eras. Margarida lê, na Casa dos Baróes da Urzelina, em que se acolhera após a arrojada travessia do Canal, na Miscelânea de Garcia de Resende "O Romance que se fez d'alguas mágoas e perdas que causou o tremor de Villa Franca do Campo, em 1522 ", versão poética do cataclismo que pôs fim à primeira capital e mais antiga cidade das ilhas. Soterrada, os sobreviventes cavaram dias a fio para

45 Cap. XVIII, 185: "As festas do Espírito Santo enchem a Primavera das ilhas de um movimento fantástico, como se homens e mulheres, imitando os campos, florissem. Da Páscoa ao Pentecostes e à Santíssima Trindade são sete ou oito semanas de ritos de uma espécie de florália cristã, adaptada a vida da lavoura, dos pastos carregados de humidade e de trevo no meio das escórias de lava (...) o Espírito Santo, aberto numa pomba de prata ao topo de uma coroa real, liga o Pai do Céu aos seus filhos das ilhas dos Açores como a própria ave que marcava nos postulados de Maiorca e de Veneza aquelas paragens mortas: Insula Columbi...Insula de Corvi Marini ...Primaria siue puellarum”. As Festas iniciam-se no Domingo após o Pentecostes, o sexto após a Páscoa. 
recuperar os mortos. Alguns, no meio-termo entre morte e vida "comiam biscoitos de bordo, passageiros da barca de Caronte. Agora, Lázaros vivos".

Trata-se de um motivo recorrente no romance, o da permanência simultânea dos dois estados, morte e vida, ou da morte em vida: Margarida Terra Emília Garcia, Ana Silveira, a mãe de Roberto, a própria tia Secundina "a dever anos à cova". A morte em vida de Margarida, por fim, que sacrifica o amor a João Garcia ao imperativo lançado por Mateus Dulmo "tudo o que fizeres pelos teus é como se o fizesses por ti” (cap. XIII, 154). A ironia trágica revela-se em toda a sua intensidade quando, diante da vida, ou libertação de um destino de "emparedada" ou de destinada ao sacrifício de um casamento de conveniência, que o tio Roberto lhe propóe com a partida para Inglaterra, Margarida escreve a Joâo Garcia, anunciando-se noiva (cap. XIV, 158). Anunciar um casamento sem noivo (neste ponto do romance, André Barreto ou Roberto Clark?) significa libertar-se do amor como motivação principal da sua ação, e, secretamente, colocar no tio a esperança de libertação. Neste caso, ela estaria a anunciar o noivado com Roberto, o esperançoso vivo, prestes a ver a vida ceifada pela peste. Neste sentido, Margarida assume acordes de Antígona sofocleana, a que entoa o seu himeneu a caminho da gruta em que seria emparedada, numa paradoxal evocação desta sobreposiçáo da vida e da morte. Do mesmo modo se aproxima da heroína trágica, ao acompanhar o funeral de Roberto, regressado à sua condição de filho rejeitado, como Polinices.

Além da substância mítica e religiosa que perpassa e condiciona a açáo dos vivos, o espaço dota-se de um significado trágico. Se a tragédia é o género literário da pólis, que questiona o indivíduo na sua interação com o político, com o ético e com o religioso, as ilhas açorianas são aqui tratadas, isoladamente, como um microcosmos, sistema fechado dentro de um universo único, coerente mas fragmentado, no qual a mesma substância humana se movimenta (todos se conhecem), percebendo, em cada passo, o afastamento face ao seu espaço de conforto, diríamos, a sua terra-mãe: as ilhas são o espelho da fragmentação, as dificuldades episódicas e os desencontros motivados pela incapacidade de as personagens principais se deslocarem condicionam os seus destinos; os Faialenses são estrangeiros no Pico, os Picarotos são estrangeiros em S. Jorge, e assim sucessivamente, neste espaço único em que uma ilha, enquanto geografia e enquanto espaço social, se define no confronto, no estar em face da outra.

A dimensão trágica das personagens Margarida, João e Roberto está também presente no facto de, para todos eles, a figura materna ser inexistente ou difusa. Todos são órfãos de mãe, real ou metaforicamente: Margarida recusara o seio materno e o de qualquer mulher, tivera em Manuel Bana a 
figura do seu centauro pedagogo. Roberto, filho de amores inconvenientes entre Charles Clark e uma senhora "fina", fora afastado das ilhas para retirar da vista de todos a prova do escândalo. Crescera desempoeirado por uma educação britânica, entregue com sucesso a uma carreira comercial em Londres. Regressou aos quarenta anos, para abraçar o pai nos seus últimos dias de vida, mas recebe a investidura de salvar, com sangue e dinheiro novos, família e negócios exangues. A ironia trágica fará dele uma vítima: no momento em que escolhe recusar o universo social das ilhas, preparando-se para regressar, subitamente, às ilhas de adoção que o receberam de criança, é contagiado pela peste. $\mathrm{Na}$ hora derradeira, assumiu a sua condição de filho indesejado, e requereu para si, não o jazigo dos Clarks, mas o chão comum do cemitério, onde jazia a mãe que não conhecera.

Margarida está "assinalada" na testa, por uma cicatriz de uma queda de um garrano, feita na infância. Margarida é uma personagem intrépida que, apesar da assunção solene do fardo familiar, tem algo de inumano: em criança, rejeitara todos os seios humanos, tendo sido criada com o leite de uma cabra amarela (Cap. II, 41). Margarida nunca chora, diz dela a mãe (cap. II, 46).

Portadora da "serpente do anel" (Cap. I, 34) que lhe deixara a avó, Margarida Terra recebeu-a já como serpente cega, pois perdera as esmeraldas dos olhos. Quando exibiu o anel a Joáo, e este o beijou, comovido, levantou-se, ominosamente, um ciclone, que obriga o casal a acelerar a despedida daquele encontro fortuito, afinal o último que teriam.

Margarida tem consciência do seu desígnio sacrificial. O primeiro destes atos expiatórios de culpas que náo eram suas, apresentado pelo pai, manchava-se pelo interdito do incesto. Casar com o tio Roberto, o filho natural enjeitado que prosperara em Inglaterra, traria a paz financeira à família. É o pai que a empurra para estes esponsais ${ }^{46}$. Depois de conhecer Roberto, Margarida sentiu-o próximo e estranho à realidade das ilhas. Por isso, viu nele a possibilidade de se evadir das ilhas para Inglaterra, para onde não carregasse o fardo familiar. Num monólogo lúcido, Margarida assume a amargura face ao que esperam dela, mas sobe ao altar sacrificial ${ }^{47}$. As suas oscilaçóes pelos três

46 Cap. IV, 76 "Escuta o pai: o tio Roberto vem aí (...) sim, porque numa hora cai a casa...entendes. Isto e traçava com a máo livre um arco vagabundo que abrangia a mesa, o aparador carregado de pratas, o quarto do velho lá adiante, os tetos, a quinta - é tudo um ar que se lhe dá. Cabeçadas do pai - Teu avô era quase um velho quando o filho nasceu; a mãe não te era nada. Se ele te agrada, deixa...casa! Que fica tudo em família!”

47 Confessa a Roberto (Cap. XIV, 156) “...Numa terra em que tudo são heranças e negócios, o que vale uma rapariga? Se eles já não têm a que se tornem, a gente não lhes pode servir? Sim, é dispor, pois então! Eu sou uma espécie de prédio que por acaso ficou livre. Muito mais 
potenciais pretendentes, João Garcia, Roberto Clark e André Barreto, têm pouco de romântico: desposará o homem que liberte a sua família do sufoco financeiro em que se encontra e o que a tirar do seu destino de emparedada num qualquer solar das ilhas. Por fim, isolada em S. Jorge, Margarida vive a angústia de não saber qual dos seus tios corria risco de vida, e luta com todas as forças para romper a imobilidade a que a condição insular a vota, por falta de um barco que a leve a um destino que, ironicamente, consegue ver diante de si. Regressa ao Faial, por fim, para prestar homenagens fúnebres a Roberto, a sua derradeira esperança de uma vida além do fado das ilhas.

No epílogo, sabemo-la casada com André Barreto, novo sócio dos negócios do pai. Nora dos baróes da Urzelina, Margarida casou dentro da sua estirpe. Esta submissão ao destino, amargamente aceite, é tragicamente assumida no seu gesto final, quando, da amurada do navio em direção ao continente, devolve ao anel de serpente a cegueira que o jovem marido, ingenuamente, julgara dever compor. Metáfora dela mesma, arranca-lhe com violência as esmeraldas dos olhos, porque (Cap. XXXVII, 388) "se sentia cega como a serpente do anel que nenhum ventre de peixe levaria a mesa humana e que àquela hora jazia, como a cucumária dos abismos, no mais secreto mar". Por fim, lança o anel aos abismos profundos do mar açoreano, de onde não voltará, fazendo companhia à sua versão viva das profundezas, a desprovida de olhos cucumaria abyssorum, habitante a milhares de braças.

Neste epílogo, Nemésio faz uso do que entendera ser a sua relação com o clássico: um diálogo vivificador e subtil com a história e os mitos: ao contrário do anel de Polícrates de Heródoto, que voltará às mãos do proprietário, o anel de Margarida nunca se recuperará, pois o mar dos Açores é um mar abissal, ao contrário do Mediterrâneo dos Gregos.

deve um filho «a seus progenitores» (não é assim que se diz?) (...) Já fiz a primeira comunhão; crismaram-me...vamos chegando à altura das flores de laranjeira. A vida é como a roda do ano em casa do lavrador: lavrar, semear, ceifar... Não ouve o que diz a mãe? Esta rapariga não é como as outras, não se sabe divertir! Qualquer dia morro e fica para aí desamparada!”. 


\section{Paula Barata Dias}

\section{Bibliografia}

Aristóteles (2004), Poética. Tradução de Valente, A. M. Lisboa: Fundação Calouste Gulbenkian.

Baptista, J. M. D. (2012), “A açorianidade segundo Vitorino Nemésio”, in Contributos para uma noção de açorianidade literária. Lisboa, Universidade Aberta: 17-19. https://repositorioaberto.uab.pt/.

Bloom, H. ('1973), The anxiety of influence: a theory of poetry. Oxford: Oxford University Press; trad. port. Tamen, M. ( $\left.{ }^{2} 1991\right)$, A Angústia da influência. Lisboa: Gradiva.

Cardoso, M. J. (2005), A Sedução de Prometeu. Nemésio e o Clássico (dissertação de mestrado).

(1988) Comemoraçôes do $10^{\circ}$ aniversário da morte de Vitorino Nemésio. Arquipélago. Linguas e Literaturas 10 .

Dodds, E. R. (1951), The Greeks and the Irrational. Berkeley: University of California Press.

Floisel, E., Ribeiro, M. F. (2007), Vitorino Nemésio e intelectuais portugueses no Brasil. Congresso Internacional de Estudos Nemesianos. Salvador: Direção Regional de Cultura do Governo dos Açores.

Lepecki, M. L. (1971), “Sobre Mau tempo no canal”, Colóquio Letras 4: 44-49.

Nemésio, V. (1916), Poesia. I. Lisboa: INCM.

Nemésio, V. (1932), "O Açoreano e os Açores”, conferência proferida na Associação Académica de Coimbra, 13 de Fevereiro de 1928; "Açorianidade”, Insula, Número Especial Comemorativo do V Centenário do Descobrimento dos Açores 7-8 (Julho-Agosto). Ponta Delgada.

Nemésio, V. (1938), "Um conceito de clássico. A propósito do I volume dos Anais de D. João III de Francisco Luiz de Sousa, ed. Rodrigues Lapa, col. Sá da Costa”, Revista de Portugal 5. 1: 99-101.

Nemésio, V. (1952), Nem toda a noite a vida. Lisboa: Ática.

Nemésio, V. (2008 reimpr.), Mau Tempo no Canal. Lisboa: Relógio d’Água.

Pires, A. M. et al. (eds.) (1998), Vitorino Nemésio, Vinte anos depois. O Colóquio Internacional. Lisboa / Ponta Delgada: Edições Cosmos.

Williams, R. (1966), Modern Tragedy, London: Encore Editions. 


\title{
A Phýsis Grega e o Brasil: as viagens de Von Martius
}

(Greek physis in Brazil: the travels of Von Martius)

\author{
Alexandre Schmitt \\ Universidade Federal do Rio de Janeiro \\ (alexandre.schmitt01@gmail.com)
}


Página deixada propositadamente em branco 
Resumo - O objetivo deste artigo é investigar as referências ao universo clássico em algumas passagens das Tabulae Physiognomicae de Flora Brasiliensis, em especial, nas passagens existentes nas pranchas I, II, VI, VII, VIII e IX, visando a uma compreensão dos objetivos de Carl von Martius na utilização desse artifício para a descrição das paisagens brasileiras apresentadas nessas pranchas.

Palavras-chave - Flora Brasiliensis. Von Martius. Phýsis.

Aвstract - The objective of this paper is to investigate the references to the classical universe in some passages of Flora Brasiliensis' Tabulae Physiognomicae in particular the passages on boards I, II, VI, VII, VIII and IX, aiming to understand the objectives of Carl von Martius' use of this device for the description of the Brazilian landscapes presented in these boards.

Keywords - Flora Brasiliensis. Von Martius. Phýsis.

\section{Introdução}

No ano de 1815, a Real Academia de Ciências de Munique começa a organizar, por ordens do rei Maximiliano José I da Baviera, uma expedição científica para desbravar o interior da América do Sul. A intenção inicial era que ela desembarcasse em Buenos Aires, cruzasse os Andes e seguisse ao norte, em direção ao Equador ou à Venezuela, sendo comandada por Johann Baptist von Spix, zoólogo, e integrada também por Carl Friedrich von Martius, botânico, ambos membros da Academia muniquense. A expedição, contudo, sofre um atraso, que acaba sendo decisivo na determinação dos rumos que ela veio a tomar. Em breve, na Áustria, país comandado pelo genro de Maximiliano José I, Francisco I, iniciar-se-iam os preparativos para a viagem de sua filha, Leopoldina, para o Brasil, em virtude de seu casamento com Pedro. O Museu de História Natural de Viena preparava, então, uma expedição científica em direção ao interior do Brasil e Maximiliano José I, que tinha ótimas relaçóes com Francisco I, conseguiu que os seus naturalistas bávaros a integrassem.

A expedição chega ao porto do Rio de Janeiro em julho de 1817. Spix e Martius permanecem seis meses na cidade onde organizam o roteiro de sua viagem, decidindo, então, ao final desse prazo, partir sem os demais integrantes austríacos da expedição, visto que esses faziam parte da comitiva de Dona Leopoldina cuja vinda para o Brasil sofrera um grande atraso.

A expedição dos bávaros passou pela província de São Paulo, por Minas Gerais e rumou para o norte do país, cruzando todo o sertão nordestino e adentrando a Amazônia por meio do rio Amazonas e do Solimóes. Finalmente, em abril de 1820, os dois naturalistas partem de Belém de 
volta para Munique, onde seus relatos de viagem e a fabulosa coleção de espécimes botânicas, de animais e de artefatos minerais e etnográficos por eles coletados será organizada. Em 1823, é editado o primeiro volume de Reise in Brasilien - Viagem pelo Brasil, obra que será finalmente completada com a publicação de seu terceiro e último volume em 1831, já sem a colaboração de Spix, que falecera em 1826. Simultaneamente à edição dos seus relatos de viagem, Spix e Martius publicarão também o resultado das suas investigaçóes botânicas e zoológicas. No mesmo período, entre 1823 e 1831, três volumes da Nova Genera et Species Plantarum Brasiliensium serão publicados por Martius e, em 1840, depois de uma tentativa fracassada de publicação ocorrida em 1833, será editado o primeiro fascículo de Flora Brasiliensis, patrocinado por Fernando I, imperador austríaco, e pelo rei da Baviera, Ludovico I. Após a abdicação do soberano bávaro, a obra, a partir de 1850, passará a ser financiada por Pedro II do Brasil, tendo a sua publicação na íntegra sido completada apenas em 1906, sessenta e seis anos, portanto, após a publicação do primeiro fascículo. Martius falece em 1868, completando 46 fascículos, assumindo, então, a coordenação da edição, August W. Eichler e, posteriormente, Ignatz Urban. Serão ao todo 130 fascículos, com 20.733 páginas, que depois serão reorganizados em 40 volumes, constituindo a maior obra já publicada sobre a flora de um país ${ }^{1}$.

O primeiro volume é dividido em seis partes, sendo a primeira delas as Tabulae Physiognomicae Explicatae. As Tabulae Physiognomicae Explicatae compreendem descriçóes de cinquenta e nove pranchas litografadas, apresentando a vegetaçáo e o ecossistema brasileiros, além do primeiro ensaio publicado sobre a fitogeografia do Brasil. Martius propóe uma divisão do território brasileiro em cinco zonas fitogeográficas: Náiades (que corresponde à Floresta Amazônica); Hamadríades (a caatinga); Oréades (as montanhas e o cerrado do Planalto Central); Dríades (a Floresta Atlântica) e Napeias (as matas de Araucária e os Pampas). Essa divisão consta de um dos mapas que integram esse primeiro volume. Portanto, a úmida floresta amazônica é denominada segundo a ninfa das fontes e córregos do universo mitológico grego; a Caatinga é o espaço das ninfas das demais árvores; a Floresta Atlântica constitui a terra das ninfas associadas aos carvalhos; o Planalto Central e as montanhas, o espaço das ninfas protetoras das montanhas; e os Pampas e as Araucárias do sul do Brasil, a terra das ninfas asso-

1 Para uma descrição detalhada de todos os aspectos históricos da viagem e da produção científica de Martius, ver Lisboa: 1997. 
ciadas a vales, colinas e depressóes. O espaço fitogeográfico brasileiro, desse modo, é descrito com referência a elementos do universo mitológico grego.

Essa é apenas uma das inúmeras referências que são feitas nas Tabulae Physiognomicae ao universo literário clássico. Além delas, concepçôes gregas acerca da phýsis são também frequentemente evocadas para descrever as paisagens brasileiras. O objetivo deste artigo é investigar as referências ao universo clássico em algumas passagens das Tabulae Physiognomicae, em especial nas passagens existentes nas pranchas I, II, VI, VII, VIII e IX, visando a uma compreensão dos objetivos de Martius na utilização desse artifício para a descrição das paisagens brasileiras apresentadas nessas pranchas.

Para tanto, inicialmente se discorrerá sobre o contexto histórico-cultural da expedição de Martius e da elaboração do seu Flora Brasiliensis, dando-se destaque à concepção de natureza ali existente. Depois disso, serão comentadas as passagens nas pranchas acima enumeradas que fazem referência ao universo clássico.

\section{O contexto histórico-cultural}

As descriçóes apresentadas por Martius nas Tabulae Physiognomicae apresentam uma concepção organicista da natureza, marca do romantismo alemão, em contraposição a uma visão anterior, notavelmente mecanicista. Há, inclusive, certo holismo e certo panteísmo na descriçâo do viajante, e mesmo, certo vitalismo como se pode notar em algumas passagens que serão elencadas neste trabalho.

Para que se possa compreender o porquê de uma postura não meramente taxonômica da paisagem, mas o uso de uma abordagem verdadeiramente poética para dela tratar, é fundamental que seja exposto o contexto histórico-cultural em que foi fomentada a obra de Martius. Ganham destaque especial: a) o estilo estético-científico proposto por Alexander von Humboldt na descrição dos seus relatos de viagem; b) a Naturphilosophie - filosofia da natureza - de Schelling; e c) a influência do pensamento de Goethe.

A importância do estilo estético-científico de Alexander von Humboldt ${ }^{2}$ na elaboração do estilo narrativo de Martius é atestada por inúmeros au-

2 Note-se que Martius faz na prancha XXVIII das Tabulae Physiognomicae da Flora Brasiliensis uma referência elogiosa a Humboldt: "Aquele ilustríssimo viajante do mundo e também seu retratista, Alexander von Humboldt, a quem devemos como que os fundamentos da fisionomia das plantas, entre muitas outras coisas, na obra (Ansichten der Natur, 1808: 322) diz que era essa a índole dos primeiros tempos das florestas primitivas, que apareçam impenetráveis, [...]”. Ver Martius 1996: 97. 
tores. Humboldt estivera em inúmeras expediçóes na América Latina entre 1799 e 1804. Em 1807, ele publica Ansichten der Natur - Quadros da Natureza, e, no prefácio à sua primeira edição, ele explicita não só o objetivo de sua obra, como também o estilo e o método que adota para a sua elaboração:

A visão da Natureza em uma escala amplificada, a exposição da ação concorrente de várias forças ou poderes, e a renovação do prazer que a perspectiva imediata [da cena tropical] proporciona às mentes sensíveis são os objetivos que eu propus a mim mesmo. Embora cada um dos tratados [de que a minha obra consiste] deva formar um todo completo em si mesmo, uma tendência comum deve permear a todos. Esse tratamento estético dos objetos da história natural está sujeito a grandes dificuldades de composição, não obstante o poder e a flexibilidade da nossa língua materna. [...] Quando os sentimentos e a imaginação falam mais alto, o estilo se degenera em uma leve prosa poética. Mas eu não preciso aqui descrever de forma mais completa os perigos que eu temo que as páginas seguintes mostraráo que eu nem sempre consegui evitar. Contudo, não obstante as falhas que eu posso mais facilmente perceber do que evitar, eu espero proporcionar ao leitor uma porçáo daquele prazer que a mente sensível recebe da contemplação imediata da natureza. [...] Ao longo de todo o trabalho, eu apontei a infalível influência que a natureza física exerce sobre o sentimento moral da humanidade e sobre o seu destino. Essas páginas são dedicadas preferencialmente às mentes atormentadas ${ }^{3}$.

Em outras palavras, Humboldt ao mesmo tempo em que defende uma utilização minuciosa de aparatos científicos para descrever a natureza, visando a desvendar o conjunto de forças que harmonicamente a constituem, preconiza um tratamento estético de seus textos, de forma a gerar no leitor uma espécie de prazer que a contemplação física da natureza proporciona. O seu relato assume, nessas situações, o caráter de uma espécie de prosa poética. Trata-se, portanto, de uma fusão entre ciência e poesia, uma espécie de mescla entre o empirismo baconiano e a filosofia da natureza de Goethe e de Schelling ${ }^{4}$. Ecos de Rousseau são perfeitamente audíveis nessa forma narrativa, que carrega consigo e, mesmo constitui, uma verdadeira

\footnotetext{
3 Humboldt 1808: v-viii. Tradução nossa.

4 Ver Vitte 2006: 40.
} 
filosofia da natureza. É, aliás, como uma espécie de filosofia da natureza que Humboldt descreve o seu próprio trabalho:

[...] a filosofia da natureza se desprende das formas vagas e poéticas próprias de sua origem, adota um caráter mais severo, inclui o valor das observaçóes e já não se entrega à adivinhação como antes, e nem à relação e ao raciocínio5.

Essa postura de Humboldt aponta para uma espécie de síntese de ideias da ilustração e de ideais românticos ${ }^{6}$. Assim, se o iluminismo é marcado por uma perspectiva mecânica do mundo, derivada das descobertas newtonianas, e por uma crença na razão como meio de compreensão da realidade e na criação de um mundo justo, o romantismo será fruto justamente de uma crise do primeiro, diante da falência da promessa de alcance dos ideais de igualdade, fraternidade e liberdade. A sociedade é vista como injusta e opressora e o indivíduo é redescoberto como figura primordial, ressaltando-se o seu "mundo interior", constituindo o "mundo externo", em grande parte, apenas uma extensão do primeiro. A natureza será vista então como o elemento que proporciona a liberdade de que o homem precisa, elemento que o consola das tormentas da existência, "uma grande rede viva de relações, um grande "eu"" "' "um organismo capaz de desenvolver criativamente suas potencialidades inerentes, ao longo do tempo"

Ela será vista como uma unidade harmônica e o resultado mais importante do seu estudo racional será a compreensão do imenso agregado de coisas e de forças que se relacionam e geram essa harmonia'.

Se Humboldt constitui uma influência essencial para a confecção do estilo de Martius, Goethe não representa uma influência menor. Martius e Goethe se correspondiam com frequência. Em setembro de 1824, um contato pessoal é estabelecido por ambos ${ }^{10}$. Nasce assim um intercâmbio científico e cultural dos mais fecundos, o qual se enraíza especialmente nas concepçóes panteístas de que partilhavam o velho poeta de Weimar e o jovem botânico. A relação entre Goethe e Martius gerará uma influência

\footnotetext{
5 Humboldt 2005: 18-19. Tradução nossa.

6 Ver Springer 2009: 11.

7 Springer 2009: 10.

8 Springer 2009: 10.

9 Ver Humboldt 2005: 19. Tradução nossa.

10 Ver Mazzari 2010: 184 e Lisboa 1997: 74-75.
} 
mútua tanto na obra do primeiro quanto na do segundo. Goethe leu e releu a Flora Brasiliensis de Martius até o fim de sua vida, e uma teoria de Martius sobre a tendência espiral das plantas gerará um certo entusiasmo nele, sendo peça importante na elaboração do Fausto $\mathrm{II}^{11}$. Quanto a Martius, esse leva consigo para a sua expedição o Fausto e o relê constantemente ${ }^{12}$. Além disso, A Metamorfose das Plantas também é outra leitura frequente, como ele mesmo atesta em uma carta a Goethe em que enviava ao mestre de Weimar a primeira parte de seu tratado Palmae Brasiliensis ${ }^{13}$.

Dois outros pontos da relação entre Martius e Goethe merecem ainda atenção ${ }^{14}$ : Martius e o botânico Nees von Esenbeck dão o nome de Goethea a um tipo de malvácia endêmica no Brasil e Goethe fica muito feliz e envaidecido com isso; e Goethe saudará Martius, quando da sua estada em Weimar, com um dístico com uma tendência nitidamente panteísta: "Was hiesse wohl di Natur ergründen? Gott ebenso draussen wie innen finden" ("O que significa entáo perscrutar a Natureza? Encontrar Deus tanto fora como dentro de si" $)^{15}$. Espinosa fora uma importante influência na concepção do pensamento de Goethe e, curiosamente, também na concepção do pensamento de Martius ${ }^{16}$ : em maio de 1825 ele dirá em carta a Goethe que nada o preparara tanto para a viagem brasileira como o pensamento de Espinosa e a leitura do Fausto ${ }^{17}$. Para Goethe, a Natureza é Deus. Em outras palavras, ela é uma das infinitas dimensóes do ser de Deus e dos atributos externos do Divino.

11 Sobre a influência mútua dos dois autores, ver Mazzari 2010: 185-195.

12 Ver Lisboa 1997: 74.

13 Ver Mazzari 2010: 191. Nesse texto, Goethe relata a sua doutrina, segundo a qual todos os órgãos de uma planta constituem formas de folhas transformadas. Essa ideia deriva do conceito de Urphänomen do próprio Goethe - fenômeno originário, segundo o qual haveria uma forma originária a partir da qual todas as plantas (e todos os animais) haviam se originado. Era uma espécie de forma primeva.

14 Ver Mazzari 2010: 186.

15 Ver Mazzari 2010: 186.

16 A referência e o elogio a Goethe aparecem também nas Tabulae Physiognomicae de Flora Brasiliensis. Na prancha XXIII, Martius cita: "A esta singular e quase hórrida espécie de natureza enquadra-se o que disse o nosso maior poeta, Goethe, cuja antiga familiaridade estará sempre entre os maiores presentes do destino: Mas porém quem é ele?/ Entre os arbustos perde-se o seu rastro,/ Atrás dele fecham-se/ Os arbustos/ As hastes da grama erguem-se novamente/O vazio o engole!". Ver Martius 1996: 88.

17 Ver Mazzari 2010: 186. 
Em uma carta de 18 de maio de 1825, Martius esclarece, sobre a sua concepção de natureza, que o que importa é perceber

[...] o espírito da natureza, que justamente não pode ser guarnecido por diagnóstico algum. Mas ele está vivo e presente, eternamente solicitando a mente humana, atraindo e rejeitando-a; trata-se de um grande jogo, que seria terrível, se não se pudesse crer que não finda com a morte, e sim que se perpetua nos éons cada vez mais encantado, enobrecido e apoteosado ${ }^{18}$.

Ou seja, Martius parece deixar claro que, mais do que fazer taxonomias e classificaçóes, ele tem em mente não só uma concepção de unidade da natureza, mas vê nela uma certa expressão de um espírito eterno. Isso remete diretamente à filosofia da natureza de Schelling.

Spix conhecera Schelling em Würzburg, onde estudara teologia em um seminário episcopal, após doutorar-se em filosofia na universidade de Bamberg. Será o próprio Schelling que, anos mais tarde, após tomar posse como membro da Real Academia de Ciências de Munique e dirigir a Academia de Artes, indicará o nome de Spix ao ministro de Estado, para um financiamento de uma viagem de estudos à França, à Itália e à Suíça ${ }^{19}$.

Schelling se opóe a uma visão mecanicista da natureza, propondo uma visão holística. Para ele, os fenômenos naturais seriam a manifestação de uma mesma atividade, uma espécie de força. Caberia à filosofia da natureza explicar como uma atividade absoluta e infinita se apresenta empiricamente no finito. A filosofia da natureza deveria, desse modo, começar pela pesquisa empírica, pois a identificaçáo pura e simples da atividade absoluta não basta. Em Da alma no mundo, ele tenta mostrar como a natureza se desdobra de forma individual como um impulso universal para uma organização. Nesse contexto, o naturalista desempenha um papel importante. A Naturphilosophie, portanto, não implica uma ignorância dos dados individuais oriundos da pesquisas empíricas, mas, muito pelo contrário, deve procurar sintetizar esses dados. Em outras palavras, "para mostrar como a natureza opera em escala universal, deve-se primeiro ver como ela opera no mundo concreto e tangível"20.

\footnotetext{
18 Martius apud Lisboa 1997: 75.

19 Sobre a relação de Spix e Schelling, vide Lisboa 1997: 52-53.

20 Foster 2008: 275.
} 


\section{A Phýsis grega nas Tabulae Physiognomicae}

Um levantamento das referências diretas ao universo clássico nas Tabulae Physiognomicae atesta a ocorrência de passagens nas seguintes pranchas: I, II, VI, VII, VIII, IX, X, XII, XIII, XVI, XXIV, XXIX, XXX, XL, XLI. Referências indiretas podem também ser encontradas em outras pranchas.

$\mathrm{Na}$ primeira prancha, Martius justifica o motivo de ter denominado as plantas da floresta Amazônica de Náiades. Segundo ele, a umidade da regiấo é muito alta e isso se deve principalmente às próprias plantas e às chuvas frequentes. Ele então afirma que "Netuno lhes é favorável" 21 . A intenção de Martius aqui parece ser meramente estética. Mas isso não é tudo. Se, na concepção cartesiana, só os seres humanos apresentam uma alma racional, e os animais e vegetais têm apenas uma alma sensitiva, para os românticos em geral, a natureza é plena de espíritos. A menção a Netuno, e mesmo a divisão da paisagem brasileira em reinos de diversas ninfas, é, sem sombra de dúvidas, também uma forma de se fazer referência ao caráter divino atribuído a ela em geral pelos autores românticos. Esse aspecto, como visto acima, está presente, de facetas variadas, tanto na filosofia de Schelling quando no pensamento de Goethe. As referências às ninfas e ao deus Netuno possivelmente também fazem parte de uma estratégia de antropomorfização da paisagem, em uma tentativa de despertar, por meio da reaçáo do leitor a essas metáforas, sentimentos e emoçôes de temor ou de amor que são mais facilmente despertados por um ser humano diante de outro ser humano.

$\mathrm{Na}$ segunda prancha, a referência ao universo clássico não é explícita. O texto original menciona a possibilidade de um botânico se deparar com pítons e crocodilos. Se os termos forem traduzidos literalmente, em vez de serem traduzidos de forma mais genérica por cobras e jacarés, não se trataria de animais passíveis de serem encontrados no Brasil, podendo ser, como assinalam os tradutores da edição brasileira da Flora Brasiliensi ${ }^{22}$, uma possível referência metafórica ao píton mitológico, à serpente ou ao dragão morto por Apolo na cidade de Delfos. A referência aqui, mesmo nesse caso, se houver, parece ter motivação eminentemente estética.

Na prancha seis, sobressaem as referências a Plínio, a Sêneca e a Lucrécio. Aqui elas assumem um caráter menos estético e mais filosófico, visando a despertar o leitor para o jogo de forças harmônico que constitui a natureza, lembrando a filosofia da natureza de Schelling. Também é ressaltado o

\footnotetext{
21 Martius 1996: 24.

22 Vide Martius 1996: 26 n. 1.
} 
caráter eterno da natureza. A analogia que é feita entre os túmulos de um cemitério e as plantas mortas em uma floresta constitui uma referência direta à ideia de imortalidade da alma.

Se quem entra num cemitério mal cuidado vê túmulos espalhados, sem flores, diligentemente plantadas ao seu redor e sem piedosos tufos de plantas que os cubram, misturando-se diante de seus olhos a terra nua, as pedras soltas e os pútridos ossos dos mortos mal escondidos, será tomado por horror e aversão. Longe estará, portanto, daquele outro estado de espírito, onde serenas imagens da morte são como imagens da vida que a virtude e a indulgência dos vivos derramaram sobre elas. $\mathrm{O}$ mesmo acontece na floresta. Por ventura não é ela mesma um cemitério, onde a vida de cada um, depois de ter florescido por um instante, recebe o abraço comum da morte? Além disso, não ignoramos que a ruína da geração precedente e sua passagem para o chão preparam sobretudo o lugar para uma nova disposição das coisas: quem aparece mais rápido também mais rápido se liga ao desenvolvimento de outro mais forte, assimilando-se a ele. Com isso extingue-se de todo o quadro a imagem da morte e da destruição de cada um, o que constringe o sentimento humano e de um certo modo entristece. Aqui vemos confirmadas as palavras de Sêneca: Diz-se que a natureza nada perde, porque aquilo que é tirado dela, a ela retorna; e coisa alguma pode ser destruída, porque náo tendo para onde ser levada, se volve sobre si mesma onde não deveria estar. De maneira semelhante diz o grande poeta Lucrécio:

Tudo o que retoma para seus corpos

A natureza dissolve sem destruir coisa alguma

Por isso nada parece totalmente acabar:

Quando a natureza faz de alguma coisa nascer outra

Deixa que o que nasce traga em si a morte alheia. ${ }^{23}$

Ao final da mesma prancha, o papel atribuído ao naturalista por Schelling, de coletar dados particulares para que a partir deles uma intuição acerca do funcionamento do todo possa surgir, parece sobressair.

23 Martius 1996: 35. 
Se contemplarmos a ordem natural desta sucessão de plantas descobrimos que existe algo de agradável que atrai e encanta o nosso espírito. $\mathrm{Na}$ verdade aprendemos aqui como uma grande quantidade de plantas diversas começa e acaba a vida, de acordo com a sua própria natureza, e como todos esses desdobramentos naturais estáo relacionados entre si e regidos por alguma lei maior. Esta lei sabe o que seja presente, passado e futuro. Ela não corresponde a uma necessidade cega da natureza, mas considera as condiçóes particulares que afetam inteiramente a vegetação, os períodos de seca e a umidade que as raízes absorvem e encaminham para a copa, pois mais cedo ou mais tarde as plantas hão de amadurecer e produzir seus frutos. Estáo reunidas as duas coisas, o que é próprio da natureza mesma da vegetação - e a alma a quem o criador dos mundos determinou que ligasse o movimento da vida terrestre à prosperidade das plantas e que assim um e outro, a vegetaçấo e a vida do planeta, se completassem. Seja-nos permitido lembrar as palavras de Sêneca: "A terra não conseguiria sustentar tantas e tâo grandes coisas, e inclusive a si mesma, se não estivesse cheia dessa alma que dia e noite se funde a todas as suas partes"24.

De nenhum modo me escapa que mesmo sendo tantas as mudanças e atividades no grande teatro da natureza elas possam ser inteiramente contempladas, ainda que estejam submetidas a leis intimamente relacionadas. É como o movimento de um relógio em que todas as peças obedecem a uma mesma lei física e em que todos os movimentos podem ser compreendidos por uma única apreensão da mente humana. Mas para mim esse ritmo de movimentos e mudanças que também se encontra em várias formas de plantas, parece depender de leis muito mais sutis e não propriamente desses mecanismos. Estes seres vivos, que concorrem aqui para um sistema táo maravilhosamente ordenado, trabalham segundo um mesmo princípio. Tudo isto acontece dentro dos amplos limites da atividade da vida orgânica que, pelo curso natural de cada coisa, permitem que haja algumas perturbaçóes e deformaçôes, origem daquelas mudanças que a natureza supera, combina e adapta. Eu não censuraria quem visse aqui aquela ideia de Platáo (no Timeu) segundo a qual o demiurgo determinou que representantes seus considerassem, para certas atividades orgânicas ligadas ao desenvolvimento do mundo, as açôes de cada coisa, ordenando-as e combi-

24 Martius 1996: 37-38. 
nando este mundo harmonioso desde o nascimento do indivíduo até o seu apogeu e daí até ao seu fim² ${ }^{25}$.

A crítica ao mecanicismo newtoniano e ao pensamento cartesiano fica evidente no trecho acima. Aqui claramente insinua-se a ideia da existência de uma força vital e uma perspectiva provavelmente teleológica da natureza, em contraposição à perspectiva causal-mecanicista cartesiana. Note-se também que a natureza é equiparada a um teatro, como se o que fosse observado fosse só, possivelmente, uma aparência, um lado externo da máscara do mundo, que, ao mesmo tempo que o oculta, o revela.

$\mathrm{Na}$ prancha sete, por sua vez, a natureza no Brasil é descrita como o Elísio humano.

Se é justo afirmar que o Brasil é uma das mais belas regióes do mundo, ao mesmo tempo deve-se dizer que é assim porque lá a natureza oferece à nossa vista diversíssimos e quase que opostos aspectos de beleza. A imensa quantidade de coisas, a inesgotável fecundidade da vegetaçáo, o extraordinário esplendor do céu que por toda parte favorece a vida humana, a encantadora formosura que se vê nos horizontes amenos, no perfil das montanhas, na distribuição das águas e dos rios, tudo isto não poderia produzir aquela terra belíssima, ou o elísio humano, como podemos chamar, se por todo lado as coisas se ordenassem do mesmo modo, obedecendo a um único movimento ${ }^{26}$.

Apesar de não ter sido diretamente mencionado, a referência a Heráclito e à ideia da harmonia de forças contrárias é evidente. O belo é o resultado de uma relação harmônica que surge a partir do contraste entre movimentos opostos.

Na prancha oito, de forma quase profética, aquele que é hoje um dos rios mais poluídos do Brasil, o rio Tietê, é equiparado ao Cócito: "tão logo nos afastamos das terras banhadas por este belo rio, entramos nos domínios do rio Tietê que dirige suas águas turvas como as do Cócito para os grandes rios Paraná e Paraguai" ${ }^{27}$.

Ao final da mesma prancha, Martius faz uma referência ao massacre dos índios nas terras brasileiras, com uma citação de Píndaro.

\footnotetext{
25 Martius 1996: 38.

26 Martius 1996: 40

27 Martius 1996: 42.
} 
Isto é o que podemos dizer das características desta regiáo. Ainda que eu deva mostrar como ficamos comovidos com esta floresta, percorrendo-a, contudo não posso negar que ela nos tenha parecido rude, triste e inóspita, do mesmo modo que nos pareceu ameaçador e feroz o aspecto dos primeiros habitantes que ainda viviam aí. Estes, originários do povo "caryôs" ou "guarûs", hoje se encontram privados de sua naçáo, dizimados pela varíola e pelas armas dos colonos cristáos. Alguns dos seus sobreviventes, dispersos e deformados, vivem entre os civilizados. Eles se acabam à maneira dos habitantes das sombras profundas. Como disse de cada um desses, de maneira excelente, o grande poeta dos tebanos: "Mas quem? Ninguém? O homem é um sonho de sombra". Isto vale também para os grandes povos: nenhum deles deixa vestígio e os ossos apodrecidos daqueles índios são cobertos pelas sombras indevassáveis da floresta que confirmam claramente o quanto a força vital das plantas supera a fragilidade dos homens ${ }^{28}$.

A prancha IX trata do espantar-se que dá origem à filosofia e que é a própria filosofia. Aqui é nítida a presença de um sentimento de sublime diante da natureza, que nos faz pensar na terceira crítica kantiana e na sua importância para a geração do movimento romântico.

Nessa prancha, uma máxima romântica é inicialmente destacada. É a ideia de que o mundo externo nada mais é do que um repositório das impressốes e dos sentimentos de cada indivíduo:

O espírito dos mortais, que sai de sua própria consciência como do mais profundo de si mesmo, difunde-se por toda a natureza. Os fenômenos e os corpos com que ele então entra em contato adquirem uma voz própria que lhes permite exteriorizar-se, e um coração próprio que pulsa com a força das paixóes, seja do amor ou do ódio. Esta voz das coisas, como uma imagem projetada delas mesmas, atinge o espírito humano, conforma-o, eleva-o. Na verdade, é o próprio homem que tira de si mesmo para atribuir às coisas exteriores tudo o que sente e pensa. Mas tudo isso retorna ao seu coração e o preenche e enriquece, como se ele estivesse recebendo, por meio da fala ou dos escritos, as opinióes e os pensamentos de outra pessoa ${ }^{29}$.

\footnotetext{
28 Martius 1996: 43-44.

29 Martius 1996: 45.
} 
Martius, então, descreve um sentimento de sublime diante das imensas árvores que contempla às margens do rio Amazonas, sensação semelhante nele despertada quando se deparou também com o imenso rio há pouco mencionado. Ele então afirma:

Ainda hoje aquelas árvores gigantescas me falam ao espírito e me enchem de um piedoso temor, ou me fazem vibrar no peito a mesma admiração inefável que tomava todo o meu ser. Esta admiração é a mesma que tomou conta de mim quando vi aquele rio largo e profundo, cujas ondas nem as razóes da inteligência nem os sentimentos do coração podem encontrar palavras com que descrever, pois as próprias palavras que nos sobrevêm e a emoção que sentimos dirigem o nosso espírito para aquele reino eterno e infinito em que só penetramos com uma pura e compungida veneração. É aquele "admirar-se" que Platão diz ser o início da filosofia, mas que eu considero ser o seu coroamento. Aquela audaciosa tentiva da inteligência de alcançar o absoluto, de descobrir o sentido do mundo, de conhecer com que finalidade ele é governado por Deus, de saber de onde surgiu a matéria ou de conhecer o bem e o mal que atingem o gênero humano - por ventura acreditarás que tudo isto é mais importante do que manter-se naquele temor respeitoso e naquela santa expectativa do espírito que se maravilha diante de todas essas $\operatorname{coisas}^{30}$ ?

A referência aqui é a passagem 155 d do Teeteto: "é próprio do filósofo a paixão pelo admirar-se; não há outro princípio da filosofia a não ser este"

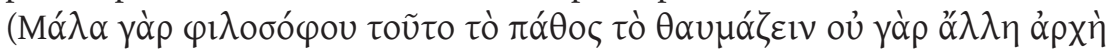
$\varphi \imath \lambda о \sigma o \varphi i ́ \alpha \varsigma$ ทे $\alpha u ̈ \tau \eta)$. É fundamental que seja notada, na passagem acima, uma certa crítica ao conhecimento sem piedade, sem a reverência diante do imenso desconhecido e do maravilhar-se diante do mundo, atitude que Martius diz ser condizente com a sua própria natureza e à qual ele foi levado pela sua admiração por Platão:

Estas considerações é que nos mantêm presos não a uma meditação estreita, mas a uma concepçáo piedosa com que preparamos o espírito para a compreensão de todas as coisas que Deus colocou diante de nós, de acordo com seus desígnios, a fim de que, com a sua exortaçáo, a mente e o coração do homem sejam tocados com o sopro inflamado da

30 Martius 1996: 45-46. 
aura divina, desta aura que por toda a parte reina, cria, alimenta e que, onde quer que esteja, se oferece para ser ouvida com o clamor da sua voz. Eu confesso francamente que sou um partidário dessa filosofia e até ouso aqui defendê-la. Depois de conhecer a verdade e penetrar mais profundamente no sentido das coisas divinas, estudei por mais tempo estas coisas e, com aquela dedicação que é própria do jovem honrado, me entreguei a essas rochas secas e a esses bancos de areia de meditaçóes táo fatigantes. Mas da natureza por um impulso interior, que não se origina apenas do entendimento, mas principalmente do espírito, que este ímpeto alimenta e estimula, fui levado da consciência de Deus, o que é inato em mim, para a admiração por Platão. E desta fonte límpida meu coração sedento bebeu a doce consolaçấo e encontrou o desejado repouso do espírito ${ }^{31}$.

Martius parece, portanto, pretender repetir no seu leitor a mesma experiência de admiração que ele teve, a partir das descriçóes por ele apresentadas e das belas imagens ali expostas. Com isso, a sua narrativa parece assumir uma perspectiva pedagógica, constituindo uma espécie de Bildungsreise, viagem de formação, tão típica do Renascimento, quando a Itália era considerada lugar ideal para adquirir conhecimentos científicos e artísticos. Assim, ele permite que aqueles que não têm os recursos que ele possui para participar de tal empreitada, também realizem, por meio de seu relato, a sua viagem de formaçáo. Ele se constitui em uma espécie de condutor de almas e, a natureza brasileira, o cenário ideal para essa viagem. Se no mundo externo encontram-se as projeçoos do mundo interno dos indivíduos, nessa perspectiva romântica, o relato sobre a viagem pelas terras brasileiras pode, assim, se converter em uma viagem pessoal para um conhecimento de si. Os lugares por ele descritos, paraísos e infernos no meio da natureza brasileira, podem, então, talvez ser pensados como lugares da alma humana.

\section{Consideraçóes finais}

As obras escritas pelos viajantes são marcadas pelos contextos histórico-culturais das épocas em que foram escritas. Revelam muito da forma como a identidade europeia é construída, assinalando especialmente o modo como cada cultura observa a outra, como analogias são traçadas em torno

\footnotetext{
31 Martius 1996: 46.
} 
de semelhanças e diferenças imaginadas pelos viajantes, a partir da projeção de elementos de sua cultura. Martius, imerso na filosofia da natureza romântica, influenciado especialmente pelo pensamento de Schelling e de Goethe, e pela proposta estética de Humboldt, viaja por dois mundos em que projetará seu olhar europeu: o mundo antigo e o novo mundo. É a partir dessa triangulação de olhares, da projeção do imaginário romântico europeu, sobre as novas terras e sobre a antiguidade clássica, que, em última instância, um olhar não só para esses dois mundos, mas, sobretudo, para o homem europeu e para si mesmo, é elaborado, permitindo que, nesse jogo de reflexos, a sua própria identidade possa ser repensada. Isso é sintetizado por ele mesmo ao final de sua prancha IX, após citar a Antígona de Sófocles:

De todo animal que a terra sustenta e nutre, nenhum existe que possa atingir a força de antiguidade daquele gigante a não ser o homem. Pois só ele pode derrubar aquele vigorosíssimo e antiquíssimo tronco com o ferro de seu machado. Só ele tem o poder de mudar todas as coisas que o circundam. É o que nos lembra Sófocles verdadeira e tristemente (Antigona 332):

"Muitas coisas são terríveis, mas não tão terríveis quanto o homem." Mas ainda que se considerando um vitorioso sobre todas as coisas, o homem há de se voltar sobre si mesmo e se perguntar quem ele é, quem é este Prometeu a quem nada restou senão a admiração por si mesmo, como se ele estivesse realmente convencido de pertencer a uma descendência de deuses. ${ }^{32}$

32 Martius 1996: 49. 


\section{Alexandre Schmitt}

\section{Bibliografia}

Foster, R. (2008), The Creativity of Nature: The Genesis of Schelling's Naturphilosophie, 17551799. Doctoral Thesis. Department of Philosophy. Houston: Rice University.

Humboldt, A. (1808), Ansichten der Natur mit wissenschaftlichen Erläuterungen. Tübingen: Cotta.

Humboldt, A. (2005), Cosmos: Ensayo de una descripción fisica del mundo. I. Madrid (18511852), Córdoba: Universidad de Córdoba.

Lisboa, K. M. (1997), A nova Atlântica de Spix e Martius: natureza e civilização na Viagem pelo Brasil (1817-1820), São Paulo: Editora Hucitec.

Martius, C. F. P. (1996), A Viagem de von Martius. Flora Brasiliensis. I. Tradução de Matheus, C. B., Barreto, L. L. P, Rosário, M. B. Rio de Janeiro: Objectiva.

Mazzari, M. V. (2010), "Natureza ou Deus: afinidades panteístas entre Goethe e o "brasileiro" Martius", Estudos Avançados 24 (69): 183-202.

Springer, K. (2009), "Consideraçóes acerca da Geografia de Alexander von Humboldt: teoria: filosofia e concepção de natureza”, Rảe $G a$. 18: 7-22.

Vitte, A. C. (2006), "Da metafísica da Natureza à gênese da Geografia Moderna”, GEOgrafia, 15: 23-50. 


\title{
Fantasia para dois coronéis e uma piscina Ecos clássicos num contexto do séc. $X X$
}

\section{português}

(Fantasia para dois coronéis e uma piscina.

Classical echoes in a Portuguese 20th century context)

\author{
Maria de Fátima Silva \\ Universidade de Coimbra \\ (fanp13@gmail.com)
}


Página deixada propositadamente em branco 
Resumo - Neste romance ${ }^{1}$, Mário de Carvalho foca-se, no essencial, no retrato do século XX português, no momento em que uma crise profunda o faz deixar para trás o passado das descobertas marítimas e do colonialismo, para rasgar um futuro incerto de adesão ao continente europeu. É sobre esta teia que, qual nota dissonante, o autor introduz elementos que são, na sua narrativa, permanentes: uma reflexão sobre aspectos teóricos da escrita e o regresso às fontes clássicas do pensamento europeu.

Palavras chave - fim do colonialismo, projecto europeu, mito, teoria literária.

Abstract - In his novel, Mário de Carvalho presents essentially Portugal in the twentieth century, at the moment when a deep crisis makes the country leave behind its colonialist experience and look ahead at an insecure future inside Europe. On this context, the author sounds a dissonant note, introducing other quite conventional condiments in his narrative: a reflection on literary theory and different classical elements present in European thought.

KEYWORDS - colonialism and its end, European project, myth, literary theory.

Num mesmo título, Mário de Carvalho combina 'o real em ficção' com o mais 'puro imaginário'. 'Fantasia' é talvez a grande palavra, a que nos antecipa fracturas num plano que se pretende 'objectivo'; e vários são, na intriga, os agentes e as estratégias responsáveis por essa metamorfose: um mocho e um melro, que, como em contexto de fábula, dialogam, numa crítica aos humanos, no galho de uma árvore; ou sobretudo o Emanuel Elói, o 'vedor de águas', de profissão tão rasteira e de nome tão claramente bíblico, tão 'bom moço' como um verdadeiro 'Cristo na terra', tão 'trotamundos' como qualquer Ulisses ou como qualquer português navegador e aventureiro.

E que país é este que se alimenta ainda de trotamundos idealistas, à procura de água nas profundezas alentejanas, e não já na borda de um território que se abre, naturalmente, ao Atlântico? Esse é um Portugal que, terminadas as campanhas em África, abandonou o seu passado de navegante de rotas infinitas, para se satisfazer com uma piscina, de recortes limitados, implantada em horizontes que agora miram a Europa. Ele também um trotamundos, um pouco à deriva, em busca de um futuro.

Aí entram na história os 'dois coronéis', velhos combatentes de campanhas ultramarinas de última geração. Expulsos, pelo tédio ou por qualquer 'guerrilha' com os vizinhos do prédio, da velha capital das descobertas, uma Lisboa agora inóspita, partem a viver as suas reformas para terras alente-

1 Lisboa, Caminho, ${ }^{3} 2004$. 
janas, a franja mais essencial do território, mais longínqua do mar, onde ainda abundam menires e cromeleques. Aí, num regresso às origens, vão, à falta de oceano, implantar uma piscina. Talvez uma 'nódoa' na paisagem. Mas, no romance, um verdadeiro pólo de mobilização, porque é em volta da construçáo dessa piscina que se pode juntar, uma vez mais, todo um país, que pensa e quer agir.

Eis, em breve síntese, a teia que subjaz ao romance de Mário de Carvalho, focada, no essencial, no retrato de um século XX português, no justo momento em que uma crise profunda o faz deixar para trás o passado das descobertas marítimas e do colonialismo, para rasgar um futuro incerto de adesão ao continente europeu. Mas é justamente sobre esta teia que, qual nota dissonante - a lembrar a 'nódoa' estabelecida por uma piscina na paisagem seca do Alentejo -, o autor introduz elementos que são, na sua narrativa, permanentes: uma reflexão sobre aspectos teóricos da escrita e o regresso às fontes clássicas do pensamento europeu.

\section{$\mathrm{O}$ incrível potencial da linguagem}

É antes de mais sobre a linguagem, como elemento do romance e factor de caracterização de uma sociedade, que Mário de Carvalho nos propóe uma reflexáo, com a mesma acuidade com que a velha retórica greco-latina assinalou, sobre o conhecido poder do discurso, um cânone de regras que transformaram em técnica sofisticada uma prática de séculos. Do discurso, a abertura do romance assinala, antes de mais, a polifonia. Entre 'falar' e 'dizer' restabelece-se uma antiga divergência; ao 'falar' reconhece-se o potencial de uma retórica fácil, múltipla no tom, avassaladora na abundância, vazia no significado, amoral nas interferências sociais que potencia; são seus atributos o ímpeto, 'a pulsão coloquial', um 'estado frenético de tagarelice', uma 'multiplicação ansiosa' de tons; no conjunto de estratégias e emoçóes, esta retórica meramente verbal nada mais consegue do que 'aturdimento', que estimula e valoriza o lado mais acrítico de uma sociedade. Esta é a experiência que a velha Atenas viveu pela mão da sofística, criadora de uma retórica persuasiva que justificou a decadência social e o horror dos verdadeiros 'filósofos' ou mentores de um colectivo que se pretendia ideal ${ }^{2}$. Em confronto, está o

2 É platónica a discussão que relaciona filosofia com retórica. Depois de condenar a retórica sofística em vigor na Atenas do séc v. a. C., como simples arte de persuasão, Platão defende uma retórica ao serviço da filosofia, que lhe permita o exercício da sua missão 
'dizer', a expressão oral de uma dialéctica de pensamento, que corresponde à verdadeira função da linguagem, 'ensinar' e 'comunicar' (11):

Assola o país uma pulsão coloquial que põe toda a gente em estado frenético de tagarelice, numa multiplicaçáo ansiosa de duos, trios, ensembles, coros. Desde os píncaros de Castro Laboreiro ao ilhéu de Monchique fervem rumorejos, conversas, vozeios, brados que abalam e escamoteiam a paciência de alguns, os vagares de muitos e o bom senso de todos. O falatório é causa de inúmeros despautérios, frouxas produtividades e más-criações.

Fala-se, fala-se, fala-se, em todos os sotaques, em todos os tons e decibéis, em todos os azimutes. O país fala, fala, desunha-se a falar, e pouco do que diz tem o menor interesse. $O$ país náo tem nada a dizer, a ensinar, a comunicar. O país quer é aturdir-se. E a tagarelice é o meio de aturdimento mais à mão.

Ao que náo pode deixar de sugerir antigas reflexóes sobre o poder da linguagem, que acompanhou, na Antiguidade helénica, o instalar de uma vivência democrática no colectivo social, justapóem-se outras tonalidades e funçôes. O solilóquio valorizou, nas palavras, o potencial emotivo sobre o persuasivo. Mais do que comunicar, ou interagir, 'falar com os seus botóes' permitiu confissóes de alma, confidências de opiniôes ou de projectos de vida, baseadas na expansão do individualismo (12):

Vai agora, pelos campos, para os lados de Vila de Frades, um apicultor, numa cansada bicicleta pasteleira. (...) Pois ainda que vagando sozinho, também faz conversa. Fala com os seus botôes. Nem os solitários escapam ao afã elocutório, porque a abotoadura, desde que foi inventada, tem o condáo mágico e tradicional de nutrir o paleio.

$\mathrm{Na}$ extensão a uma modernidade mais crua, o telemóvel, como multiplicador de vozes, deu à retórica do colectivo uma dimensão insuspeitada.

política e pedagógica. A esta 'verdadeira retórica' está associada a dialéctica, como uma forma de pensar, de argumentar e de comunicar conhecimento. Vide Yunis 2007: 75-89. Em Mário de Carvalho, esta introduçâo parece aplicar-se a uma sociedade que acaba de descobrir a liberdade de expressão, após a queda de um regime ditatorial, e que a usa com a mesma vertigem e precipitação que a democracia grega na Antiguidade Clássica. 
O que, no passado, se traduzia em diálogos de fronteiras mais estreitas, redimensionou-se à medida nacional (13):

Telefones móveis! Soturna apoquentação! Um país tagarela tem, de um momento para o outro, dez milhóes de íncolas a querer saber onde é que os outros param, e a transmitir pensamentos à distância.

Mas mais do que a medida relativa dos interlocutores ou destinatários do discurso, a retórica de todos os tempos valorizou a capacidade persuasiva, o seu poder de intervenção, de condicionamento de opiniōes, de argumentação, de que pode resultar a 'vitória', o prestígio, a defesa de interesses, e, se do colectivo se tratar, a determinação do voto ou da decisão. No seu germe estão os agones, as batalhas retóricas, em que o mundo ateniense, antes dos mais, encontrou motivos de prazer e fonte de sucesso político e de poder social. É um agôn no seu mais puro recorte técnico que Mário de Carvalho desenha em linhas que não se afastam de cânones consagrados $(26)^{3}$ :

Seja como for, quando dois faladores se deparam, frente a frente, num grupo, numa assembleia, numa festividade ${ }^{4}$, é mais que certo tentarem interromper-se um ao outro. O que arrebata a palavra, aproveitando qualquer distracção ou má gestão dos tempos, exulta e parte à desfilada. O outro fita o olhar, rancoroso, procura apoios, à esquerda e à direita, tenta infiltrar-se pelos interstícios, a ansiedade exprime-se-lhe nos lábios, muito abertos, na visagem, turvada de ódio, nas mãos crispadas, prontas a esganar. Não consegue penetrar? Minimiza o adversário, finge que não ouve, torna-se subversivo, distrai um terceiro, vai lá fora e fica a espreitar, tenebrosamente, por entre portas. Mas quando chega a oportunidade e o adversário se calou, por uma fracção de segundo, para apanhar a bengala de um idoso que entretanto ador-

3 Esta é, na sua expressão mais simples, a técnica dos pares de discursos sobre um assunto particular, um proferido em resposta ao outro, esgrimindo com a simetria dos argumentos.

4 Vide Gagarin 2007: 27-36, traça, desde Homero e Hesíodo, as raízes de um processo, latente nesta observação de Mário de Carvalho: já nesses textos arcaicos se torna patente que, em contexto político ou judicial, ou ainda nos elogios públicos em reunióes colectivas, a oratória tinha um lugar consagrado. As exigências da organização democrática da sociedade ateniense vieram trazer à velha prática um incremento particular. 
meceu, ei-lo que regressa, levanta ambas as mãos e retoma a arenga, com o outro pasmado, ainda de bengala na mâo, olhos fumegantes a prometer sevícias e a murmurar para o tal velhote: "O que aqui vai de verborreia! O gajo não se cala, hem?”.

O conflito verbal na sua essência imagina-o como de regra em lugar público, "numa assembleia, numa festividade". Do grupo, ou seja, do colectivo, provêm os oradores, em missão naturalmente contrastiva e numa posição de 'frente a frente'. Deste esquema 'abstracto', omite-se o que pareceria fundamental: o assunto. $\mathrm{O}$ sobre quê do agôn pouco importa; relevante é, isso sim, a táctica, o que os teóricos do passado chamariam os mechanemata, os recursos ou habilidades performativos que, mais do que os próprios argumentos, podem seduzir o auditório5. O vigor do discurso passa também pela gestáo dos tempos, pela capacidade de sabotar ou silenciar o adversário, pela impressão causada sobre um público mais ou menos abúlico e atordoado. A presença de um colectivo assegura um auditório, razão final da batalha retórica; captar-lhe a simpatia, contagiá-lo de emoções, ganhar-lhe o aplauso, desviar-lhe as atençóes do adversário, eis o que cada orador, mesmo silencioso, não descura; movimentos, expressões, sinais de conivência podem minimizar o opositor para que avulte a posição que se defende. Até ao desejado momento da réplica, que tudo anuncia simétrica, em pujança, dimensão e argumentos, com a intervenção a que sucedeu. Ao fogo, inesgotável, da retórica que, hoje como antes, poderíamos imaginar nos recintos públicos consagrados - o parlamento e o tribunal -, responde, como sempre também, o cansaço ou a indiferença do auditório. Ele espreita, ainda que discretamente, no episódio modelo deste agôn: identifica-se com a paciência abúlica ou com a surdez tolerante da velhice, que responde aos argumentos com um ensonado soltar de bengala.

Ao que parece o desenho de um paradigma, pode acrescentar-se uma ribalta concreta, daquelas que fazem parte do quotidiano de um qualquer simples cidadão, também ele, sem o saber, protagonista constante de múltiplos agones retóricos. Veja-se, assim, a agilidade do argumento numa simples comunicação entre condóminos, protagonizada pelo coronel Bernardes,

5 De certa forma, está aqui espelhada, nesta anulação do assunto, uma prática sofística: era conhecido o virtuosismo de que os sofistas e, mais tarde, os retóricos da época helenística procuravam dar provas, ao apresentarem discursos altamente elaborados sobre temas paradoxais ou vazios, como o elogio da mosca, por exemplo. 
militar na reforma e, por voto dos vizinhos, administrador para as questóes do prédio (28):

Apresentar um papel primeiro, guardar um outro para ser exibido só após a intervenção de ..., esperar que F... se espalhasse ao comprido para lhe apresentar a factura de ... Delícia das delícias, a do manobrador ...

Desta vez, o vigor do discurso ao vivo é substituído pelo formalismo do argumento escrito. E embora esteja implícito o motivo da mensagem - qualquer cobrança de despesas colectivas, com a apresentação sempre delicada de uma factura -, mais uma vez o que se valoriza é a 'manobra', o mesmo mechanema, que vive também da gestão dos tempos, da estratégia do contexto, do kairós ou oportunidade, numa interacção, com muito de jogo e artifício, com quem de vizinho passou a adversário.

Há, por isso, que reconhecer, se confrontados os diversos contextos, que o factor decisivo de sucesso não está no essencial, na questáo e nos argumentos que a servem ou documentam; importante é o 'espectáculo', a mobilização superficial dos auditórios por estratégias dirigidas não à razão, mas sobretudo às emoçóes; 'persuasão', a que os gregos baptizaram de Peithô e a que deram foros de uma deusa, continua a deter as rédeas do processo $(82)^{6}$ :

O busílis às vezes não está no que se diz, mas na convicção com que se diz. Aí é que se firmam e vingam as persuasôes que elevam ou lesam os espíritos.

\section{A língua ao serviço da criação da personagem}

Em Râs, a comédia que dedicou a avaliar os méritos relativos de dois dos maiores trágicos da trajectória do género - Ésquilo e Eurípides -, Aristófanes póe na boca do primeiro dos grandes nomes da tragédia esta consideração (1058-1061):

6 Continua válida, na sociedade contemporânea, a ideia de que o fracasso ou sucesso de um cidadão na vida pública depende em boa parte das suas capacidades de verbalização. Este princípio teve, em plena época clássica de Atenas, defensores intransigentes, de que Górgias é sem dúvida um nome destacado. A esses intelectuais ficou para sempre ligado o princípio de que a 'persuasão' é a principal virtude da arte de falar, uma arma indispensável na vivência colectiva. Vide, e. g., Bons 2007: 37-46. 
Só que, meu caro amigo, para sentenças e ideias de peso é preciso produzir uma linguagem à medida. E mais, é natural que semideuses usem um estilo mais empolado. Afinal também as roupas que vestem são mais pomposas do que as nossas. Eu mostrei o bom modelo, e tu acabaste com ele.

Como a voz de um padrão antigo de arte, equilibrado e isento de exageros, Ésquilo defende, perante o adversário, a mimesis que suporta a criação poética em termos de uma cooperação bem doseada. Não é indiferente a ordem pela qual o velho poeta enumera as suas ferramentas; na concepçáo que defende, a arquitectura do drama parte do assunto e logo das palavras que lhe dão expressão. A escolha de uma linguagem 'à medida' é, dentro desta visão, merecedora de apreço. Mas há que reconhecer que a inversão deformada deste equilíbrio, a aposta no desajuste gritante da linguagem face à personagem a que corresponde, é também susceptível de eficácia. É neste efeito de 'desequilíbrio' que reside, em Mário de Carvalho, um dos alicerces da personagem central da Maria das Dores, mulher do coronel Bernardes.

O nome estabelece - dentro de uma prática ancestral - um traço forte de caracterização desta personagem, não porque se lhe ajuste, mas exactamente pela dissonância. É forte a ironia que confere nome táo sofrido a quem se afirma pela independência, pela liberdade, pelo carácter forte, que se alguma relação tem com 'dor' essa reside no tormento de que contagia quem dela se aproxima, desde logo o marido. Anos de convívio conjugal testaram os dois alicerces da sua personalidade: uma linguagem libertina $\mathrm{e}$ uma não menos libertina propensão para o adultério. A propósito de um dos poucos rasgos de ternura de que a vemos capaz, face a uma situaçáo de crise doméstica - a dor causada no coronel e marido pela substituição a que foi sujeito na direcçáo do condomínio, a última réstia de autoridade que ainda lhe sobrava em tempos de reforma - é-nos dado da personagem um retrato expressivo (29):

Desta vez a esposa teve um momento de ternura (...) e murmurou: 'Ora, você devia era ginjar-se pra esta pardalada. Amandava essa merda desses papéis todos pró ecoponto e os gajos que se desamanhassem'. Era formada em História de Arte, educada pelo selecto Colégio de Odivelas, lia livros, sabia descascar e comer pêssegos, não usava talher nos espargos e, no entanto, exprimia-se destarte. (...) O facto é que, sem saber como nem porquê, fora essa particularidade vernácula que 
fizera o coronel interessar-se por ela, no baile de debutantes do Casino do Estoril.

Fascínio a que nem o coronel, e certamente também o leitor do romance, são indiferentes. A deformação da linguagem, em choque frontal com os traços do mesmo retrato, constitui, da personagem, uma das facetas mais conseguidas.

A Maria das Dores vem associar-se, por outro lado, o poder do epíteto, um elemento que a épica tradicional usou com insistência. O qualificativo que se cola à personagem ou grupo como traço de identificação tem referências paradigmáticas no 'Aquiles de pés velozes' ou nos 'Aqueus de belas cnémides' do contexto homérico. Sonoros, esses epítetos tornam-se como uma segunda pele, que pode mesmo substituir o nome. É nesse sentido que 'a baronesa' passou, com um alcance meramente doméstico, na boca do marido, a substituir-se a 'Maria das Dores'. Não como um louvor ou um reconhecimento de mérito por parte de companheiros ou amigos, do mesmo modo que para os heróis de antanho; foi por se sentir vítima de um deslize matrimonial, que não teve a coragem de punir com violência de marido ofendido, que o coronel Bernardes se armou do bastáo do epíteto (30):

Já o matrimónio ia adiantado, o coronel começou a tratar Dores por "a baronesa" ("ali a baronesa opina que ..., não sei o que a baronesa dirá, vou consultar a baronesa, a baronesa não está”) (...) Aquele apodo de "baronesa" estava carregado de veneno esverdeado, fétido, capaz de fulminar à distância, carente de subtileza e arte. Tudo força bruta e ânsia de desforço.

'Baronesa' valeu por 'alfinetada', com razóes claras de que a própria visada dá conta (184):

Acho que foi a partir dessa altura que ele começou a tratar-me por 'baronesa'. Para mostrar cagança, distância, está a perceber?

Igual expediente - o de encontrar para a personagem o 'nome falante' que melhor se lhe ajustasse, por razóes de conformidade ou de conflito - vigora no caso do Emanuel Elói ${ }^{7}$, que da importância do seu nome não deixa dúvidas, quando comenta (67):

7 Sobre o nome de Emanuel Elói, vide Bíblia Sagrada, Mateus 1. 22, 15. 34; Isaías 7. 14. 
O meu pai quis dar-me um nome benigno e abençoado e fez uma lista de que constavam os seguintes: "Eloim, Adonai, Sadai, Soter, Emanuel, Sabahot, Tetragrammaron, Alpha et Omega, Principium et Finis, Hagios, Ischiros, Otheos, Athanatos, Agla, Jehova, Homonsion, Ya, Iesus Christós, Messias, Elva, Elrei ..."

Predestinado para uma vocação claramente bíblica, ao detentor do nome de Emanuel cabe com propriedade, a descrição (14):

É uma bondade de moço, trotamundos, e tem algum jeito e muita paciência para os seus conterrâneos.

Ou ainda (81-82):

Ele é andarilho, gosta de bem fazer, meteu-se pelo país numa carrinha Renault Quatro, carunchosa, armado em explorador.

Pela intervenção que lhe é destinada no romance', o Emanuel veste de certa forma a pele do anti-herói. É difícil não ver nele uma réplica, desmitificada, do herói épico, ou mesmo do protagonista de uma utopia cómica (um qualquer Trigeu, Pistetero ou Evélpides, de Paz e Aves de Aristófanes), no que são os seus comportamentos: é frequentemente confrontado com uma atmosfera de maravilhoso e envolvido numa toada de alguma solenidade; são-lhe destinadas proezas sobre-humanas, irreais, e propostos trajectos que, além de fantásticos, são também anacrónicos; a presença de um deus protector, que lhe conduz os passos e lhe condiciona o destino, deixa-o próximo de qualquer Ulisses, ora protegido, logo atormentado, pelos olímpicos (45):

Mas o jovem Emanuel do Renault Quatro era um eleito muito especial do destino e favorito de uma caterva de deuses que seria fastidioso enumerar.

8 O empenho de um pai em encontrar para o filho um nome promissor, à medida do seu próprio projecto de vida, tem uma referência em Aristófanes, Nuvens 60-67.

9 Sobre a personagem do Emanuel Elói no romance, vide Simóes 2012: 67-69. 
Amigos ou inimigos são também os sucessivos interlocutores com que se vai confrontando; como se uma pincelada bíblica tivesse passado sobre paradigmas de um velho passado épico, são insistentes as expressóes que dão ao Emanuel Elói traços de bondade e filantropia ("é uma bondade de moço", "tem algum jeito e muita paciência", "gosta de bem fazer"). Mas lá está a menção do transporte, já não a nau a que um herói da Hélade sempre recorria para empreender trajectos de aventura, mas uma Renault Quatro, "carunchosa" de velhice, é certo, mas adaptada às exigências de um Portugal dos anos 60, a lembrar antigas odisseias. Esta é importaçáo de um género 'fechado', com regras próprias e tempo marcado, que, dentro do romance, estabelece um interessante efeito de incongruência ${ }^{10}$.

Diante de ouvintes pacientes, como para Ulisses foram os Feaces, o viajante tende à narrativa das suas aventuras, em momentos de lazer, que o são também de emoção e memória. Ouvidos mais ou menos distraídos encontrou-os o Emanuel numa Sandra, companheira de uma noite, na intimidade de um carro, em momento de descontracçáo. Foi então que, saltando do real para a fantasia, lhe contou uma daquelas atormentadas viagens, assaltadas dos terrores do mar, na sua Argos metamorfoseada em Renault Quatro, que em vez de o levar pelas ondas cerúleas do Mediterrâneo, o lançou, como bom português, pelo Atlântico, 'passando por Peniche', até à 'lonjura' da Berlenga (61-62):

Ele entâo contou daquela vez em que, passando por Peniche, tinha metido o velho Renault ao mar, pelo meio de uma vastidáo de ondas grandes, balanceadas, enjoativas. (...) Cruzaram-se com um navio porta-contentores enorme (...) Daí a umas horas chegava à grande Berlenga ...

Mesmo na solidão, sem ouvinte, as memórias de estranhas aventuras tendem a alimentar-lhe a imaginação. E muito ao estilo de uma 'história verdadeira', como a que saiu da imaginação fértil de Luciano de Samósata, ei-lo que se vê envolvido em estranho navegar, pelo Tempo e pela História, contrariando paisagens concretas ou fenómenos naturais, por um itinerário anacrónico no tempo e universal na dimensão (120-121):

10 Sobre esta divergência radical entre épica e romance, vide Reis, Macário Lopes 2007: 131 . 
Desta vez, não houvera oportunidade de contar (...) aquela ocasiáo em que, no Inverno, metera o carro às águas do Sado, perto de Alvalade, onde lhe chamam Ribeira, e fora seguindo, rio abaixo, e país acima, porque esse rio Sado, tal como o Nilo e os satélites de Marte, anda ao contrário, só para mostrar originalidade.

Ainda de dia, foi flutuando (...) saudado das margens por tractoristas e pescadores, vieram mais tarde os cais de Alcácer, as várzeas a estender de vista, os castelos, as feitorias fenícias, e o Renault sempre a vogar e a resfolegar de satisfação por estar a fazer uma viagem tão serena e aprazível.

Abria-se à direita um espaço pantanoso, de águas verdes e paradas. Aí os ares eram mais espessos, e o motor do Renault Quatro entrou a funcionar muito baixinho, num sussurro miúdo de quem não quer incomodar. Entravam no mar das estátuas. Até ao horizonte, em alinhamentos paralelos, equilibravam-se figuras, sobre pedestais, impondo a sua brancura de mármore a perder de vista. Das águas, limosas, compactas, soltava-se de vez em quando, com um ruído mole, uma exalação breve.

Às tantas, correu os ares aquietados uma música, leve e saltariqueira. (...) Quando a música se sumiu,(...) o velho carro deu meia volta, cruzou um banco de nuvens baixas, e após um longo percurso, começaram a ouvir-se as gaivotas. Afastavam-se de Tebas.

Já noite, entraram no estuário, encaracolavam-se agora as águas, dobraram Tróia, os golfinhos vieram saltar em roda, em funâmbulas saudaçôes, espadanando águas, e as gaivotas, em liso planar macio, acompanharam-nos lado a lado até à praia da Figueirinha, onde o Renault fendeu pela rebentação, rompeu pela dura areia molhada, patinou no declive flácido e foi dar à estrada da Arrábida, coberto de algas, conchas e caramujos, como se fosse o carro de um deus marinho.

Algumas referências a uma toponímia concreta mal chegam para camuflar a mais pura fantasia. Por nau usa-se ainda a Renault Quatro, uma espécie de segunda pele para o navegante português; e do Sado se salta para uma menção do Nilo, e de um dos mais imponentes rios do globo para os satélites de Marte, num derrubar ousado de barreiras, seguindo movimentos que ousam contrapor-se aos cursos regulares; "só para mostrar originalidade", no que é a confissão de um propósito também literário. Com a paisagem, também as criaturas e as cidades construídas fluem do concreto contemporâneo, o dos "tractoristas e pescadores", para o referencial histórico de sabor 
remoto, numa diacronia em retrocesso, dos 'castelos' de sabor medieval, até às feitorias fenícias, que tresandam antiguidade.

De aprazível, a viagem foi-se tornando cautelosa, às vezes lenta, quando se tratou de perfurar os arcanos do passado. Aos homens substituíram-se as estátuas, às saudaçóes das margens um silêncio cortado apenas por algum ruído leve de águas pantanosas. A imobilidade do tempo congelou e mumificou o calor e o ruído da vida. Uma música, tanto mais "saltariqueira", que ousou profanar o silêncio envolvente, trouxe o navegante e a sua "nau" de volta à realidade; foi aí que o trajecto se rompeu, para, dada meia volta, se regressar ao presente, visto já à distância um bastião do passado, Tebas ${ }^{11}$. Tróia, pelo que ressoa como símbolo da mais antiga investida europeia contra a Ásia, trouxe ironia ao relato, porque afinal, bem distante da sua homónima, mais não era do que um ponto da península de Setúbal, já bem próximo da praia da Figueirinha, onde golfinhos e gaivotas saudavam um outro Ulisses regressado a nova Ítaca. Terminava assim a gesta do Emanuel Elói, não sem que, para lhe denunciar a inspiração, lhe sobrassem, nas algas, conchas e caramujos que decoravam a carcaça do Renault, os traços inconfundíveis do carro de um qualquer deus marinho.

Porque os deuses, essas entidades que se confundem com um passado remoto, nunca abandonam as rotas percorridas pelo trotamundos lusitano. Em mar, como em remotas estradas alentejanas, lá estão eles a condicionarem-lhe o destino e a imporem-lhe uma identidade de verdadeiro herói. Foi assim que, quando o assaltavam perigos latentes, daqueles que ameaçam um condutor imprudente que abre a porta do seu carro ao desconhecido que pede boleia, uma epifania lhe ditou estranhos encontros (156):

Certamente, o país está ameaçador, claro que dar boleias a desconhecidos pode ser uma exposição irresponsável ao berbicacho, é evidente que se deve ser desapiedado e descurioso e passar adiante, sem olhar sequer para o lado. Mas duas razóes levaram o jovem Emanuel a trilhar os calços. A primeira é que, ao passar pelo castelo de Alvito, hoje apousadado, tinha distinguido, nos adarves de uma torre, uma figura, desta vez feminina, de capacete parecido com o dos bombeiros, uma coruja

11 Tebas constitui, em Mário de Carvalho, uma referência paradigmática a um passado, onde a Humanidade encontra o contexto mais remoto da sua experiência. Ver Tebas seria, para cada um de nós, ver-se a si próprio, perceber o mundo onde, como homem, desde sempre existiu; nesse sentido Tebas é 'a pátria', um primeiro marco de civilização. É esta aspiração em recuar na História à procura de um passado que transcende o dos registos de um arquivo, que transborda do relato que o mesmo autor intitulou O livro grande de Tebas, Navio e Mariana ${ }^{3}$ 1996. Sobre este assunto, vide Silva 2012: 13-30. 
ao ombro, muito resplandecente, a ponto de sobrepujar os holofotes da Câmara e que parecia ter sido ali depositada, no momento, por uma grua de construçáo civil. E como nada nestas jornadas acontece por acaso, foi por a deusa ter indicado aquela estrada, de entre os caminhos e direcçôes possíveis, que Emanuel a escolheu, e num nexo de causalidade ditado pela apariçáo foi encontrar o tal sujeito que pedia boleia.

Com a costumada anacronia, é o castelo de Alvito, com o seu toque medievo, que serve de cenário à imprevista apariçáo. Num recorte feminino, coroado de um capacete que, no mundo de hoje, lembraria o dos bombeiros, e de coruja ao ombro, cercada de luz, lhe aparece uma inconfundível Atena, com os seus habituais atributos. Vinda ex machina, no braço de uma grua, a deusa ali surgiu para pôr o seu protegido, como o Ulisses viajeiro, no caminho certo, que o levasse ao cumprimento de uma missáo ou de um destino.

\section{A composiçáo do romance e as suas regras}

Da reflexão focada nos efeitos de linguagem com que abre o romance, Mário de Carvalho passa directamente à consideração das regras que presidem à criaçáo literária ${ }^{12}$. Como seus porta-vozes, delega nos dois coronéis a ponderação técnica do assunto. A ironia é gritante, transformada numa espécie de exemplo do "linguajar nacional". Tomando o acaso como mãe incontestada de todas as descobertas ou enunciados, o autor distorce, ao sabor de uma tyche caprichosa, a emissão de pressupostos teóricos. O contexto é informe, desregulado, mas principalmente imprevisível: "duas altas patentes na reforma tagarelam um tanto à solta" (15); a competência dos interlocutores de duvidosa qualidade; lugar e momento fugidios, "à beira de uma determinada piscina, em lugar ainda incerto"; a expressão teórica superficial e involuntária; e, no entanto, ali está o desafio de um título a exigir dos coronéis Bernardes e Lencastre uma reflexáo literária. Abandonado numa poltrona pela dona da casa, a Maria das Dores, está um romance, leitura relaxante do momento, que cativa, do simples exterior, a atenção dos dois tagarelas; a um Lencastre, que há bons trinta anos não pôe os olhos num

12 Sobre este tipo de reflexão incluída no próprio romance, como prática comum neste autor, vide Oliveira Martins 2012: 31-53. 
romance, e a um Bernardes, para quem a leitura parece ócio de mulheres, o livro esquecido mobiliza para o comentário.

Muito ao gosto de Mário de Carvalho a atenção fixa-se no título; linear e falho de imaginação, denuncia uma gritante falta de talento, a mediocridade do óbvio, a inabilidade que começa com o mero enunciado da capa. E basta um simples relance pelo interior, não de quem lê mas de quem 'folheia', para que a previsão do coronel se concretize (15):

O Apicultor e o Bidão de Mel, raio de título. É dum desses autores portugueses que andam por aí, nabóides a escrever. Estive a folhear. Um atraso de vida. Perdas de tempo, deambulaçôes, opinióes, descriçôes, filosofias, desarrumação ... um bocejo, pá.

No comentário, aparentemente despretensioso, vai contida toda uma receita de composiçấo literária. É, antes de mais, a estrutura que está em causa. E o apreço vai para uma construção linear, recta, coesa, de onde estão excluídos todos os elementos perturbadores, excursos inúteis, intervençóes marcadamente extradiegéticas, anacolutos indesejáveis. Proscrito é afinal o modelo que a própria Fantasia pratica, reprovado por aqueles que são seus agentes activos, as personagens centrais dos dois coronéis. Em perspectiva claramente horaciana, o Bernardes prossegue agora com matéria delicada: o como dar início à narrativa. Inspirado em estratégia da velha épica, receitada por Horácio como ideal (Arte Poética 148), à clareza e linearidade junta-se o começo in medias res, o mergulhar num ponto avançado para abrir espaço à analepse ${ }^{13}$, ao flash back, táo bem sucedido que acabou predilecto de outras artes, nomeadamente o cinema, inconsciente da dívida com o passado milenar de uma Ilíada ou de uma Eneida (15):

Eu, cá por mim, um livro deve apressar-se para o evento, começar logo a meio da coisa e eliminar os desvios e as imaginaçóes que só servem para encher.

Definidos aspectos primordiais - a trama elementar, o ponto de partida -, desta vez o Lencastre, inspirado em Aristóteles ${ }^{14}$, passa a enunciar o que

13 Vide Reis, Macário Lopes ${ }^{7}$ 2007: 9, 29-31, que nos fornecem a seguinte definição: "por analepse entende-se todo o movimento temporal retrospectivo destinado a relatar eventos anteriores ao presente da acção e mesmo, nalguns casos, anteriores ao seu início".

14 Poética 1450a 8-10: "É necessário, portanto, que toda a tragédia tenha seis partes pelas quais é definida. São elas: enredo, caracteres, elocução, pensamento, espectáculo e música”; $1450^{a}$ 39 - 1450b 18: "O enredo é, pois, o princípio e como que a alma da tragédia; e, em segundo lugar, vêm, entâo, os caracteres (...) A tragédia é a imitação de uma acção e, através dela, principalmente 
para o Estagirita eram os elementos da tragédia, mas que afinal se aplicam a uma outra narrativa (16):

Eu acho - dirá - que o mais importante é o entrecho, a acção. Depois vêm as personagens e respectivo desenho moral. A seguir, o pensamento, os conceitos. Mas também a maneira como está escrito, o português, se é bom ou mau. Há ainda a toada, o ritmo, que é importante. Finalmente, o modo como os acontecimentos são postos diante dos nossos olhos, a ... como hei-de dizer? A espectacularidade da coisa.

E não se contenta em coincidir com o teórico grego no mesmo elenco de componentes, mantém-lhes também a hierarquia. Em confluência com o proprietário da piscina, o Lencastre é também adepto da linearidade que se obtém - e volta a citação do velho mestre do Liceu ${ }^{15}$ - de nexos sólidos de causalidade e articulação entre os diferentes episódios (16):

-Pois, para mim, os factos devem estar numa tal relaçáo que, suprimido ou deslocado um deles, também o conjunto se transforme ou confunda. O que se pode acrescentar ou tirar sem consequências não faz parte do todo. Esta é, pelo menos, a minha modesta opinião.

Desta anacrónica e paradoxal sobreposição - a que póe um coronel reformado, no Portugal do séc. XX, a citar de Aristóteles teorias literárias enunciadas no séc. IV a. C. na Grécia -, Mário de Carvalho, omisso quanto às autorias, limita-se a lançar ao seu leitor um vago alarme (16):

-E as piscadelas de olho? Há gajos que se fartam de fazer citaçóes encapotadas só para ver se a malta dá por isso!

dos homens que actuam. Em terceiro lugar está o pensamento (...) Em quarto (...) vem a elocução (...) Das restantes partes constituintes da tragédia, a música é o maior dos embelezamentos, e o espectáculo, que se é certo que atrai os espíritos, é contudo o mais desprovido de arte e o mais alheio à poética”. Tradução de Valente, A. M. (2004), Aristóteles. Poética, Lisboa, Fundação Gulbenkian.

15 Poética 1450b 21 sqq.: "Ser um todo é ter princípio, meio e fim. (...) É necessário que os enredos bem estruturados não comecem nem acabem ao acaso, mas sim apliquem os princípios anteriormente expostos”; 1450b 31 sqq.: “... também o enredo, como imitação que é de uma acção, deve ser a imitação de uma acção una, que seja um todo, e que as partes dos acontecimentos se estruturem de tal modo que, ao deslocar-se ou suprimir-se uma parte, o todo fique alterado ou desordenado. Realmente aquilo cuja presença ou ausência passa despercebida não é parte de um todo". 
Com os enunciados das suas personagens, que são também os do autor da Poética, não se compromete o autor / narrador de Fantasia. É com frontalidade que, mais adiante, sugere o encanto de um bom anacoluto, a quebra de uma coesão rígida, a fractura inesperada, que cria suspense e não é isenta de fascínio; sem cerimónias, é ele desta vez quem teoriza, num apelo frontal ao leitor, mesmo o mais experiente nas lides narrativas (60-61):

Tentação enorme, ó experiente leitor ${ }^{16}$, de parar aqui e mudar de foco. Fazer actuar o efeito de deferimento (...). E mudar de capítulo, passar para Sáo Jorge de Alardo, ou Lisboa, e o leitor ansioso, a procurar nas páginas mais adiante, a querer saber se Emanuel foi estraçalhado pelos câes, ou se lhe apareceu, pendurado do alto, aquela figura divina e providencial que costuma desviar-lhe os caminhos. Mas eu não sou escriba manipulador, especioso em ganchos, clif-hangings e outros artifícios para prender a atenção do narratário. E já sofri por isso. Vozes se levantarão contra os meus processos tão cristalinos de limpidez e boa intenção. Eu sou franco, não há arcas encouradas, digo logo tudo.

\section{A arte do anacronismo}

Disseminados pela narrativa, muitos são os processos formais e estéticos que continuam a ressoar modelos testados desde a mais remota Antiguidade. Alguns não passam de estratégias literárias, marcadamente convencionais, mas que se revitalizam pelo novo contexto em que se inserem e pelo claro choque que estabelecem com uma narrativa distante no género, e mais distante ainda no tempo. É o caso da invocação à Musa, que a tradição consagrou como marca de uma expressão matricial na literatura europeia, a épica. A Musa encarnou então, simbolicamente, a capacidade criativa, como inspiração / talento estético, e, mais ainda, como memória, garantia de um conhecimento e de um rigor que correspondeu a uma fase de expressão oral, a fluir entretanto para o registo escrito dos poemas. Após breves páginas com sabor a prólogo, onde, como vimos, o autor define pressupostos estéticos essenciais - sobre a linguagem e sobre a construção estruturada do romance -, é chegado, com o momento de facto inicial da intriga, a frase

16 Esta é uma técnica, comum em M. de Carvalho, correspondente ao que Reis, Macário Lopes ${ }^{7} 2007$ : 207-210 designam por "intrusão do narrador"; é seu objectivo essencial integrar no enunciado narrativo a subjectividade do narrador. 
de invocação, incluída, ela também, in medias res. Ao motivo, Mário de Carvalho associa o tom que lhe é convencional (17):

Parte, pois, vai pensamento sobre asas douradas, foge, deixa-te levar pela gentil Polímnia, grácil musa que por mim zela, e que não rejeito invocar, busca-me o lugar geográfico daquelas falas ...

Com uma figura poética que traz de imediato 'as palavras aladas' de Homero à lembrança do seu leitor, promove-se o apelo a Polímnia, a Musa 'de muitos hinos', patrocinadora de muitas tonalidades ou géneros, conciliadora entre a velha épica e o romance contemporâneo, na maior indiferença pelo lapso temporal e pela discrepância poética. O patrocínio que se espera é, neste momento, sobretudo estético; 'pensamento' e 'musa' fundem-se numa espécie de suspensão etérea, feita da leveza e inconsistência de um voo, desenhada com 'gentileza' e 'graça', privilegiando a beleza como factor primordial da criação. Mas sem esquecer a cooperaçáo da Musa como memória, aquela que funciona como 'arquivo' de informação, base de dados para elementos táo comezinhos como 'o lugar geográfico' onde situar o episódio.

Ultrapassada a abertura, a Musa continua presente na narrativa, como bordão permanente na coesão de diferentes componentes e na redução de fracturas; assim "quando o discurso e a escrita se interrompem, bem como qualquer actividade racional" (20), o retomar da narrativa pode exigir uma nova intervençáo da Musa; trata-se agora de simples funcionalidade, na hora em que se pretende romper com um passado e enquadrar os dois coronéis no ambiente, de certa forma 'desintegrado', onde vão viver o enredo que os espera; o primeiro passo é cortar, pela força repetitiva das negativas, com o seu mundo, deslocá-los de um quadro urbano para os inserir em ambiente bucólico (20):

... não guardam arames entre as ramagens (...), não deixam sacos de adubo ao vento, não abandonam velhas máquinas (...); não largam entulhos (...), não matam abetardas (...), não envenenam faunas (...), não cortam chaparros (...), não plantam eucaliptos (...), não ateiam queimadas (...), não atiram para o chão cascas de melancia, não se esquivam aos impostos, não intrujam nos negócios (...) separam os lixos, isolam as pilhas, ensacam o conjunto e, com regularidade, acabam por deixar tudo no contentor camarário mais próximo ...

É neste abandonar dos maus hábitos urbanos, indiferentes à protecção da natureza, para se acomodarem a práticas amigas do ambiente, numa co- 
operação intuitiva com novas regras de vida, que a Musa - "e demais luzidas divindades", sobretudo aquelas a quem a pureza rural mais deve - é tomada como testemunha do trajecto operado pelos coronéis (20):

Musa excelente e demais luzidas divindades, é justo arguir que eles não guardam arames entre as ramagens das árvores ...

Já agora, por uma razão de justiça natural, convém, bela musa, que anotes estes sons que, apurando bem o ouvido, provêm das casas dos coronéis e que espraiam suaves compassos de Albinoni e Monteverdi ...

Numa espécie de aditivo - "já agora ... convém” - o autor consente um regresso ao passado e salva alguma coisa daquele urbanismo lisboeta que, apesar de todas as adaptaçóes, soa ainda pelas janelas das casas dos coronéis, em plena planície alentejana. Esta é, claramente, a Musa da memória, a que nos não deixará esquecer a raiz citadina destes dois alentejanos de adopçáo.

É ainda com uma menção da Musa que o romance encerra (227):

Nô mais, ficção, nô mais! Desce tu, Musa, a de sorriso loução, ganha-me a benevolência dos meus concidadáos e diz-me: Há emenda para este país?

Num último apelo à Musa, no momento de rematar a narrativa, a alternância entre 'ficção' e 'Musa' deixa evidente o simbolismo da filha de Zeus e Harmonia. O sentido é o de uma captatio beneuolentiae; a toada a de uma paródia do mais paradigmático dos poetas portugueses, o épico Camóes (Lusíadas 10. 145), no justo momento em que, abandonada a saga que deu matéria para os Lusíadas, é altura de formalizar uma interrogação decisiva para uma sociedade em busca de um futuro: "haverá emenda para este país?"

Mas além da invocação à Musa, nas suas diversas cambiantes, o velho Homero tem ainda outras sugestóes a dar para colorir o anacronismo voluntário da narrativa portuguesa. As velhas fórmulas, aquelas que suportaram, num passado de oralidade, o recitativo dos aedos, podem ainda desempenhar, em contexto mais prosaico, funçáo equivalente. Dentro de um carro, ninho de amor para um par de ocasião, a lembrar um Ulisses enleado nas teias de uma qualquer imprevisível Circe - na versão portuguesa, um Emanuel nos braços de uma Sandra -, se assiste, em saboroso relaxamento, ao nascer do dia e lá vem, como eco de um aedo inspirado da Grécia arcaica, a referência à eterna Aurora (61):

Daí a umas horas, vinha perto a manhã, já toava a orla do céu a aurora de róseos dedos ... 
Das demoras infindáveis do bricolage, com que o coronel Lencastre animava os seus dias, sobrevêm os artifícios de Penélope (146):

Por essa altura já havia toda uma manhã de trabalho na miniatura do Galeâo Grande, que lembrava a teia de Penélope. Todos os dias o coronel Lencastre usava a manhã para desfazer meticulosamente a aplicação maljeitosa da véspera.

Tudo é ironia no enunciado da tarefa; retirado das lides ultramarinas, o coronel na reforma ressuscita, com máo inábil, a lembrança de um velho Galeão, talvez maqueta de uma nau das descobertas, Grande apesar de não passar de miniatura, qual brinquedo de criança. No eterno fazer e desfazer, Lencastre reproduz a famosa esposa de Ulisses. Mas se seguia, sem o saber, o paradigma, colhido em Ítaca, da resistência, hábil e fina, de uma teia, a persistência redunda em teimosia, de mão desajeitada que, à luz do dia, não tolera a "aplicação maljeitosa da véspera".

Este tipo de referência confessa a algum tópico, literário no caso, com a marca de um passado alterna com alusôes a outros motivos clássicos, de modo disperso e discreto, que deixam à acuidade do leitor o reconhecimento. Uma só palavra pode realizar o milagre e trazer à mais gritante contemporaneidade esse processo de metamorfose. É assim que o simples preparar de um uísque, de resto clandestino para escapar às censuras da mulher, o erguer do copo para avaliar a pureza da bebida, pode ganhar, por força das palavras, o tom de um verdadeiro gesto ritual; "olhou-o à transparência", "aspergiu umas gotículas", "ergueu-o ao alto" (23), se são palavras de total ambiguidade, desfecham numa inconfundível revelação (23-24):

Convém anotar, por ser bonito de ver, que neste fugaz instante em que o coronel levantou o copo poderia ter-lhe dado um raio de sol da manhã e dardejado luminosidades douradas e brancas, susceptíveis de serem lidas como louvor à planície (...) O coronel Bernardes não demorou muito aquele gesto alevantado que, surpreendido por olhos longínquos ou distraídos, podia ser entendido como uma libação.

O toque possível de um raio de sol, que arrancasse "luminosidades douradas e brancas", poderia tornar sensível a presença de um qualquer Apolo ou Dioniso, e transformar o prazer de um uísque, ainda para mais clandestino, num "hino de louvor" à natureza ${ }^{17}$. "Libaçáo" é, por fim, a palavra que impóe, sem reservas, o recolhimento ritualístico do gesto e a interpretação mística da cena.

17 Algo como a descrição que Eurípides faz, no seu Íon, do nascer do dia, que é também a chegada de Apolo, em Delfos, pode ser invocado. O romper do dia funciona como 
Falar de 'fortuna', sobretudo sublinhando a sua principal característica - a fugacidade - retorna sem dúvida a um dos conceitos básicos da cultura grega antiga. A ideia de uma tyche, 'fado ou acaso', que domina a vida humana e a ameaça com os seus constantes caprichos, tem, na tradição antiga, referências incontornáveis. Este é um dado com que a tragédia, sobretudo a euripidiana, conta como adquirido para explicar a imprevisibilidade das peripécias que atormentam o Homem, aquele passar, rápido e inexplicável, da ventura para a ruína. Que a fortuna seja fortuita, ingrata e cega na distribuição dos seus favores - todos eles traços de caracterização da velha tyche ${ }^{18}$-, está espelhado por Mário de Carvalho quando escreve (28):

Mas a fortuna é uma amiga de uma noite. Em nos encontrando na rua, no dia seguinte, se calhar, finge não nos reconhecer. Ainda um homem lhe sorri, já ela voltou as costas e vai acalentar outro que menos a soube merecer.

Este contexto 'doutrinário' serve de prólogo, em Fantasia, a um episódio a que, com travos irónicos, não faltam 'laivos de tragédia'. Trata-se, simplesmente, de retornar, a propósito da substituição do coronel Bernardes na função de administrador do condomínio, ao velho tema do conflito de geraçóes e da caducidade da vida (28):

Num serão nefasto, certa comissão espontânea, clandestinamente constituída no prédio, com vezo de delegação de notáveis, composta de jovens engenheiros e advogados, veio muito de mansinho com uma conversa, que, a pouco e pouco, insinuava ser preciso rejuvenescer a administração ...

Sem dúvida que a mão de tyche está ao comando dos acontecimentos; o tom dado por termos como "nefasto", "clandestinamente", "muito de man-

um toque mágico que dá vida ao que antes era apenas imagem. As primeiras palavras que Íon, como representante do lugar, pronuncia são uma espécie de hino ao sol, que anuncia a chegada de um novo dia (82-85). O brilho que domina (83-84), como marca de Apolo, inunda toda a terra. Como prova da ordem que caracteriza o santuário, a aurora manifesta uma harmonia exemplar: "os astros fogem então do éter que se abrasa com essa chama para a noite sagrada” (84-85). Com a sua autoridade olímpica, a luz de Apolo articula os dois momentos do tempo universal, o dia e a noite. Em Delfos, são os cumes do Parnasso quem primeiro recebe o toque da luz, também eles sacros porque inacessíveis e inviolados.

18 Talvez a avaliação do conceito feita por Sólon, um Sábio da Grécia, perante a ignorância bem humana de Creso, o senhor poderoso da Lídia (Heródoto I. 32-33), em tudo aquilo que ela tem de imprevisto e instável, possa ser uma das reflexóes referenciais para esta alusão no romance português. 
sinho" denunciam-lhe a quase falsidade, e aquele carácter imprevisível para quem com ela se defronta. Impiedosa, ela actua, sem perdão, sobre o fatal ciclo da vida, conhecido, mas nunca 'esperado'; tal como a vida, a comissão dos moradores é "espontânea", desencadeia-se automaticamente, para atirar em rosto do coronel na reforma a necessidade de "rejuvenescer" a autoridade no prédio, exigida por um grupo de "jovens" engenheiros e advogados, senhores da vitalidade dos poucos anos e de uma competência profissional que diverge do comando 'já rançoso' do passado. Tyche, pela imprevisibilidade do momento, harmoniza-se com Moira, como um destino pré-determinado, aquele que fatalmente o passar dos anos impóe.

A Moira não está também alheia à reflexão de Mário de Carvalho, quando mais adiante escreve, a propósito dos trabalhos que prosseguiam para a construção da piscina em terrenos do coronel Bernardes (126):

E assim sorriu a sorte a Desidério e Eleutério, que, sem terem de usar nenhum estratagema, nem de puxar pela cabeça ou por artifícios sempre falíveis, se viam desembaraçados do coronel, como se as suas intençôes tivessem sido compreendidas e aprovadas lá do Alto, onde se distribui a sorte pelos malandros.

Além da assonância graciosa, os nomes dos dois operários aprofundam um sentido, o de 'desejo' e o de 'liberdade', no conjunto constitutivos de uma feliz equipa: um desejando outro aludindo a uma liberdade que dois operários modelares sempre alimentam de ausência de vigilância ou do controle de quem lhes paga. Desta vez, os factos parecem escusar os 'estratagemas, artifícios' (mechanemata ou doloi teriam igual sentido), com que o ser humano, na sua 'trágica' experiência de vida, procura tornear os arremessos do destino. Uma força maior, como que obedecendo à previsão de uma qualquer divindade, se encarregou de uma das suas superiores missóes, "a de distribuir a sorte" ... pelos malandros. Subjaz a esta sucessão de avaliaçóes do destino a mesma doutrina que os Gregos traduziram e interpretaram com diferentes vocábulos: tyche, ligada com um tynchano, 'encontrar por acaso, deparar-se', carregada de imprevisibilidade; e moira, da família de meíromai, 'distribuir', reverente a um determinismo que uma força superior, coordenadora do destino do universo, se entreteve a organizar.

Sobre o peso condicionador que um e outro conceito tradicionalmente exerceu na narrativa literária, desde as suas formas mais antigas, fala a confissão do autor, que parece - num falso desejo de inovação - pretender excluir da sua criação aquelas que são as suas manifestaçóes, "acasos e causalidades manipuladas" (82): 
De resto, esta é uma narrativa contemporânea - acho eu - que desconfia dos acasos e das causalidades manipuladas...

A uma das personagens mais simbólicas do romance, o Emanuel Elói, é atribuída uma narrativa que retoma um motivo de sucesso na literatura grega, desde a épica, com particular incidência no teatro e, mais tarde, na novela - o sonho ${ }^{19}$. A convenção deste processo está bem definida e reconhecível em Fantasia (35):

Durante o percurso Emanuel contou uns sonhos que estava a ter. Não havia necessidade nenhuma de contar, nem Eleutério era um interlocutor apropriado, de quem se esperasse interpretaçóes particularmente sagazes, mas, para entreter a noite e distrair o outro, que se mostrava cada vez mais sombrio e enervado, sem deixar em paz o fecho da janela, explicitou:

-Eu estou assim numa espécie de eira, redonda, e há na minha frente uns painéis enormes com umas pinturas que são umas florestas, com uns rebanhos, e tal. Sei que está mais gente em volta, porque sinto, quase lhe cheiro o bafo, mas não vejo ninguém. De repente, por cima da minha cabeça zune uma espécie de guindaste de pau, pró tosco, e sai de lá um fulano muito alto, de grande espalhafato, com uma cara torcida, uma bocarra medonha e cabeleira arreganhada, que desata numa tremenda gritaria em língua de trapos. A voz entoa e enche o espaço todo. Ah, e um gesto larguíssimo, autoritário, como se estivesse a mandar em mim. Deve ser um deus. O amigo sabe o que é um deus? -Eu só conheço o Deus-pai-todo-poderoso, alto está, alto mora, ninguém o vê, todos o adoram.

-Ná, estes são deuses diferentes. No plural: deuses, está a ver?

Se o sonho da tradição helénica ocorre em contextos de alguma ansiedade ou tensão e tem por objectivo comunicar a quem o experimenta a previsão de algo que fatalmente vai ocorrer, é neste aspecto fundamental que Mário de Carvalho introduz uma primeira divergência; como que dialogando com uma prática assumida, vai, discretamente, produzindo a sua desmontagem; à tensão substitui-se a descontracção, o relato de um sonho como simples lazer, ou até mesmo como factor de relaxe para quem dá sinal de preocupação. Sem omitir o interlocutor, no esquema tradicional também o intérprete da visão, o autor

19 Sobre a potencialidade dramática dos sonhos, vide Devereux 1975; Lévy 1983: 141-168; Pereira 2008: 11-28, 2009: 5-18. 
português despe-o de funções e de competência, ao considerá-lo inapropriado porque falho de sagacidade. Afinal a maior frieza que se espera do ouvinte, perante a emoção de quem narra, está, nesta versão, também subvertida.

Invertidos os pressupostos, sucede-se a narrativa da visão; e nessa estáo igualmente expressos traços convencionais. A definição de um 'cenário' coloca o processo no contexto teatral, onde os painéis estabelecem um pano de fundo rústico. $\mathrm{O}$ próprio público, numeroso, de presença forte, sente-se em volta, ainda que não visível, estabelecendo uma fractura acentuada entre a 'ilusão cénica' e a realidade. A cena anima-se com a mobilização da mechane, a máquina de voo, um dos 'efeitos especiais' a que a tragédia grega deu espaço na fase final da sua expansão, terminava o séc. $\mathrm{V}$ a. C. A descrição parece corresponder àquilo que modernamente se tem por apropriado a esse recurso cénico: "uma espécie de guindaste de pau, pró tosco". Suspenso dele vem, naturalmente, o actor, e também sobre ele as informaçóes são concludentes; avantajada em altura, como é próprio das imagens vistas em sonhos, a figura tem todos os adereços de uma personagem teatral, máscara de traços carregados, a emitir uma voz "em língua de trapos", que nos atreveríamos a identificar com o grego. A voz soa forte, como se exige da elocução teatral, mas também porque afinal a figura que voa é um deus, o deus ex machina, um recurso de potencialidades que a novela de Mário de Carvalho não acha despiciendas.

Na velha tradição dramática, o deus ex machina funciona como uma soluçáo de último recurso; quando tudo parece perdido, quando os acontecimentos, confusos ou incompatíveis, inviabilizam um final coerente, um deus virá que, da sua elevada autoridade, terá artes de sanar o problema. É deste processo artificial, que denuncia, em termos literários, a incapacidade de conduzir a um desfecho uma acção coerente, que M. de Carvalho se diz inimigo (222):

Agora eu juro, juro por todos os deuses do Olimpo, Musa que me ouves, leitor que me crês, que fui surpreendido por esta detonaçáo, tanto como todos. Quem só tenha aberto o volume nas últimas páginas pensará, estando de má-fé, que eu introduzi aqui, à socapa - como se fosse capaz disso -, um dispositivo dito 'd. e. m.', o mesmo é dizer: deus ex machina.

Estes são alguns tópicos de marca inconfundível, que, na intertextualidade tão do gosto de Mário de Carvalho, impóem na sua narrativa, de modo mais ou menos disperso, a presença de uma teoria e convençáo literária que, na Europa, davam os primeiros, mas decisivos, passos. 


\section{Maria de Fátima Silva}

\section{Bibliografia}

Bons, J. A. E. (2007), "Gorgias the sophist and early rhetoric", in Worthington, I., A companion to Greek rhetoric. Oxford, Blackwell: 37-46.

Carvalho, M. ( $\left.{ }^{3} 1996\right)$, O livro grande de Tebas, Navio e Mariana. Lisboa: Caminho.

Devereux, G. (1975), Dreams in Greek tragedy. Oxford: Blackwell.

Gagarin, M. (2007), "Background and origins: oratory and early rhetoric”, in Worthington, I., A companion to Greek rhetoric. Oxford, Blackwell: 27-36.

Lévy, E. (1983), "Le théâtre et le rêve: le rêve dans le théâtre d'Eschyle", in Zehnacher, H. (ed.), Théâtre et spectacles dans l'Antiquité - Actes du Colloque de Strasbourg. Leiden, Brill: 141-168.

Martins, J. C. Oliveira (2012), "Mário de Carvalho e a reflexão metaficcional sobre o futuro do romance", in Silva, M. F., Ensaios sobre Mário de Carvalho, Coimbra, IUC: 31-53.

Pereira, S. M. (2008); "Poética dos sonhos e das visōes em estado de vigília - I", Humanitas 60: 11-28; (2009), "Poética dos sonhos e das visóes em estado de vigília - II", Humanitas 61: 5-18.

Reis, C., Macário Lopes, A. C. (2007), Dicionário de Narratologia. Coimbra: Almedina.

Silva, M. F. (2012), "A imagem literária do Tempo e da História em Mário de Carvalho”, in Silva, M. F., Ensaios sobre Mário de Carvalho, Coimbra, IUC: 13-30.

Simôes, M. J. (2012), "Sátira e o cepticismo: configuração de personagens em Mário de Carvalho", in Silva, M. F., Ensaios sobre Mário de Carvalho, Coimbra, IUC: 55-76.

Yunis, H. (2007), "Plato's rhetoric", in Worthington, I., A companion to Greek rhetoric. Oxford, Blackwell: 75-89. 


\title{
O que náo cabe nas palavras peripécia e reconbecimento em $\mathrm{Os}$ Maias
}

(What words do not contain -

peripeteia and anagnorisis in A tragédia da Rua das Flores and in Os Maias)

\author{
Jorge Deserto \\ Universidade do Porto \\ Centro de Estudos Clássicos e Humanísticos da Universidade de Coimbra \\ (jdeserto@gmail.com)
}


Página deixada propositadamente em branco 
Resumo - O objectivo, no presente trabalho, é olhar para Os Maias numa perspectiva, um tanto afastada dos caminhos mais habituais. Em primeiro lugar, ao enunciar alguns sinais que, no romance de Eça, lembram de forma clara a tragédia clássica e, dentro dela, em especial o Rei Édipo, referência fundamental, vai tecendo o seu caminho implacável. Em segundo lugar, ao tratar o modo hábil como Eça resolve o momento da revelação da verdade, ou seja, a ocasião em que alguém vê a sua vida completamente destruída por meio de uma revelação funesta. Veremos que, neste caso, as liçóes da tragédia, embora por caminhos indirectos, não se vêem completamente esquecidas.

Palavras chave - incesto, destino, reconhecimento, peripécia, A tragédia da Rua das Flores

Abstract - This article looks at Os Maias from a particular point of view. First of all, underlining some topics of classical tragedy in Eça's novel, in particular Oedipus the king, it builds its implacable progress. And then, it considers Eça's revelation of the truth, this means, the moment when someone sees his life completely destroyed by a terrible revelation. We will see that models from tragedy, taken in different ways, are not completely forgotten.

KEYwords - incestuous relations, destiny, anagnorisis, peripeteia, A tragédia da Rua das Flores.

\section{Introdução}

O que leva um leitor, nos dias de hoje, a ler Os Maias? Em condiçôes normais, não deveria ser necessário colocar esta interrogação, já que parece indiscutível estarmos diante de uma obra enorme, de um daqueles monumentos que marcam a história literária. Esperaríamos, portanto, que esta fosse uma obra procurada por todos, que naturalmente fizesse parte do património de leitura de qualquer cidadáo. No entanto, há aspectos que nos convocam a uma leitura mais fina desta questão. Antes de mais, trata-se de um romance tão amplo, com uma gama de episódios táo vasta, que os elementos que atraem cada leitor, na irredutível singularidade que subjaz a cada opção de leitura, podem ser os mais variados, nem todos sobreponíveis ou equivalentes. Afinal, este é um romance em que o "objecto de reflexão" dominante é Portugal, um romance que tem como "projecto global" o "de escrever, de explicar Portugal como problema", como afirma Jacinto do Prado Coelho (1976: 188)1. Um projecto tão amplo pode ter o condão de intimidar o leitor.

1 O mesmo autor, ao sublinhar esse largo espectro que o romance abarca, ancora-o, desde logo, num signo para-textual: tanto o título como o subtítulo se apresentam no plural (Coelho 1976: 167). 
Acresce também que, num país com um índice de leitura tấo baixo, a aproximação a Os Maias assume-se, muitas vezes, não como um percurso natural, mas como um obstáculo que se torna necessário ultrapassar. A tudo isto vem juntar-se o papel da escola. Todos os estudantes portugueses que completam o secundário estudam, nas aulas de Português, Os Maias, ou melhor, na maioria dos casos, contornam Os Maias. Nasce aí, frequentemente, uma relaçáo de amor/ódio (em alguns casos, de ódio/ódio) que o tempo não consegue resolver. Em muitos casos, o ensino de Os Maias no secundário redunda numa espécie de ficção, na qual os alunos fingem que leram a obra e os professores tentam desesperadas estratégias para tornar produtivo esse acto de não-leitura. A estrutura episódica da obra acaba por colaborar com esse intento, já que permite a concentração em alguns passos isolados, por regra aqueles que constroem uma imagem irónica da sociedade portuguesa da segunda metade do século XIX: o confronto entre a educação vigorosa de Carlos e a formação tradicional de Eusebiozinho na infância de Santa Olávia, o jantar do Hotel Central, as corridas no hipódromo de Belém, o sarau no teatro da Trindade. Mais do que uma imagem de conjunto, apanham-se instantâneos, nem sempre ligados com solidez, já que não há uma leitura prévia que os una. A exploração obrigatória de uma obra densa e extensa como Os Maias congrega perigos e entrega ao entusiamo do professor a capacidade de fazer dela uma experiência inesquecível - espera-se que pelas melhores razóes. Mas o peso da obrigação ultrapassa, frequentes vezes, a energia dos docentes.

Outra qualidade de Os Maias é o modo como torna enriquecedora qualquer releitura. No processo de preparação deste trabalho, regressei, de um modo sistemático, a uma narrativa que, depois dos tempos de estudante, apenas tinha visitado de forma episódica. Este regresso revelou-me uma outra obra. O que tinha mudado, obviamente, era a minha qualidade de leitor, modificado pelo tempo, amadurecido, mais capaz de sensibilidade a pormenores que, anteriormente, não me tinham prendido a atenção. Um leitor ainda capaz de sentir a emoção que a obra desperta, mas uma emoçáo que agora mais densamente se mistura com a experiência pessoal, feita de ilusóes que o tempo foi erodindo, de expectativas e certezas que a vida foi amaciando, tornando-me, por exemplo, mais sensível ao fracasso daquelas figuras que pretendiam mudar o mundo e que terminam, prosaicamente, a correr atrás de um jantar. Mas é certo que uma obra-prima se define também por esta capacidade de nos permitir que nos leiamos enquanto a lemos: na medida deste critério, Os Maias são, indiscutivelmente, uma obra-prima. 


\section{O que não cabe nas palavras \\ peripécia e reconhecimento em $\mathrm{Os}$ Maias}

Em suma, entre a obrigação e o prazer, entre o cânone e a descoberta, livre e ausente de preconceitos, Os Maias oferecem vários caminhos para um acesso que será sempre uma recompensa. Embora suspeitemos que a este romance caberá muitas vezes aquele lugar, reservado a tantas outras obras maiores da História da Literatura (de Homero, Virgílio e Camóes a Dante ou a Goethe, de Herculano a Garrett ou Camilo, de Proust ou Joyce a Melville ou a Thomas Mann), o lugar onde se arrumam os textos que todos sabemos que devíamos ler, mas que, por variadas razóes e ainda mais variadas desculpas, acabamos efectivamente por não ler.

O meu objectivo, no presente trabalho, é olhar para Os Maias numa perspectiva, em nada inédita, mas um tanto afastada dos caminhos mais habituais. Em primeiro lugar, ao enunciar alguns sinais que, no romance de Eça, lembram de forma clara a tragédia clássica e, dentro dela, em especial o Rei Édipo, referência fundamental - em particular no modo como trabalha a presença de destino, essa força invisível que, na sombra, à revelia da cegueira das personagens, vai tecendo o seu caminho implacável. Em segundo lugar, ao tratar o modo hábil (num sentido que poderia evocar o dexios aristofânico) como Eça resolve o momento da revelaçáo da verdade, ou seja, como resolve a dificuldade de colocar em palavras (e, mais ainda, nas palavras de um narrador) a ocasião em que alguém vê a sua vida completamente destruída por meio de uma revelação funesta. Veremos que, neste caso, as liçôes da tragédia, embora por caminhos mais indirectos, não se vêem completamente esquecidas.

\section{Tragédia: família, incesto, destino}

De entre as muitas razóes que podem levar um leitor a escolher Os Maias como companheiro de viagem, a primeira delas não será, certamente, aquela que nos alerta para a presença neste romance de algumas das características habitualmente associadas à tragédia da antiguidade. No entanto, a dimensão trágica desta intriga, como tem sido já abundantemente sublinhado, é algo de extremamente relevante, seja no que se prende com a sua dimensão de história familiar, seja no que respeita aos amores incestuosos de Carlos e Maria Eduarda, seja no que concerne à força, inalterável e inamovível, do destino. O leitor facilmente encontra ecos de temas que está habituado a considerar quando se debruça, por exemplo, sobre a tragédia grega. Estes apontam, em particular, para ressonâncias de uma obra como o Rei Édipo, o que nâo deve propriamente surpreender-nos, tendo em conta o papel para- 
digmático que a peça de Sófocles foi garantindo ao longo do tempo, ao qual não será alheia a valoração positiva que sobre ela recai na leitura da tragédia que Aristóteles faz na sua Poética.

Entre os aspectos que dão forma a esta leitura, avultam alguns que se impõem de um modo particularmente evidente. Em primeiro lugar, a forma como o romance se assume como uma história de família, claramente denunciada pelo título principal. Os contornos trágicos, como se compreende, não estáo neste puro acto enunciativo: mas já estáo bem presentes no desenvolvimento da acção, na qual um acontecimento trágico, que ensombra uma determinada geração da família, vai alastrar, como uma mancha imparável e incontrolável, à geração seguinte, vítima inocente de algo que começou a ser tecido no tempo dos seus pais. O leitor familiarizado com as intrigas da antiguidade não pode deixar de pensar na história dos Pelópidas ou dos Labdácidas, nas quais também o sangue e o sofrimento se transmitem de geração em geração, numa vertigem imparável e, muitas vezes, incompreensível para os mortais, demasiado vulneráveis na sua fragilidade. O caso da casa de Tebas, como já foi dito antes, é aquele que permite o paralelo mais perfeito, já que, como Édipo, Carlos é claramente vítima de uma situação que, decorrendo do comportamento dos pais, em nada é sua responsabilidade. Esta dimensão de maldição familiar, na qual o sofrimento ameaça sucessivamente geraçóes da mesma família, deixa bem evidente a sua presença no romance de Eça.

Em segundo lugar, é forçoso referir, como motivo central da intriga romanesca - e aquele que lhe confere dimensão trágica - o incesto involuntário. Podemos dizer que este avulta como o motivo trágico por excelência, se nos lembrarmos da centralidade do Rei Édipo - e da sua recepção - na tragédia antiga e no modelo de trágico que Eça tem em mente. No espírito do autor, este tema parece incluir-se num conjunto mais vasto de costumes e paixôes a analisar e dissecar no tecido social português. Em carta ao editor, datada de Novembro de 1877, apresenta o plano daquilo a que, neste momento, chama Crónicas da Vida Sentimental (apud Lima 1987: 199):

Para produzir, porém, um alto grau de interesse - é necessário dar-lhes diversidade. Assim, alguns (volumes) pintarão costumes gerais da nossa sociedade: $O$ Prédio $n^{o} 16$ será o jogo; $A$ Linda Augusta, a prostituição; $O$ Bacharel Sarmento, a educação e as escolas, etc. Outros, serão o estudo de alguma paixão ou drama excepcional: assim $A$ Genoveva é o incesto; Soror Margarida, a monomania religiosa; teremos ainda $O$ 


\section{O que não cabe nas palavras \\ peripécia e reconhecimento em $\mathrm{Os}$ Maias}

Milagre de Vale de Roriz, para mostrar o fanatismo das aldeias; O Bom Salomão dar-nos-á a agiotagem, etc.

O primeiro volume está muito adiantado; hesito: talvez O Desastre $d a$ Rua das Flores, talvez Os Amores de uma Linda Moça. Em todo o caso é o incesto...

Não é difícil partilhar a perplexidade de Isabel Pires de Lima, quando assinala que Eça refere o incesto "como se este fosse um mal social tão generalizado e com tal dimensão entre nós, quanto os outros que ele projecta retratar - o jogo, a prostituição, o fanatismo religioso, a agiotagem, o adultério." (Lima 1987: 199-200). A questão atenua-se se, na linha do pensamento da mesma autora - e de outros que cita, nas páginas seguintes - conferirmos ao incesto uma leitura distinta, que o remete para um valor matricial de extracção literária, fundando uma actualização, nem sempre pacífica, de um modelo claramente clássico, o da tragédia. Voltarei a este tema mais adiante, quando houver ensejo de fazer uma breve comparação entre Os Maias e A tragédia da Rua das Flores. Sirva para já de conclusão a afirmação de que este motivo parece funcionar aqui como gatilho inspirador, à volta do qual se ergue toda a intriga amorosa de Os Maias.

Um terceiro aspecto relevante é o papel que o destino ocupa nesta intriga. Este é um ponto particularmente perturbador, já que esta presença de um elemento do qual está ausente toda a racionalidade não pode deixar de surpreender num romance no qual, ainda que mitigados, são visíveis sinais da presença de princípios do Naturalismo. No entanto, para lá de questóes como a influência da educaçáo ou do meio social (a que o romance náo deixa de dar copioso relevo), há, ao longo da obra, a noção de que uma força, largamente fora do controlo das personagens, trabalha na sombra para que, inevitáveis e irreparáveis, se combinem todos os fios que conduzem ao tremendo desenlace. A presença dessa força, irracional, fora de toda a capacidade de compreensão, limita a possibilidade de os homens serem senhores das rédeas que comandam o seu percurso e expóe claramente as fraquezas de quem se julga senhor de razão e entendimento superiores. Igualmente aqui o paralelo com a tragédia grega, e com o Rei Édipo em particular, se torna novamente relevante: também na obra de Sófocles há uma força invisível e incontrolável que empurra Édipo na direcção do destino que lhe está reservado, com o toque adicional de, no caso do filho de Laio, todos os seus esforços para fugir dessa força se revelarem, afinal, passos que o encaminham para ela - este é um ponto que Carlos, imerso no seu constantemente invocado diletantismo, não poderia seguir. Mas, num e noutro caso, há um aspecto fundamental que se repete e fica evidente com 
clareza - há forças que os seres humanos nitidamente não dominam e que, na sombra, conduzem muito da sua vida. A dúvida que isto lança sobre a capacidade de autodeterminaçáo do ser humano constitui, no caso de Eça, um tópico que não pode deixar de ser lido com uma certa surpresa.

Esta presença do destino aparece, antes de mais, em forma de moldura, deslocada das personagens para as paredes do Ramalhete. A forma como o próprio Vilaça, num íntimo debate entre superstição e racionalismo, apresenta a fama daquela casa (imediatamente desvalorizada por Afonso da Maia) é indiciadora de uma desconfiança que não consegue largar, mesmo sabendo-o alheio ao ar do tempo, o apego a uma tradição de lendas e agoiros tradicionais.

... e por fim [Vilaça] aludia mesmo a uma lenda, segundo a qual eram sempre fatais aos Maias as paredes do Ramalhete, «ainda que (acrescentava ele numa frase meditada) até me envergonho de mencionar tais frioleiras neste século de Voltaire, Guisot e outros filósofos liberais...» Afonso riu muito da frase, e respondeu que aquelas razóes eram excelentes - mas ele desejava habitar sob tectos tradicionalmente seus; se eram necessárias obras, que se fizessem e largamente; e enquanto a lendas e agoiros, bastaria abrir de par em par as janelas e deixar entrar o sol. (Cap. 1)

Mas a verdade é que, no final, depois da morte de Afonso, o próprio Vilaça pode regressar, sem sobressaltos racionais, à demonstração da justeza dos seus receios:

E voltando-se para o Ega, que se sentara, ainda todo pálido, no sofá bordado a matiz, antigo lugar de D. Diogo, [Vilaça] murmurou devagar, gravemente:

- Há três anos, quando o Sr. Afonso me encomendou aqui as primeiras obras, lembrei-lhe eu que, segundo uma antiga lenda, eram sempre fatais aos Maias as paredes do Ramalhete. O Sr. Afonso da Maia riu de agouros e lendas... Pois fatais foram! (Cap. 17)

Esta referência à fatalidade das paredes do Ramalhete - que confere à casa um estatuto de quase personagem - derrotando uma visão racional que, no momento inicial, parecia claramente vencedora, emoldura, como já sublinhei, na sua irrepreensível construção em anel, todo um outro conjunto de referências que apontam para a teia invisível que vai rodeando as 


\section{O que não cabe nas palavras \\ peripécia e reconhecimento em $\mathrm{Os}$ Maias}

personagens, mantendo-as na ignorância ou mesmo embaladas num doce e cego engano.

Mesmo quando se trata ainda dos amores entre Pedro da Maia e Maria Monforte, há já sinais desta temática. Atente-se, por exemplo, no momento em que Afonso, na companhia de Sequeira, vê, pela primeira vez, Pedro na companhia da filha do negreiro:

O Sequeira ficara com a chávena de café junto aos lábios, de olho esgazeado, murmurando:

- Caramba! É bonita!

Afonso não respondeu: olhava cabisbaixo aquela sombrinha escarlate, que agora se inclinava sobre Pedro, quase o escondia, parecia envolvê-lo todo - como uma larga mancha de sangue alastrando a caleche sob o verde triste das ramas. (Cap. 1)

Para lá do valor simbólico daquela sombrinha escarlate, notória premonição do desenlace trágico daquela relaçáo, o leitor familiarizado com o mundo clássico não resistirá a associar aquela "larga mancha de sangue" 2 que alastra à noção de miasma, a mancha poluidora que, ao espalhar-se, contamina todos aqueles que com ela contactam. Não é completamente deslocado, igualmente, que evoquemos a mancha vistosa dos tapetes cor de púrpura que, em Ésquilo, o Agamémnon da tragédia homónima pisa com arrogância, desafiado por Clitemnestra. Também aquela mancha que alastra da boca da casa prenuncia o sangue derramado pelo rei de Argos, prestes a sofrer uma violentíssima morte.

Quando o romance nos narra os amores de Carlos e Maria Eduarda, encontramos uma multiplicaçáo destes sinais. Logo no momento do nascimento de Carlos, a escolha do nome por parte da máe, influenciada pela leitura de um romance, parece trazer consigo um selo fatal:

Para abrandar desde já o papá, Pedro quis dar ao pequeno o nome de Afonso. Mas nisso Maria não consentiu. Andava lendo uma novela de que era herói o último Stuart, o romanesco príncipe Carlos Eduardo; e, namorada dele, das suas aventuras e desgraças, queria dar esse nome a seu filho... Carlos Eduardo da Maia! Um tal nome parecia-lhe conter todo um destino de amores e façanhas. (Cap. 2)

2 O próprio texto retoma a referência e confirma o seu valor simbólico e premonitório. No mesmo capítulo 1, Afonso encontra o filho, que acaba de suicidar-se, "aos pés da cama, caído de bruços, numa poça de sangue que ensopava o tapete." 
Parece um pormenor de nula importância, mas, ao impedir que o bebé tenha o nome de Afonso, há algo que, desde o início, afasta este rapaz de um legado que a solidez do nome do avô, ligado ao carácter forte e severo do patriarca, lhe poderia garantir.

À medida que o romance avança, à medida que vai ganhando forma a aproximação entre Carlos e Maria Eduarda, continuam a surgir sinais de que o destino vai traçando o seu caminho, iludindo as personagens com sinais a cujo significado a sua natural cegueira não permite aceder. De um grupo muito amplo, que poderia multiplicar-se quase infindamente, sublinho alguns nos quais essa cegueira se torna particularmente evidente. Vejase, em primeiro lugar, o momento em que Carlos pela primeira vez sabe o nome daquela mulher que tanto o tinha impressionado:

- Tenha V. Ex. ${ }^{a}$ a paciência de esperar um instantinho que eu vou dar parte à Sr. ${ }^{a}$ D. Maria Eduarda...

Maria Eduarda! Era a primeira vez que Carlos ouvia o nome dela; e pareceu-lhe perfeito, condizendo bem com a sua beleza serena. Maria Eduarda, Carlos Eduardo... Havia uma similitude nos seus nomes. Quem sabe se não pressagiava a concordância dos seus destinos! (Cap. 11)

A proximidade entre os nomes, esse ilusório elo, é, afinal, o símbolo de uma ligação mais profunda, que Carlos não poderia antecipar. Ao mesmo tempo, a teia do destino, ao afastar a Gouvarinho e Dâmaso, ambos ausentes em inesperadas viagens, parece dar a Carlos todo o espaço de que ele precisa para a sua conquista. E, mais uma vez, o vemos a saborear o presente envenenado do acaso com a alegria dos que desconhecem as consequências:

Carlos, só, dentro do coupé, voltando à Baixa, sentia uma alegria triunfante com aquela partida da condessa, e a inesperada jornada do Dâmaso. Era como uma dispersáo providencial de todos os importunos: e assim se fazia em torno da rua de S. Francisco uma solidão - com todos os seus encantos, e todas as suas cumplicidades. (Cap. 11)

Quando a relação ganha força e os dois amantes se instalam na "Toca”, também o quarto que lhes está reservado, com a sua decoração excessiva, se enche de sinais de agouro - para lá do mau gosto, sentimos no ar, palpável, a ameaça: 


\section{O que não cabe nas palavras \\ peripécia e reconhecimento em $\mathrm{Os}$ Maias}

Mas depois o quarto que devia ser o seu, quando Carlos lho foi mostrar, desagradou-lhe com o seu luxo estridente e sensual. Era uma alcova, recebendo a claridade duma sala forrada de tapeçarias, onde desmaiavam na trama de lá os amores de Vénus e Marte. (...) Mas Maria Eduarda não gostou destes amarelos excessivos. Depois impressionou-se, ao reparar num painel antigo, defumado, resultando em negro do fundo de todo aquele ouro - onde apenas se distinguia uma cabeça degolada, lívida, gelada no seu sangue, dentro dum prato de cobre. E para maior excentricidade, a um canto, de cima de uma coluna de carvalho, uma enorme coruja empalhada fixava no leito de amor, com um ar de meditação sinistra, os seus dois olhos redondos e agourentos... Maria Eduarda achava impossível ter ali sonhos suaves. (Cap. 13)

A cabeça degolada no painel, os olhos sinistros da coruja lançam uma sombra evidente sobre aquele momento idílico; apesar da ignorância das personagens, percebemos que algo contamina aquele ninho de amor. Quando, mais adiante, Maria Eduarda visita o Ramalhete, novamente os sinais desafiam a cegueira dos intervenientes:

Aqueles lindos cuidados fizeram-na sorrir, enternecida. Depois reparou no retrato de Pedro da Maia: e interessou-se, ficou a contemplar aquela face descorada, que o tempo fizera lívida, e onde pareciam mais tristes os grandes olhos de árabe, negros e lânguidos.

- Quem é? - perguntou.

- É meu pai.

Ela examinou-o mais de perto, erguendo uma vela. Não achava que Carlos se parecesse com ele. E voltando-se muito séria, enquanto Carlos desarrolhava com veneração uma garrafa de velho Chambertin:

- Sabes tu com quem te pareces às vezes?... É extraordinário, mas é verdade. Pareces-te com minha mãe!

Carlos riu, encantado duma parecença que os aproximava mais, e que o lisonjeava.

- Tens razão, disse ela, que a mamã era formosa... Pois é verdade, há um não sei quê na testa, no nariz... Mas sobretudo certos jeitos, uma maneira de sorrir... Outra maneira que tu tens de ficar assim um pouco vago, esquecido... Tenho pensado nisto muitas vezes... (Cap. 14)

O encanto de Carlos diante das semelhanças enunciadas é, talvez, o mais eloquente exemplo de algo que podemos associar à noçáo de ironia 
trágica, esse evidente descaso entre aquilo que as personagens percebem e o fundo mais negro que, enquanto leitores, começamos a entender.

A acumulação de exemplos, talvez mais extensa do que recomendaria o bom senso, ilustra de um modo que me parece claro uma construçáo romanesca que, em larga medida, assenta algumas das suas traves mais importantes numa noção de acaso, constituído como uma força invisível que inevitavelmente aproxima aqueles que não deviam aproximar-se e que, movendo silenciosamente as peças, contribui para o desenlace trágico. Esta é uma concepção de destino que parece fugir a toda a racionalização. Para os antigos gregos, estes fios que comandavam a vida dos seres humanos eram tecidos por forças que estavam muito acima da efémera existência daqueles que nasciam condenados a morrer e, por isso, tais fios estavam naturalmente afastados da capacidade de compreensão dos mortais e eram inquestionáveis. No mundo de Eça, à medida que os fios entrelaçados começam a tornar-se visíveis, a força do acaso não prescinde completamente da racionalização. Tendo diante de si o quadro terrível da verdade, Ega tenta dar ordem a um mundo que, num repente, parece ter-se virado do avesso. E tenta argumentar, consigo próprio, para bem da sua própria capacidade de acomodar aquele tremendo impacto, que a teia do acaso juntou aqueles que, pela excepcionalidade, sempre naturalmente tenderiam a aproximar-se:

E pouco a pouco aquela luz viva, saída do alto, parecia ao Ega penetrar nessa intrincada desgraça, aclará-la toda, mostrar-lhe bem a lenta evolução. Sim, tudo isso era provável no fundo! Essa criança, filha duma senhora que a levara consigo, cresce, é amante dum brasileiro, vem a Lisboa, habita Lisboa. Num bairro vizinho vive outro filho dessa mulher, por ela deixado, que cresceu, é um homem. Pela sua figura, o seu luxo, ele destaca nesta cidade provinciana e pelintra. Ela por seu lado, loura, alta, esplêndida, vestida pela Laferrière, flor duma civilização superior, faz relevo nesta multidão de mulheres miudinhas e morenas. Na pequenez da Baixa e do Aterro, onde todos se acotovelavam, os dois fatalmente se cruzam: e com o seu brilho pessoal, muito fatalmente se atraem! Há nada mais natural? Se ela fosse feia e trouxesse aos ombros uma confecção barata da loja da América, se ele fosse um mocinho encolhido de chapéu de côco, nunca se notariam e seguiriam diversamente nos seus destinos diversos. Assim, o conhecerem-se era certo, o amarem-se era provável... (Cap. 16)

É ainda o acaso, um acaso ao qual não falta força demiúrgica, capaz de destruir aqueles sobre quem recai, mas um acaso regulado pelas proba- 


\section{O que não cabe nas palavras \\ peripécia e reconhecimento em $\mathrm{Os}$ Maias}

bilidades, um acaso ao qual uma luz de raciocínio vem colocar uma certa ordem. Como se as forças do destino, mesmo se incertas e incontroláveis, se deixassem iluminar por alguma luz e, por serem, apesar de tudo, explicáveis, se tornassem menos obscuras. De algum modo, também o destino se deixa ler por matrizes de natureza social e cultural e, nesse transe, se torna menos ameaçador. Pelo menos, Ega deixa-se repousar nessa explicação, como se os acontecimentos, diante da lógica de um raciocínio, amortecessem o seu peso ameaçador.

De todos os modos, e é este o meu ponto na primeira parte deste artigo, Eça constrói Os Maias como uma intriga trágica largamente devedora de um modelo de tragédia que assenta, largamente, sobre os ombros do Rei Édipo de Sófocles. Seja pela escolha do incesto como motivo do desenlace trágico, seja pela forma como torna Carlos e Maria Eduarda vítimas de um destino que trabalha para os perder, numa intriga em que os erros da geração dos pais vão recair sobre os filhos que cegamente os ignoram. $\mathrm{O}$ destino final de ambos, assim o ditam os tempos e as circunstâncias, não será tão terrível como o de Édipo ou Jocasta. Mas Carlos embarca também para um exílio purificador, do qual regressará episodicamente para contemplar uma Lisboa que não se moveu desde a sua partida. Resta-lhe um vazio que alimenta à força de dinheiro e de interesses fúteis - e essa tragédia, que largamente interessa a Eça, já não tem a ver com o seu amor impossível, essa é a tragédia de uma geração que desistiu de mudar o mundo e se acomodou às suas imperfeiçóes.

Ainda uma nota, antes de passar ao tema seguinte. A tragédia, para cumprir perfeitamente o seu efeito emocional, necessita de concentraçáo, precisa de centrar-se numa acção e de explorá-la de modo a que o espectador ou o leitor não se alheiem e não sejam desviados por outros apelos. Ora, neste romance Eça opta por uma estratégia de diluição, ao constantemente interromper o desenvolvimento da intriga trágica com múltiplos episódios, normalmente carregados de feroz ironia, ao multiplicar as personagens, impedindo que o leitor se prenda apenas àquela teia que vai construindo a aproximaçáo dos dois irmãos e o seu caminho para a revelação de uma terrível verdade. Estes constantes desvios, esta estratégia de mitigação, embora atenuada nos momentos finais, não deixa de estar sempre presente, como é facilmente observável através do episódio cómico do chapéu que Vilaça teima em náo encontrar, que vem quebrar o momento em que avô e neto lidam com a mais terrível das revelaçóes. Eça parece dizer-nos que, nestes tempos contemporâneos, a tragédia se dilui nos vários acontecimentos da vida e não se pode esperar que ela surja, intocada e isenta de contaminação. 
Que, mesmo assim, guarde, como o comprovará qualquer leitor do romance, um poderoso efeito emocional, eis algo que teremos de creditar ao génio do autor da obra.

\section{A revelaçáo da verdade}

$\mathrm{O}$ mais poderoso momento de qualquer intriga de incidência trágica é aquele em que as personagens se vêem, finalmente, diante do poder de uma terrível verdade, até aí desconhecida, que se prepara para mudar completamente o curso das suas vidas. Estes momentos, a que Aristóteles, na Poética, chama peripécia ("a mudança dos acontecimentos para o seu reverso" - 1452a; Valente 2004: 57) e reconhecimento ("passagem da ignorância para o conhecimento, para a amizade ou para o ódio entre aqueles que estão destinados à felicidade ou à infelicidade" - idem, ibidem) são, para o Estagirita, pilares fundamentais na construção de qualquer enredo. E são, igualmente, os momentos mais poderosos em termos emocionais. Todos sabemos como, no Rei Édipo, é extremamente forte todo aquele quarto episódio, no qual Édipo, diante do servo que, em criança, o abandonara, tentando salvá-lo da morte, ouve finalmente as palavras que desvendam toda a sua origem e a enormidade daquilo que o destino para ele traçara. Ouvir a mais funesta das revelaçóes e reagir a ela são momentos delicados, difíceis de colocar em palavras. É exactamente dessa dificuldade que pretendo falar aqui.

Também Eça parece tê-la sentido agudamente. A nossa leitura pode tornar-se mais clara se tentarmos uma breve comparação entre as soluçốes encontradas em A tragédia da Rua das Flores e n' Os Maias. Esta comparação, com todas as suas falhas, particularmente as que decorrem do distinto grau de aperfeiçoamento das duas obras, pode tornar mais evidente a qualidade da soluçáo que o romancista encontra, em Os Maias, para ultrapassar este obstáculo.

Convém sublinhar, previamente, que não pretendo deter-me aqui em toda a polémica que rodeou a divulgação pública de $A$ tragédia da Rua das Flores. Não é meu propósito discutir até que ponto foi sensato dar à estampa uma obra que o autor não trabalhou até ao fim e que, por isso, apresenta sinais evidentes de estar longe da qualidade de outras obras de Eça. A tragédia da Rua das Flores interessa-me apenas pelo modo como esta obra nos pode oferecer um vislumbre de uma etapa num processo criativo que, em Os Maias, é alvo de um aturadíssimo labor. 


\section{O que não cabe nas palavras \\ peripécia e reconhecimento em $\mathrm{Os}$ Maias}

Parece indiscutível que $A$ tragédia da Rua das Flores se apresenta como uma primeira tentativa de Eça lidar com o tema trágico do incesto, sempre na esteira da abordagem sofocliana no Rei Édipo. Que o incesto está no centro da preocupação do autor, pode depreender-se de alguns testemunhos do próprio autor, como já vimos anteriormente e pode confirmar-se nos exemplos seguintes. O primeiro, em carta ao editor, um mês antes da citada anteriormente (apud Matos 1988a: 604)

«...uma das novelas está pronta - é só copiá-la: chama-se o Desastre da Travessa do Caldas - ou talvez, não sei ainda: $O$ caso atroz de Genoveva. Trata-se de um incesto. Dará, creio eu, 200 páginas, ou mais. Alguns amigos a quem comuniquei a ideia dela, e parte da execução, ficaram impressionados, ainda que um pouco escandalizados. Não quero dizer que seja imoral ou indecente. É cruel.»

O segundo, quase um ano depois, em carta a Ramalho Ortigão (apud Matos 1988a: 604):

«Eu tenho justamente um romance que estava à espera de vez: escrevi-o para ser a primeira parte das Cenas, mas além de ser mais volumoso do que o plano das cenas comporta (atinge quase a obesidade do Primo Basílio), não me servia artisticamente como introdução às Cenas. Foi por isso que o substituí pela Capital, que é mais um trabalho de generalidade. $\mathrm{O}$ assunto é grave - incesto; mas tratado com tanta reserva que não choca. Os Amores de um Lindo Moço, título pretensiosamente medíocre. Poderei, pour la circonstance, chamar-lhe: O Brasileiro; o herói é-o. Como arte tem tipos de que gosto - tratados numa nova maneira, a contornos grossos, de forte destaque; incidentes curtos, muito adaptáveis ao folhetim - enfim, o que justamente convém.»

Para lá das hesitaçóes incessantes acerca do título - note-se, no entanto, como parece fugir ao termo 'tragédia' - parece fora de dúvida que o romancista constrói esta intriga à volta de um pilar fundamental, o incesto. Aliás, para estar ainda mais próximo do modelo clássico, trata-se do incesto involuntário entre mãe e filho, ou seja, segue mais de perto as pisadas sofoclianas. Quando chegamos a Os Maias, Eça cria a intriga à volta de dois irmáos, o que, desde logo, anula qualquer espécie de implausibilidade quanto à diferença de idades. Além disso, ao afastar a família Maia de qualquer espécie de dificuldade em termos financeiros, ficam também obliteradas 
todas as questôes materiais que jogavam um papel relevante no enredo de A tragédia... e que lhe conferiam um grau de sordidez que Eça resolve atenuar francamente, conferindo às suas personagens uma elevação que torna mais clara a sua inocência de vítimas de um destino, sem para ele contribuírem com qualquer espécie de mancha. Também aqui, ao lidar, na versão posterior, com personagens elevadas, se aproxima mais dos postulados da tragédia clássica.

É também este aperfeiçoamento de rugosidades, em termos de técnica narrativa, que está presente no momento que particularmente me interessa. Em A tragédia da Rua das Flores, o momento em que Genoveva sabe a verdade, em directo confronto com Timóteo da Ega, tio de Vítor, é colocado diante dos nossos olhos em toda a sua crueza (Queirós 1980: 450-451)

- De onde é, donde? - perguntou Timóteo; respirava com aflição, e a bengala tremia-lhe na mão extraordinariamente.

- Sou da Guarda - disse ela.

Timóteo estacou, imóvel, com os olhos dilatados, murmurou duas vezes:

- Santo nome de Deus! Santo nome de Deus!

- O que é? - fez ela lívida.

- Seu marido? Quem era? (...)

-Porquê? Meu marido? Chamava-se Pedro da Ega.

-Oh, maldita! Maldita! Maldita! - bradou Timóteo. E os seus braços erguidos tinham um tremor, o olhar alucinado, e com uma voz estrangulada, medonha:

- Mas esse homem é Vítor da Ega! É seu filho! Eu sou Timóteo da Ega. Ela levou as máos à cabeça, com um gesto medonho: os olhos saíam-lhe das órbitas, a boca aberta queria gritar; começou a torcer as mãos: a sua trança soltou-se: levou os dedos convulsivamente ao colar, a mola desprendeu-se; e, dando passos vagos pela sala, com sons roucos e terríveis, os braços altos, batendo o ar - foi cair sobre o tapete, com os braços abertos.

A verbalização da verdade, a reacção da Genoveva, a tudo assistimos e, perante nós, a visível dificuldade de as palavras traduzirem o momento que as personagens vivem. $\mathrm{O}$ tremor, o olhar alucinado, medonho, o gesto medonho da mulher, a convulsão, tudo isto resulta simultaneamente pobre e excessivo. Mais adiante, quando é confrontada por Vítor, de novo as pala- 


\section{O que não cabe nas palavras \\ peripécia e reconhecimento em $\mathrm{Os}$ Maias}

vras parecem não chegar para a importância decisiva do momento (Queirós 1980: 454):

- Que é, Genoveva? - gritou, aflito, correndo para ela.

Ela viu-o e recuou, com os olhos dilatados, o corpo inteiriçado, um esgar na boca, medonha - e os seus braços faziam insistentemente sinal que náo! Não! Respirava com um aahn ansioso, de agonia. E os olhos terríveis, pasmados, como mortos, saídos das órbitas, fixavam-se nele, com uma persistência pavorosa.

(...)

E ia para ela - mas ela, abrindo a boca com uma ânsia terrível, soltou num baque súbito um grito:

Maldito! Maldito!

E, olhando num relance, correu à janela e, lançando o corpo sobre o peitoril, atirou-se, com um grito estridente. Vítor sentiu ainda o seu corpo fazer, na rua, como um som baço e mole de um fardo de roupa.

De novo o adjectivo 'medonho' parece representar o cume da representação da emoçáa. A comparaçáo final a propósito da queda do corpo na rua funciona quase como anticlímax de um momento que deveria representar, em termos narrativos, um extremo impossível de dor. As palavras ficam curtas para representar este momento, às emoçôes extremas é difícil domá-las no discurso.

Eça parece ter dado particular conta desta dificuldade. Por isso, em $O s$ Maias constrói uma solução particularmente engenhosa. A mudança de fortuna e todas as revelaçóes que se tornam, na sua sequência, necessárias, tudo isso é colocado às costas da perspectiva subjetiva de Joáo da Ega, de tal modo que nós, enquanto leitores, apenas vemos o que ele vê, apenas estamos presentes quando ele está presente. Isso acontece a partir do momento em que Guimarães revela a Ega a verdade e, poupando-nos sempre ao efeito de choque de uma revelaçáo difícil, leva-nos ao momento em que Carlos conhece a verdade e, mais adiante, à ocasião em que Maria Eduarda também sabe de tudo. Isto acontece em dois momentos distintos e também diversamente construídos.

No primeiro, que envolve Carlos, é a falta de coragem de Ega que o faz evitar contar de imediato ao amigo uma verdade que sabe terrível. Seguimos o modo como Ega luta com essa hesitação, especialmente num momento em que teme ver-se forçado pelas circunstâncias a dizer tudo: 
De resto, não poderia ele ajuntar em si bastante coragem, para contar tudo a Carlos, logo, nessa manhã, claramente, virilmente? Era por fim aquele caso tão pavoroso como lhe parecera na véspera - um irreparável desabamento de uma vida de homem?...

(...)

Justamente Carlos fora correr o transparente da janela. Aí, na mesa de trabalho, colocada em plena luz, ficara a caixa da Monforte, embrulhada no Rappel. E Ega pensou num relance: «Se ele repara, se pergunta, digo tudo!» - O seu pobre coração pôs-se a bater ansiosamente, no terror daquela decisão. Mas o transparente um pouco perro subiu, uma faixa de sol banhou a mesa - e Carlos voltou sem reparar no cofre. Foi um imenso alívio para o Ega. (Cap. 17)

Ega resolve, então, que a revelação se fará através de Vilaça, dando-lhe um cunho oficial, quase burocrático. Exime-se, assim, a estar presente no decisivo momento - e poupa ao leitor a narração desse instante. Ainda temeroso, Ega chega apenas depois, 'passado o barranco', e a narrativa pode já livrar-se desse instante difícil:

E Ega pensava: - «Bem, Carlos já sabe tudo, o barranco está passado!» Mas demorou-se ainda, tirando as luvas e o paletó com uma lentidão cobarde. Por fim, sentindo bater alto o coração, puxou o reposteiro de veludo. Na ante-câmara pesava um silêncio; a chuva grossa fustigava a porta envidraçada, por onde se viam as árvores do jardim esfumadas na névoa. Ega levantou o outro reposteiro que tinha bordadas as armas dos Maias.

- Ah! és tu? - exclamou Carlos, erguendo-se da mesa de trabalho com uns papéis na mão.

Parecia ter conservado um ânimo viril e firme: apenas os olhos lhe rebrilhavam, com um fulgor seco, ansiosos e mais largos na palidez que o cobria. Vilaça, sentado defronte, passava vagarosamente pela testa, num movimento cansado, o lenço de seda da Índia. Sobre a mesa alastravam-se os papéis da Monforte.

(...)

- Que diabo de embrulhada é esta que me vem contar o Vilaça? - rompeu Carlos, cruzando os braços diante de Ega, numa voz que apenas de leve tremia.

Ega balbuciou: 
- Eu não tive coragem de te dizer...

- Mas tenho eu para ouvir!... Que diabo te contou esse homem? (Cap.17)

É já no refluxo da exposição da verdade que Eça leva o seu leitor a defrontar a reacção de Carlos. Como acontece ao longo do romance, o tempo atmosférico contribui para sublinhar a dificuldade do momento. Mas já não é preciso aos adjectivos atropelarem-se e repetirem-se. De facto, o barranco está passado, e agora é já a razão que quer perceber o inominável que está a acontecer. Ainda assim, o leitor que recorde o texto de Sófocles náo pode deixar de notar aqui um eco, bem claro, na troca de palavras entre Ega e Carlos. Quando o Servo está prestes a dizer as palavras que desvendam a verdade, este e Édipo trocam as seguintes palavras (1169-70):

$\Theta \mathrm{E}$.

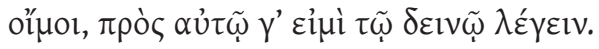

OI.

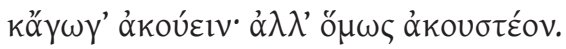

SERVO: Ai de mim, estou perante o mais terrível de dizer! ÉDIPO: E eu de ouvir, mas, ainda assim, tem de ser ouvido.

Édipo e Carlos juntam-se, assim, na mesma busca pela verdade. Quando a conhecem, não vão usar do mesmo modo esse conhecimento. Carlos insiste numa intimidade que sabe ilícita, afunda-se na vergonha dos seus actos, vê o desgosto conduzir o avô à morte. De algum modo, é essa a verdadeira tragédia, o desabar do pilar que, desde o início, nos é apresentado como o alicerce da família Maia.

Finalmente, também Maria Eduarda deverá conhecer a verdade. É igualmente Ega que se encarrega dessa difícil diligência. E, uma vez mais, quando Ega coloca os documentos diante dela, o leitor é poupado ao efeito tremendo da revelação:

...V. Exc. ${ }^{a}$ conhece a letra de sua mãe. É dela esta letra, não é verdade? - É! - exclamou Maria, indo arrebatar o papel.

- Perdão! - gritou Ega, retirando-lho violentamente - Eu sou um estranho! E V. Exc. a náo se pode inteirar de tudo isto enquanto eu não sair daqui.

Fora uma inspiraçáa providencial, que o salvava de testemunhar o choque terrível, o horror das coisas que ela ia saber. E insistiu. 
Deixava-lhe ali todos os papéis que eram de sua mãe. Ela leria, quando ele saísse, compreenderia a realidade atroz... (Cap. 17)

Esta "inspiração providencial" - que quase suspeitamos ser desabafo do próprio Eça, hábil narrador, diante de uma solução feliz - salva-nos também a nós, leitores, de testemunhar o choque, o horror. De algum modo, deixa à nossa imaginação o que se terá passado em seguida, estimula-a, evitando que um momento como aquele seja cercado por palavras que ficariam sempre aquém do verdadeiro sofrimento que pretenderiam traduzir. Ao compararmos esta solução com aquela que Eça havia encontrado em A tragédia da Rua das Flores, percebemos como, no romance posterior, se chega a uma construçáo mais hábil e conseguida. De facto, há momentos em que as palavras, pura e simplesmente, podem estar a mais.

A tragédia grega não é avessa à exposição do sofrimento. Ainda assim, no caso que nos serve aqui de referência - como terá servido a Eça -, após a revelação, Édipo retira-se de cena e tomamos conhecimento dos terríveis acontecimentos seguintes através do relato de um mensageiro que sai do palácio. Há aqui um efeito de mediação, que nos prepara para o surgimento de Édipo no final. Numa linha afim, ainda que sejam também indiscutíveis as diferenças, também Eça decide poupar-nos à narração de um conjunto de momentos nos quais as palavras, por mais trabalhadas que sejam, parecem sempre ser incapazes de desenhar o extremo das emoçóes. Esta habilidade de narrador consumado (que poderíamos, como já disse, aproximar à dexiotes aristofânica) não é coisa menor entre a imensa variedade de apelos que devem continuar a atrair-nos para a leitura de Os Maias. 
O que não cabe nas palavras

peripécia e reconhecimento em Os Maias

\section{Bibliografia}

Coelho, J. P. (1976), "Para a compreensão de Os Maias como um todo orgânico", in Ao contrário de Penélope. Lisboa, Bertrand: 167-188.

Lima, I. P. (1987), As máscaras do desengano. Para uma abordagem sociológica de Os Maias de Eça de Queirós. Lisboa: Caminho.

Luzes, P. (1988), "Incesto fraternal”, in Matos 1988: 346-348.

Matos, A. C. (1988a), “A tragédia da Rua das Flores”, in Matos 1988: 603-606.

Matos, A. C. (org.) (1988), Dicionário de Eça de Queirós. Lisboa: Caminho.

Queirós, E. (1976), Os Maias. Lisboa: Círculo de Leitores.

Queirós, E. (1980), A tragédia da Rua das Flores. Lisboa: Moraes Editores.

Reis, C. (1999), Estudos Queirosianos. Ensaios sobre Eça de Queirós e a sua obra. Lisboa: Presença.

Reis, C. (2009), Eça de Queirós. Lisboa: Ediçōes 70.

Sousa, A. G. (1988), “O incesto n’ Os Maias”, in Matos 1988: 348-351. 
Página deixada propositadamente em branco 


\title{
A presença dos gregos no pensamento bermenêutico de M. Baptista Pereira
}

(Greek presence in Miguel Baptista Pereira's philosophical thought)

\author{
Maria Luísa Portocarrero Ferreira da Silva \\ Universidade de Coimbra \\ (mlp600@gmail.com)
}


Página deixada propositadamente em branco 
Resumo - Este texto procura pensar a presença decisiva do pensamento filosófico grego na filosofia hermenêutica de M. Baptista Pereira, sabendo no entanto que a sua filosofia sofre uma influência decisiva da filosofia cristá.

Palavras-Chave - valorização do núcleo socrático da filosofia grega; crítica ao modelo metódico moderno do sentido do filosofar; interpretaçáo do diálogo Íon de Platão.

Abstract - This text tries to think the decisive presence of Greek philosophical thought in philosophical hermeneutics of M. Baptista Pereira, knowing however that their philosophy suffers a decisive influence of Christian philosophy.

KEYwORDs - Appreciation of the core of Socratic Greek philosophy; critique of modern methodical philosophizing; Plato's dialogue Ion interpretation.

I-

Foi M. Baptista Pereira, saudoso professor desta Universidade, quem introduziu a Hermenêutica Filosófica nos curricula do curso de Filosofia de Coimbra. Profundamente crítico do saber morto, repetitivo e doxográfico que se transmite, como um conteúdo acabado, sem qualquer questionamento vivo e assim abafa toda a possível novidade e originalidade em Filosofia, Baptista Pereira sempre perseguiu, nas suas aulas e reflexóes, a pergunta originária por detrás dos textos e juízos formulados. Neste sentido, fomentou o diálogo vivo com a tradição, diálogo que a Hermenêutica filosófica de H.-G. Gadamer procurava já ressuscitar, como o verdadeiro método da filosofia. O lugar em que surge e se torna problemática a questão do sentido da vida é para o filósofo de Coimbra o diálogo interior que se abre às grandes questōes que sempre motivaram o filosofar e que assim se deixa fecundar pelas respostas da tradição.

É, de facto, a partir do diálogo da consciência consigo mesma, de raiz grega, que se póe, para M. Baptista Pereira, a questáo filosófica do sentido. Podemos dizer que toda a sua filosofia perseguiu esta questão ${ }^{1}$, em diálogo com a história da filosofia, numa multiplicidade de escritos de que se prepara agora a edição das obras completas.

1 A questão do sentido último da vida parece-nos ser o problema filosófico central da sua obra referida à existência enquanto decurso que se estende do nascimento até à morte e ainda à problemática do significado da temporalidade. Podemos dizer que esta grande questão aparece ainda ligada à ideia de um significado para a vida e, depois, numa linha mais reflexiva, manifesta-se como capacidade de examinar e julgar criticamente a vida. 
Foi pois o acesso interrogativo ao sentido, mediado pela dialética pergunta-resposta e recebido da tradição platónico-agostiniana, que o Professor sempre quis realçar nos seus escritos. Daí a sua dedicação à Hermenêutica filosófica e a sua crítica do ideal moderno do método marcado pela suspeita contra todo o recebido. Ao século da Hermenêutica dedicou três artigos²; dedicou ainda um a "Platấo e a hermenêutica filosófica» ${ }^{3}$ e outro ao trágico, intitulado «Sobre o Trágico» ${ }^{4}$ Vamos hoje partir destes textos e ainda de um outro artigo "Originalidade e novidade em Filosofia" ${ }^{5}$, pois eles permitem-nos analisar esquematicamente os grandes eixos do seu filosofar. Digamos desde já que muito longe de querer limitar o problema do sentido a um subjetivismo cómodo e construtivista ou a uma filosofia mal definida, porque concebida a reboque da ciência, M. Baptista Pereira faz dela uma força envolvente que, apesar de pertencer sempre à intimidade de qualquer homem, o transcende sempre.

Duas experiências originais e irredutíveis, diz-nos, entreteceram, pelo cunho epocal que deixaram, "o torráo do pensamento filosófico europeu: a experiência grega da physis e a bíblica de tempo. Se do primeiro tipo de experiência herdamos, como traço dominante, o conceito de archê ou origem absoluta e princípio dinâmico de todas as coisas, o segundo transmitiu-nos, com particular incidência, a ideia de movimento e de advento de um sentido irreversível que desperta, de modos sempre diferentes, a surpresa e a esperança, a responsabilidade e a seriedade da nossa existência» ${ }^{6}$.

Interessado sobretudo na experiência bíblica de tempo e na sua riqueza para a meditação filosófica sobre o sentido ou não sentido do existir, é no entanto a densidade das interpretaçóes da origem que Baptista Pereira persegue em todo o seu filosofar, sempre construído em diálogo com grandes filósofos do Ocidente ou com problemas reais aparecidos ao longo da história. É aliás neste contexto, atualmente estranho, do poder ser tocado pela participação hermenêutica num pro-

\footnotetext{
2 Pereira 2000: 3-62; Pereira 2000: 189-259; Pereira 2001: 3-68.

3 Pereira 1995: 357-363.

4 Pereira 1991: 237-243.

5 Pereira 1997: 1-113.

6 Pereira 1997: 3.
} 
blema comum, a que o passado já respondeu (com as suas categorias), que podemos entender o impacto dos gregos, na filosofia de Miguel Baptista Pereira, nomeadamente, de Platão e Aristóteles. Retomando a pergunta de Kurt von Fritz, o professor questiona-se mesmo sobre "O que é que torna os Gregos antigos táo importantes para um autor apaixonadamente comprometido na procura de uma solução para problemas do nosso tempo aparentemente novos e únicos? ( ...). Embora os gregos se tenham debatido entre diferentes e até contraditórias respostas aos problemas suscitados pela razão nascente, jamais deixaram de se ouvir uns aos outros»?

Poder ouvir (ou ler) o outro, perceber que ele pode ter algo a dizer-nos, é para Baptista Pereira uma operação hermenêutica fundamental em que a oferta de sentido atinge o seu objetivo, pois o que é ouvido ou lido é apropriado num processo dinâmico de compreensão, em que o ouvinte ou leitor intervém com horizontes particulares vindos da sua perspetiva histórica. A cadeia formada pelo poeta, pelo intérprete, pelo ouvinte ou leitor representa a articulação do "ato hermenêutico integral" a que se chama hoje "círculo hermenêutico" e a que já o diálogo Íon de Platão chamava «doação divina partilhada por muitas vozes e interpretaçóes» ${ }^{8}$.

A filosofia parte sempre de pressupostos, de um efeito histórico das respostas do passado, que nos permitem retomar, a partir das nossas próprias questóes, a grande questáo que a todos une, logo ela tem na sua origem uma doação cujo correlato é o ouvir um excesso de sentido inesgotável, que é por sua vez a raiz das diferenças históricas que formam a tradição. A procura grega da origem é em Baptista Pereira mediada pelo novo, sendo pois o problema da temporalidade da origem e do fundamento o que o ocupa na tarefa que a si mesmo se impõe: pensar filosoficamente a história da filosofia, contra a tendência para confundir a obra filosófica «com uma banda registadora ou um trabalho de computador tecnicamente imperfeito"'. Distinguir claramente na história da filosofia a fonte documental da fonte origem, eis o seu grande escopo, no diálogo que vai estabelecendo com a tradição, ao longo de toda a sua obra.

\footnotetext{
7 Pereira 1988: 217.

8 Pereira 1995: 371.

9 Pereira 1997: 4-5.
} 
No contexto deste esforço, para contestar a redução da história da filosofia a pura doxografia, surge-lhe inevitavelmente a pergunta pelo essencial do pensamento grego. A dialética socrática da pergunta e da resposta, que define o lugar da finitude humana no universo do sentido, é então reabilitada como originária contra o modelo económico da racionalidade que o primado moderno do método vai instalar na ordem filosófica do sentido. A partir da Modernidade, com efeito, relembremos, a via da dúvida e todo o sistema de regras inerentes ao método passam a ritmar a vida humana e a dar-lhe sentido. É pois contra um modelo de compreensáo do mundo reduzido ao prisma do pensamento calculador que nada recebe e tudo produz, a partir de um grau zero, que Baptista Pereira se insurge. Este modelo, hoje dominante, pensa, esqueceu de tal modo a finitude e o enraizamento no mundo, promoveu a tal ponto a construção, a certeza e a produçáo que hoje já não sabemos nem receber nem perguntar.

É pois a aliança entre o subjectum, palavra que para os gregos referia apenas o fundamento ou a substância que está por baixo de tudo (hypokeímenon), e $o$ eu que o homem diz de si mesmo na Modernidade, que M.B. Pereira contesta radicalmente, na linha da hermenêutica filosófica de M. Heidegger e H-.G. Gadamer. A elevação moderna da razão humana a fundamento é, em sua opinião, absolutamente redutora do sentido originário e acaba por transformar o saber em puro ato de produzir ou fabricar, no contexto da consagração da razão subjetiva, senhora e legisladora da natureza ${ }^{10}$.

$\mathrm{Na}$ raiz desta nova conceção de saber, que dominou o Ocidente desde a nossa modernidade e transformou completamente o próprio projeto epistémico herdado dos gregos, Baptista Pereira deteta uma fuga. Isto é, uma verdadeira rejeição do estar no mundo, acompanhada por uma necessidade vital que passa a ter como agente transformador o nascimento do sujeito e a sua vontade de reconhecimento e confirmação de si como diferente. Esta forma de pensar, lembra-nos, não se assemelha em nada ao sentir-se em casa e ao participar de forma contemplativa, cívica e prática da cidade grega, horizonte que deu origem ao nascimento ético e político do filosofar. O espírito da Antiguidade greco-romana, diz-nos, julgaria como «supremo absurdo transformar o mundo sem primeiro se interrogar sobre o valor ético desta mudança» ${ }^{11}$.

\footnotetext{
10 Pereira 1997: 17.

11 Pereira 1988: 217.
} 
Ora, foi justamente isto o que a modernidade fez, distinguindo-se das outras épocas pelo esquecimento do outro, e pela atitude de desconfiança e suspeita face a todo o recebido. Assim o homem moderno revolucionou as condiçóes da compreensão, passando a entender apenas aquilo que era capaz de produzir por si próprio; promoveu o narcisismo, rejeitando todo o envolvimento com o mundo e, nomeadamente, toda a receção da tradição. Acabou por transformar-se com o decorrer dos tempos no homo faber e animal laborans dos dias de hoje que não sabe já pensar e esquece, de forma quase ingénua, que é pela palavra que ele pode realizar, com outros, o sentido num espaço público de aparição.

É esta profunda redução teórico-técnica do sentido do saber, que marcou todo o Ocidente a partir da modernidade, que Batista Pereira critica veementemente, situando-se assim na linha da análise hermenêutico-gadameriana do facto ciência e suas repercussóes políticas na evolução da Europa ${ }^{12}$. Com efeito, a nova mentalidade, que se iniciou na Filosofia a partir da modernidade, adota uma «visão intermitente do tempo" que parte do princípio de que o passado é algo ultrapassado, concluído e acabado, e esquece como ele age ainda nos projetos históricos do homem, afirmando-se na sua própria negação ${ }^{13}$. Para o nosso filósofo a tradição não pode reduzir-se a um somatório de proposiçôes veiculadas através do tempo, mas é, pelo contrário, entrega e libertação para o que nos é transmitido como realidade originária e a que temos que responder com a nossa diferença histórica ${ }^{14}$. Daí o valor de pensar com os gregos: é preciso retomar a ideia de filosofia, como amor à sabedoria, quando hoje podemos constatar que a aplicação dos conhecimentos científicos a áreas em que está em jogo a compreensão que o homem tem de si mesmo provoca conflitos, faz surgir perplexidades, e entrar em jogo fatores não científicos que defendem os seus direitos. Veja-se nomeadamente o surto das éticas aplicadas e da bioética no nosso mundo contemporâneo ou a própria discussão sobre a importância das humanidades em contextos científicos.

O que é que isto significa filosoficamente? Que a redução moderna da experiência às categorias prévias do sujeito e ainda às suas variantes gnosiológicas entretanto surgidas - a relação sujeito-objeto, a redução da verdade a simples adequaçáo, o esquecimento do fundamento e unidade do mundo,

\footnotetext{
12 Gadamer 1990: 87-105.

13 Pereira 1977: 8.

14 Pereira 1977: 9.
} 
a eliminação de toda a diferença ontológica e transcendência -, acaba por dar origem ao predomínio de uma razão unidimensional e económica que urge completar. Não podemos esquecer que esta racionalidade calculadora, apesar de já contestada pela Fenomenologia e pela Hermenêutica, ainda hoje nos governa. É neste sentido que Baptista Pereira a contesta, pensando como é preciso desconstruí-la, enquanto modelo único, isto é, fazer aparecer justamente o que ela tem abafado, a tradicional imagem de mundo veiculada pela literatura, pela narrativa histórica e pelo mito. É assim que o filósofo de Coimbra recorre por meio da hermenêutica, nomeadamente de Gadamer e Ricoeur, a dimensóes intemporais do horizonte de problematização filosófica que nos foi deixado pelos gregos.

O seu objetivo é uma reeducação do olhar filosófico em ordem a uma defesa do alargamento do sentido da experiência ${ }^{15}$ humana. Com efeito, em sua opinião, a suspeita ou fuga moderna do mundo, partem de uma experiência de penúria radical e transformam-se num perigoso cálculo empobrecedor, cujas consequências dáo origem ao niilismo e à crise económica dos dias de hoje. Caracterizam-se por dar à razáo humana o papel de um legislador que neste mundo apenas reconhece a sua própria virtuosidade, por outras palavras aquilo que sabe fazer. Assim se impôs no Ocidente o império do sujeito moderno, monológico, narcísico, que muito rapidamente passou da "utilizaçáo do mundo à fabricação do ser vivo", com todas as ameaças, promessas e perplexidades que esta possibilidade hoje encerra.

Ora, ao narcicismo moderno- causador de crise, porquanto no mundo o sujeito quer apenas confirmar os seus dotes, transformando-o num estaleiro onde confirma o seu próprio reconhecimento- Batista Pereira contrapóe, na linha da hermenêutica de Gadamer, o valor de uma receçáo da questáo originária que motivou a tradiçâao. Esta deve chegar-nos, em sua opiniâo, nomeadamente em momentos de crise, como horizonte de possibilidades a que devemos responder a partir da nossa diferença histórica, apropriandoa e modificando-a ${ }^{16}$. É assim que ganha relevo na sua filosofia a tarefa de recuperar os gregos, contra a ameaça da redução moderna e tecnológica dos possíveis da existência humana. É preciso nomeadamente recuperar, contra o modelo cartesiano, o conceito grego de método, como caminho e diálogo aberto à novidade do mundo.

Com efeito, o método moderno, ao sacrificar a novidade da experiência, estreitou o horizonte dos possíveis humanos, reduzindo-os ao âmbito

\footnotetext{
15 Pereira 1977: 10 sqq.

16 Pereira 1977: 9.
} 
do puramente empírico e palpável; marcou assim uma orientação exclusiva para o facto, para o positivo, o certo e seguro. E conseguiu-o à custa da fixação do sentido de uma experiência cuja repetição e verificabilidade estariam asseguradas ${ }^{17}$ apenas no laboratório.

Neste novo contexto, o que se considerou ser verdade só podia ser entendido contra a ordem temporal e quotidiana do estar no mundo. A razão moderna, técnica e económica, resultante da grande desconfiança face ao mundo- veja-se a dúvida metódica de Descartes - operou com efeito uma real transformação da nossa própria imagem de mundo. Simultaneamente, inventou um conceito de saber que na sua essência é entendido como saber para poder, prever e dominar, isto é, como um fazer e transformar. É este o modelo que Baptista Pereira rejeita, como originário, pois, nele perde-se o sentido e a densidade fundamental do receber, próprio de uma dimensão da razão humana ainda familiar aos gregos e que se encontra nomeadamente na experiência do exaiphnês da carta VII de Platáo, 341 c-d, e no Parménides, 156 c-e. Nos dois casos, fazer a experiência de algo significava ainda que algo nos sucede e atinge, derruba e sobretudo transforma, mudando perspetivas e formando interiormente.

É esta formaçáo interior do ser humano que começa a perder-se na Modernidade, perante o entusiasmo da transformação operatória do mundo que interessa ao pensamento filosófico de M. Baptista Pereira. Digamos pois que a ciência objetiva do mundo moderno parte de pressupostos quanto ao sentido da vida e do homem que Batista Pereira não partilha. Em vez de "entes", diz-nos o professor, «aparecem agora os "objetos" e o lugar do eidos (termo grego) clássico, de sentido predominantemente ontológico, é ocupado agora pela lei de constituição dos objetos no campo de representaçáo da consciência (...). Do real nada mais interessa para além de determinados aspetos, que, à maneira de casos individuais, caem sob o horizonte ou lei $a$ priori projetada pelo sujeito cognoscente» ${ }^{18}$. Nem o poético nem o literário, muito menos o trágico e seus mythoi são agora considerados como fonte de conhecimento ou formação. Com efeito, a formação que agora interessa é a metódica e calculadora, ou a positiva e operativa. Assim é abandonada a cultura da interioridade humana, tradicionalmente ligada à transmissão, à Ética em sentido socrático e aristotélico e em suma às humanidades.

\footnotetext{
17 Pereira 1977: 10.

18 Pereira 1977: 16-17.
} 
É claro que o espírito metódico da modernidade, pensa no entanto o filósofo de Coimbra, teve a sua importância no desenvolvimento do Ocidente e grandes vantagens: tecendo a sua complicada trama da planificaçáo, ele permitiu o progresso, o desenvolvimento, apurou extraordinariamente a ciência e esta trouxe ao mundo com a técnica, sua aliada, grande esperança e qualidade de vida. Mas ele deixou de lado como não significativas dimensôes autónomas da realidade, que fazem parte do horizonte de sentido do ser humano e que já os gregos detetavam como essenciais na sua relação vivida com o mundo.

Foram os gregos, diz-nos, citando Hegel, os primeiros a fazer do mundo a sua casa ${ }^{19}$. E sublinha: já Hegel situa o "gérmen da liberdade que pensa e a necessidade do nascimento da Filosofia entre os gregos, precisamente no torrấo da "Heimatlichkeit» existente no espírito do estarna-intimidade de si mesmo", representado objetivamente na existência física, civil, jurídica, moral e política, «neste caráter da historicidade bela, livre pela qual aquilo que eles (os Gregos) são, está também neles como Mnemosyne $»^{20}$.

Com esta valorização da familiaridade dos gregos com o ser, não reduzido ainda à natureza mecânica dos modernos, Baptista Pereira quer preparar para a Filosofia as condiçóes de um novo tempo pleno, começando por interrogar a essência da linguagem e, na esteira da sua filiaçáo bíblica, a natureza recetiva e auditiva da nossa relação primordial à linguagem. Desde Heraclito a Heidegger, lembra-nos, "perpassam através da densa cortina dos séculos testemunhos do primado do apelo, fundamento do falar e do responder humanos, convencendo-nos de que o núcleo mais íntimo do pensar é ouvir ${ }^{21}$.

Interpelação fundamental, espanto, diálogo da alma consigo mesma, eis os modos de pensar ainda não submetidos ao primado de uma relação meramente calculadora com o mundo pela qual se caracterizou o filosofar da modernidade. Neles se expressa uma mediação linguageira do sentido que a modernidade propositadamente descuidou, em prol do primado filosófico de uma outra linguagem: a matemática, rigorosa e artificial. Ora, é hoje

\footnotetext{
19 Pereira 1977: 27.

20 Hegel, G. W. F., Vorlesung uber die Geschichte der Philosophie, Ausg., Moldenhauer - Michel, K. M. (1971) I. Frankfurt, apud Pereira 1997: 27.

21 Pereira 1997: 60.
} 
na hermenêutica filosófica, corrente de pensamento que B. Pereira faz sua, que se reativa justamente uma certa tradição grega, reprimida, que acentua o primado da palavra "quando em vez do ponto de partida do "cogito", da consciência psíquica ou intencional e dos factos extra linguísticos, se apela para o mundo aberto pela linguagem natural, mundo da pré-reflexão e da pré-compreensão, o "mundo da vida", cuja densidade originária e nova muito nos dá que pensar»" ${ }^{22}$.

Como iremos ver, são justamente as raízes gregas desta Hermenêutica que o filósofo português quer reabilitar, nomeadamente, na sua reflexão sobre o diálogo Ion de Platão, feita no texto «Platão e a Hermenêutica Filosófica $»^{23}$.

III-

O sentido da vida é antes de mais uma capacidade vivida de sentir, de receber e gozar a vida e não uma pura construção. Os gregos já mostraram que tal capacidade se atesta através da linguagem ordinária, embora nesta não se esgote toda a experiência do sentido. Hoje a redescoberta hermenêutica desta linguagem dá-lhes razão e pode resumir-se deste modo: existe para nós uma verdade que nada tem de científico na aceção moderna deste termo, uma verdade que encontramos justamente por meio dos enredos que nos chegam, da narrativa histórica, do trágico e das histórias que contamos sobre nós. E nenhum discurso científico pode substituir-se a este tipo de encontro hermenêutico com uma ordenação do mundo e sua verdade. $\mathrm{Na}$ sua origem diz-nos Gadamer: «o problema hermenêutico da compreensão não é de modo algum um problema metódico. Não se interessa por um método de compreensão que permita submeter os textos ao conhecimento científico, tal como acontece a qualquer outro objeto da experiência. Nem sequer se ocupa basicamente em constituir um conhecimento seguro e de acordo com o ideal metódico da ciência. E, no entanto, trata-se nela de ciência e também de verdade. Quando se compreende a tradição, não só se compreendem textos, mas também se adquirem perspetivas e se conhecem

\footnotetext{
22 Pereira 1999: 323.

23 Pereira 1995: 357-363.
} 
verdades $\aleph^{24}$. Percebe-se, ao fim e ao cabo, aquilo de que se trata na experiência ética que nos envolve e ainda a própria expressividade do político.

Exposto ainda ao efeito dos mitos transmitidos pelos poetas e declamados pelos rapsodos, Platão traçou assim no diálogo Íon, lembra-nos Baptista Pereira, as bases de uma interpretação que apresenta em embriáo o primeiro esquema de uma Hermenêutica. Neste diálogo Baptista Pereira valoriza nomeadamente a metáfora da pedra magnética, usada por Sócrates, para explicar os elos da receção, da declamação e da interpretação poética. Esta metáfora mostra, de forma muito clara, que não é por meio de uma qualquer técnica que nasce o poema, a declamação e a interpretação. Mas sim mediante uma cadeia de pertença, de inspiração e de efeito histórico ${ }^{25}$ que se estabelece mediante a linguagem natural. «Sem inspiração, sem estar fora de si e para além da razão, o poeta não está em estado de criar poesia nem consultar oráculos». «Íon confessa que os seus olhos ficam rasos de lágrimas quando recita algum texto patético, os seus cabelos se erguem de medo e o coração começa a bater quando a cena declamada for aterrorizadora. Uma vez que o rapsodo desperta no público estes mesmos efeitos, o espetador é o último elo da cadeia magnética por onde passa a mensagem». E à pergunta insistente, sobre o campo de conhecimento que, fora da ciência e da técnica, distingue o rapsodo, Ion aponta a linguagem natural.

Em resumo, foi Platão que abriu o campo das múltiplas interpretaçóes dos poetas, protagonizado pelo talento dos rapsodos, ao mostrar através de Íon que existe uma verdade que resiste à abordagem científica e económica, verdade essa que começa na interpretação originária do poeta, continua na interpretação segunda do rapsodo e termina na apropriação de ouvinte ou leitor, que modifica ${ }^{26}$. Neste sentido diz-nos Baptista Pereira, "o vínculo de Platáo ao diálogo náo se deveria dissolver, pois ele jamais foi totalmente eleata, não defendeu uma ontologia de dois mundos e permaneceu " socrático", isto é um pensador consciente dos limites do saber humano vividos na sua profunda convicção religiosa, crítico da ambição do "saber técnico" dos seus adversários e defensor do diálogo como método da filosofia» ${ }^{27}$. Ser em diálogo significa «ser para além de si, pensar o outro e regressar a si como

\footnotetext{
24 Gadamer 1986: 1

25 Pereira 1995: 369.

26 Pereira 1995: 369 .

27 Pereira 1995: 371
} 
um outro ${ }^{28}$. Si mesmo como um outro, eis uma nova maneira de pensar a própria subjetividade a partir de uma noção de verdade que excede a verificabilidade e exatidão dos modernos.

É a substância socrática do pensamento de Platão e de todo o pensamento helénico que M. Baptista Pereira neste sentido valoriza e, tal como Gadamer, discute a leitura fisiológica, habitualmente feita, dos começos da Filosofia grega. «Não foi o tema da Natureza mas o dos múltiplos extravios do homem que se constitui objeto da Filosofia dos primeiros pensadores e não passa de ingenuidade hermenêutica interpretar o poema de Parménides em sentido ontológico $»^{29}$.

O que Baptista Pereira aprecia neste núcleo socrático da filosofia grega é a desilusão de Sócrates perante a Filosofia da natureza, tal como a verdadeira raiz da sua pergunta pelo bem e pelo sentido da praxis. Considera, no entanto, que a pergunta socrática pela virtude e pelo bem ficou submersa sob a construção aristotélica de um platonismo ontológico cindido em dois mundos e, por isso, considera com Gadamer que o verdadeiro sucessor do socratismo teria sido o Aristóteles da Ética ${ }^{30}$. «A procura do meio que anima toda a Ética e Política de Aristóteles é uma resposta da filosofia prática às ameaças da contradição trágica ${ }^{31}$, que acompanha o homem na sua compreensão do ser. Esta forma de meio-termo não anula o homem nem $\mathrm{o}$ mundo, preserva a identidade e as diferenças e constitui o sentido último da catarse trágica que transforma a Poética de Aristóteles num verdadeiro capítulo da Política ${ }^{32}$.

À presença de Aristóteles na formação da Fenomenologia hermenêutica contemporânea, nomeadamente, na de $\mathrm{M}$. Heidegger, dedicou ainda M.Baptista Pereira um outro texto ${ }^{33}$, extraordinariamente rico que analisaremos oportunamente.

\footnotetext{
28 Pereira 1995: 381

29 Pereira 1995: 380

30 Pereira 1995: 380-381.

31 Pereira 1988: 230.

32 Pereira 1988: 231.

33 Pereira 1995a: 481-510.
} 


\section{Bibliografia}

Gadamer, H. G. (1986), Gesammelte Werke, I. Hermeneutik I. Wahrheit und Methode. Grundzugeeiner philosophischen Hermeneutik. Tubingen: Mohr.

Gadamer, H. G. (1990), Das Erbe Europas. Frankfurt: Suhrkamp.

Pereira, M. B. (1977), "Introdução", in Peters, F. E. (ed.), Termos filosóficos gregos. Um léxico histórico. Lisboa: Fundação Calouste Gulbenkian: VI-XXV.

Pereira, M. B. (1988), "Modos de presença da filosofia antiga no pensamento contemporâneo", in As humanidades greco-latinas e a civilização do universal. Actas. Coimbra, Instituto de Estudos Clássicos: 209-310.

Pereira, M. B. (1991), "Sobre o trágico", in Medeia no Drama Antigo e Moderno. Actas. Coimbra, Centro de Estudos Clássicos e Humanísticos, Faculdade de Letras: 237-243.

Pereira, M. B. (1995), "Platão e a hermenêutica filosófica", Miscelânea em honra de Maria Helena Rocha Pereira, Humanitas 47: 357-383.

Pereira, M. B. (1995), “A presença de Aristóteles na génese de Ser e Tempo de M. Heidegger”, Biblos 71: 481-510.

Pereira, M. B. (1997), "Originalidade e novidade em Filosofia. A propósito da experiência e da história”. Homenagem a Victor Matos e Sá, Biblos 53: 1-113.

Pereira, M. B. (1999), "Experiência e sentido”, Miscelânea em honra de Sílvio Lima, Biblos 55: 289-401.

Pereira, M. B. (2000), “O século da hermenêutica filosófica: 1900-2000”, Revista Filosófica de Coimbra 17: 3-62.

Pereira, M. B. (2000), "O século da hermenêutica filosófica: 19000-2000", Revista Filosófica de Coimbra 18: 189-259.

Pereira, M. B. (2001), “O século da hermenêutica filosófica: 19000-2000”, Revista Filosófica de Coimbra 19: 3-68. 


\section{Índice de Autores}

Aguiar, Conde de - 24 n. 12

Albertinus, Aegidius - 71, 81

Emblemata-71, 71 n. 2, 81

Alberto, Paulo Farmhouse - 144

Alcides, Sérgio - 24 n. 11, 66

Alegre, Manuel - 149 n. 3

Almeida, M. Lopes - 171

Almeida, Padre Teodoro de - 34 n. 25

Almodóvar, Pedro - 178

Alvarenga, Lídia - 81

Alvarenga, Manoel Ignácio da Silva - 22, 27 n. 20

Anacreonte - 25

Anaximandro - 89

Andrade, Eugénio

As Mãos e os Frutos - 91 n. 7

Andrade, Francisco de - 165 n. 11, 171

André, Carlos - 163 n. 1, 164 n. 4, 170 n. 23,171

Apolónio de Rodes - 25

Ariosto, Ludovico - 61 n. 62

Aristófanes - 236, 239

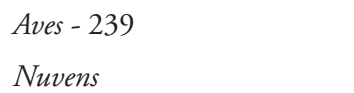

60-67-239 n. 8

Paz- 239

Rãs -236

1058-1061 - 236

Aristóteles - 15-68, 73, 77, 78, 105, 137, 182 n. 15, 194, 210, 244, 245, 260, 268, 281, 289, 290
Categorias - 12-13, 15-68, 78

3 b $20-55$

$3 \mathrm{~b} 22-55$

5 b $12-55$

Organon - 55 n. 53, 65

Peri Hermeneías (De interpretatione) - 59,

77,78

Poética - 194, 210, 246, 260, 268, 289

$1447^{\mathrm{a}}-1456^{\mathrm{a}}-194$ n. 14

$1450^{\mathrm{a}}-195$ n. 16

$1450^{\text {a }} 8-10$ - 244 n. 14

$1450^{a} 39-1450$ b $18-244$ n. 14

1450 b - 195 n. 17

1450b 21 sqq. -245 n. 15

1450 b 31 sqq. -245 n. 15

$1451^{a}-195$ n. 17

$1451 \mathrm{~b}-205$ n. 44

$1452^{a}-203$ n. 36,204 n. 40,268

1452a 57 - 205 n. 42

$1452 b-195$ n. 15

$1453^{a}-196$ nn. 18,19

1453 b - 200 n. 27

$1454^{\mathrm{a}} 35-182$ n. 15

1455 b - 195 n. 17

Política-289

$1253^{a}-148$

$1331^{\mathrm{a}} 27-55$

Primeiros Analiticos - 59

Retórica

$1354^{a} 3-55$ 


\begin{tabular}{|c|c|}
\hline Arnault, Antoine - 30, 46 & I. $58-153$ n. 15 \\
\hline Grammaire Générale et Raisonnée de Port- & I. $61-153$ n. 15 \\
\hline- Royal -30 & I. $62-153$ n. 15 \\
\hline Logique et l'Art de penser - 30 & Nobre Arquitectura - 159 \\
\hline Arnaut, António - 12, 145-159 & Outros Sinais - 149-159 \\
\hline Alfabeto Intimo e outros Poemas - 159 & II. $1-156$ n. 18 \\
\hline Introdução à Maçonaria - 159 & II. 4 - 153 n. 15 \\
\hline Miniaturais - 149-159 & II. $5-153$ n. 15 \\
\hline I. $2-150$ n. 7 & II. $8-153$ n. 15 \\
\hline I. $3-158$ n. 23 & II. $9-153$ n. 15 \\
\hline I. $4-153$ n. 15 & II.14 - 158 \\
\hline I. $5-153$ n. 15 & II. $16-153$ n. 15 \\
\hline I.6 - 153 n. 15 & II. 18 - 157 n. 20 \\
\hline I.7 - 150 n. 7,153 n. 15 & II. 20 - 156 \\
\hline I. $8-153$ n. 15 & II. $21-153$ n. 15 \\
\hline I. $10-153$ n. 15 & II. $23-153$ n. 15 \\
\hline I. $11-153$ n. 15 & II. $24-153$ n. 15 \\
\hline I. $12-153$ n. 15 & II. $25-153$ n. 15 \\
\hline I. $13-153$ n. 15 & II. $25.1-150$ n. 7 \\
\hline I. $14-153$ n. 15 & II. $25.3-150$ n. 7 \\
\hline I. $15-153$ n. 15 & II. $27-153$ \\
\hline $1.18-153$ n. 15 & II. 28 - 153 n. 15 \\
\hline I. $21-153$ n. 15 & II. $31-153$ n. 15,155 \\
\hline I. $23-153$ n. 15 & II. $34-153$ n. 15 \\
\hline I. $30-153$ n. 15 & II. $35-153$ n. 15 \\
\hline I. $34-153$ n. 15 & II. $38-153$ n. 15 \\
\hline I. $37-153$ n. 15 & II. $40-154$ \\
\hline I. $38-153$ n. 15 & II. $41-153$ n. 15 \\
\hline I. $39-153$ n. 15 & II. 42 - 153 n. 15 \\
\hline I. $44-153$ n. 15 & Recolha Poética - 159 \\
\hline I. $45-153$ n. 15 & Arquimedes -25 \\
\hline I. $48-153$ n. 15 & Assunção, Teodoro T. - 67 \\
\hline $1.49-153$ n. 15 & Aubenque, Pierre - 65 \\
\hline $1.51-153$ n. 15 & Azevedo, António Araújo (Conde da Barca) \\
\hline I. $52-153$ n. 15 & -20 n. 4,34 n. 25 \\
\hline
\end{tabular}


Bacelar, Bernardo de Lima e Mello - 30, 30 n. 23,64

Grammatica philosophica e orthographica racional da Lingua Portugueza - 30, 64

Báez, Fernando - 73 n. 5, 81

Baptista, José Manuel Dias - 189 n. 4, 210

Barbosa, Jerônimo Soares - 33, 33 n. 23, 34 n. 24,64

Gramática Filosófica da Lingua Portuguesa - 33, 33 n. 23, 34, 34 n. 24, 64

Barbosa, João Soares - 66

Barbosa, Tereza Virgínia - 254

Barreto, Lívia Lindóia Paes - 228

Barros, Domingos Borges de - 22

Barros, João de - 164

Bastos, Fernando - 85 n. 1, 97

Battles, Matthews - 73 n. 5, 81

Beau, Albin Éduard - 167 n. 18, 171

Bekker, Immanuel - 55 n. 51, 65

Bíblia Sagrada - 238 n. 7

Bloom, Harold - 191 n. 8, 210

Bodéus, Richard - 57 n. 54, 59 n. 58, 65

Boécio, Anício Mânlio - 78

Bons, Jeroen A. E. - 236 n. 6, 254

Bordes, Jacqueline - 18 n. 1, 66

Borges, Paulo - 85 n. 1, 97

Branco, Camilo Castelo - 259

Brandão, Raúl - 189

As ilhas desconhecidas - 189

Brunschwig, Jacques - 59 n. 58, 65

Bubon, Jacob - 55

Cabedo, António de - 164 n. 7

Cabedo, Miguel de - 164 n. 7

Cairus, Henrique - 130

Calafate, Pedro - 97
Câmara Cascudo, Luiz da - 13, 99-110 Epicuro. Do prazer sem os sentidos - 101 Prelúdio e Fuga do Real-13, 101, 110

Camargo, Ana Maria de Almeida - 24 n. 11

Camargo, António - 24

Camões, Luís de - 135, 164, 167, 168, 190 nn. 6, 7, 248, 259

Os Lusiadas - 164, 164 n. 6, 168, 248

Canto I - 168

1. 3. $5 .-164$ n. 3

1. 3. 7-8 - 164 n. 6

3. $21.5-7-167$

10. $145-248$

Camus, Albert -180, 180 n. 9

Candido, António - 27 n. 20, 66

Canfora, Luciano - 66

Canijo, João - 173-184

Ganhar a vida -178

Mal nascida-178, 178 n. 4

Noite escura -173-184

Cantarella, Raffaele - 130

Cardoso, Maria Judite - 190 n. 6, 191 n. 7, 210

Carvalho, Laerte Ramos de -42 n. 34, 66

Carvalho, Mário de - 12, 231-254

Fantasia para dois coronéis e uma piscina229-254

p. $11-233$

p. $12-233$

p. $13-234$

p. $14-239$

p. $15-244$

p. $16-245$

p. $17-247$

p. $20-247,248$

p. $23-249$ 
p. $23-24-249$

p. $26-234$

p. $28-236,250$

p. $29-237$

p. $30-238$

p. $35-252$

p. $45-239$

p. $60-61-246$

p. $61-248$

p. $61-62-240$

p. $67-238$

p. $81-82-239$

p. $82-236,251$

p. $120-121-240$

p. $126-251$

p. $146-249$

p. $156-242$

p. $184-238$

p. $222-253$

p. $227-248$

O livro grande de Tebas, Navio e Mariana -242 n. 11

Casaubon, Isaac -40 n. 30, 55, 55 nn. 52, 53,57 n. 54, 65, 67

Cassavetes, John - 178

Castro, Ferreira de - 189 n. 5

Castro, José Bernardes - 22

Cataldi, Silvio - 18 n. 1, 66

Catulo - 164

64.47 sqq. -169

64. 305 sqq. -167

Chartier, Roger - 73 n. 11, 81

Chevalier, Jean - 167 n. 16, 171

Cícero, Marco Túlio - 25, 61 n. 62

Claudiano - 164
Coelho, Jacinto do Prado - 257, 257 n. 1, 275

Colli, Giorgio - 65

Combe, Pierre Judet de la - 118 n. 16, 130

Condillac, Étienne Bonnot de - 47

Corcella, Aldo - 66

Corneille, Pierre - 61 n. 62

Corno, Dario del - 130

Corpus Hippocraticum - 61-62

Correia, Natália - 147

Correio Braziliense - 45, 45 n. 38, 59, 60

Corte, Marcel de - 65

Costa, Dalila Pereira da -85 n. 1, 97

Costa, Hipólito da - 45, 45 n. 38, 59, 60

Costa, J. Cruz - 66

Costa, Manuel da - 12, 161-172

Carme Heróico sobre as Núpcias de João e Joana (Proteu) - 165-171

$1-4-165$

$155-165$

Coutinho, Rodrigo de Sousa (Conde de Linhares) - 22 n. 10

Couto, Manuel Amor - 34 n. 24, 66

Coxito, Amândio - 66

Crisipo - 33

Cruz, Isabel - 66

Cuter, João Vergílio Gallerni - 81

Damásio, Joaquim - 43 n. 37

Dante, Alighieri - 191, 259

Demóstenes - 25, 61 n. 62

Denooz, Joseph - 65

Descartes, René - 285

Devereux, George - 252 n. 19, 254

Diário do Rio de Janeiro - 19

Dias, Geraldo Coelho - 72 n. 4, 81 
Diegues Júnior, Manuel - 68

Dodds, Eric Robertson - 151 nn. 8, 9, 159, 199 n. 25, 210

Dostoiewski, Fiódor - 94

Dumoulin, Bertrand - 59 n. 58, 65

Düring, Ingemar - 65

Edmundo, Luiz - 43 n. 37

Edwards, S. F. -67

Ehrenberg, Victor - 18 n. 1, 66

Eichler, August W. - 214

Empédocles - 151, 152, 152 n. 13, 153

Purificaçōes - 151

Sobre a natureza - 151

DK 31 A1 - 151 nn. 11, 12

DK $22-152$ n. 14

Epicuro - 13, 99-110

Carta a Meneceu - 104

Máximas Principais - 104

Sentenças Vaticanas - 104

Erasmo de Roterdam - 104

Espinosa, Baruch - 218

Ésquilo - 19, 20, 236, 237, 254, 263

Agamémnon - 263

Coéforas -179

Oresteia - 178

Prometeu Acorrentado - 19, 20

Estácio - 164

Siluae

$$
\begin{aligned}
& 1.229-170 \\
& 1.239-170
\end{aligned}
$$

Eurípides - 111-130, 165, 181, 182, 236, 250 n. 15

Electra- 179

Ifigénia em Aulide - 178, 181, 182

$$
\begin{aligned}
& \text { 231-302-168 n. } 20 \\
& 731-179 \text { n. } 5 \\
& \text { Ín- } 249 \text { n. } 17 \\
& \text { 82-85- } 249 \text { n. } 17 \\
& \text { 83-84-250 n. } 17 \\
& \text { 84- } 85 \text { - } 250 \text { n. } 17 \\
& \text { Medeia-111-130 } \\
& \text { 39-40 - } 121 \text { n. } 24 \\
& \text { 44-45-121 n. } 24 \\
& 79-129,129 \text { n. } 55 \\
& \text { 85-88 - } 115 \text { n. } 10 \\
& 88-115 \text { n. } 9 \\
& 92-122 \text { n. } 28 \\
& \text { 93-95-121 n. } 24 \\
& \text { 103-105- } 121 \text { n. } 24 \\
& 168-121 \text { n. } 23 \\
& \text { 174-175 - } 121 \text { n. } 24 \\
& 187-122 \text { n. } 30 \\
& 188-122 \text { n. } 29 \\
& 230 \text { - } 119 \text { n. } 19 \\
& 250 \text { - } 119 \text { n. } 19 \\
& 255-128 \text { n. } 53 \\
& 309-117 \text { n. } 14 \\
& \text { 315- } 117 \text { n. } 14 \\
& 348-117 \text { n. } 14 \\
& \text { 407-409 - } 119 \text { n. } 19,123 \text { n. } 35 \\
& \text { 448-450 - } 118 \text { n. } 15 \\
& \text { 455-458-118 n. } 15 \\
& \text { 535-539- } 119 \text { n. } 21,122 \text { n. } 27 \\
& \text { 573-575-119 n. } 19 \\
& 591-119 \text { n. } 20 \\
& \text { 593-597 - } 118 \text { n. } 17 \\
& \text { 610-611 - } 118 \text { n. } 17 \\
& 622-118 \text { n. } 15 \\
& 700-115 \text { n. } 8
\end{aligned}
$$




\section{ÍNDICE DE Autores}

$880-881-128$ n. 54

$1077-1080-121$ n. 26

1330 - 119 n. 20

1336-1343- 119 n. 21

$1339-123$ n. 34

$1342-122$ n. 32

$1343-122$ n. 31

1358-1368- 120 n. 22

$1407-122$ n. 33

Ferreira, António - 164, 165, 165 n. 10, 166 n. 14

Aos bons engenhos - 25 n. 15

Arquigâmia-165 n. 10, 166 n. 14

Ode

$$
1.2-165 \text { n. } 10
$$

\section{Soneto}

$$
2.17-165 \text { n. } 10
$$

Ferreira, David Mourão - 188

Ferreira, Silvestre Pinheiro - 12, 15-68

Breves observaçōes sobre a constituição politica ... -64

Cartas sobre a Revolução do Brasil - $21 \mathrm{n}$. 7, 61, 64

Categorias, tradução de Aristóteles - 1213, 15-68

Divisão do Império do Brasil em cinco monarquias confederadas - 64

Essai sur le psychologie - 21 n. 8, 63

Gramática Filosófica - 17

Ideias politicas - 64

Manual do cidadão em um Governo Representativo - 21 n. 8, 49, 61, 64

Memória sobre um novo princípio da Teórica do Calórico - 17, 30, 36, 37, 39

Memórias e cartas biográficas ... $-21 \mathrm{n} .7$

Memórias politicas sobre os abusos gerais ... -21, 21 n. 6, 41, 61, 63

Noções elementares de Filosofia geral e aplicada ... -46 n. 40, 64

Observaçôes sobre a Carta Constitucional do Reino de Portugal ... - 21 n. 6, 63

Observaçôes sobre a Constituição do Império do Brasil ... - 49, 61, 64

Precis d'un cours de philosophie élémentaire -64

Preleções Filosóficas - 15-68

Ferreira, Tânia Maria - 22 n. 10, 66

Ferreira, Vergílio - 12, 131-144

Alegria Breve - 139, 143 n. 23, 144

p. $156-139$ n. 11

Aparição - 136, 138, 144

p. $44-137,137$ n. $7,138,138$ n. 9

p. $129-139$ n. 12

p. $145-138-139,138$ n. 10

p. $193-136-137,136$ n. 6, 137

Até ao Fim-139, 140, 141, 144

p. 118 - 139 n. 13

Espaço do Invisivel-136, 136 n. 5, 144

p. $4-136$ n. 5,137 n. 8

p. $5-139$ n. 14

p. $17-136$ n. 5

p. $17-18-137$ n. 8

p. $127-139$ n. 14

Na tua Face - 140, 141, 144

Para Sempre-138, 144

Pensar-140, 144

p. $11-143$ n. 20

p. $14-140$ n. 17

p. $16-143$ n. 19

p. $127-143$ n. 21

Signo Sinal-139, 144 
p. $46-139-140,139$ n. 16

p. $147-139,139$ n. 15

Fialho, Maria do Céu - 114 n. 1, 135 nn. 2, 3, 139 n. 12, 144

Flores-Jr., Olimar - 67

Foley, Helena - 123, 123 nn. 36, 37, 130

Fonseca, Fernanda Irene - 143 n. 22, 144

Fonseca, Mariano Pereira da -22

Forestier, Georges - 181 n. 12, 184

Foster, Ryan - 219 n. 20, 228

Freud, Hendrika C. -179 n. 6, 184

Freud, Sigmund - 179

Fritz, Kurt von - 281

Gadamer, Hans-Georg - 134, 279, 282, 283 n. $12,284,287,288$ n. 24, 289, 290

Gagarin, Michael - 234 n. 4, 254

Gagnebin, Jeanne-Marie - 124 n. 38, 130

Galvão, Franklin Ramiz - 64

Garat, Dominique-Joseph - 64

Garcia, José Martins - 188

Garcia, Rodolfo - 43 n. 37, 45, 45 n. 39

Garrett, Almeida - 190 n. 6, 259

Gavilanes Laso, José Luís - 143 n. 23, 144

Gazeta do Rio de Janeiro - 42, 43

Genovesi, Antonio - 34 n. 25

Gesner, Konrad - 73, 73 n. 10, 81

Gheerbrant, Alain - 167 n. 16, 171

Giard, Luce - 65

Godinho, Helder - 138 n. 9, 144

Goethe, Johann Wolfgang von - 215, 216, 217, 218, 218 nn. 13, 16, 220, 227, 228, 259

Fausto - 218

Metamorfose das plantas - 218
Gonçalves, Maria Filomena - 34 n. 24, 66, 67

Gondikas, Myrto - 118 n. 16, 130

Gonzaga, Tomás António - 26

Lira inédita - 26

Górgias - 236 n. 6

Goulart, Rosa Maria - 136 n. 4, 144

Grouchy, Nicolas de - 55

Graça, Leonor - 81

Guerra, Artur - 171

Guimarães, Manuel Ferreira de Araújo - 22

Guimarães, Manuel Luís Salgado - $24 \mathrm{n}$. 11, 26 nn. 16, 17, 41 n. 32, 66

Guisot, François - 262

Hegel, Georg Wilhelm F. - 94, 134, 286, 286 n. 20

Heidegger, Martin - 134, 142, 282, 286, 289, 290

Heraclito - 223, 286

Fragmento 1 - 92

Herculano, Alexandre - 259

Heródoto - 209

$1.32-33-250$ n. 18

Hesíodo - 150, 165

Teogonia-95

26-28 - 150, 150 n. 7

Himmelmann, Nikolaus - 134 n. 1, 144

Hipócrates

Aforismos

1. 1 - 17

Hodgson, Pierre - 178

Hoisel, Evelina - 188 n. 2, 210

Holanda, Francisco Buarque de - 111-130

Gota d'Água - 13, 111-130

$39-125$ n. 41 


\section{Índice de Autores}

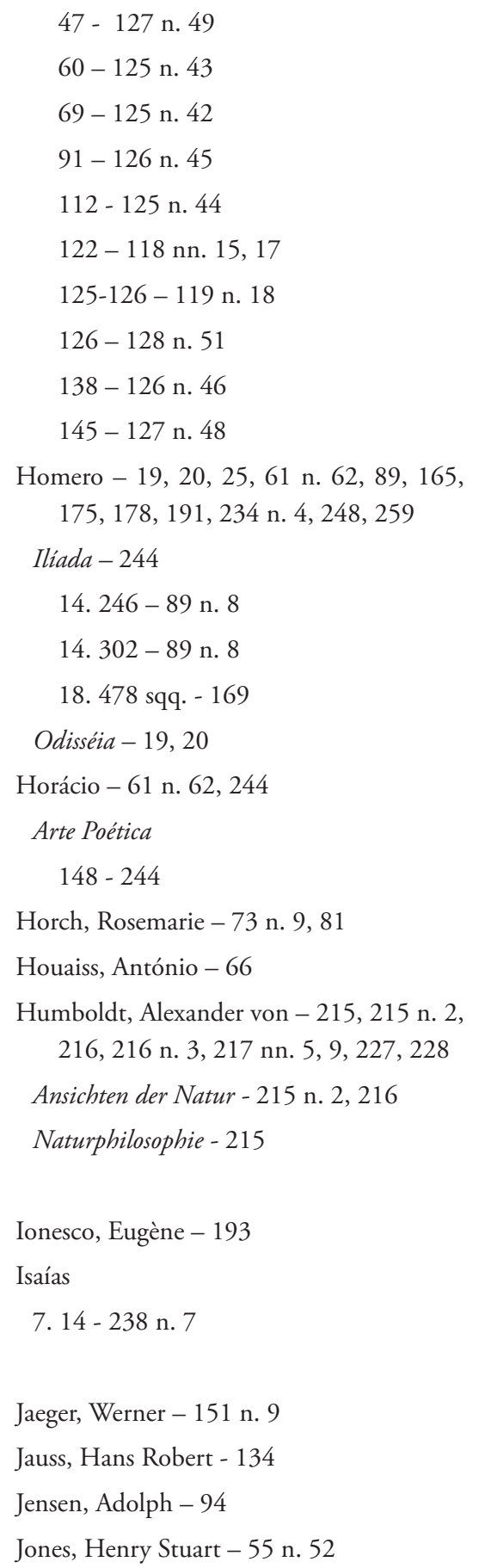

Joyce, James - 259

Jung, Carl Gustav - 179

Junqueira, Celina - 21 n. 6

Keith, Henry - 67

Kirk, Geoffrey S. - 151 nn. 8, 10, 12, 159

Klopstock, Friedrich G. - 61 n. 62

Kneale, Martha - 78

Kneale, William - 78

Knox, Bernard - 123, 130

Kristeller, Paul - 67

Kury, Lorelai - 24 n. 11, 26 n. 16, 66

Laércio, Diógenes - 33, 102, 104, 106, 110

Vidas e Doutrinas dos Filosofos Ilustres - 110

8. 60-61; DK 31 A1 - 151 n. 12

8. 67-72; DK 31 A1 - 151 n. 11

$10-102,104$

Lafontaine, Jean de la - 61 n. 62

Lage, Camilo Martins - 22

Lapa, Manuel Rodrigues - 172, 210

Leão, Delfim - 149 n. 4,159

Ledebur, Mayanna von -178

Leigh, Mike - 178

Lepecki, Maria Lúcia - 188, 192, 193 n. 11,210

Lévy, Edmond - 252 n. 19, 254

Liddell, Henry George - 55 n. 52, 67

Lima, Isabel Pires de - 260, 261, 275

Lima, Manuel de Oliveira - 20 n. 4, 24 n. 12,34 n. 25,67

Lima, Sílvio - 290

Lisboa, José Maria - 20, 24 n. 12

Memória da vida pública do Lord Wellington -24 n. 12

Lisboa, Karen Macnow - 214 n. 1, 217 n. 
10, 218 n. 12,219 nn. $18,19,228$

Lóia, Luís - 85 n. 1, 97

Lopes, Ana Cristina Macário - 240 n. 10, 244, 246 n. 16, 254

Lopes, Óscar - 188

Lourenço, Eduardo - 137 n. 8, 142, 142 n. 18,144

Luciano de Samósata - 240

Lucrécio - 102, 104, 110, 220, 221

De rerum natura - 102, 104, 110

Luzes, Pedro - 275

Lyra, Maria de Lourdes Viana - 22 n. 10, 67

Machado, Diogo Barbosa - 168 n. 19, 171

Machado de Assis, Joaquim Maria - 19

Esaú e Jacó - 19

Malraux, André - 137

Manchester, Alan K. - 67

Manguel, Alberto - 71, 81

Mann, Thomas - 259

Manville, Philip Brook - 18 n. 1, 67

Marinho, José - 85

Marques, Susana - 171

Marrocos, Luís Joaquim dos Santos - 43, 43 n. 37,64

Cartas $-43,43$ n. 37,64

Martins, José de Pina - 171

Martins, José Cândido Oliveira - 243 n. 12,254

Martius, Carl Friedrich Phillipp von - 13, 211-228

Tabulae Physiognomicae de Flora Brasiliensis - 13, 213-228

Nova genera et species plantarum brasiliensium -214

Palmae brasiliensis - 218
Reise in Brasilien - 214

Mateus

$1.22-238$ n. 7

15. $34-238$ n. 7

Matheus, Carlos Bento - 228

Matos, Luís de - 164 n. 4, 171

Matos, A. Campos - 269, 275

Mazzari, Marcus Vinicius - 217 n. 10, 218 nn. 11, 13, 14, 15, 17, 228

McNeely, Ian - 73 n. 7, 74 n. 14, 81

Meleagro de Gadara - 19, 19 n. 2

A Primavera - 19

Melitanus, Joannes - 81

Melo, João Crisóstomo de Couto - 33 n. 23, 64

Gramática Filosófica - 33 n. 23, 64

Melo, Laurêncio de - 67

Melville, Herman - 259

Mendes, João Pedro - 163 n. 2, 171

Michel, K. M. - 286 n. 20

Miller, Arthur - 179

Death of a Salesman - 180

The Crucible - 180

Milton, John - 61 n. 62

Minio-Palluelo, Lorenzo - 78

Monteiro, Inês - 177 n. 2

Mora, Carlos de Miguel - 171

Moraes Augusto, Maria das Graças de - 19 n. 3,27 n. $20,67,114$ n. 1

Moraes, Rubens Borba de - 24 nn. 11, 12, 67

Morais, Inácio - 164

Morão, Paula - 144

Morel, Marco - 22 n. 10, 26 n. 16, 67

Motte, Aurore - 65

Mourão, Artur - 67 
Mueller, Melissa - 124, 124 n. 39, 130

Musurillo, Herbert - 130

Nascentes, Antenor - 67

Nava, Pedro - 17, 62

Capitulos de História da Medicina no Brasil $-17,62$

Navarro, Bernabé - 65

Nemésio, Vitorino - 185-210

Canto matinal - 192 n. 9

Mau tempo no canal-185-210

Cap. I, 31 - 205

Cap. I, $34-208$

Cap. II, 41 - 208

Cap. II, $42-205$

Cap. II, 46 - 208

Cap. III, 53 - 198 n. 23

Cap. III, $57-203$ n. 34

Cap. IV, 76 - 208 n. 46

Cap. V, $76-199$ n. 24

Cap. V, 81 - 199 n. 24

Cap. VII, $99-199$ n. 26

Cap. VII, 100 - 200

Cap. VII, 101 - 199

Cap. VII, 102 - 199 n. 26, 200

Cap. IX, $99-197$ n. 21

Cap. IX, 113 - 205 n. 43

Cap. XI, $129-200$ n. 29

Cap. XI, $131-201$

Cap. XI, 132 - 201 n. 30

Cap. XI, 133 - 201 n. 31

Cap. XI, 133-134- 202 n. 32

Cap. XIII, $154-207$

Cap. XIV, 156 - 208 n. 47

Cap. XIV, 158 - 207

Cap. XX, $203-197$ n. 22
Cap. XXII - 202

Cap. XXIII - 202

Cap. XXIII, $273-197$ n. 20

Cap. XXIV, $239-202$ n. 33

Cap. XXIV, 240 - 202 n. 33

Cap. XXIV, $244-203$ n. 35

Cap. XXVI, 357 - 204 n. 41

Cap. XVIII, $185-206$ n. 45

Cap. XXIX, $281-203$ n. 37

Cap. XXX, $288-204$ n. 38

Cap. XXX, 296 - 204 n. 39

Cap. XXXVI, $356-204$

Cap. XXXVII, 388 - 209

Nem toda a noite a vida 192 n. 10

Nicole, Pierre - 30

Logique et l'Art de penser - 30

Nietzche, Friedrich - 94

Oliveira, Maria Lúcia de - 81

Orfeu - 147, 149, 157, 158

Ortigão, Ramalho - 269

Ottoni, Júlio Benedito - 46 n. 40

Paim, António - 43, 43 n. 36, 63, 67

Palemon - 34

Paluello, M. - 65

Parménides - 151, 289

Pascal, Blaise - 192

Pasternak, Boris - 193

Patriota - 15-68

Pattison, Mark - 67

Pedro II, Dom (Pedro de Alcântara) - 19, 47, 214

História da Guerra do Peloponeso, traduçấo de Tucídides - 19, 20 
Odisséia, tradução de Homero - 19, 20

Prometeu acorrentado, tradução de Ésquilo $-19,20$

Pereira, Miguel Baptista - 277-292

Pereira, José Esteves - 63

Pereira, Susana Marques - 252 n. 19, 254

Pernoud, Régine -73 n. 8, 81

Pessoa, Fernando - 187, 190 n. 6

Peters, F. E. - 283, n. 13

Pimentel, Maria Cristina - 144

Píndaro - 191 n. 7, 223

Pires, António Machado - 188, 188 n. 2, 210

Platão - 33, 78, 85, 90, 102, 105, 131-143, 191, 222, 225, 226, 254, 279, 281, 287, 288, 289, 290

Carta VII

$341 \mathrm{c}-\mathrm{d}-285$

Íon-279, 281, 287, 288

Parménides

156 c-e - 285

Teeteto

$155 \mathrm{~d}-225$

Timeu- 222

Plínio - 220

Plutarco

De profecta uirtute $81 \mathrm{e}-157$ n. 22

Pocar, Ervino - 66

Pontes, Paulo (Vicente de Paula Holanda Pontes; vide Holanda, Francisco Buarque de) - 13, 111-130

Pope, Alexander

Ensaio sobre a critica - 24 n. 12

Ensaios moraes - 24 n. 12

Possevino, Antonio - 73, 73 n. 12, 81

Bibliotheca Selecta - 73, 81
Praça, José Joaquim Lopes - 67

Pródico - 105

Protágoras - 33, 105

Proust, Marcel - 259

Queirós, Eça de - 257-275

Capital-269

Cenas da vida portuguesa - 269

Crónicas da vida sentimental - 260

Os Maias - 12, 255-275

Cap. 1 - 262, 263, 263 n. 2

Cap. $2-263$

Cap. $11-264$

Cap. $13-265$

Cap. $14-265$

Cap. $16-266$

Cap. 17 - 262, 272, 273, 274

O Primo Basílio - 269

A tragédia da Rua das Flores - 257, 261, 268-270, 274, 275

Quental, Antero - 189, 190 n. 6

Quevedo, Francisco de-104, 104 n. 8, 110

Quintiliano - 34

Institutio Oratoria

$1,6-34$

Racine, Jean - 61 n. 62

Ramalho, Américo da Costa - 163 n. 1, 164 nn. 5, 6, 7, 167 n. 15,171

Raven, John E. - 151 nn. 8, 10, 12, 159

Reeve, Michael D. - 130

Reis, Carlos - 240 n. 10, 244, 246 n. 16, 254,275

Resende, Garcia de - 206

$O$ Roance que se fez d'alguas mágoas e perdas - 206 
Revista de Portugal - 190

Reyes Gómez, Fermin - 74 n. 13, 81

Ribeiro, Aquilino - 189 n. 5

Ribeiro, Maria de Fátima - 188 n. 2, 210

Ricoeur, Paul - 134, 284

Rizzini, Carlos - 22 n. 11, 24 n. 11, 67

Rocha Pereira, Maria Helena da -150 n. 7 , 151 nn. 8, 10, 152 nn. 13, 14, 157 n. 21, 159, 290

Rodrigues, Cristina - 171

Rodrigues, José Carlos - 46 n. 40

Rodrigues, José Honório - 65

Rodrigues, Nuno Simōes - 164 n. 6, 165 n. 12,171

Ronsard, Pierre de - 191 n. 7

Rosário, Miguel Barbosa do - 228

Ross, William David - 59 n. 58

Rousseau, Jean Jacques - 216

Rutten, Cristian - 59 n. 58, 65

Sá, Victor Matos e - 290

Safo - 164, 192

Sanches, Pedro - 164 n. 7

Sánchez, Clemente - 81

Sánchez-Marín, José Antonio - 165 n. 9, 170,171

Santo, Arnaldo Espírito - 144

Santos, Marcos Martinho - 67

Saraiva, António José - 68

Sarraute, Nathalie - 138

Saturnino, Francisco Luiz - 43, 43 n. 37

Saturnino, José - 22

Scapula, Joannes - 79

Schelling, Friedrich W. J. $-88,88$ n. 6, $90,97,215,216,219,219$ n. 19, 220, 221,227
Da alma no mundo - 219

Schlafman, Léo - 81

Schmitt, Charles - 55 n. 53, 65

Schofield, Malcolm - 151 nn. 8, 10, 12, 159

Scott, Robert - 55 n. 52, 67

Séneca - 220, 221, 222

Senghor, Léopold Sédar - 149 n. 3

Sérgio, António - 68

Serra, José Pedro - 177 n. 3, 184

Serrano Cueto, Antonio - 171

Shakespeare, William - 61 n. 62, 175, 178

Silva, Inocêncio Francisco da -20 n. 4, 34 n. 25,65

Silva, José Bonifácio de Andrada e - 19, 19 n. 2, 22, 22 n. 10, 47

Silva, Maria Beatriz Nizza da -20 nn. 4, 5 , 21 n. 6,68

Silva, Maria de Fátima - 114 n. 1, 242 n. 11,254

Silva, Markus Figueira da - 109 n. 28, 110

Silva, Vicente Ferreira - 97

Simões, Maria João - 239 n. 9, 254

Soares, Nair de Nazaré Castro - 164 n. 8, 165 n. 11,166 n. 13,167 nn. 17,18 , 169 n. 21,170 n. 22,171

Soares, Pedro Maia - 81

Sócrates - 102, 105, 148, 288, 289

Sófocles - 61 n. 62, 134, 192, 198, 227, 260, 261, 267, 273

Antigona-134, 143 n. 23, 227

$332-227$

Electra-179, 179 n. 5

Rei Édipo-198, 257, 259, 260, 261, 267 , 268, 269

1169-1170 - 273

Sólon - 148, 250 n. 18 
Sousa, Américo Guerreiro - 275

Sousa, António Caetano - 168 n. 19, 172

Sousa, Eudoro de - 13, 83-97

História e Mito - 85

Horizonte e Complementaridade - 85, 92

Mitologia - 85

Sempre o Mesmo acerca do Mesmo - 85

Sousa, Francisco Luiz de -190, 210

Sousa, Frei Luís de - 168 n. 19, 172, 190 n. 6

Soveral, Eduardo Abranches - 85 n. 1, 97

Spix, Johann Baptist von - 213, 214, 219, 219 n. 19, 228

Springer, Kalina - 217 nn. 7, 8, 228

Staudacher, Willibald - 89 n. 9, 97

Stockler, Francisco Garção - 22

Strazzeri, Germanus - 17

Stringberg, August - 193

Sucupira, Newton -42 n. 34, 68

Tamen, Miguel - 210

Tasso, Torquato - 61 n. 62

Teive, Diogo de - 164, 165, 165 n. 10, 171

Teócrito - 164

Teodetes -33

Terêncio -61 n. 62

Tito Lívio - 25

Tolstoy, Leo - 193

Torga, Miguel - 187, 189 n. 5

Tracy, Antoine Desttut de - 47

Tucídides - 19, 20, 25

História da Guerra do Peloponeso - 19, 20
Valente, Ana Maria - 210, 245 n. 14, 268

Vasconcelos, Carolina Michaelis de $-46 \mathrm{n}$. 40,51

Vasconcelos, Joaquim - 46 n. 40

Verney, Luís António - 34, 34 n. 25, 65

$O$ verdadeiro método de estudar - 34, 65

Vianna Filho, Oduvaldo -

Vicente, Gil - 190 n. 6

Vieira, Trajano - 115 n. 8, 118 n. 16, 120, 121 nn. 23, 25, 128 n. 52, 129, 130

Virgílio - 165, 192, 259

Eneida - 244

7. $518-165$

Geórgicas

4. 387-389- 165

Vitte, António Carlos - 216 n. 4, 228

Voltaire, François Marie Arouet - 262

Xenófanes - 151

Yunis, Harvey - 233 n. 2, 254

Williams, Raymond - 177 n. 3, 179 n. 7, 180 nn. 8, 9, 10, 11, 181 nn. 13, 14, 182 nn. 16, 17, 183, 183 nn. 18, 19, 184, 193, 193 nn. 12, 13, 193, 194, 200 n. 28,210

Wolverton, Lisa - 73 n. 7, 74 n. 14, 81

Worthington, Ian - 254

Zaidman, Diana - 25 n. 13, 65

Zehnacker, Hubert - 254

Ubertino de Cezara - 104

Urban, Ignatz - 214

Usener, Hermann - 104 
Página deixada propositadamente em branco 


\section{Autores}

Alexandre Schmitt é pesquisador do PRAGMA - Programa de Estudos em Filosofia Antiga - e doutorando em Filosofia junto ao Programa de Pós-Graduação em Lógica e Metafísica da Universidade Federal do Rio de Janeiro. É bacharel em Filosofia e Letras Clássicas com habilitação em Português-Grego e mestre em Filosofia, pela UFRJ; mestre e doutor em Psicologia pela PUC-SP. Suas áreas de interesse são a História da Filosofia Antiga, Platão e a herança platônica; a Recepção dos clássicos gregos no Brasil; a Psicologia Analítica.

Ana Virginia Pinheiro é Professora Adjunta da Escola de Biblioteconomia da Universidade Federal do Estado do Rio de Janeiro (UNIRIO) e Chefe da Divisão de Obras Raras da Biblioteca Nacional do Brasil. Dedica-se, como bibliotecária e docente, à História do Livro e das Bibliotecas, à Biblioteconomia de Livros Raros e a estudos sobre Documentação e Acervos Bibliográficas de Memória.

Delfim Leão é Professor Catedrático do Instituto de Estudos Clássicos e investigador do Centro de Estudos Clássicos e Humanísticos da Universidade de Coimbra. As suas principais áreas de interesse científico são a história antiga, o direito e a teorização política dos Gregos, a pragmática teatral e a escrita romanesca antiga.

Diogo Falcáo Ferrer é Professor Associado com agregação na Faculdade de Letras da Universidade de Coimbra. Tem-se dedicado à docência e investigaçáo sobretudo no âmbito da filosofia clássica alemã e as suas interaçóes com temas e autores de outras proveniências.

Jorge Deserto é Professor Auxiliar da Faculdade de Letras da Universidade do Porto. Como docente e investigador tem-se dedicado particularmente aos estudos de Cultura e Literatura Gregas, com relevância para o teatro.

Maria do Céu Fialho é Professora Catedrática do Instituto de Estudos Clássicos. A sua actividade de investigadora e docente tem-se centrado na língua e literatura grega, e em estudos de teatro clássico, contexto e recepção, bem como de Poética. Trabalha também a obra de Plutarco.

Luisa Severo Buarque de Holanda é Professora de Filosofia Antiga do Departamento de Filosofia e do Programa de Pós-graduaçáo em Filosofia da PUCRIO. Em sua pesquisa, tem-se debruçado sobre a relaçáo entre os diálogos de Platáo e a poesia grega antiga, bem como sobre questóes de filosofia da linguagem na Antiguidade.

Maria Luísa Portocarrero é Professora Catedrática do Departamento de Filosofia, Comunicação e Informação da Faculdade de Letras da Universidade de Coimbra. A sua atividade de investigadora e docente tem-se centrado nas áreas da Fenomenologia Hermenêutica e da Bioética, com particular incidência em filósofos como H.-G.Gadamer e P. Ricoeur. 
Markus Figueira da Silva é Professor Associado IV no Departamento de Filosofia da Universidade Federal do Rio Grande do Norte. A sua atividade docente temse centrado na Filosofia Grega e em estudos de recepção, com ênfase na Filosofia Helenística.

Nuno Simões Rodrigues é Professor da Universidade de Lisboa e tem-se dedicado à História da Cultura Grega e à Política e Sociedade da Roma Antiga.

Susana Hora Marques Pereira é Professora Auxiliar do Instituto de Estudos Clássicos da Faculdade de Letras da Universidade de Coimbra. A sua atividade docente tem-se centrado em disciplinas relacionadas com a cultura/ literatura gregas, com a língua latina, com a metodologia do trabalho científico, com aspetos pedagógico-didáticos do ensino das Línguas e da Cultura/ Literatura Clássicas. O seu trabalho de investigaçáo contempla sobretudo estudos nas áreas de Literatura Grega, Perenidade da Cultura Clássica, Didática das Línguas Clássicas, Literatura Novilatina em Portugal. 
Maria de Fátima Sousa e Silva é Professora Catedrática do Instituto de Estudos Clássicos da Universidade de Coimbra. Desenvolveu, como tese de doutoramento, um estudo sobre a Comédia Grega Antiga (Crítica do teatro na Comédia Grega Antiga), e, desde então, tem prosseguido com investigação nessa área. Publicou já traduções comentadas de nove comédias de Aristófanes, além de um volume com a tradução das peças e dos fragmentos mais significativos de Menandro.

Maria das Graças de Moraes Augusto é Professora Titular no Departamento de Filosofia do Instituto de Filosofia e de Ciências Sociais da Universidade Federal do Rio de Janeiro (UFRJ). A sua investigação sobre História da Filosofia Antiga abrange temas como Platão e a herança platónica, filosofia e conhecimento no pensamento antigo, filosofia e literatura na tradição antiga e recepção dos clássicos gregos no Brasil.

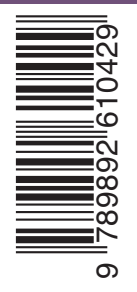


OBRA PUBLICADA

COM A COORDENAÇĀO

CIENTÍFICA
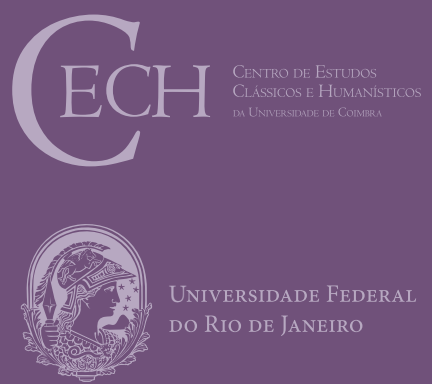

- U 